UNIVERSIDADE DE SÃO PAULO

FACULDADE DE ECONOMIA, ADMINISTRAÇÃO E CONTABILIDADE

DEPARTAMENTO DE ADMINISTRAÇÃO

PROGRAMA DE PÓS-GRADUAÇÃO EM ADMINISTRAÇÃO

BARREIRAS À ADOÇÃO DAS CERTIFICAÇÕES SUSTENTÁVEIS POR PARTE DE EMPRESAS DE BENS DE CONSUMO: UMA PROPOSTA DE SISTEMATIZAÇÃO

Denise de Abreu Sofiatti Dalmarco

Orientador: Prof. Dr. Andres Rodriguez Veloso

SÃO PAULO

2017 
Prof. Dr. Marco Antonio Zago Reitor da Universidade de São Paulo

Prof. Dr. Adalberto Américo Fischmann Diretor da Faculdade de Economia, Administração e Contabilidade

Prof. Dr. Roberto Sbragia

Chefe do Departamento de Administração

Prof. Dr. Moacir de Miranda Oliveira Júnior Coordenador do Programa de Pós-Graduação em Administração 


\section{BARREIRAS À ADOÇÃO DAS CERTIFICAÇÕES SUSTENTÁVEIS POR PARTE DE EMPRESAS DE BENS DE CONSUMO: UMA PROPOSTA DE SISTEMATIZAÇÃO}

Dissertação apresentada ao Programa de Pós-Graduação em Administração do Departamento de Administração da Faculdade de Economia, Administração e Contabilidade da Universidade de São Paulo, como requisito parcial para a obtenção do título de Mestre em Ciências.

Orientador: Prof. Dr. Andres Rodriguez Veloso

Versão corrigida

São Paulo 


\section{FICHA CATALOGRÁFICA}

Elaborada pela Seção de Processamento Técnico do SBD/FEA/USP

Dalmarco, Denise de Abreu Sofiatti.

Barreiras à adoção das certificações sustentáveis por parte de empresas de bens de consumo: uma proposta de sistematização /

Denise de Abreu Sofiatti Dalmarco. -- São Paulo, 2017. $216 \mathrm{p}$.

Dissertação (Mestrado) - Universidade de São Paulo, 2017. Orientador: Andres Rodriguez Veloso.

1. Administração de materiais. 2. Administração de marketing. 3.

Certificações sustentáveis. 4. Barreiras. 5. Sistematização. 6. Stakeholders.

I. Universidade de São Paulo. Faculdade de Economia, Administração e Contabilidade. II. Título. 
Para minha família, minha maior riqueza; e para todos que sonham com um mundo mais sustentável. 



\section{AGRADECIMENTOS}

Que delícia poder chegar neste momento e simplesmente agradecer, de coração e alma, a muitas das pessoas que fizeram esse sonho ser possível. Primeiro gostaria de reconhecer o apoio, fundamental, da minha família. Aos meus pais, Admilson e Elisabete, pela dedicação e esforço para ver a felicidade de seus filhos. Vocês foram, são, e continuarão sendo, eternamente, uma linda referência em minha vida. Obrigada por sempre me mostrar a importância da leitura, dos estudos, da dedicação, e acima de tudo, dos valores, da ética, do bem. Sem o apoio de vocês, incondicional, esse trabalho não seria possível.

Incondicional também é o amor, o apoio, o carinho, o respeito, a admiração e a paciência que sempre encontrei nos olhos, nos gestos e nos braços de meu marido, Leandro. Como foi importante ter seu suporte e motivação, desde o momento em que decidi mudar de rumos na carreira, até os últimos dias, insanos, deste trabalho. Só posso dizer que tudo que faço é para o bem de nós quatro, sempre. E por falar em "nós quatro", como não mencionar minhas duas lindas princesas, Luana e Marina, cujos sorrisos, carinhos, gracinhas e abraços fazem qualquer um se derreter de amores. Vocês são a razão da minha vida e da minha dedicação em estudar e transmitir conhecimentos sobre sustentabilidade, para apoiar, de alguma forma, a construção de um mundo melhor para vocês. Obrigada por me escolherem para ser sua mãe! Vocês fazem meus dias muito mais felizes.

Agradeço também aos meus irmãos, Alexandre e Ricardo, e irmãs, Andrea e Gislaine; aos meus cunhados Patrícia, Daniele, Paulo, Fernando; e aos meus queridos sogros/pais, Amilton e Miralda - pelo carinho, torcida e vibrações pelas minhas conquistas.

Aos meus grandes amigos da vida, Regina, Louise, Kellen, Liliane, Bruno, Cristiane, Diogo, Daniele, André e Michele, vocês são muito especiais e importantes para mim! Agradeço por fazerem parte da minha vida e por estarem sempre dispostos a um papo, um churrasco, um cafezinho - encontros deliciosos que fazem toda a diferença para um dia mais feliz. Também agradeço a torcida e apoio em diversos momentos!

Não poderia deixar de mencionar dois amigos, em especial: Cassio Aoqui, companheiro de aventuras, suporte para crises, inspiração para a vida; e Kavita Hamza, amigona, parceira de gincana, roommate, companheira de artigos e discussões mil sobre sustentabilidade/ consumo sustentável/ mundo melhor e afins, professora da melhor qualidade, super orientadora - você tem mil e uma utilidades! Como é bom ter vocês dois sempre por perto, mesmo que a alguns quilômetros de distância! Obrigada, obrigada, obrigada!!!

Ao meu querido professor orientador, Andres Rodrigues Veloso, por ter me aceitado como sua orientanda, abrindo uma nova página muito importante em minha vida. Você foi um dos inspiradores da mudança... muito obrigada por me ajudar a concretizá-la! Agradeço as suas sugestões durante a caminhada, e também aos momentos da monitoria, que foram muito gratificantes. 
Á querida professora Maria do Carmo Romeiro, pelo carinho e pelos insights transmitidos na etapa de qualificação - sua participação foi muito especial para mim!

Infelizmente não participei tanto quanto gostaria da vida acadêmica nesse período, mas alguns bons amigos que fiz ficarão para sempre guardados no coração: Vitor Nogami, Alexandre Salvador, Sofia Ferraz, Katherine Sresnewsky, David Rodrigues.

Agradeço aos queridos professores da FEA com os quais pude ter um pouco mais de contato durante as aulas - Edson Crescitelli, Marcos Campomar, Ana Ikeda, Bernadete Marinho. Muito obrigada também aos profissionais da FEA, sempre dispostos a ajudar os corações mais aflitos, em especial Dani Ozella, Ivanete, Bianca, Cintia, Cida, Daniela Martins.

A todos aquele me que me apoiaram indicando nomes para conseguir realizar as entrevistas: Thiago Poiani, Ana Helena Ferraz, Davi Gueldini, Denise Nakamura, Renato Wakimoto, Kathy, Ricardo Nery, José Augusto Viveiro, Gabriela Gama, Bruno Bordeaux, Celso Furtado, Fernando Careli de Carvalho, Pedro Dameto, Luiz Fernando Guedes Pinto, Ewerton Nunes, Paulo Renato, Valdir Nascimento. E aos que se disponibilizaram prontamente, mas acabaram não sendo entrevistados: Iguatemi Costa, Melissa Barbosa, Paulo da Mazurky, e Ricardo Mello.

A todos os entrevistados, por disporem de seu tempo para me apoiar neste desafio: Aline Tristão Bernardes, Daniele Rua, Edson Futino, Alfredo Baumbach, Paulo Celso Toledo, Elaine Cristina, Luis Carlos Martini, Flavia Batholomeu, Raquel Badia, Fabiola Zerbini, Claudia Cappra, Carlos Lopes, e aos dois profissionais que não puderam se identificar. Agradecimento especial ao Pedro Dameto, parceiro em apoiar muitas de minhas pesquisas, mostrando que nem sempre há GAP entre o discurso e prática das pessoas. E à querida Cristina Baldini, que a me ajudou a fazer as transcrições das entrevistas.

Ao CNPq pela bolsa concedida durante o período do mestrado.

A todas as pessoas que direta ou indiretamente contribuíram para a realização e conclusão de mais esta importante etapa de minha vida.

E não podia finalizar sem agradecer a Deus, e a toda energia boa que envolve esse mundo! 
"O problema não é o problema, o problema é a atitude com relação ao problema".

Frase atribuída a Kelly Young 



\section{RESUMO}

DALMARCO, D.A.S. Barreiras à adoção das certificações sustentáveis por parte de empresas de bens de consumo: uma proposta de sistematização. 2017. $216 \mathrm{f}$. Dissertação (Mestrado) - Faculdade de Economia, Administração e Contabilidade, Universidade de São Paulo, São Paulo, 2017.

As certificações sustentáveis são consideradas um caminho possível para alavancar o um consumo mais sustentável por parte dos consumidores, por meio da comunicação, nas embalagens dos produtos, de atributos socioambientais que eles carregam, verificados por uma terceira parte. Considerando as relações entre empresas, as certificações também podem apoiar organizações que desejam implementar políticas sociais e/ou ambientais, assegurando a rastreabilidade de sua matéria-prima e/ou a qualidade de seu processo produtivo. Porém, nota-se que ainda há diversas barreiras para uma maior adoção destas certificações, seja por parte dos consumidores, que não os reconhecem, não compreendem suas mensagens, ou não os valorizam no momento da compra; seja por parte das empresas, que ainda não conseguiram identificar os reais benefícios de sua adoção, seja por falta de demanda de mercado, ou pela falta de comprovação da efetiva redução de seus impactos socioambientais. Neste contexto, o presente estudo teve como objetivo fazer uma sistematização das barreiras que dificultam a utilização das certificações sustentáveis por parte de empresas de bens de consumo. Foram levantadas diversas barreiras às certificações, sem ser possível encontrar uma iniciativa de consolidação e sistematização das mesmas. Para avançar o conhecimento relacionado ao tema, procedeu-se a análise de dois casos de certificações relevantes no Brasil, o Forest Stewardship Council (FSC) e o "I'm Green". Os principais resultados alcançados foram: i) a atualização da listagem de barreiras previamente levantada; ii) a primeira proposta de classificação das barreiras às certificações sustentáveis; e iii) o primeiro mapeamento da atuação das barreiras de acordo com o stakeholder envolvido no processo. Nota-se que os obstáculos enfrentados pelas empresas de bens de consumo são principalmente referentes à sua relação com seus fornecedores de insumo e os padronizadores, além de diversas questões internas à organização. Observa-se, também, que as barreiras comuns às duas certificações estudadas estão concentradas na fase inicial de adoção das mesmas, e são oriundas, em sua maioria dos stakeholders externos. Já as barreiras específicas de cada certificação tem algumas particularidades: no caso do FSC elas estão concentradas na fase de implementação, e envolve uma gama maior de stakeholders; e no caso "I'm Green" há uma dispersão entre a fase anterior de implementação, e a fase de implementação, propriamente, sendo que elas são focadas no fornecedor. O presente estudo abriu espaço para uma maior compreensão sobre como a questão da rotulagem sustentável vem sendo considerada no ambiente corporativo, podendo ser endereçado de diversas formas pela academia, pelas empresas, pelos padronizadores e pelos demais envolvidos com o tema.

Palavras-chave: Administração de materiais, Administração de marketing, Certificações sustentáveis, Barreiras, Sistematização, Stakeholders. 


\begin{abstract}
DALMARCO, D.A.S. Barriers to the adoption of sustainable standards by consumer goods companies: a systematization proposal. 2017. 216 f. Dissertação (Mestrado) - Faculdade de Economia, Administração e Contabilidade, Universidade de São Paulo, São Paulo, 2017.

Sustainable standards are considered a possible way to leverage a more sustainable consumption by consumers, through the communication, on the packaging of products, of socio-environmental attributes that they carry, verified by a third party. Considering business-to-business relationships, they can also support companies that want to implement social and/or environmental policies, assuring the traceability of their raw material or the quality of their production process. However, it is noted that there are still several barriers to greater adoption of these standards, either by consumers, who do not recognize them, do not understand their messages, or do not value them at the time of purchase; Or by companies that have not yet been able to identify the real benefits of their adoption, either due to a lack of market demand or to the lack of measurement of the effective reduction of their socio-environmental impacts. In this context, the present study aimed to systematize the barriers that hinder the use of sustainable standards by companies of consumer goods. Several barriers to the adoption of the standards by companies were raised, but no study until now had the initiative to consolidate them. In order to advance the knowledge related to the theme, two cases of relevant standards in Brazil, the Forest Stewardship Council (FSC) and the "I'm Green" were analyzed. The main results achieved were: i) the list of barriers previously raised updated; ii) the first classification proposal of the barriers to sustainable standards; and iii) the first map of barriers to sustainable standards according to the stakeholder involved. It is noted that the obstacles faced by consumer goods companies are mainly related to their relationship with their suppliers and standardization body, as well as various issues internal to the organization. It is also observed that the common barriers to the two certifications are concentrated in the initial phase of their adoption, and come mainly from external stakeholders. The specific barriers of each certification have some peculiarities: in the case of FSC they are concentrated in the implementation phase, and involve a wider range of stakeholders; in the case of "I'm Green" there is a dispersion between the previous phase of implementation and the implementation phase, properly, being that they are focused on the supplier. The present study opens space for a better understanding of how the issue of sustainable labeling is being considered in the corporate environment, and can be addressed in different ways by the academy, companies, standardizers and others involved with the theme.
\end{abstract}

Key-words: Supply chain management, Marketing management, Sustainable Labels, Barriers, Systematization, Stakeholders. 


\section{SUMÁRIO}

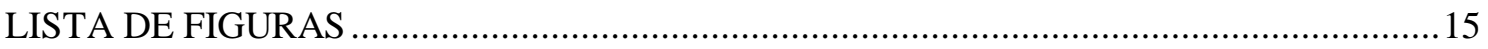

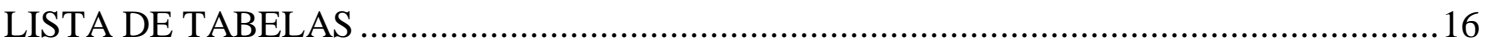

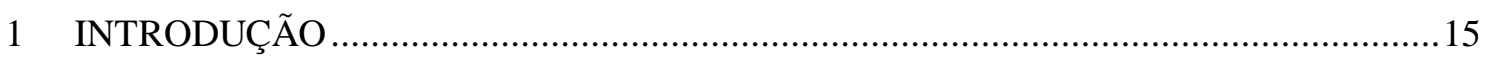

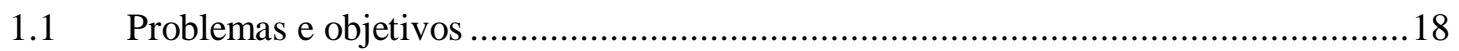

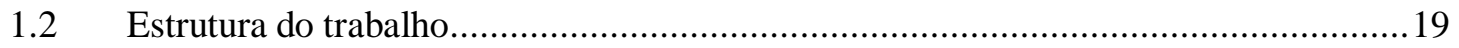

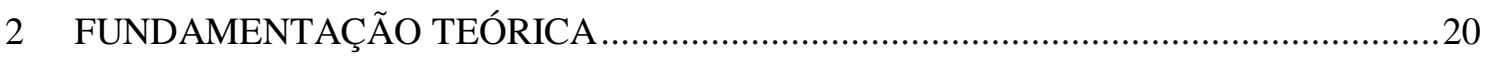

2.1 Informações sobre sustentabilidade de produtos (ISP): as certificações sustentáveis .20

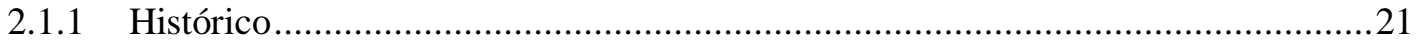

2.1.2 Critérios para calcular os impactos ambientais dos produtos ................................23

2.1.3 Formas de comunicar as ISP aos consumidores ..................................................26

2.1.4 As diferentes formas de classificar as ISP.............................................................. 31

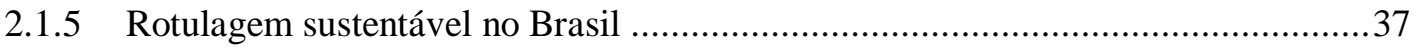

2.2 Os stakeholders envolvidos com as certificações sustentáveis ..................................48

2.2.1 Estudos sobre certificações nas relações B2C e B2B ………………....................56

2.2.2 Gestão da cadeia de suprimentos sustentável (GCSS) …....................................59

2.3 As barreiras enfrentadas pelas empresas na adoção de certificações sustentáveis ......64

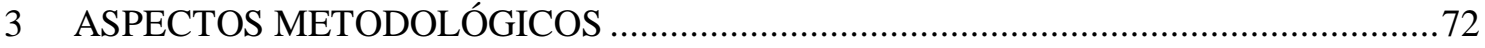

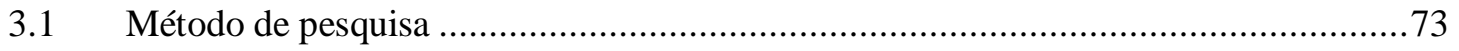

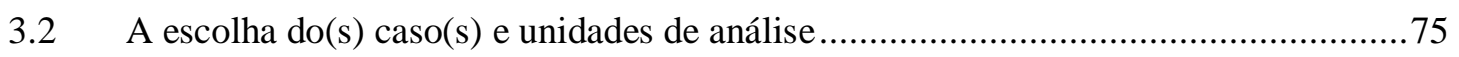

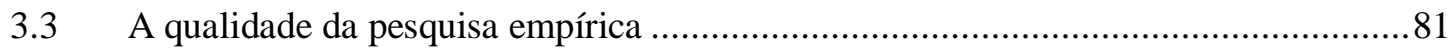

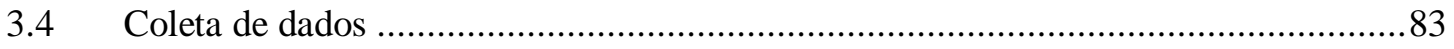

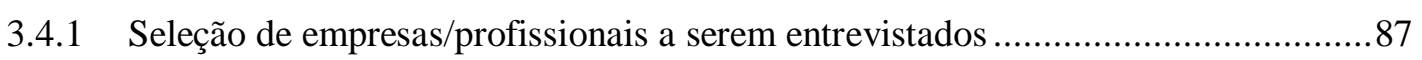

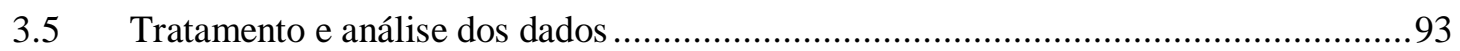

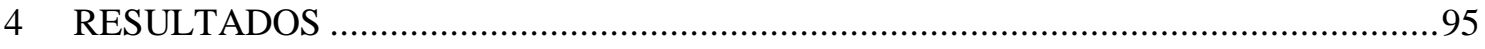

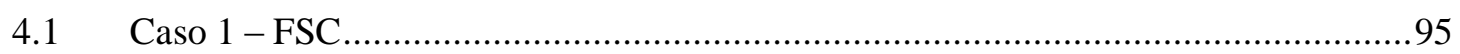

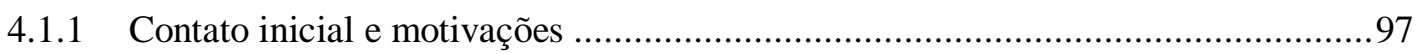

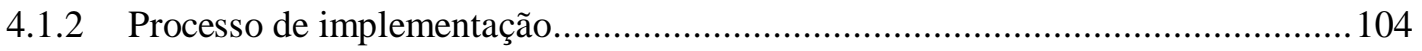

4.1.3 Impactos que a certificação trouxe ao negócio ..................................................... 109

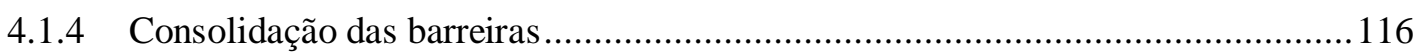

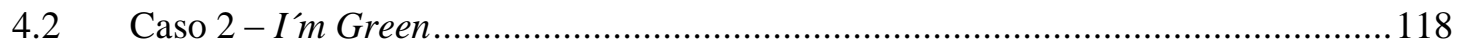

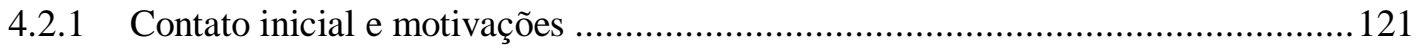

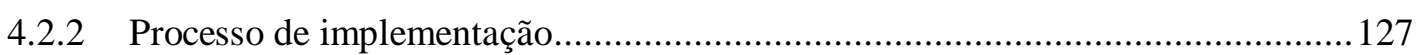

4.2.3 Impactos que a certificação oferece ao negócio ...................................................135

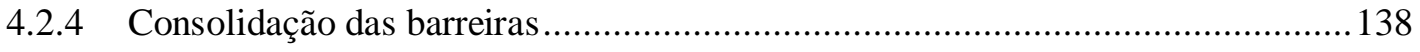

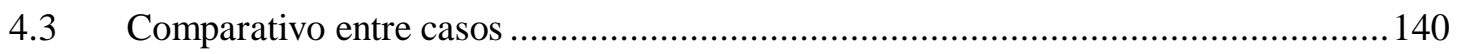

4.4 Classificação das barreiras encontradas nos casos ................................................... 143

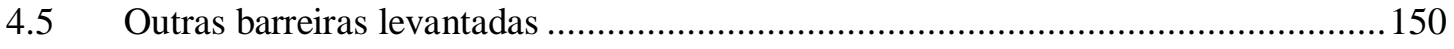

4.6 Consolidação final das barreiras e proposta de modelo conceitual ............................155 


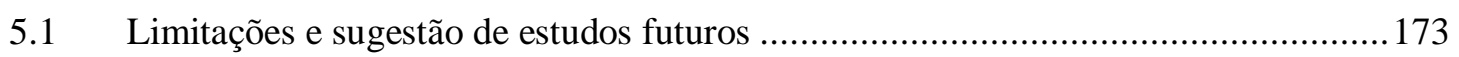

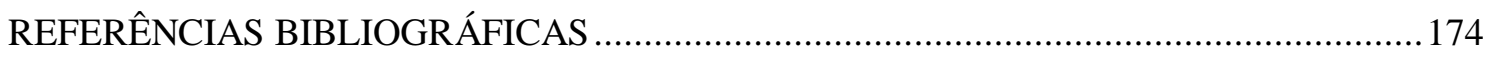

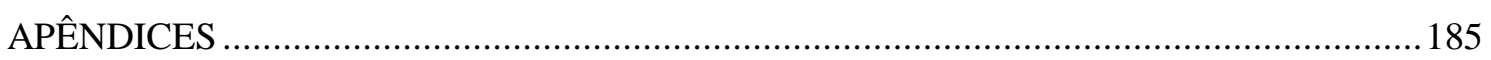

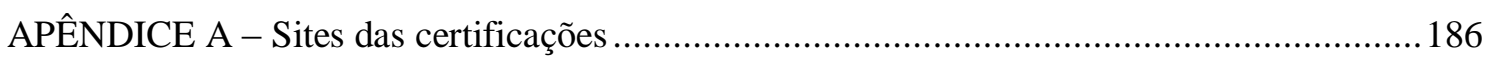

APÊNDICE B - E-mail convite para participação na pesquisa ............................................... 188

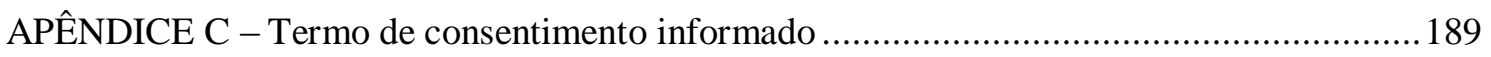

APÊNDICE D - Roteiro de entrevista: empresa B2C que não adota as certificações............... 190

APÊNDICE E - Roteiro de entrevista: empresa B2C que adota certificações ........................... 195

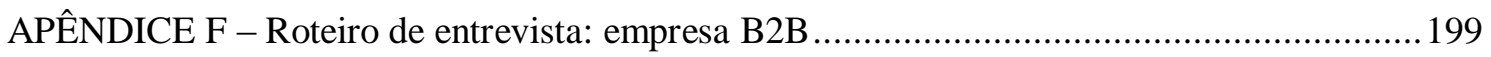

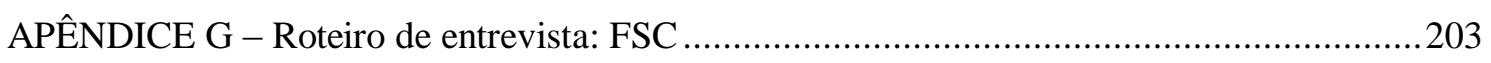

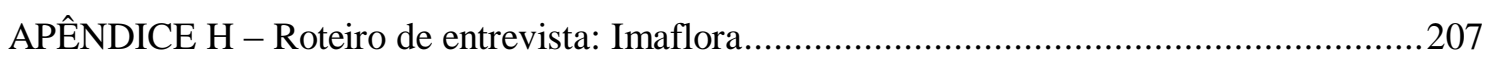

APÊNDICE I - Roteiro de entrevista: Braskem............................................................... 211 


\section{LISTA DE FIGURAS}

Figura 1 - Classificação da rotulagem ambiental nos Estados Unidos ........................................32

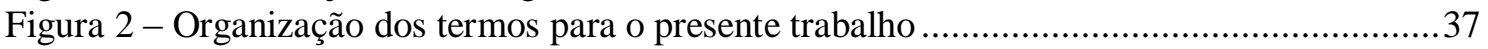

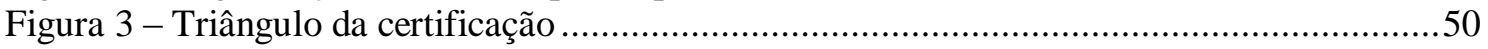

Figura 4 - Como as certificações são usadas pelos diversos stakeholders envolvidos .................51

Figura 5 - Interação entre stakeholders envolvidos no processo de certificação ........................52

Figura 6 - Mapeamento simplificado de stakeholders e seus principais papéis...........................54

Figura 7 - Divisão de stakeholders em grupos de acordo com seu papel no contexto da

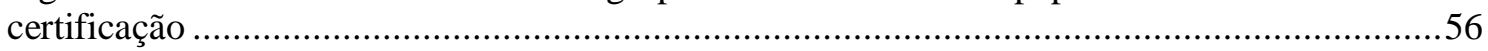

Figura 8 - Principais stakeholders envolvidos na adoção da certificação por parte das empresas

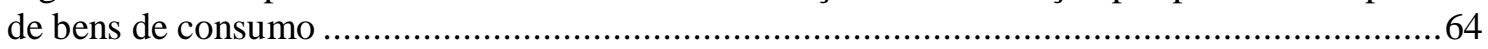

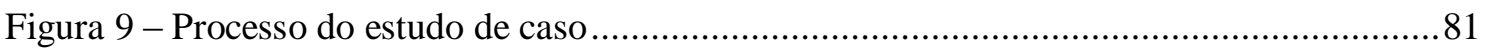

Figura 10 - Comunicação do lançamento de produto com o PE verde da Natura......................130

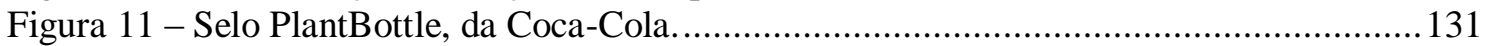

Figura 12 - Selo "materiais de origem renovável", da empresa DuPont .................................133

Figura 13 - Mapeamento de atuação das barreiras de acordo com cada stakeholder................165

Figura 14 - Os estudos sobre certificações em diferentes contextos ......................................172 


\section{LISTA DE TABELAS}

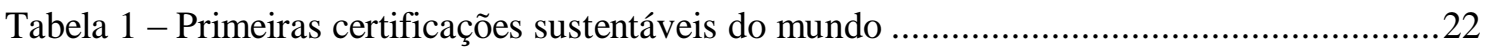

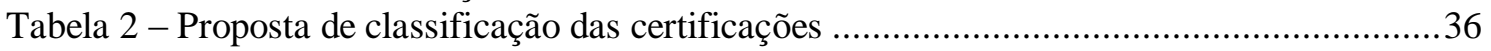

Tabela 3 - Certificações sustentáveis internacionais presentes no Brasil (não exaustivo) ..........40

Tabela 4 - Certificações sustentáveis com origem brasileira (não exaustivo) ............................43

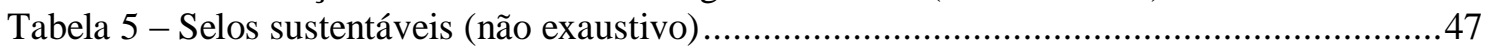

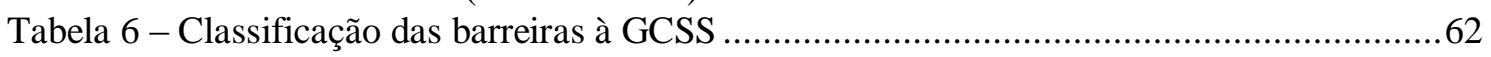

Tabela 7 - Barreiras às certificações sustentáveis enfrentadas pelas empresas..........................68

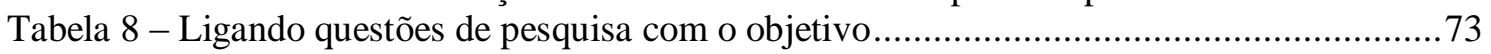

Tabela 9 - Situações relevantes para diferentes estratégias de pesquisa ......................................74

Tabela 10 - Tipos básicos de projetos para os estudos de caso ..............................................77

Tabela 11 - Vantagens e desvantagens de cada tipo de certificação para o estudo .....................78

Tabela 12 - Relação de cada tipo de stakeholder com as certificações escolhidas .....................80

Tabela 13 - Táticas do estudo de caso para quatro testes de projeto ........................................... 82

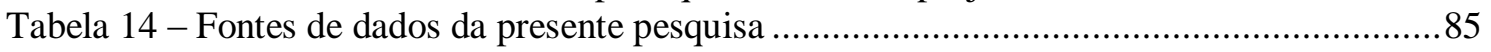

Tabela 15 - Caracterização das empresas participantes do estudo .........................................90

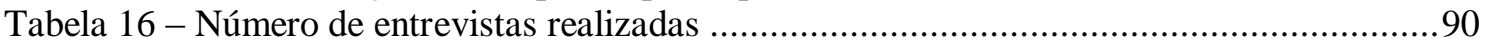

Tabela 17 - Caracterização dos entrevistados ...................................................................... 91

Tabela 18 - Consolidado de empresas - caso FSC e "I'm Green" .........................................92

Tabela 19 - Consolidado de empresas - caso I'm Green..................................................... 92

Tabela 20 - Consolidação: formas de contato, motivações e barreiras levantadas (FSC) .........103

Tabela 21 - Consolidação: atores envolvidos, tempo/custo e barreiras levantadas (FSC).........109

Tabela 22 - Produtos Natura com selo FSC ....................................................................... 112

Tabela 23 - Consolidação: impactos causados e barreiras levantadas (FSC) ...........................114

Tabela 24 - Barreiras encontradas em cada etapa da implementação (FSC) ...........................116

Tabela 25 - Barreiras específicas de empresas que devem obter certificação FSC ................... 117

Tabela 26 - Consolidação: formas de contato, motivações e barreiras levantadas (I'm Green) 125

Tabela 27 - Ícones desenvolvidos pela Natura para fazer referência ao PE Verde ................... 130

Tabela 28 - Consolidação: atores envolvidos, tempo, custo e barreiras levantadas (I'm Green)

Tabela 29 - Consolidação: impactos causados e barreiras levantadas (I'm Green)

Tabela 30 - Barreiras encontradas em cada etapa da implementação (I'm Green) ........................ 139

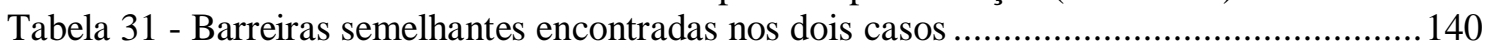

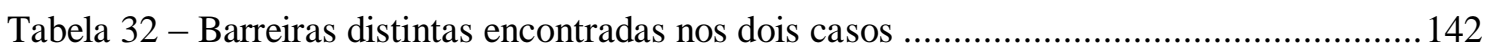

Tabela 33 - Classificação das barreiras comuns encontradas em cada etapa............................ 144

Tabela 34 - Classificação das barreiras específicas do FSC encontradas em cada etapa ..........145

Tabela 35 - Classificação das barreiras específicas do I'm Green encontradas em cada etapa 146

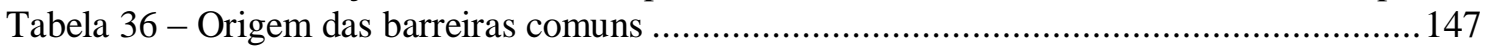

Tabela 37 - Origem das barreiras distintas ................................................................... 148

Tabela 38 - Consolidação: principais atores envolvidos na implementação das certificações . 149

Tabela 39 - Consolidação e classificação das outras barreiras levantadas na pesquisa ..............154

Tabela 40 - Classificação das barreiras levantadas na revisão bibliográfica .............................155

Tabela 41 - Consolidação das barreiras às certificações sustentáveis ......................................160

Tabela 42 - Proposta de classificação das barreiras às certificações sustentáveis...................... 166

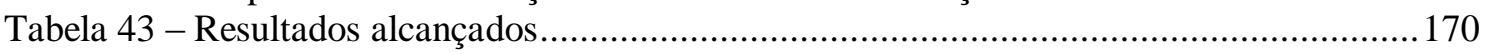




\section{INTRODUÇÃO}

Diversos autores destacam a década de 1960 como um marco no debate acerca dos impactos das atividades do ser humano no meio ambiente, e a capacidade do planeta de suportá-las (Berkowitz \& Lutterman, 1968; Gallastegui, 2002; Laroche, Bergeron, \& BarbaroForleo, 2001). Já o começo da década de 1970 marcou o início das pesquisas sobre responsabilidade social como critério de compra dos consumidores (Drumwright, 1994). Nesse momento, diversos autores começaram a fazer pesquisas sobre como a consciência acerca dos limites ambientais impactava o comportamento de consumo das pessoas, e a identificar os diferentes perfis existentes para determinar novas segmentações de mercado (Anderson \& Cunningham, 1972; Antil, 1984; Berkowitz \& Lutterman, 1968; Henion, 1972; Webster, Jr., 1975).

Após 45 anos de muitos estudos, ações e propostas, o desafio de se frear o impacto causado pelas atividades humanas sob os recursos naturais continua existindo. O Painel Intergovernamental sobre Mudança do Clima (IPCC) publicou, em seu último relatório (2014), que o aquecimento do sistema climático é inequívoco e que, desde a década de 1950, muitas das mudanças observadas no clima do planeta não têm precedentes (Intergovernmental Panel on Climate Change [IPCC], 2014). Com isso, mudanças nos estilos de vida atuais precisam ser feitas, a fim de que possamos conter o aquecimento do planeta. Na última Conferência do Clima (COP21 - Paris), em 2015, chegou-se a um acordo para definir o teto aceitável de aquecimento, além da mobilização financeira por parte de países do hemisfério Norte para ajudar os países do Sul a enfrentarem os efeitos da mudança climática (Roger, 2015). Apesar de todas essas discussões e acordos que vem ocorrendo, o aquecimento global continua mostrando sua força, sendo que o mês de fevereiro de 2016 foi o mais quente da história desde que a humanidade iniciou os registros globais de temperatura, em 1880 (Holthaus, 2016).

$\mathrm{Na}$ esfera privada, algumas corporações vêm também fazendo movimentos importantes rumo a novas formas de fazer negócio, mais sustentáveis e inclusivas (Compact \& Accenture CEO Study, 2015). Porém, de acordo com Eric Ryan, co-fundador de uma marca que se declara ambientalmente correta (Seventh Generation), em entrevista para Neff (2010), "fazer escolhas com viés ambiental exige que haja uma mudança de atitude por parte dos consumidores, e as pessoas são muito vagarosas para mudar". O executivo comenta que, de 
diversas maneiras, as empresas estão à frente dos consumidores em relação à oferta de produtos ambientalmente melhores. $\mathrm{O}$ mesmo foi destacado por uma pesquisa da Accenture com CEOs de grandes empresas de todo o mundo, em 2010, que mostrou que muitas delas ainda esperavam uma mudança na demanda de mercado para que pudessem fazer mudanças em suas estratégias de negócio, rumo a práticas mais sustentáveis (Lacy, 2013). Em 2013, outra pesquisa da Accenture continuava fazendo o mesmo diagnóstico: os sinais dos consumidores ainda são misturados, e o interesse dos investidores acontece de maneira isolada, pequena. Com isso, algumas empresas líderes conseguiram mudar seus negócios, mas a maioria continuava num meio do caminho, ainda incapazes de saber como e quando fazer esse movimento rumo à inclusão da sustentabilidade em suas estratégias (UN Global Compact \& Accenture, 2013).

O consumidor, desde a década de 1970, parece estar disposto a mudar seu comportamento, rumo a um consumo mais sustentável, que considere questões sociais/ambientais em suas escolhas de compra (Anderson \& Cunningham, 1972; Berkowitz \& Lutterman, 1968), além de hábitos pós-compra (Webster, Jr., 1975). Mas diversos estudos já mostraram que há uma lacuna entre o discurso ambientalmente/socialmente sustentável versus a prática do dia-a-dia (Barbosa \& Veloso, 2014; Bray, Johns, \& Kilburn, 2011; Cornelissen, Dewitte, Warlop, \& Yzerbyt, 2007; Luchs et al., 2011; Prothero et al., 2011; Roberts, 1996; Roberts \& Bacon, 1997; Zabkar \& Hosta, 2013), e que há diversos fatores impeditivos da mudança de atitude (Bonini \& Oppenheim, 2010; Bray et al., 2011; Stern, 1999). Com relação à informação, existe o problema do pouco conhecimento dos consumidores em relação a questões ambientais, e, sob outro ponto de vista, o excesso de comunicações empresarias com apelos sustentáveis, o que pode confundir os consumidores no momento da compra (Bray et al., 2011; Hamza \& Dalmarco, 2012; Leire \& Thidell, 2005).

Neste contexto, os selos e/ou certificações sustentáveis são considerados peças chave para apoiar escolhas mais sustentáveis por parte dos consumidores (Gallastegui, 2002; Organização das Nações Unidas [ONU], 1992; Thøgersen, 2000; WRI \& Ecolabel Index, 2010), ainda mais pensando que $76 \%$ das decisões de compra de produtos acontecem no ponto de venda (Point-of-Purchase Advertising International - POPAI, 2014). Nota-se que desde a Conferência das Nações Unidas sobre o Meio Ambiente e o Desenvolvimento (Rio92), quando os selos foram considerados uma importante ferramentas para apoiar os consumidores a fazer escolhas mais conscientes (ONU, 1992), houve uma grande evolução no 
que tange ao número de selos disponíveis em todo o mundo - de uma média de lançamentos de 1,2 selos ao ano, de 1979 a 1992, para uma média de 5,7 selos ao ano, de 1993 a 2010 (WRI \& Ecolabel Index, 2010), mas percebe-se, também, que os consumidores ainda ficam confusos em relação à quantidade de informações e conteúdo das mesmas contidas nas embalagens dos produtos (Consumers International, 1999; De Pelsmacker \& Janssens, 2007; Hamza \& Dalmarco, 2012).

Para compreender melhor como funcionam os esquemas de certificação, alguns autores elaboraram mapeamentos de stakeholders envolvidos no processo (Ham, 2007; SustainAbility, 2011; Van Amstel, Driessen, \& Glasbergen, 2008). O mais recente encontrado foi o proposto pela UNEP (2015a), que mapeou sete grupos de interesse (consumidores, ONGs/imprensa, organizações certificadoras, empresas, fornecedores industriais, pesquisadores/consultores e organizações governamentais), e relatou qual seria o papel de cada um. Diversos estudos tiveram como foco avaliar a perspectiva de algum destes grupos acerca de questões relacionadas à certificação, de forma geral, ou com foco em alguma certificação específica. Em relação aos consumidores, por exemplo, muitos autores já buscaram compreender opiniões e atitudes em relação aos selos e/ou certificações - seja se compreendem o que significa (Borin, Cerf, \& Krishnan, 2011; Hartikainen, Roininen, Katajajuuri, \& Pulkkinen, 2014), seja se o utilizam como fator de decisão de compra (Grunert, Hieke, \& Wills, 2014) ou para compreender como seria o processo de utilização do mesmo (Thøgersen, Haugaard, \& Olesen, 2010).

Já sob a perspectiva da produção, o uso das certificações como um instrumento de negócios é outro campo de estudo em desenvolvimento, principalmente relacionado à gestão da cadeia de suprimentos sustentável (GCSS), no qual são utilizadas com o objetivo de compor políticas relacionadas à sustentabilidade das empresas. Neste campo, porém, a produção acadêmica ainda é incipiente, sendo que as considerações sobre o tema estão geralmente relacionadas à ISO 14001 (gestão ambiental) e/ou OHSAS 18001 (saúde e segurança ocupacional) e/ou SA8000 (responsabilidade social) (Chan, He, \& Wang, 2012; Sarkis, 2003; Seuring \& Müller, 2008; Silva, Shibao, \& Santos, 2016; Srivastava, 2007; Zhu, Sarkis, \& Geng, 2005). Menções a outras certificações voluntárias de mercado (como FSC, Fairtrade ou Rainforest Alliance) ainda são raras nos estudos sobre GCSS, o que pode ser considerado uma lacuna de pesquisa, dado que as certificações podem ser consideradas mais relevantes para a relação entre empresas (B2B) do que para a relação entre a empresa de bens 
de consumo e seu consumidor final (B2C), devido a questões de posicionamento da empresa no mercado ou reconhecimento de responsabilidade por parte dos investidores do setor financeiro (Iseal Alliance, 2016) - ou seja, considerando que as empresas fazem uso deste instrumento como forma de garantir práticas de responsabilidade socioambiental em sua operação.

Diversas são as barreiras enfrentadas pelas empresas para a adoção das certificações sustentáveis, como aumento de custos (Ham, 2007; Piotrowski \& Kratz, 2005; Rubik, Scheer, \& Iraldo, 2008; SustainAbility, 2011), imprevisibilidade da demanda (D’Souza, 2004; Gallastegui, 2002; Iseal Alliance, 2010; Lacy, 2013; Pedersen \& Neergaard, 2006; SustainAbility, 2011) ou o nível de rigidez dos critérios estabelecidos pelas padronizadoras (Gallastegui, 2002; Ham, 2007; Piotrowski \& Kratz, 2005; SustainAbility, 2011), porém não foi possível encontrar estudos que tivessem como foco o mapeamento e análise destas barreiras, e como elas atuavam no relacionamento entre os stakeholders envolvidos no processo.

\subsection{Problemas e objetivos}

Dado o contexto apresentado, a presente pesquisa abordará a seguinte questão: “como as barreiras às certificações sustentáveis atuam no contexto empresarial, impedindo o aumento da adesão às certificações por parte das empresas de bens de consumo"? O objetivo principal será fazer uma sistematização das barreiras que dificultam a utilização das certificações sustentáveis por parte de empresas de bens de consumo. Como objetivos específicos, pode-se listar:

i) Mapear o processo de decisão pela utilização das certificações nas empresas, para que seja possível avaliar como as barreiras atuam;

ii) Levantar outras questões relacionadas à adoção das certificações, como motivações, prazos envolvidos, investimento necessários e impactos causados;

iii) Levantar quais são as áreas das empresas mais relacionadas à questão da certificação sustentável, a fim de compreender papéis e responsabilidades de cada uma no processo de certificação; e 
iv) Avaliar se há semelhanças em relação às barreiras encontradas para diferentes certificações.

\subsection{Estrutura do trabalho}

Esta dissertação está estruturada da seguinte forma: o referencial teórico primeiro abordará o tema das informações sobre sustentabilidade dos produtos (ISP) - o histórico sobre o tema, critérios usados para mensurar os impactos ambientais dos produtos, as formas de classificar estas informações e comunica-las aos consumidores, além da apresentação de um levantamento sobre a rotulagem sustentável no Brasil. Em seguida, serão apresentados mapeamentos dos principais stakeholders envolvidos no processo de rotulagem sustentável, com a proposição de um novo mapeamento desenvolvido pela autora. Considerando a definição de certificação sustentável proposta pela Agência de Proteção Ambiental (EPA) dos Estados Unidos, que propõe dois principais objetivos - por um lado, de influenciar as relações comerciais entre empresas (B2B), e por outro, as escolhas de consumidores finais (B2C), abre-se espaço pra apresentar as linhas de pesquisa relacionadas aos dois temas, com o posterior detalhamento das relações B2B, foco do presente trabalho, por meio da apresentação de estudos relacionados a cadeia de suprimentos sustentáveis. O referencial teórico é finalizado com o levantamento das barreiras encontradas para adoção das certificações sustentáveis por parte das empresas. Na sequência será detalhado o método de pesquisa escolhido e realizada a análise/discussão dos dados coletados, consolidando-se as contribuições do presente trabalho. O encerramento da dissertação conta com as considerações finais e limitações do estudo, além de levantamento de possíveis pesquisas futuras a serem realizadas sobre o tema. 


\section{FUNDAMENTAÇÃO TEÓRICA}

\subsection{Informações sobre sustentabilidade de produtos (ISP): as certificações sustentáveis}

Desde a década de 1940 é possível encontrar estudos acerca da discussão sobre as informações contidas nas embalagens de produtos a fim de informar os consumidores e, com isso, possibilitar que fizessem escolhas mais conscientes. Voltolini (2010) comenta que os primeiros rótulos obrigatórios em produtos surgiram na Europa, nessa época, com a função de advertência, destacando a presença de substâncias químicas potencialmente danosas à saúde do consumidor. Nos Estados Unidos, no mesmo período, houve grande debate acerca da rotulagem de produtos alimentícios, dado que havia uma proposta do Governo de se estabelecer um critério de notas a determinados alimentos, de acordo com algumas variáveis relacionadas ao seu processo produtivo e sua qualidade final. As principais discussões estavam relacionadas basicamente a quatro grandes temas: i) o quanto deveria (ou não) ser regulada pelo governo; ii) como os consumidores compreendiam e usavam as informações no momento da compra; iii) avaliar se seria possível fazer uma padronização das formas de acessar e classificar os processos produtivos de produtos tão diferentes; e iv) o quanto ficaria mais caro realizar esses estudos e classificações de padronização por parte dos fornecedores, e o quanto o consumidores estariam dispostos a pagar pelos eventuais custos mais altos dos produtos (Bader \& Hotchkiss, 1940; Coles \& Erdman, 1945; Kebker, 1943; Mossman, 1943).

Já na década de 70, num dos primeiros estudos acerca de selos de aprovação de produtos, Parkinson (1975) demonstrou que os produtos com algum tipo de selo eram avaliados de forma mais favorável do que os que não tinham nenhuma comunicação desse tipo, argumentando que os selos e/ou certificações influenciavam de forma significante o comportamento de compra dos consumidores. O autor identificou e testou diferentes fontes dos selos, seja de publicações de consumidores, grupos independentes, associações profissionais, empresas ou agências governamentais, e concluiu que, de forma geral, os consumidores não compreendiam o que eles significavam, sugerindo que esse tipo de comunicação deveria ser regulamentado pela Comissão Federal de Comércio (Federal Trade Comission - FTC). Vale ressaltar que não eram comunicações referentes a questões sociais e/ou ambientais, mas sim a endossos de instituições aplicados nas embalagens sobre a qualidade/aprovação dos produtos. 
Apesar de todos os esforços, estudos e políticas públicas desenvolvidas desde o início das discussões sobre comunicação realizada nas embalagens dos produtos, os desafios acima relacionados continuam sendo bastante atuais, porém com um escopo maior: de atributos específicos dos produtos alimentícios e de selos de qualidade/aprovação feito por instituições, para características econômicas, sociais, ambientais e éticas de todas as categorias de produtos, de parte ou de todo o seu processo produtivo, com ou sem validação feita por terceiros.

A seguir será apresentado um breve histórico em relação às certificações sustentáveis e os critérios desenvolvidos para mensurar o impacto dos produtos no meio ambiente. Em seguida serão descritas algumas formas de comunicar as informações sobre sustentabilidade dos produtos (ISP) aos consumidores, e apresentadas algumas propostas de classificações para as ISP, mostrando a diferença entre os termos utilizados neste contexto e estabelecendo a definição que será usada no presente trabalho. Por fim, mostra-se um levantamento sobre a rotulagem sustentável no Brasil.

\subsubsection{Histórico}

A primeira certificação sustentável de que se tem notícia é o Blue Angel, que foi lançado por uma companhia governamental alemã em 1978. Diversas certificações sustentáveis surgiram nas décadas seguintes, como: Environmental Choice (Canadá, 1988); Green Seal, (Estados Unidos, 1989); Ecomark (Japão, 1989); White Swan (Conselho Nórdico, 1989); Ecolabel (União Europeia, 1992). Todas estas certificações existem até hoje, e abrangem produtos e serviços, exceto o Ecomark, que é direcionado apenas para produtos (vide Tabela $1)$. 
Tabela 1 - Primeiras certificações sustentáveis do mundo

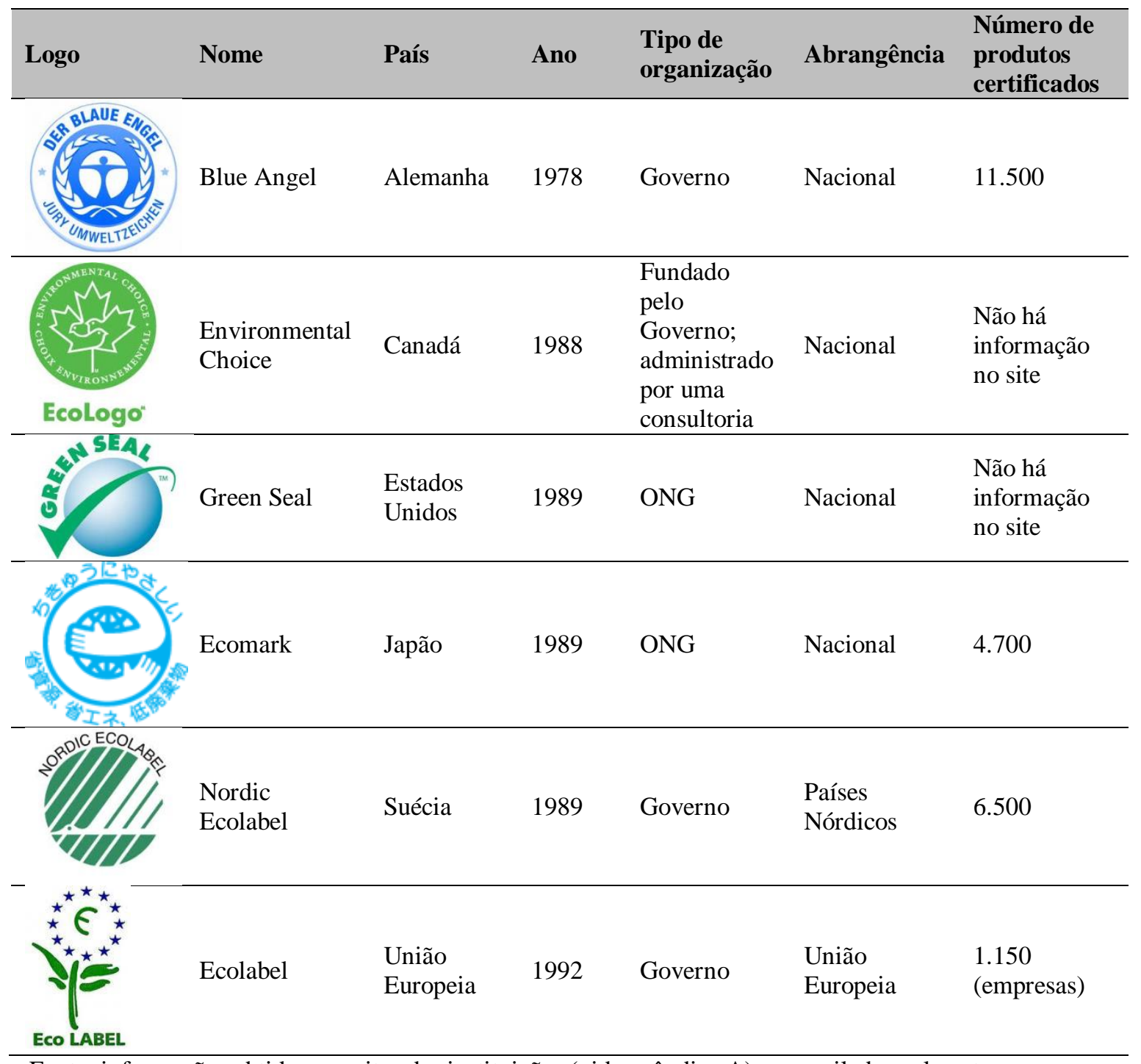

Fonte: informações obtidas nos sites das instituições (vide apêndice A) e compiladas pela autora.

As conquistas desses selos são celebradas em suas páginas na internet, como o Blue Angel, que verificou em pesquisa que $76 \%$ dos consumidores alemães tem conhecimento da marca, e 39\% deles o consideram em sua decisão de compra (The Blue Angel, 2016). Já o Nordic Ecolabel é conhecido por 94\% dos cidadãos dos países nórdicos (Nordic Ecolabelling, 2016). Além disso, todos os selos possuem a lista de produtos certificados disponível para busca em suas páginas na internet.

Aplicar o conceito de produção e consumo sustentáveis demanda que se defina o que são produtos e serviços sustentáveis, como eles são produzidos e consumidos, e por quais meios eles podem ser identificados e selecionados pelos consumidores. Em 1992, a Agenda 21 defendeu que governos e organizações internacionais, em parceria com a iniciativa privada, 
deveriam desenvolver critérios e metodologias para viabilizar a mensuração de impacto ambiental e uso de recursos para produção de bens e serviços em todo o seu ciclo de vida, sendo que os resultados dessa mensuração tinham que ser transformados em indicadores claros a fim de informar consumidores e tomadores de decisão. O objetivo era promover as condições necessárias para fazer emergir um consumo mais consciente por parte dos consumidores, por meio da disponibilização de informações sobre as consequências de seus hábitos de consumo e escolhas, fazendo com que os mesmos escolhessem e valorizassem cada vez mais os produtos mais sustentáveis (ONU, 1992).

Nota-se que desde então houve um grande evolução no que tange ao número de selos disponíveis em todo o mundo - de uma média de lançamentos de 1,2 selos ao ano, de 1979 a 1992, para uma média de 5,7 selos ao ano, de 1993 a 2010 (WRI \& Ecolabel Index, 2010), sendo que hoje o Ecolabel Index (um diretório internacional de certificações sustentáveis) conta com 463 certificações cadastradas, oriundas de 199 países, abrangendo 25 setores da indústria (Ecolabel Index, 2016).

\subsubsection{Critérios para mensurar os impactos ambientais dos produtos}

Como já foi apresentado, as décadas de 1960 e 1970 foram marcos em relação ao aumento da preocupação com o meio ambiente e com o quanto as atividades que os seres humanos desempenham aceleram a degradação do mesmo. Para Maimon (1994), foi nesse período que também surgiram diversos mecanismos para gestão ambiental por parte das empresas, com o objetivo de atender as pressões externas referentes ao impacto de suas atividades: auditorias, avaliações de impacto e de risco, análise do ciclo de vida dos produtos, indicadores, sistemas de gestão, certificações e rótulos, entre outros.

Muitos outros instrumentos de gestão ambiental surgiram desde então, e com eles diversas maneiras de avaliar os impactos de produtos. A principal delas a análise de ciclo de vida do produto (ACV) que, de acordo com Tsoulfas e Pappis (2006), é um método pelo qual a energia, os materiais consumidos e os diferentes tipos de emissões relacionados a um produto específico são mensurados, analisados e atribuídos ao ciclo de vida completo desde um ponto de vista ambiental. Essa analise também pode ser compreendida conforme a expressão "do berço ao túmulo" - sendo o berço o meio ambiente como fonte de recursos 
naturais, e túmulo, o meio ambiente como receptáculo dos resíduos dos processos de produção e consumo. Para isso, Barbieri e Cajazeira (2009) ressaltam que é necessário desenvolver instrumentos que possam identificar e quantificar os impactos ambientais ao longo da cadeia, o que vale dizer, as etapas envolvidas no processo de produção, distribuição e uso, bem como as etapas dos fluxos reversos associados à recuperação de materiais processados ou usados para utilizá-los novamente. Vale ressaltar que o conceito do ACV é o que dá base para muitos dos instrumentos existentes - ou seja, a empresa pode buscar controlar a emissão de carbono, ou a utilização da água, ou a geração de lixo - mas o ideal é sempre considerar o ciclo de vida do produto/serviço, ou processo, como um todo.

Outra forma de se realizar a mensuração de impacto ambiental de um produto é a pegada ecológica, desenvolvida pela Global Footprint Network (GFP) - uma organização internacional, sem fins lucrativos, que trabalha pelo desenvolvimento sustentável (Global Footprint Network, 2016). Segundo a organização, este método permite medir a oferta e a demanda dos recursos naturais do planeta: pelo lado da oferta, a biocapacidade representa as áreas de terra biologicamente produtivas do planeta, incluindo florestas, pastagens, terras agrícolas e de pesca. Estas áreas, se deixadas intactas, também podem absorver grande parte dos resíduos gerados pela atividade humana, especialmente as emissões de carbono. A biocapacidade deve, então, ser comparada com a demanda humana na natureza, a pegada ecológica, que representa a área produtiva necessária para fornecer os recursos renováveis que estão sendo utilizados e para absorver seus resíduos. Ainda de acordo com a GFP, o conceito da pegada ecológica, estabelecido em 1990, posteriormente deu início a um movimento maior de cálculo dos impactos causados pelos seres humanos, seja considerando somente os indivíduos, ou cidades, produtos, empresas, países. Como exemplo, pode-se citar a pegada hídrica de um produto, que é o volume de água utilizado para produzi-lo, medido ao longo de toda cadeia produtiva. É um indicador multidimensional, que mostra os volumes de consumo de água por fonte e os volumes de poluição pelo tipo de rejeito produzido (Hoekstra, Chapagain, Aladaya, \& Mekonnen, 2011). Já a pegada de carbono atualmente é, de acordo com Centro de estudos em sustentabilidade [GVces] (2016), a ferramenta mais utilizada mundialmente por empresas e governos para compreender, quantificar e gerenciar suas emissões de gases do efeito estufa (GEEs). No caso dos produtos, segundo o Greenhouse Gas Protocol (2016), as empresas podem medir os GEEs associados a todo o seu ciclo de vida, incluindo as matérias-primas, produção, transporte, estocagem, uso e descarte. Para a 
instituição, os resultados podem criar vantagem competitiva ao possibilitar um melhor projeto de produto, aumentando a eficiência, reduzindo custos e removendo riscos.

Algumas empresas desenvolveram suas metodologias próprias de medição e comunicação de impacto, como é o caso da tabela ambiental da empresa Natura Cosméticos, lançada em 2007. Maranzato (2006) cita que o objetivo da empresa era ser transparente com os consumidores, acreditando que o conhecimento acerca do que se consome é o primeiro passo para melhorar o mundo. Outra intenção era mostrar os ganhos das iniciativas tecnológicas da Natura em prol do meio-ambiente. Com isso, a empresa desenvolveu uma tabela na qual expõe seis indicadores que mostram a origem das matérias-primas e materiais de embalagem de cada produto. Ainda segundo o autor, a inspiração da iniciativa foi a tabela nutricional de alimentos, informação obrigatória para esse tipo de produto. Os seis indicadores da tabela da Natura são: i) origem vegetal renovável: corresponde a toda parte da formulação que teve sua origem de fonte vegetal. ii) vegetal natural: corresponde a toda parte da formulação que teve sua origem de fonte vegetal e que não sofreu modificações em processos químicos; iii) com certificação de origem: corresponde a toda parte da formulação que teve sua origem certificada por terceiros; iv) material reciclado: corresponde a toda parte da embalagem em que foi utilizado material reciclado pós-consumo, ou seja, componentes que já foram utilizados em algum produto e que foram reprocessados; v) material reciclável: corresponde a toda parte da embalagem que é possível reciclar depois que for utilizada; vi) número recomendado de refilagens: indica o número de vezes que a embalagem original pode ser refilada (Maranzato, 2006).

Outra empresa que desenvolveu seu próprio indicador foi a Timberland, fabricante de roupas, calçados, acessórios e equipamentos esportivos, a qual classifica seus produtos da categoria de calçados numa escala de zero a dez, usando um sistema criado para comparar o impacto ambiental dos mesmos - quanto menor a nota, menor a pegada ambiental associada para produzi-lo, considerando três principais indicadores: emissão de gases do efeito estufa (impacto no clima), utilização de produtos químicos e consumo de recursos. Uma segunda forma de comunicar o impacto dos produtos é a chamada "tabela nutricional de calçados", a qual apresenta indicadores relacionados a energia renovável, utilização de PVC e materiais orgânicos, recicláveis ou renováveis, além do número de árvores plantadas pela empresa num determinado período (Timberland, 2016). 
A crescente complexidade e inter-relação entre as diferentes métricas e iniciativas levou à criação de uma ampla variedade de ferramentas que fornecem informações sobre a sustentabilidade dos produtos (ISP) aos consumidores. Segundo a UNEP (2015a), pelo menos 600 ferramentas são estimadas de estar no mercado, o que pode criar confusão e ineficiência. Para a instituição, na falta de um padrão comum de ISP, um esforço deveria ser feito entre as nações para assegurar consenso e operabilidade. O desafio está na possibilidade de se estabelecer comparações entre todas as ferramentas, a fim de facilitar a decisão por parte dos consumidores. As definições e formas de comunicação das ISP serão debatidas nos próximos tópicos.

\subsubsection{Formas de comunicar as ISP aos consumidores}

Com o surgimento de consumidores sustentáveis, as empresas captaram essa nova demanda de mercado e começaram a buscar a diferenciação de seus produtos e/ou serviços em termos ambientais, o que resultou em diversos lançamentos de produtos "ambientalmente amigáveis" entre as décadas de 1980 e 1990 (D’Souza, 2004; Roberts, 1996). Uma questão importante a ser considerada é o quanto a utilização destes apelos sustentáveis por parte das empresas são realmente procedentes, ou se são apenas ferramentas para obter diferenciação sem contar com o compromisso corporativo com questões relacionadas à sustentabilidade.

Num esforço de buscar compreender os tipos de comunicação sustentável utilizados pelas empresas, Kangun, Carlson, e Grove (1991) avaliaram anúncios com apelo ambiental em revistas e jornais e propuseram quatro categorias de apelos, a saber: i) ambíguos - frases ou declarações que são muito amplas e, com isso, não tem um significado claro; ii) omissos que excluem informações importantes que apoiariam na avaliação da veracidade dos mesmos; iii) falsos/mentirosos - apelos que são claramente falsos ou enganosos; iv) aceitáveis - que fazem apelos específicos e justificáveis numa maneira clara e auto explicativa.

Posteriormente, um estudo mostrou que a maioria dos apelos utilizados em embalagens de produtos de uma categoria de bens de consumo fazia uso de termos genéricos e/ou enganosos, como "livre de CFC" ou "contém ingredientes naturais" (Prothero, 1997). Polonsky et al. (1998) também desenvolveram quatro categorias específicas para comunicações realizadas nas embalagens, com base na qualidade de suas explicações: i) aceitáveis - mesma definição 
proposta por (Kangun et al., 1991) (ex.: reciclado - 35\% de plástico pós-consumo foi utilizado na embalagem desse produto); ii) explicação "pobre" - o apelo não é justificado com informação suficiente que o qualifique em relação ao que busca transmitir (ex.: reciclado feito de plástico reciclado); iii) sem explicação - o apelo não inclui informações importantes necessárias para avaliar sua veracidade (ex.: aplicação de termo e/ou imagem de "reciclado" na embalagem, sem descrever a qual parte do produto ele está se referindo); e iv) sem sentido - o apelo contém uma frase ou declaração que é muito fraca, sem um significado claro (ex.: salve o planeta).

Segundo Prothero (1997), a embalagem do produto realmente é uma mídia capaz de passar uma mensagem ambiental de forma efetiva aos consumidores. $\mathrm{O}$ autor comenta que as embalagens já haviam sido alvo de críticas de ambientalistas, mas ressalta que a maioria dos bens de consumo requer algum tipo de proteção, que é fornecida pela mesma, e o uso deste meio para comunicar mensagens ambientais para o consumidor é econômico em termos de investimento de recursos. Porém, um dos grandes desafios das empresas em relação a aplicar sua comunicação sustentável na embalagem é conseguir transmitir o conteúdo desejado por meio de uma ferramenta (um texto ou um ícone, por exemplo) num espaço tão reduzido, competindo com diversas outras informações, como o nome do produto, ingredientes, volumetria, data de validade, textos explicativos (ex.: benefícios, modo de usar), sendo que algumas destas são, inclusive, obrigatórias.

Numa publicação mais recente, Van Amstel, Driessen e Glasbergen (2008) analisaram cinco certificações sustentáveis sobre biodiversidade da Holanda e concluíram que eles falham na comunicação ao consumidor, não conseguindo diminuir a lacuna de informação entre vendedores e compradores. Segundo os autores, os principais problemas encontrados foram: i) sua ambiguidade em relação aos temas ambientais; ii) sua incapacidade de passar informação concreta ao comprador sobre o impacto dos produtos; iii) informação insuficiente sobre a conformidade dos produtores em relação ao processo de certificação; e iv) presença de recomendações, que não podem ser inspecionadas e ou impostas por meio de sanções (os autores defendem que os melhores instrumentos a serem utilizados pelos certificadores são os padrões opcionais e os padrões compulsórios). 
As empresas que fazem uso da rotulagem sustentável sem ter um real comprometimento com a sustentabilidade incorrem no que se determinou chamar de maquiagem verde ${ }^{1}$, que é "o ato de enganar os consumidores sobre as práticas ambientais de uma empresa ou os benefícios ambientais de um produto ou serviço" (UL Environment, 2016). Numa iniciativa realizada pela consultoria de marketing ambiental canadense TerraChoice, foram listados sete tipos do que eles convencionaram chamar de "pecados" da rotulagem ambiental (UL Environment, 2016):

- Pecado do custo ambiental camuflado: declaração de que um produto é "verde" baseado apenas em um atributo ou em um conjunto restrito de atributos ambientalmente corretos, sem atenção a outras importantes questões ambientais, talvez até mais importantes que o próprio atributo destacado;

- Pecado da falta de prova: declaração de que o produto é ambientalmente correto, sem o cuidado de apresentar dados capazes de comprovar essa pretensão;

- Pecado da incerteza: quando uma declaração é tão pobre ou abrangente que seu real significado acaba não sendo devidamente compreendido pelo consumidor;

- Pecado do culto a falsas certificações: quando um produto, por meio de palavras ou imagem, transmite a impressão de que seu atributo socioambiental teve o endosso de um terceiro sem, de fato, contar com ele;

- Pecado da irrelevância: quando se utiliza de um apelo ambiental que, apesar de verdadeiro, não chega a ser importante ou útil para os consumidores que buscam produtos ambientalmente corretas e, pelo fato de ser irrelevante, acaba por distrair o consumidor;

- Pecado do "menos pior": declarações ambientais que podem ser verdadeiras na categoria do produto, mas que costumam distrair a atenção do consumidor do maior impacto ambiental da categoria do produto como um todo (ex.: cigarros orgânicos);

- Pecado da mentira: declarações falsas (Ideia Sustentável, 2010a; UL Environment, 2016).

Uma análise de apelos ambientais presentes em 5.296 produtos de bens de consumo diferentes no Canadá e Estados Unidos concluiu que 95\% deles continham pelo menos um

\footnotetext{
${ }^{1}$ Tradução para o termo em inglês "greenwashing”.
} 
apelo falso, sendo que o problema mais comum foi que os apelos não podiam ser verificados de forma fácil e confiável (TerraChoice, 2010). No Brasil, também há algumas avaliações nesse sentido, sendo que uma levantou 12 casos suspeitos de utilizar ações de marketing que enganam consumidores quanto às práticas ambientais da empresa ou quanto aos seus benefícios ambientais (Proteste, 2016b). A Associação Brasileira de Embalagens (ABRE) declara que:

[...] Declarações incompletas, equivocadas ou mal intencionadas podem levar os consumidores para uma solução menos sustentável, ou até mesmo a deixar de acreditar nas informações fundamentadas, desestimulando o engajamento e mudança de atitude. Por isso, não é correto rotular produtos ou embalagens com mensagens vagas, sem possibilidade de comprovação ou com aspectos irrelevantes frente ao impacto total da cadeia. (Associação Brasileira de Embalagens [ABRE], 2012)

Para evitar esse impacto negativo, diversos estudos ressaltam a importância de se ter maior clareza na comunicação, indicando a necessidade de se criar roteiros e/ou orientações de como desenvolver esses materiais (Leire \& Thidell, 2005; Pickett-Baker \& Ozaki, 2008; Polonsky et al., 1998; Prothero, 1997; Van Amstel et al., 2008). Buscando apoiar e organizar a rotulagem ambiental, a FTC desenvolveu um documento chamado "guia para o uso de apelos ambientais de marketing”, no qual dá orientações específicas de como comunicar diversos tipos de apelos sustentáveis, como: compensações de carbono, selos de aprovação, certificações, produtos que sejam compostáveis, degradáveis, "livres de" alguma substância que pode causar danos ao meio ambiente, "não tóxicos", que não causam danos à camada de ozônio, recicláveis, com componentes reciclados, refiláveis, produzidos com energia renovável, produzidos com materiais renováveis ou que obtiveram alguma fonte de redução de impacto em relação aos seus concorrentes ou ao seu similar que estava anteriormente no mercado. De maneira geral, a instituição clama para que as comunicações sejam baseadas em estudos científicos que possam dar embasamento ao que está sendo informado, além de que sejam feitas de maneira clara, objetiva, concreta, oferecendo dados que qualifiquem a informação, evitando termos muito amplos ou vagos (FTC, 2012). A norma ISO 14020 ("rótulos e declarações ambientais") também contempla orientações nesse sentido, estabelecendo nove princípios gerais a serem considerados:

- Devem ser preciso, verificáveis, relevantes e não enganosos; 
- Procedimentos e requisitos não devem ser elaborados, adotados ou aplicados com intenção de criar obstáculos desnecessários ao comércio internacional;

- Devem se basear em metodologia científica que seja suficientemente cabal e abrangente para dar suporte às afirmações e que produza resultados precisos e reproduzíveis;

- As informações referentes aos procedimentos, metodologias e quaisquer critérios usados devem estar disponíveis e ser fornecidas a todas as partes interessadas sempre que solicitadas;

- O desenvolvimento deverá considerar todos os aspectos relevantes do ciclo de vida do produto;

- Não devem inibir inovações que mantenham ou tenham o potencial de melhorar o desempenho ambiental;

- Quaisquer requisitos administrativos ou demandas de informações devem ser limitados àqueles necessários para estabelecer a conformidade com os critérios e normas aplicáveis;

- Convém que o processo de desenvolvimento inclua uma consulta participatória e aberta às partes interessadas. Convém que sejam feitos esforços razoáveis para chegar a um consenso no decorrer do processo;

- As informações sobre aspectos ambientais dos produtos e serviços relevantes devem ser disponibilizadas aos compradores e potenciais compradores junto à parte que faz o rótulo ou declaração ambiental. (Ideia Sustentável, 2010b)

Importante ressaltar que grande parte dos estudos analisados prega a questão da importância da informação, mas muitas vezes em conjunto com a educação dos consumidores para utiliza-la, tendo esse tema sendo um dos programas iniciais identificados no Programa de 10 anos para Consumo e Produção Sustentáveis (em inglês, 10 Year Framework of Programmes - 10YFP), adotado durante a Rio+20 em 2012 (United Nations Environmental Programme - UNEP, 2015b). O objetivo deste programa é facilitar as escolhas dos consumidores por meio da disponibilização de informação sustentável pelos fornecedores, que conte com três atributos básicos: seja acessível, confiável e verificável, sendo esta última a que assegura a credibilidade da comunicação devido ao embasamento em dados científicos, feita de maneira consistente e facilmente compreendida por seus usuários. 


\subsubsection{As diferentes formas de classificar as ISP}

Conforme visto anteriormente, para determinar que o produto oferece uma diferenciação em termos ambientais, se faz necessário que esse atributo seja comunicado - o que deve ser feito por meio de um "apelo" de marketing (termo "claim", em inglês). Para Scammon e Mayer (1995), um apelo ambiental é uma declaração feita por uma empresa acerca do impacto de um ou mais de seus atributos de marca no meio ambiente (p.1-2). Para D’Souza (2004) e Gallastegui (2002) esses apelos podem ser feitos por meio de termos como "eco-amigável", “ambientalmente seguro", “ambientalmente amigável”, "reciclável”, "verde”, “biodegradável” e "ozônio amigável", dentre outros.

Segundo Bruce e Laroiya (2007) "selo verde" é um apelo feito por uma empresa que adotou formas ambientalmente corretas de produção e distribuição de seus bens e serviços, e é usualmente aplicado nos produtos no formato de um selo, mas também pode ser usado em propagandas ou apresentações de vendas. Em todos os casos, porém, este selo tem o objetivo de fornecer informações aos consumidores sobre os processos que a empresa adotou para proteger o meio ambiente (p.2). D’Souza (2004) usa um outro termo para o endosso de produtos ambientalmente corretos - "selo de informação ambiental", que, segundo a autora, pode ter a forma de símbolos, códigos, sinais ou textos escritos que os consumidores usam para identificar tais produtos (p. 6-7).

Já as definições de Gertz (2005) e Rubik, Scheer, e Iraldo (2008) adicionam a questão da compar4abilidade, defendendo que um selo verde promove produtos e serviços que tenham impacto ambiental menor que os seus concorrentes. Gertz (2005) ressalta, ainda, que este é um método voluntário de certificação e rotulagem da performance ambiental (p.1) e Rubik et al. (2008) relacionam impactos também relacionados à saúde e consumo de recursos, além do impacto no meio ambiente. Vale pontuar que a afirmação sobre a superioridade do produto com selo não pode ser considerada verdadeira, dado que um produto sem selo pode ter performance superior a um com selo, mas não ter recorrido à uma certificação para medir e/ou comunicar tal conquista, seja por falta de conhecimento, por uma questão de custo ou por não estar em sua estratégia de negócios, dentre outras motivações.

\footnotetext{
${ }^{2}$ Tradução para o termo em inglês "ozone friendly".
} 
McAllister (2009) corrobora com as definições acima mencionadas e comenta que podem ser dois os principais objetivos dos selos verdes: i) por meio da disponibilização de informação, encorajar uma mudança rumo a um consumo ambientalmente responsável; e ii) estimular produtores e outros participantes do mercado a aprimorar os padrões ambientais de produtos e serviços. Um outro atributo que ser considerados ao se conceituar a rotulagem ambiental se refere a contribuição ao processo de compra dos consumidores, considerando não somente a seleção de produtos, mas também sua compra, uso e descarte (US Environmental Protection Agency [EPA], 1998, p.23).

A Agência de Proteção Ambiental americana (Environmental Protection Agency - EPA) destaca que o fator mais importante a ser considerado quando da avaliação de programas de rotulagem ambiental se refere à questão da verificação do mesmo, podendo ser um programa auto-declarado, no qual a própria empresa destaca os atributos ambientais positivos de seus produtos, ou um programa verificado por terceiros, no qual uma fonte independente concede o direito de uso de um selo com base em critérios ou padrões ambientais (vide Figura 1).

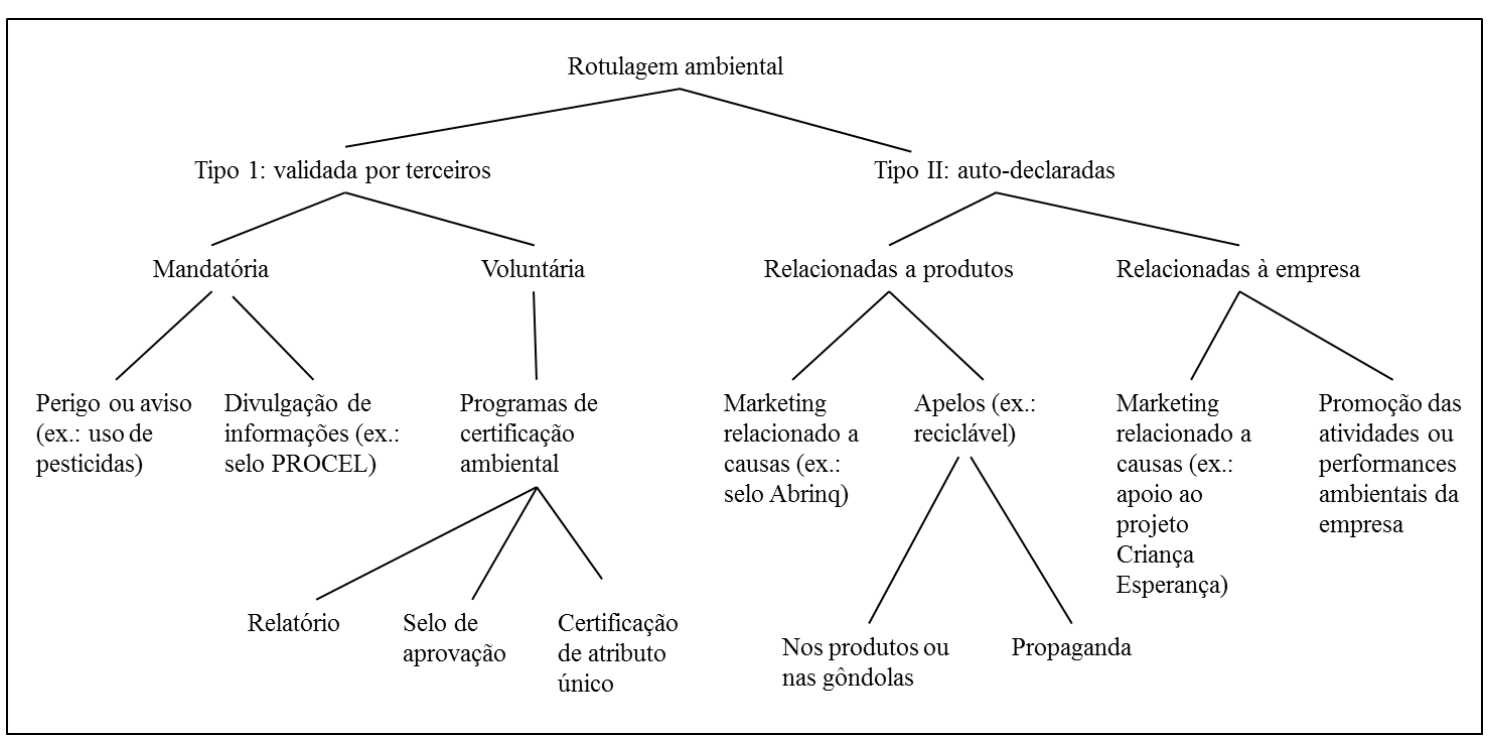

Figura 1 - Classificação da rotulagem ambiental nos Estados Unidos

Fonte: EPA, 2008. Traduzido e adaptado pela autora em relação aos exemplos citados.

Este também é o critério utilizado pela International Standardization Organization (ISO) para classificar a rotulagem ambiental, aplicado na norma ISO 14020 ("rótulos e declarações ambientais"), com o objetivo de padronizar os princípios, práticas e características-chave 
relacionadas a rotulagem ambiental. Esta norma diferencia as declarações ambientais em três categorias diferentes, a saber:

- Tipo I: autorização do uso de selos ambientais em produtos obtida a partir de uma avaliação voluntária com base em múltiplos critérios, realizada por um terceiro;

- Tipo II: apelos ambientais informativos auto-declarados pelos produtores, importadores e/ou distribuidores, relacionados a atributos específicos dos produtos, como o fato de ser reciclável, ou feito de material reciclado;

- Tipo III: programas voluntários que geram dados quantificáveis sobre impacto dos produtos, com base em estudos de $\mathrm{ACV}$, verificados por terceiros (Compromisso Empresarial para Reciclagem [CEMPRE] \& Associação Brasileira de Embalagem [ABRE], n.d.; Global Ecolabelling Network [GEN], 2004).

De forma geral, a maioria dos autores defende a rotulagem tipo I como a mais confiável, dado que é a ferramenta que oferece maior credibilidade da informação que está sendo transmitida, pelo fato de ser certificada por terceiros (Gallastegui, 2002; Rubik et al., 2008; Thøgersen, 2000; Van Amstel et al., 2008). A Global Ecolabelling Network (GEN), instituição não-governamental criada com intuito de melhorar, promover e desenvolver o uso de certificações sustentáveis em produtos e serviços, também defende a certificação, citando em sua definição de "selo verde" que

[...] é um selo que identifica preferência ambiental de um produto (bem ou serviço) dentro de uma categoria, baseado em considerações sobre seu ciclo de vida. Em contraste com um símbolo próprio ou apelo desenvolvido pelo produtor ou fornecedor de serviço, um selo verde é atribuído por um terceiro imparcial a produtos que satisfazem a critérios ambientais estabelecidos no mercado" (Global Ecolabelling Network - GEN, 2004).

Em relação a outras formas de classificação das certificações, foi possível encontrar um relatório de pesquisa realizado pela empresa SustainAbility em que é apresentada uma proposta que menciona a existência de três mecanismos diferentes que, frequentemente, mas não sempre, são utilizados em conjunto: i) padrões definem requerimentos a serem seguidos pelos participantes de uma programa, geralmente estabelecidos com uma abordagem consensual; ii) certificação fornece a garantia de uma terceira parte de que um produto, processo ou serviço, está em conformidade com certos padrões; e iii) selos provêm apelos, 
logotipos ou ícones estampados nas embalagens, que indicam conformidade com um padrão (Potts, Van der Meer \& Daitchman, 2010, conforme citado em SustainAbility, 2011, p.12)

Os programas de rotulagem ambiental podem também ser caracterizados como positivos, negativos ou neutros. Os positivos certificam produtos que possuem um ou mais atributos positivos, indicando qual produto é ambientalmente mais correto dentre diversos produtos similares; os negativos alertam os consumidores sobre perigos ou ingredientes prejudiciais contidos nos produtos; e os neutros simplesmente sintetizam as informações ambientais dos produtos para que os consumidores possam considera-las em sua decisão de compra, tendo a oportunidade de julgar a performance ambiental do produto de acordo com suas prioridades individuais (EPA, 1998). Segundo relatório da UNEP de 2015 (UNEP, 2015a), a maioria das ferramentas existentes de ISP são do tipo neutras, sendo que a organização defende que este não é o modelo ideal, dado que deixa para que o consumidor tire suas próprias conclusões acerca do que está sendo comunicado, e considerando que ele nem sempre está preparado para fazer isso.

Em seu levantamento, Hartlieb e Jones (2009) puderam agrupar os apelos encontrados em três principais áreas de atuação: i) ambiental, que incluía questões como biodiversidade, qualidade do solo, gestão sustentável de recursos; ii) justiça social, que envolve temas como comércio justo, direitos humanos e do trabalho e questões de desenvolvimento; e iii) bem estar animal. Os autores citam que alguns dos selos eram focados em apenas uma área de atuação específica, enquanto outros endereçavam mais de uma área de atuação. Nilsson, Tunçer, e Thidell (2004) comentam sobre essa diversidade de iniciativas, que pode incluir bem estar dos animais, saúde e ética, dentre outros, além das métricas que atuam em diversas direções, mas sendo que todas acabam por usar o mesmo apelo de serem "ambientalmente amigável".

Esta diferença em relação ao número de áreas de atuação dos selos é registrada por Golden (2010, p.13), que sugere dois tipos de certificações ambientais: i) de atributo simples, que são relacionados com apenas uma característica ambiental, como eficiência energética ou conteúdo reciclável; e ii) de atributos múltiplos, que avalia os produtos em relação a uma série de impactos ambientais, geralmente ao fazer uma análise dos estágios do seu ciclo de vida. O autor comenta que os selos de atributos simples são criticados por falharem no desafio de definir a intensidade e/ou qualidade do benefício ambiental que ele 
entrega, dado que é difícil comparar dois selos diferentes de atributos simples, pois cada um avalia uma característica específica. No entanto, o autor defende que o fato de considerar apenas um atributo faz este tipo de selo ser melhor compreendido pelos consumidores, aplicado a produtos de diversas indústrias e mais aceito pelos varejistas.

Bhaskaran et al. (2006) consolida diversas referências mostrando que a classificação das certificações ambientais pode capturar uma ampla gama de situações. Os apelos podem ser específicos ao uso do produto (por exemplo, "não produzem gases de efeito estufa"), à sua matéria-prima (por exemplo, "feitos com materiais reciclados"), ao processo de produção (por exemplo, "orgânico"). Ressalta-se que, para a European Commission (2014), um apelo sustentável é considerado claro quando não há dúvida para o consumidor médio: i) que o apelo abrange todo o produto ou apenas um dos seus componentes; ii) que o apelo se refere à empresa como um todo (aplicável a todos os seus produtos) ou apenas a determinados produtos; e iii) sobre qual o estágio do ciclo de vida ou das características do produto que o apelo abrange exatamente.

Após levantamento e análise dos conceitos apresentados, chegou-se à consolidação apresentada na Tabela 2, que divide os tipos de certificações que buscam analisar as seguintes características: empresas, produto como um todo, parte do produto (conteúdo ou embalagem) e processo produtivo e/ou comercialização. Nota-se que em todas estas definiçõos existe sobreposição em relação aos diversos termos utilizados para determinar as rotulagens ambientais. Como exemplo, o conceito de "selo" de Bruce e Laroiya (2007) é o mesmo aplicado por Scammon e Mayer (1995) para "apelo" - uma declaração feita pela empresa para comunicar atributos ambientalmente corretos de seu processo produtivo. Além disso, há diferentes tipos de rotulagem relacionados às três dimensões da sustentabilidade, principalmente com viés ambiental e social, sendo que diversas denominações também são utilizadas para se referir a eles, como "selos", "declarações", "rotulagens", “apelos", etc. e a integração entre as três dimensões (social, ambiental e econômica) ainda é rara. 
Tabela 2 - Proposta de classificação das certificações

\begin{tabular}{|l|l|}
\hline Tipo de selo & Exemplos \\
\hline Empresa & $\begin{array}{l}\text { B Corp } \\
\text { ISO } \\
\text { Leed }\end{array}$ \\
\hline Produto como um todo & $\begin{array}{l}\text { Pegada de carbono } \\
\text { Pegada hídrica } \\
\text { Cradle to cradle } \\
\text { Eficiência energética }\end{array}$ \\
\hline $\begin{array}{l}\text { Parte do produto } \\
\text { (conteúdo ou embalagem) }\end{array}$ & $\begin{array}{l}\text { FSC (manejo e cadeia de custódia) } \\
\text { I'm Green } \\
\text { Orgânico }\end{array}$ \\
\hline $\begin{array}{l}\text { Processo produtivo e/ou } \\
\text { comercialização }\end{array}$ & $\begin{array}{l}\text { Orgânico trade } \\
\text { Friend of the sea } \\
\text { FSC (cadeia de custódia) } \\
\text { Rainforest Alliance }\end{array}$ \\
\hline Fonte: proposto pela autora com base nas classificações apresentadas.
\end{tabular}

Fonte: proposto pela autora com base nas classificações apresentadas.

Para facilitar a leitura do presente trabalho, utilizar-se-á o termo "sustentável” para cobrir programas que envolvam uma ou mais das três dimensões da sustentabilidade (social, ambiental e/ou econômica). Buscou-se também aplicar uma forma de organização das denominações, com base na revisão bibliográfica realizada e nas traduções dos termos do inglês para o português realizadas pela autora. Com isso, a organização dos termos relacionados à rotulagem sustentável será feita da seguinte maneira (vide Figura 2): "rotulagem sustentável" será considerado o conceito mais amplo relacionado à inserção de informações sustentáveis nas embalagens de produtos, o que abrange inclusive dados mandatórios; "apelo sustentável" envolve qualquer tipo de mensagem utilizada para ressaltar a informação relativa a um diferencial sustentável de produto com objetivo de buscar diferenciação de mercado; dentre os apelos sustentáveis estão o "selo sustentável” e a “certificação sustentável”, que farão referência à qualquer símbolo, código, sinal, ícone, tabela, imagem ou logotipo para aplicação nas embalagens dos produtos com objetivo de chamar a atenção para os apelos sustentáveis, sendo que "selo sustentável" está relacionado à

\footnotetext{
${ }^{3}$ Mais informações sobre estas certificações podem ser encontradas no tópico seguinte: 2.1 .5 - Rotulagem sustentável no Brasil.
} 
rotulagem tipo II (auto-declaradas) e “certificação sustentável” está relacionada à rotulagem tipo I (com verificação por terceiros).

Rotulagem sustentável

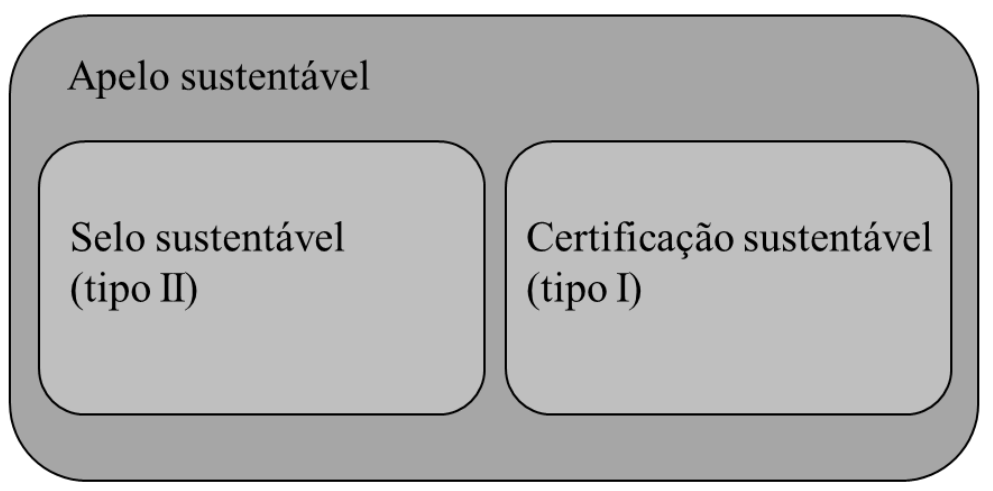

Figura 2 - Organização dos termos para o presente trabalho Fonte: elaborado pela autora.

\subsubsection{Rotulagem sustentável no Brasil}

Apesar da existência de diversas certificações sustentáveis no país e do maior engajamento de diferentes níveis da sociedade com o consumo sustentável (Barbosa, Portilho, Wilkinson, \& Dubeux, 2014), conforme visto anteriormente, o Brasil ainda tem poucos estudos acerca do tema. Kohlrausch, Campos, e Selig (2004), por exemplo, buscaram identificar e caracterizar a relação do consumidor de produtos orgânicos de supermercado com o selo ambiental, por meio de pesquisa exploratória envolvendo levantamento bibliográfico e pesquisa de campo, aplicada por meio de questionário. Os autores constataram a falta de conhecimento dos consumidores em relação às certificações orgânicas, sendo que os consumidores não conseguiam identifica-las, nem dizer o que significavam. Porém, ressaltouse uma valorização da mesma na hora da compra, com maior credibilidade quando a certificação for realizada por terceiros.

O estudo de Coltro e Kruglianskas (2006) teve como objetivo identificar a utilidade para uso e consumo, do ponto de vista do comprador, dos selos de certificação de qualidade assegurada constantes dos rótulos de produtos, além de verificar se consumidores conscientes 
que identificassem tais selos conseguiam decodificar seu significado. Por meio da análise descritiva dos dados de 50 respondentes, estudantes da Universidade de São Paulo, os autores concluíram que os mesmos possuíam um alto grau de consciência socioambiental mas, em sua maioria, não conseguiam identificar as certificações, associando a elas uma utilidade de caráter mercadológico, em busca de diferenciação de mercado.

Já o estudo de Deus, Felizola, e Silva (2010) identificou e descreveu as principais certificações socioambientais do Brasil, demonstrando seu potencial de influenciar o comportamento dos consumidores. Realizado com base em revisão bibliográfica, levantou-se que os consumidores possuem pouca informação sobre estas certificações, sendo que a sua obtenção e domínio são divulgadas de uma forma tímida e confusa, o que pode ocasionar comparações com selos sem credibilidade. Hamza e Dalmarco (2012) e, mais recentemente, Gomes e Júnior (2016) também procuraram levantar o quanto os consumidores identificam e compreendiam os significados das certificações sustentáveis, concluindo que faltavam aos consumidores conhecimentos básicos sobre os apelos sustentáveis: o que são, para que servem, quais existem e o que significam.

Segundo Voltolini (2010), no Brasil o alto índice de desinformação acerca do comportamento socioambiental de produtos e empresas se deve a dois fatores principais: i) baixo valor de importância atribuído pelo consumidor ao tema socioambiental como critério de compra que, segundo o autor, é um desafio de natureza cultural e valorativa; e ii) escassez de informação socioambiental nos produtos ou mesmo dificuldade de identificar e decodificar as poucas informações existentes pela falta de indicadores específicos, rótulos explicativos e campanhas de comunicação de empresas baseadas nos atributos sociais e ambientais de seus produtos.

Para a CEMPRE, a tendência no país é a de utilização cada vez mais ampla das autodeclarações ambientais, buscando oferecer informações precisas, relevantes e de fácil entendimento para o consumidor, seja ele o consumidor final ou mesmo na relação B2B (business to business). De acordo com a instituição, não há relatos de programas de selo verde que tenham ganhado relevância em cenários nacionais ou mesmo regionais (ex.: Mercosul) exceto no caso do setor de papel e celulose e suas florestas de replantio (CEMPRE, n.d.). Importante ressaltar que não há citação e/ou referências de como se chegou a tal conclusão, porém acredita-se, como será apresentado a seguir, que exista alguma fragilidade nessa 
comunicação, dada a existência de diversas certificações sustentáveis atualmente no mercado nacional.

Para se obter uma maior compreensão do tamanho e variedade do mercado dos apelos sustentáveis no país, buscou-se fazer um mapeamento dos mesmos. Um primeiro levantamento já havia sido realizado pela autora (Hamza \& Dalmarco, 2012), sendo que o mesmo foi atualizado e ampliado via pesquisa de dados secundários - seja na busca de produtos no varejo supermercadista, seja via pesquisa na internet (sites de busca, das certificadoras, e em notícias publicados em meio eletrônico, assim como de informações na mídia em geral). O resultado foi a identificação de 21 certificações (tipo I) internacionais e 29 nacionais, que foram organizados nas Tabelas 3 e 4, respectivamente, em ordem alfabética da instituição responsável pelas mesmas. Na Tabela 5 são listados alguns selos (tipo II), organizados em ordem alfabética da empresa fabricante do produto.

A classificação foi feita com base no trabalho de Hartlieb e Jones (2009) e adaptada pela autora, com a inclusão do tipo da instituição responsável (ONG, empresa ou Governo) na segunda coluna, e o tipo de selo na quinta coluna, conforme proposta de classificação citada na Tabela 2 do presente trabalho (página 36). As informações da tabela ficaram, então, organizadas da seguinte maneira:

- $\quad$ Logo do selo;

- Instituição responsável pelo selo e seu tipo (ONG, empresa de capital privado ou Governo);

- $\quad$ O que ele significa (em linhas gerais);

- $\quad$ Área de atuação: ambiental (inclui energia), social (inclui saúde e qualidade) e/ou econômica;

- Categorias de produtos em que são aplicáveis: agricultura, alimentos, eletroeletrônicos, moda, cosméticos, entre outros. Se for aplicável a mais de 3 categorias foi classificado como "diversos".

- $\quad$ Tipo de selo: empresa, produto como um todo, parte do produto (embalagem ou conteúdo) ou processo produtivo e/ou de comercialização (que será abreviado para "comercial"). 
Faz-se importante ressaltar que esta sistematização depende da qualidade das informações disponibilizadas pelas organizações responsáveis. Todos os selos expostos nas Tabelas 3 e 4 têm suas respectivas páginas na internet (listadas no Apêndice A), com profundidade e clareza variáveis. Alguns têm informações completas, com documentos explicando o processo de certificação e as variáveis analisadas. Outros explicam de maneira bem generalizada o objetivo da certificação, sem deixar claro o que elas abrangem e como funciona o esquema de padronização. Esta é a continuidade de um esforço realizado pela primeira vez em 2012 a fim de se ter uma maior clareza do contexto da certificação no Brasil (Hamza \& Dalmarco, 2012), sendo que certamente há espaço para novas contribuições a fim de aperfeiçoá-lo. O objetivo não foi levantar $100 \%$ dos apelos sustentáveis existentes no Brasil atualmente, mas sim apresentar uma amostra dos selos e certificações mais relevantes por número de apresentação em produtos encontrados no varejo supermercadista, ou relevância nas páginas de busca pela internet. Não foram considerados os selos específicos sobre embalagens recicladas ou recicláveis, devido à grande diversidade de formas de apresentação destas informações.

Tabela 3 - Certificações sustentáveis internacionais presentes no Brasil (não exaustivo)

(continua)

\begin{tabular}{|c|c|c|c|c|c|}
\hline Logo & Responsável & O que significa & Atuação & Categorias & Tipo de selo \\
\hline C: & $\begin{array}{l}\text { Carbon Trust } \\
\text { Inglaterra } \\
(\mathrm{ONG})\end{array}$ & $\begin{array}{l}\text { Confere medição e plano } \\
\text { para alcançar reduções e } \\
\text { compensação usando } \\
\text { créditos de carbono de alta } \\
\text { qualidade. }\end{array}$ & $\begin{array}{l}\text { Meio } \\
\text { ambiente, } \\
\text { sociedade e } \\
\text { economia }\end{array}$ & Diversos & $\begin{array}{l}\text { Produto como } \\
\text { um todo }\end{array}$ \\
\hline $\begin{array}{l}\text { CARBON } \\
\text { TRUST } \\
\text { OOOO }\end{array}$ & $\begin{array}{l}\text { Carbon Trust } \\
\text { Inglaterra } \\
(\mathrm{ONG})\end{array}$ & $\begin{array}{l}\text { Busca calcular a água } \\
\text { consumida ao longo de todo } \\
\text { o ciclo de vida de um } \\
\text { produto ou serviço. }\end{array}$ & $\begin{array}{l}\text { Meio } \\
\text { ambiente }\end{array}$ & Diversos & $\begin{array}{l}\text { Produto como } \\
\text { um todo }\end{array}$ \\
\hline
\end{tabular}

Cradle to

Cradle

Products

Avalia o processo de

Meio

Innovation melhoria contínua que envolve o produto e sua

ambiente e Diversos sociedade

Produto como fabricação.

um todo

(ONG)

Earth Island

Institute

(ONG)
Trabalha com os pescadores para evitar e reduzir as capturas de golfinhos durante pesca de atum.

$\begin{array}{lll}\begin{array}{l}\text { Meio } \\ \text { ambiente }\end{array} & \begin{array}{l}\text { Alimentos } \\ \text { (atum) }\end{array} & \begin{array}{l}\text { Processo } \\ \text { produtivo }\end{array}\end{array}$


(continuação)

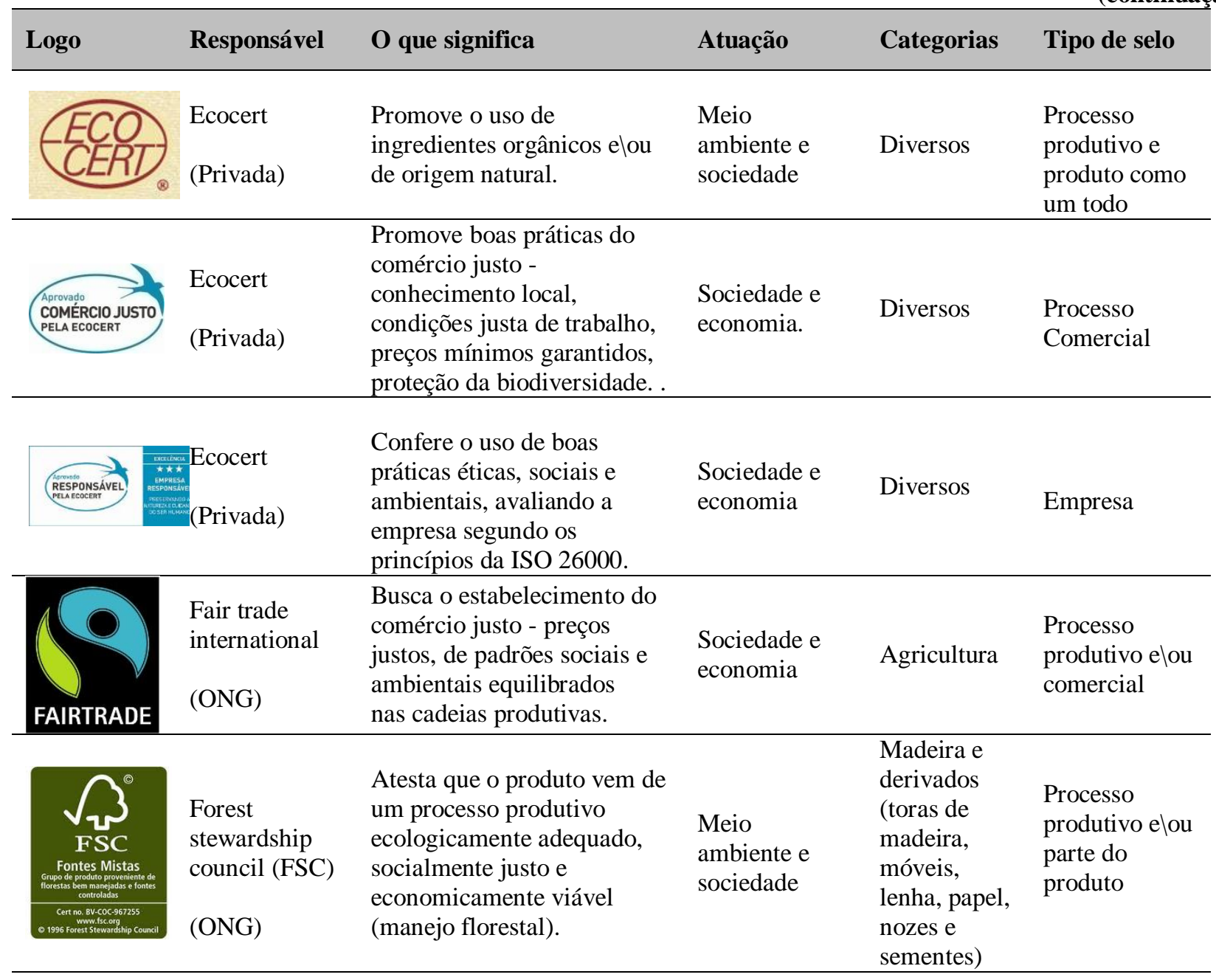

\begin{tabular}{|c|c|c|c|c|c|}
\hline . & $\begin{array}{l}\text { Friend of the } \\
\text { sea } \\
\text { (ONG) }\end{array}$ & $\begin{array}{l}\text { Certifica produtos de pesca e } \\
\text { aquicultura sustentáveis com } \\
\text { o objetivo de conservar o } \\
\text { habitat marinho. }\end{array}$ & $\begin{array}{l}\text { Meio } \\
\text { ambiente }\end{array}$ & $\begin{array}{l}\text { Alimentos } \\
\text { (pesca e } \\
\text { aquicultura) }\end{array}$ & $\begin{array}{l}\text { Processo } \\
\text { produtivo elou } \\
\text { comercial }\end{array}$ \\
\hline $\begin{array}{l}\text { CERTIFIED } \\
\text { HUMANE } \\
\text { BEM-ESTAR ANIMAL }\end{array}$ & $\begin{array}{l}\text { Humane farm } \\
\text { animal care } \\
\text { (ONG) }\end{array}$ & $\begin{array}{l}\text { Assegura práticas mais } \\
\text { amáveis e responsáveis com } \\
\text { os animais, desde o } \\
\text { nascimento até o abate. }\end{array}$ & $\begin{array}{l}\text { Segurança } \\
\text { alimentar e } \\
\text { meio ambiente }\end{array}$ & $\begin{array}{l}\text { Alimentos } \\
\text { agrícolas }\end{array}$ & $\begin{array}{l}\text { Processo } \\
\text { produtivo }\end{array}$ \\
\hline der & $\begin{array}{l}\text { IBD } \\
\text { Certificações } \\
(\mathrm{ONG})\end{array}$ & $\begin{array}{l}\text { Certifica produtos } \\
\text { provenientes da agricultura } \\
\text { biodinâmica. }\end{array}$ & $\begin{array}{l}\text { Meio } \\
\text { ambiente e } \\
\text { sociedade }\end{array}$ & $\begin{array}{l}\text { Diversos } \\
\text { (vinícola, } \\
\text { alimentos, } \\
\text { agricultura) }\end{array}$ & $\begin{array}{l}\text { Processo } \\
\text { produtivo e } \\
\text { produto como } \\
\text { um todo. }\end{array}$ \\
\hline & $\begin{array}{l}\text { Japan } \\
\text { Agricultural } \\
\text { Standarts } \\
\text { (Governo) }\end{array}$ & $\begin{array}{l}\text { Assegura padrões para } \\
\text { produtos animais e } \\
\text { alimentos orgânicos. }\end{array}$ & $\begin{array}{l}\text { Meio } \\
\text { ambiente e } \\
\text { sociedade }\end{array}$ & Diversos & $\begin{array}{l}\text { Processo } \\
\text { produtivo e } \\
\text { produto como } \\
\text { um todo. }\end{array}$ \\
\hline
\end{tabular}


(continuação)

\begin{tabular}{|c|c|c|c|c|c|}
\hline Logo & Responsável & O que significa & Atuação & Categorias & Tipo de selo \\
\hline & $\begin{array}{l}\text { Leadership in } \\
\text { Energy and } \\
\text { Environmental } \\
\text { Design } \\
\text { (LEED) } \\
\text { (ONG) }\end{array}$ & $\begin{array}{l}\text { Estipula padrões para a } \\
\text { construção sustentável - } \\
\text { materiais renováveis, } \\
\text { sistemas que economizem } \\
\text { energia elétrica, água e gás e } \\
\text { controle da poluição. }\end{array}$ & $\begin{array}{l}\text { Meio } \\
\text { ambiente e } \\
\text { sociedade }\end{array}$ & $\begin{array}{l}\text { Construção } \\
\text { civil }\end{array}$ & Empresa \\
\hline
\end{tabular}

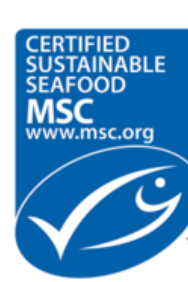

Marine

Stewardship

Council

Estabelece padrão para a

Meio pesca sustentável.

ambiente e

sociedade

Alimentos
(marinhos)

Processo

produtivo elou

comercial

(ONG)

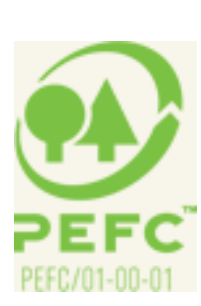

Programme

for the

Endorsement

of Forest

Certification

Atesta que o produto vem de

um processo produtivo

ecologicamente adequado,

socialmente justo e

economicamente viável

\section{Meio}

ambiente e

sociedade

(marinhos)

Madeira e derivados

Processo produtivo elou parte do produto

$(\mathrm{ONG})$

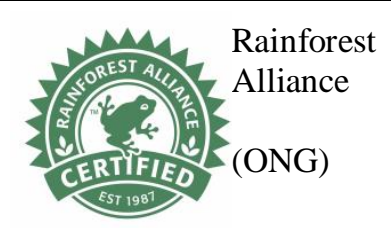

Garante o respeito pela biodiversidade e pelos trabalhadores envolvidos com a atividade produtiva.
Meio

ambiente e

sociedade
Agricultura,

turismo,

madeira e

derivados
Processo produtivo elou comercial

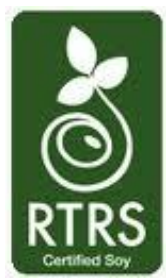

Round Table

on

Responsible

Soy

(ONG)
Promove a produção, processamento e comercialização responsável da soja, na forma de matéria-prima ou subproduto, em nível global.
Meio

ambiente,

sociedade e

economia
Agricultura

(produtos

alimentícios,

bicombustív

eis)

Processo

produtivo elou

comercial

\begin{tabular}{|c|c|c|c|c|c|}
\hline SP & $\begin{array}{l}\text { Roundtable on } \\
\text { sustainable } \\
\text { palm oil } \\
\text { (ONG) }\end{array}$ & $\begin{array}{l}\text { Estabelece critérios } \\
\text { ambientais e sociais para } \\
\text { produção, processamento e } \\
\text { comercialização de óleo de } \\
\text { palma de forma sustentável. }\end{array}$ & $\begin{array}{l}\text { Meio } \\
\text { ambiente, } \\
\text { sociedade e } \\
\text { economia }\end{array}$ & Agricultura & $\begin{array}{l}\text { Processo } \\
\text { produtivo elou } \\
\text { comercial }\end{array}$ \\
\hline & $\begin{array}{l}\text { United States } \\
\text { department of } \\
\text { agriculture } \\
\text { (Governo) }\end{array}$ & $\begin{array}{l}\text { Avalia se a produção ou o } \\
\text { manejo está em } \\
\text { conformidade com a Lei de } \\
\text { Produção de Alimentos } \\
\text { Orgânicos, estabelecida } \\
\text { pelos EUA... }\end{array}$ & $\begin{array}{l}\text { Meio } \\
\text { ambiente e } \\
\text { sociedade }\end{array}$ & Diversos & $\begin{array}{l}\text { Processo } \\
\text { produtivo e } \\
\text { produto como } \\
\text { um todo. }\end{array}$ \\
\hline
\end{tabular}

Fonte: informações obtidas nos sites das instituições e compiladas pela autora. 
$\mathrm{Na}$ Tabela 4 foram listadas as certificações com origem brasileira.

Tabela 4 - Certificações sustentáveis com origem brasileira (não exaustivo)

(continua)

\begin{tabular}{|c|c|c|c|c|c|}
\hline Logo & Responsável & O que significa & Atuação & Categorias & Tipo de selo \\
\hline $\begin{array}{l}\text { ORIGEEMM } \\
\text { SUSTENTÁVEL }\end{array}$ & $\begin{array}{l}\text { Abicalçados e } \\
\text { Assintecal } \\
(\mathrm{ONG})\end{array}$ & $\begin{array}{l}\text { Reconhece as empresas } \\
\text { brasileiras que já } \\
\text { incorporaram a } \\
\text { sustentabilidade em seus } \\
\text { processos produtivos. }\end{array}$ & $\begin{array}{l}\text { Meio ambiente e } \\
\text { sociedade }\end{array}$ & Calçados & $\begin{array}{l}\text { Processo } \\
\text { produtivo }\end{array}$ \\
\hline & $\begin{array}{l}\text { Associação } \\
\text { brasileira de } \\
\text { normas } \\
\text { técnicas } \\
\text { (ONG) }\end{array}$ & $\begin{array}{l}\text { Leva em conta a redução } \\
\text { de impactos negativos } \\
\text { causados no meio } \\
\text { ambiente em todas as } \\
\text { etapas do ciclo de vida de } \\
\text { um produto ou serviço, } \\
\text { conforme normas. }\end{array}$ & $\begin{array}{l}\text { Meio ambiente e } \\
\text { sociedade }\end{array}$ & Diversos & $\begin{array}{l}\text { Produto } \backslash \\
\text { serviço } \\
\text { como um } \\
\text { todo }\end{array}$ \\
\hline & $\begin{array}{l}\text { Associação de } \\
\text { agricultura } \\
\text { natural de } \\
\text { Campinas e } \\
\text { região (ANC) } \\
(\mathrm{ONG}) \\
\end{array}$ & $\begin{array}{l}\text { Certifica produtos } \\
\text { orgânicos produzidos e } \\
\text { processados dentro de } \\
\text { normas que garantem aos } \\
\text { consumidores a origem e o } \\
\text { tipo de produção. }\end{array}$ & $\begin{array}{l}\text { Meio ambiente e } \\
\text { sociedade }\end{array}$ & Diversas & $\begin{array}{l}\text { Processo } \\
\text { produtivo e } \\
\text { produto } \\
\text { como um } \\
\text { todo. }\end{array}$ \\
\hline & $\begin{array}{l}\text { Braskem } \\
\text { (Privada) }\end{array}$ & $\begin{array}{l}\text { Identifica que o plástico } \\
\text { foi produzido com matéria } \\
\text { prima renovável e } \\
\text { sustentável (cana de } \\
\text { açúcar) }\end{array}$ & Meio ambiente & $\begin{array}{l}\text { Embalagens } \\
\text { plásticas }\end{array}$ & $\begin{array}{l}\text { Parte do } \\
\text { produto }\end{array}$ \\
\hline & $\begin{array}{l}\text { Eletrobras } \\
\text { (Governo) }\end{array}$ & $\begin{array}{l}\text { Destaca os produtos que } \\
\text { apresentam os melhores } \\
\text { níveis de eficiência } \\
\text { energética dentro de cada } \\
\text { categoria. }\end{array}$ & $\begin{array}{l}\text { Meio ambiente e } \\
\text { sociedade }\end{array}$ & $\begin{array}{l}\text { Diversos } \\
\text { (eletro- } \\
\text { eletrônicos) }\end{array}$ & $\begin{array}{l}\text { Parte do } \\
\text { produto }\end{array}$ \\
\hline $\mathrm{AX} / \mathrm{u}$ & $\begin{array}{l}\text { Grupo } \\
\text { SustentaX } \\
\text { (Privada) }\end{array}$ & $\begin{array}{l}\text { Identifica produtos, } \\
\text { materiais, equipamentos e } \\
\text { serviços dentro das normas } \\
\text { ambientais da ISO } 14024 \text { - } \\
\text { avalia os atributos } \\
\text { essenciais, } \\
\text { complementares e } \\
\text { suplementares da } \\
\text { sustentabilidade. }\end{array}$ & $\begin{array}{l}\text { Meio ambiente, } \\
\text { sociedade e } \\
\text { economia }\end{array}$ & $\begin{array}{l}\text { Diversos } \\
\text { (empresas, } \\
\text { construtoras) }\end{array}$ & $\begin{array}{l}\text { Produto } \\
\text { como um } \\
\text { todo }\end{array}$ \\
\hline & $\begin{array}{l}\text { IBD } \\
\text { Certificações } \\
\text { (Privada) }\end{array}$ & $\begin{array}{l}\text { Garante propriedades } \\
\text { agrícolas e processos de } \\
\text { produção cultivados e/ou } \\
\text { processados de acordo com } \\
\text { as normas de produção } \\
\text { orgânicas e biodinâmicas. }\end{array}$ & $\begin{array}{l}\text { Meio ambiente e } \\
\text { sociedade }\end{array}$ & Diversos & $\begin{array}{l}\text { Processo } \\
\text { produtivo e } \\
\text { produto } \\
\text { como um } \\
\text { todo. }\end{array}$ \\
\hline
\end{tabular}


(continuação)

\begin{tabular}{|c|c|c|c|c|c|}
\hline Logo & Responsável & O que significa & Atuação & Categorias & Tipo de selo \\
\hline & $\begin{array}{l}\text { IBD } \\
\text { Certificações } \\
\text { (Privada) }\end{array}$ & $\begin{array}{l}\text { Indica que os processos de } \\
\text { desenvolvimento humano, } \\
\text { social e ambiental estão } \\
\text { fomentados por relações } \\
\text { comerciais baseadas nos } \\
\text { princípios do comércio } \\
\text { justo. }\end{array}$ & $\begin{array}{l}\text { Meio ambiente e } \\
\text { sociedade }\end{array}$ & $\begin{array}{l}\text { Produto não } \\
\text { agropecuário } \\
\text { (ex. água } \\
\text { mineral) }\end{array}$ & Comercial \\
\hline FR & $\begin{array}{l}\text { IBD } \\
\text { Certificações } \\
\text { (Privada) }\end{array}$ & $\begin{array}{l}\text { Indica que os processos de } \\
\text { desenvolvimento humano, } \\
\text { social e ambiental estão } \\
\text { fomentados por relações } \\
\text { comerciais baseadas nos } \\
\text { princípios do comércio } \\
\text { justo. }\end{array}$ & $\begin{array}{l}\text { Meio ambiente e } \\
\text { sociedade }\end{array}$ & $\begin{array}{l}\text { Produtos e } \\
\text { processos } \\
\text { certificados } \\
\text { como } \\
\text { orgânicos }\end{array}$ & Comercial \\
\hline & $\begin{array}{l}\text { IBD } \\
\text { Certificações } \\
\text { (Privada) }\end{array}$ & $\begin{array}{l}\text { Avalia o uso dos insumos } \\
\text { comerciais disponíveis no } \\
\text { mercado de acordo com as } \\
\text { principais diretrizes de } \\
\text { produção orgânica. }\end{array}$ & $\begin{array}{l}\text { Meio ambiente e } \\
\text { sociedade }\end{array}$ & $\begin{array}{l}\text { Agricultura, } \\
\text { pecuária e } \\
\text { alimentos }\end{array}$ & $\begin{array}{l}\text { Parte do } \\
\text { produto }\end{array}$ \\
\hline & $\begin{array}{l}\text { IBD } \\
\text { Certificações } \\
\text { (Privada) }\end{array}$ & $\begin{array}{l}\text { Comunica produtos que } \\
\text { não contém ou contém } \\
\text { dentro de limites pré- } \\
\text { estabelecidos, Organismo } \\
\text { Geneticamente } \\
\text { Modificados (OGM) }\end{array}$ & $\begin{array}{l}\text { Meio ambiente e } \\
\text { sociedade }\end{array}$ & $\begin{array}{l}\text { Diversos } \\
\text { (agricultura, } \\
\text { pecuária, } \\
\text { cosméticos) }\end{array}$ & $\begin{array}{l}\text { Produto } \\
\text { como um } \\
\text { todo }\end{array}$ \\
\hline INC & $\begin{array}{l}\text { IBD } \\
\text { Certificações } \\
\text { (Privada) }\end{array}$ & $\begin{array}{l}\text { Indica o uso de produtos e } \\
\text { processos com menor } \\
\text { impacto ambiental, sem } \\
\text { petroquímicos, com } \\
\text { matérias-primas } \\
\text { renováveis, de certificação } \\
\text { natural e orgânicas. }\end{array}$ & $\begin{array}{l}\text { Meio ambiente e } \\
\text { sociedade }\end{array}$ & $\begin{array}{l}\text { Cosméticos } \\
\text { e produtos } \\
\text { de limpeza }\end{array}$ & $\begin{array}{l}\text { Processo } \\
\text { produtivo e } \\
\text { parte do } \\
\text { produto }\end{array}$ \\
\hline $\begin{array}{l}\text { NEU } \\
\text { CARE } \\
\text { IBDN. }\end{array}$ & $\begin{array}{l}\text { Instituto } \\
\text { brasileiro de } \\
\text { defesa da } \\
\text { Natureza } \\
(\mathrm{ONG})\end{array}$ & $\begin{array}{l}\text { Indica que o impacto } \\
\text { ambiental foi minimizado } \\
\text { através da neutralização } \\
\text { de carbono com o plantio } \\
\text { de árvores nativas de Mata } \\
\text { Atlântica. }\end{array}$ & Meio ambiente & $\begin{array}{l}\text { Diversos } \\
\text { (instituição, } \\
\text { eventos, } \\
\text { empresas e } \\
\text { produtos) }\end{array}$ & $\begin{array}{l}\text { Produto } \\
\text { como um } \\
\text { todo }\end{array}$ \\
\hline
\end{tabular}

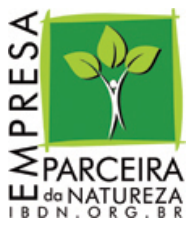

Instituto brasileiro de defesa da Natureza

Programa de gestão sócio ambiental que visa fomentar a consciência

Meio ambiente Diversos

(ONG) socioambiental da empresa

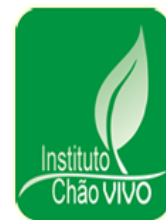

Instituto Chão

Vivo

(1)

Promove a agricultura de

base ecológica - produ
orgânicos - visando a proteção do agroecossistema e a

(ONG) qualidade de vida dos

Meio ambiente e sociedade

Diversas

Processo produtivo 
(continuação)

\begin{tabular}{|c|c|c|c|c|c|}
\hline Logo & Responsável & O que significa & Atuação & Categorias & Tipo de selo \\
\hline$\underbrace{0<1 / 0}_{\substack{\text { SELOECOLOGICO } \\
\text { FALCAO BAUER }}}$ & $\begin{array}{l}\text { Instituto } \\
\text { Falcão Bauer } \\
\text { (Privado) }\end{array}$ & $\begin{array}{l}\text { Demonstra o diferencial } \\
\text { ecológico do produto, } \\
\text { inclusive requisitos } \\
\text { relativos ao processo } \\
\text { produtivo. }\end{array}$ & Meio ambiente & Diversos & $\begin{array}{l}\text { Produto } \\
\text { como um } \\
\text { todo }\end{array}$ \\
\hline
\end{tabular}

$\begin{array}{llll}\text { Instituto } & \begin{array}{l}\text { Enquadra o produto em } \\ \text { uma categoria com } \\ \text { critérios ambientais } \\ \text { definidos, elaborados com } \\ \text { base em todas as fases do } \\ \text { ciclo de vida do produto. }\end{array} & \text { Meio ambiente } & \text { Diversos }\end{array}$

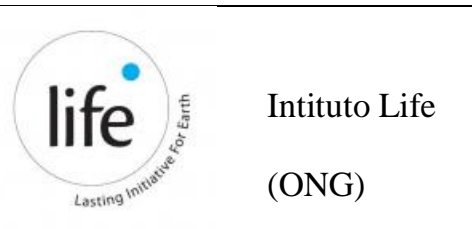

Avalia a gestão ambiental da organização com o objetivo de propor ações a serem realizadas para a obtenção da certificação.

Atesta que o produto vem de um processo produtivo ecologicamente adequado, socialmente justo e economicamente viável (manejo florestal).
Meio ambiente Diversos Empresa
Processo

produtivo elou parte do produto

(Governo)

\begin{tabular}{lll}
\hline & Instituto \\
& Nacional de \\
& Metrologia, \\
& Qualidade e \\
& & Tecnologia
\end{tabular}

(Governo)

\section{Confere aos produtos o} atendimento de requisitos de desempenho, conforme normas e regulamentos técnicos, principalmente quanto a sua eficiência energética.

$\begin{array}{lll}\begin{array}{l}\text { Meio ambiente e } \\ \text { sociedade }\end{array} & \text { Diversos } & \begin{array}{l}\text { Produto } \\ \text { como um } \\ \text { todo }\end{array}\end{array}$

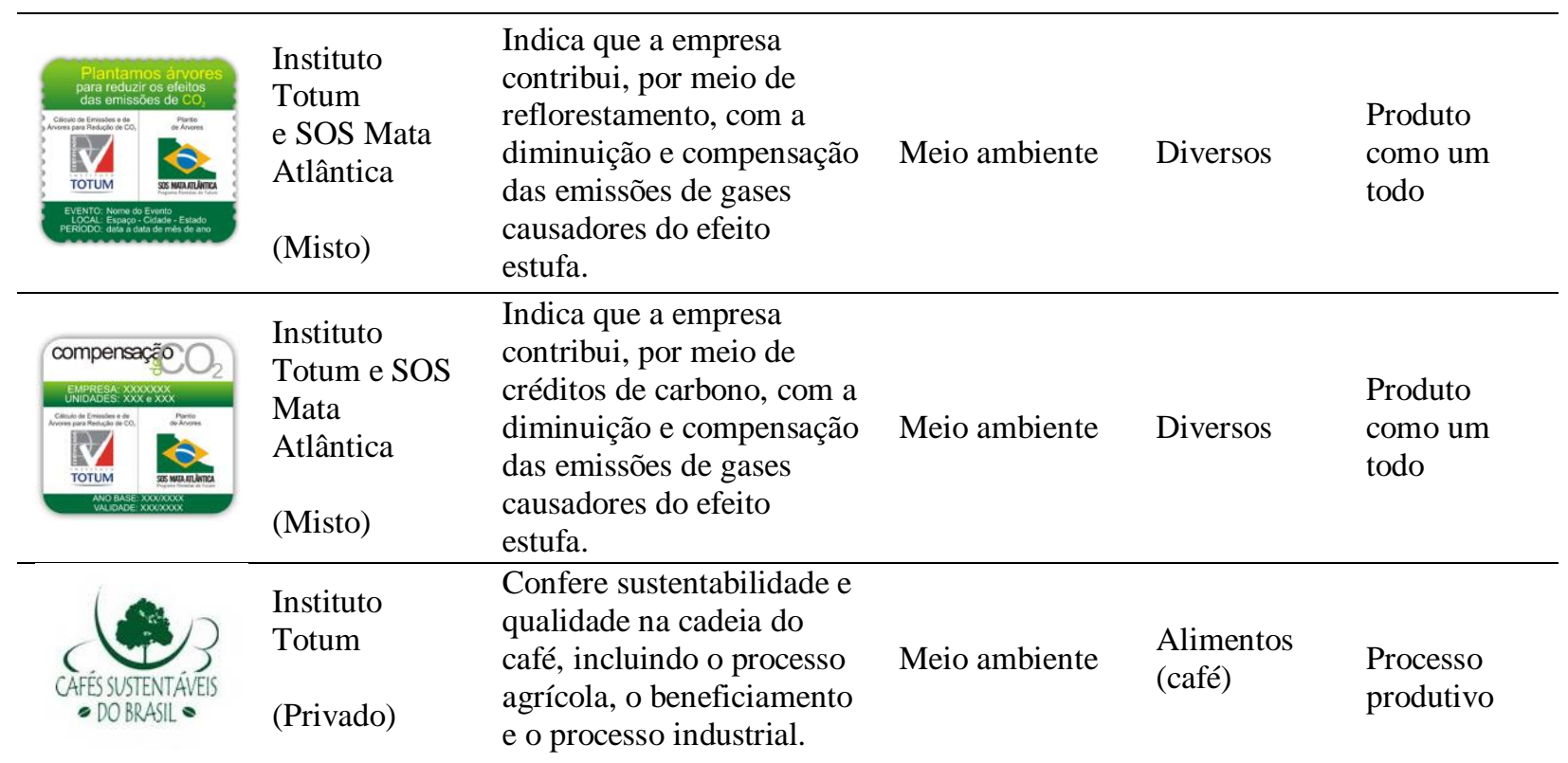


(conclusão)

\begin{tabular}{|c|c|c|c|c|c|}
\hline Logo & Responsável & O que significa & Atuação & Categorias & Tipo de selo \\
\hline 0 & $\begin{array}{l}\text { Max } \\
\text { ambiental }\end{array}$ & $\begin{array}{l}\text { Carbono Neutro devido a } \\
\text { compensações de emissões } \\
\text { de gases do efeito estufa } \\
\text { (GEE). }\end{array}$ & $\begin{array}{l}\text { Meio ambiente e } \\
\text { sociedade }\end{array}$ & Diversos & $\begin{array}{l}\text { Produto } \\
\text { como um } \\
\text { todo }\end{array}$ \\
\hline & $\begin{array}{l}\text { Ministério da } \\
\text { Agricultura, } \\
\text { Pecuária e } \\
\text { Abastecim/to } \\
\text { (Governo) } \\
\end{array}$ & $\begin{array}{l}\text { Estabelece normas para } \\
\text { regular a produção, o } \\
\text { processamento e a } \\
\text { comercialização de } \\
\text { produtos orgânicos. }\end{array}$ & $\begin{array}{l}\text { Meio ambiente e } \\
\text { sociedade }\end{array}$ & $\begin{array}{l}\text { Alimentos, } \\
\text { agronegócio, } \\
\text { cosméticos }\end{array}$ & $\begin{array}{l}\text { Processo } \\
\text { produtivo e } \\
\text { produto } \\
\text { como um } \\
\text { todo. }\end{array}$ \\
\hline & $\begin{array}{l}\text { Petrobras } \\
\text { (Privado) }\end{array}$ & $\begin{array}{l}\text { Destaca os produtos que } \\
\text { atingem os graus máximos } \\
\text { de eficiência energética na } \\
\text { Etiqueta Nacional de } \\
\text { Conservação de Energia } \\
\text { (ENCE). }\end{array}$ & $\begin{array}{l}\text { Meio ambiente e } \\
\text { sociedade }\end{array}$ & Diversos & $\begin{array}{l}\text { Parte do } \\
\text { produto }\end{array}$ \\
\hline & $\begin{array}{l}\text { SUFRAMA e } \\
\text { FUCAPI } \\
\text { (Governo) }\end{array}$ & $\begin{array}{l}\text { Atesta a qualidade, } \\
\text { segurança e procedência da } \\
\text { matéria-prima dos } \\
\text { produtos da Amazônia } \\
\text { Brasileira. }\end{array}$ & $\begin{array}{l}\text { Meio ambiente e } \\
\text { sociedade }\end{array}$ & Diversos & $\begin{array}{l}\text { Parte do } \\
\text { produto }\end{array}$ \\
\hline
\end{tabular}

Fonte: informações obtidas nos sites das instituições e compiladas pela autora.

$\mathrm{Na}$ tabela 5 são listados alguns selos auto-declarados. Em alguns casos, houve divergência entre o que estava escrito no site e na embalagem. No caso da Ecobril, por exemplo, o relatório anual da empresa diz que as embalagens dos produtos são certificados pela Cerflor e IBD (Bombril, 2015), mas os selos destas instituições não estão expostos nas embalagens dos produtos. A empresa foi alvo de denúncia de uma ONG de direitos do consumidor devido a falhas na comunicação de seus apelos sustentáveis, mas não tem feito as mudanças sugeridas pela instituição (Proteste, 2016a). 
Tabela 5 - Selos sustentáveis (não exaustivo)

\begin{tabular}{|c|c|c|c|c|c|}
\hline Logo & Responsável & O que significa & Atuação & Categorias & Tipo de selo \\
\hline & Bombril & $\begin{array}{l}\text { O selo 4R - reduzir, recliclar, } \\
\text { reutilizar e respeitar a } \\
\text { biodiversidade - simboliza o } \\
\text { respeitar ao meio ambiente. }\end{array}$ & $\begin{array}{l}\text { Meio } \\
\text { ambiente }\end{array}$ & $\begin{array}{l}\text { Produtos de } \\
\text { limpeza, roupa } \\
\text { e casa - linha } \\
\text { Ecobril }\end{array}$ & $\begin{array}{l}\text { Produto com } \\
\text { um todo }\end{array}$ \\
\hline \multicolumn{2}{|r|}{ Coca-Cola } & $\begin{array}{l}\text { Embalagem de cana de açúcar, } \\
\text { substituindo parte do petróleo } \\
\text { utilizado como insumo, } \\
\text { reduzindo o uso de recursos } \\
\text { não-renováveis e emissões de } \\
\mathrm{CO}^{2} \text {. }\end{array}$ & $\begin{array}{l}\text { Meio } \\
\text { ambiente e } \\
\text { economia }\end{array}$ & $\begin{array}{l}\text { Bebidas - } \\
\text { embalagens } \\
\text { plásticas }\end{array}$ & $\begin{array}{l}\text { Produto } \\
\text { como um } \\
\text { todo } \\
\text { (insumo) }\end{array}$ \\
\hline $\begin{array}{l}\text { DuPont } \\
\text { Renewabl } \\
\text { Materials }\end{array}$ & DuPont & $\begin{array}{l}\text { Informa que o produto contém, } \\
\text { no mínimo, } 20 \% \text { de conteúdo } \\
\text { renovável em peso, ajudando a } \\
\text { reduzir a dependência do } \\
\text { petróleo e a produção líquida de } \\
\text { gases do efeito estufa. }\end{array}$ & $\begin{array}{l}\text { Meio } \\
\text { ambiente }\end{array}$ & Diversos & $\begin{array}{l}\text { Produto } \\
\text { como um } \\
\text { todo } \\
\text { (insumo) }\end{array}$ \\
\hline \multirow[t]{3}{*}{$\begin{array}{l}\text { Tecno } \\
\text { Ver }\end{array}$} & $\begin{array}{l}\text { Éh } \\
\text { Cosméticos } \\
\text { Brasil }\end{array}$ & $\begin{array}{l}\text { Fórmula que combina } \\
\text { ingredientes de extratos naturais } \\
\text { e inovadores. Produtos livres de } \\
\text { sal, sufato, parabenos, petrolatos } \\
\text { e corantes. }\end{array}$ & $\begin{array}{l}\text { Meio } \\
\text { ambiente }\end{array}$ & Cosméticos & $\begin{array}{l}\text { Parte do } \\
\text { produto }\end{array}$ \\
\hline & $\begin{array}{l}\text { Grupo Bimbo } \\
\text { Mexico }\end{array}$ & $\begin{array}{l}\text { Embalagem "oxidegradável" - } \\
\text { desintegram-se em até } 5 \text { anos } \\
\text { contra a de plásticos } \\
\text { convencionais que levam mais } \\
\text { de } 100 \text { anos. }\end{array}$ & $\begin{array}{l}\text { Meio } \\
\text { ambiente }\end{array}$ & $\begin{array}{l}\text { Alimentos - } \\
\text { embalagens } \\
\text { plásticas }\end{array}$ & $\begin{array}{l}\text { Produto } \\
\text { como um } \\
\text { todo }\end{array}$ \\
\hline & $\begin{array}{l}\text { Kimberly } \\
\text { Clark } \\
\text { EUA }\end{array}$ & $\begin{array}{l}\text { Embalagem compacta, } 100 \% \\
\text { de fibra virgem, celulose } \\
\text { certificada, plástico de fontes } \\
\text { renováveis e cadeia produtiva } \\
\text { usando processos para reduzir } \\
\text { os impactos no meio ambiente. }\end{array}$ & $\begin{array}{l}\text { Meio } \\
\text { ambiente e } \\
\text { economia }\end{array}$ & $\begin{array}{l}\text { Higiene - } \\
\text { Papel } \\
\text { higiênico } \\
\text { Neve }\end{array}$ & $\begin{array}{l}\text { Produto } \\
\text { como um } \\
\text { todo }\end{array}$ \\
\hline MÉ & $\begin{array}{l}\text { Natura } \\
\text { Cosméticos } \\
\text { Brasil }\end{array}$ & $\begin{array}{l}\text { Novas embalagens de refil que } \\
\text { fazem uso de menos plástico do } \\
\text { que as que estavam em linha } \\
\text { antes. }\end{array}$ & $\begin{array}{l}\text { Meio } \\
\text { ambiente }\end{array}$ & Cosméticos & Embalagem \\
\hline $\begin{array}{l}\text { EUS } \\
\text { PUS } \\
\text { VES }\end{array}$ & $\begin{array}{l}\text { Natura } \\
\text { Cosméticos } \\
\text { Brasil }\end{array}$ & $\begin{array}{l}\text { Embalagens produzidas a partir } \\
\text { da cana-de-açúcar, uma fonte de } \\
\text { energia vegetal e renovável, ao } \\
\text { contrário do plástico comum, } \\
\text { derivado do petróleo. }\end{array}$ & $\begin{array}{l}\text { Meio } \\
\text { ambiente e } \\
\text { economia }\end{array}$ & Cosméticos & Embalagem \\
\hline
\end{tabular}

Fonte: informações obtidas nos sites das instituições e compiladas pela autora.

Outros selos não foram encontrados nas páginas de busca na internet nem nas páginas dos fabricantes, mas encontrados no ponto de venda: 
- $100 \%$ fibras de área de reflorestamento - guardanapos Qualitá;

- $100 \%$ dos impressos em cartão fabricados no Brasil provem de florestas plantadas (ABRAF)

- Madeira 100\% reflorestada - produtos da Swedish Match Brasil (ex.: fósforo Fiat Lux).

Uma recente pesquisa levantou que a certificação mais reconhecida no Brasil é a do PROCEL, que foi citada por $75 \%$ dos respondentes. Em seguida, e já com níveis abaixo de 25\% de citações, estão as certificações CONPET, Orgânico Brasil, Energy Star, ISO 14001, FSC e I'm Green (Market Analysis, 2016). Faz-se importante ressaltar que o levantamento apresentado neste capítulo não buscou representar 100\% dos apelos sustentáveis existentes no Brasil atualmente, mas sim apresentar uma amostra dos selos e certificações mais relevantes por número de apresentação em produtos encontrados no varejo supermercadista, ou relevância nas páginas de busca pela internet. Não foram considerados os selos específicos sobre embalagens recicladas ou recicláveis, devido à grande diversidade de formas de apresentação destas informações.

Diversos autores defendem as certificações sustentáveis como as mais confiáveis, dado que envolvem um processo de auditoria e certificação (Gallastegui, 2002; Rubik et al., 2008; Thøgersen, 2000; Van Amstel et al., 2008). Neste contexto, diversos são os stakeholders envolvidos no processo de adoção de uma certificação, conforme será apresentado a seguir.

\subsection{Os stakeholders envolvidos com as certificações sustentáveis}

Para compreender o contexto da rotulagem sustentável no mundo, se faz importante avaliar o contexto de todos os stakeholders envolvidos no processo, a fim de levantar seu papel, suas contribuições e desafios. Considera-se um stakeholder, ou partes interessadas, todos os "indivíduos e organizações que são capazes de influenciar o resultado de um processo de tomada de decisão" (Morris, 1997, p.37). Vilchez, Darnall, e Correa (2016) 
estudaram quais stakeholders exercem influências sobre a adoção de práticas ambientais das empresas, e como as mesmas reagem a essas influências, concluindo que os impactos dessas relações vão além da influência somente na adoção ou não de práticas ambientais, atingindo também questões como o mapeamento do que será realizado, a abrangência das iniciativas e como/para quem elas serão divulgadas. Os autores sugerem ainda que as empresas podem ser mais propensas a ter comportamentos enganosos, como a maquiagem verde, quando percebem ter maior pressão de partes interessadas da sociedade (que tipicamente não têm acesso a informações sobre os riscos ambientais da empresa), e nenhuma pressão percebida por partes interessadas internas, reguladoras ou de cadeia de valor (Vilchez et al., 2016, p.10). Ou seja, há evidências de que as empresas reagem de forma diferente às pressões recebidas de diferentes stakeholders.

Para Horne (2009) e Thøgersen (2005), são três os principais grupos de stakeholders da rotulagem ambiental: consumidores, produtores e governos/outras agências. O primeiro autor considera que os recursos que financiam os selos e/ou /certificações e a origem do mesmo (seja na indústria, no governo ou em ONGs) afetam o nível de envolvimento dos stakeholders em seu processo. Ottman, Stafford, e Hartman (2006) incluem, além dos que já foram citados, ambientalistas destacados como influenciadores dessa cadeia. Já Morris (1997) divide os grupos de interesse em dois, sendo que os primários são os proprietários da marca da certificação, e os secundários incluem todos aqueles que fabricam produtos para os quais a certificação pode ser aplicada, bem como diversos outros atores, como organizações ambientais e de consumidores, que podem obter publicidade ou promover interesses particulares ao serem associados ao processo de certificação.

Na busca por levantar outros stakeholders envolvidos com a certificação de produtos, foi possível encontrar alguns mapeamentos que consideravam um número maior de atores na cadeia da rotulagem sustentável, como o de De Graaff (1995), conforme citado por Van Amstel et al. (2008), que mostra os grupos de interesse envolvidos no modelo de negócios da certificação, e as relações existentes entre eles, sejam regulatórias (linhas cheias) ou não (linhas pontilhadas) (vide Figura 3). Segundo o autor, é esse modelo que diferencia um selo auto-declarado (rotulagem tipo II) de uma certificação realizada por terceiro (rotulagem tipo I), ao separar a função do legislador (instituição padronizadora, que estabelece as regras e padrões para uma produção sustentável) da função do executor (certificador, que é responsável pela aplicação das normas e por assegurar o cumprimento dos produtores). No 
modelo também encontra-se um organismo de acreditação, que é responsável por garantir que todas as certificadoras são capazes de realizar as funções a que se propõem, assegurando sua independência, imparcialidade, confidencialidade e integridade, além do vendedor, que contrata os serviços das certificadoras para comprovar a implementação dos padrões estabelecidos pela instituição padronizadora, e os compradores, que ao final do processo fazem uso (ou não) da comunicação realizada pelo vendedor em relação ao seu diferencial sustentável. Vale ressaltar que uma instituição padronizadora pode coordenar diversas certificadoras para que façam uso e apliquem os padrões por ela estabelecidos.

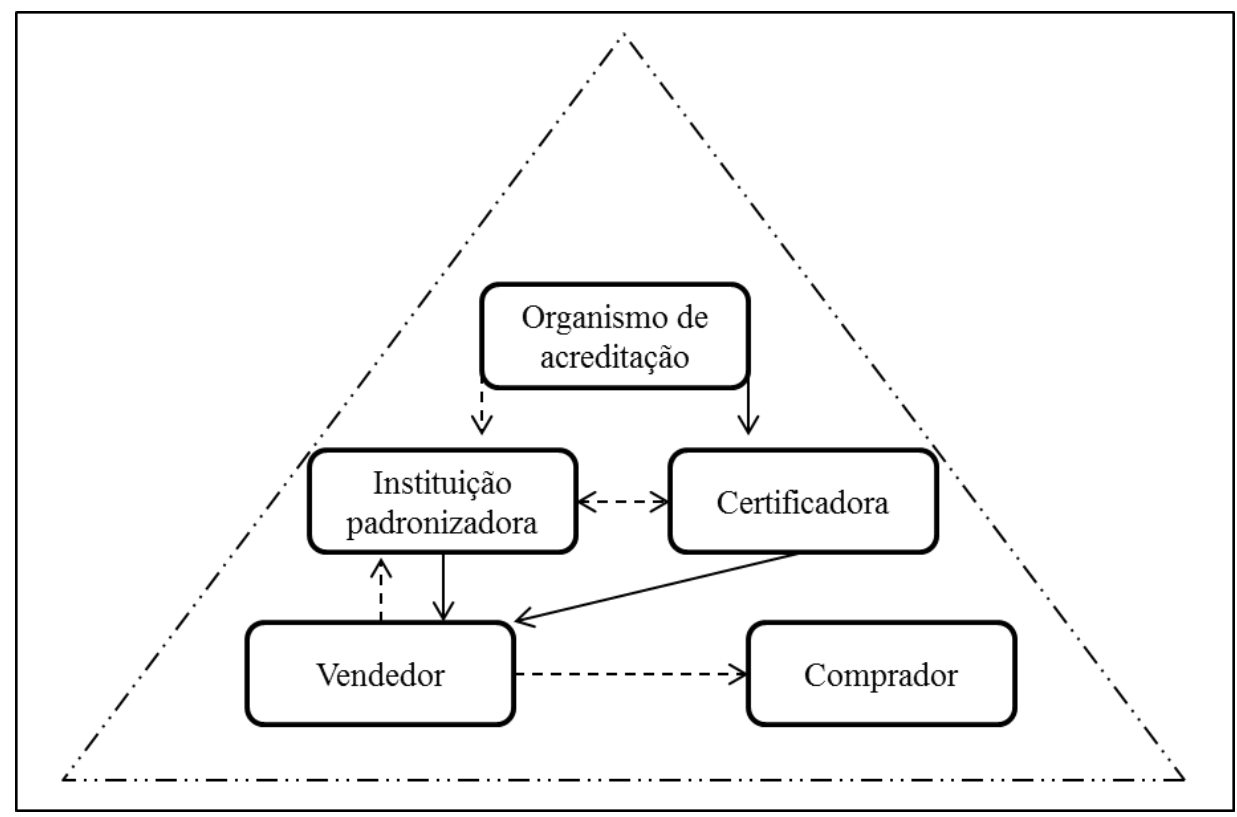

Figura 3 - Triângulo da certificação

Fonte: traduzido pela autora a partir de De Graaff (1995), conforme citado em Van Amstel et al. (2008)

Outro mapeamento encontrado, que pode ser visualizado na Figura 4, inclui outros stakeholders, e sugere as formas como as certificações são aplicadas pelas empresas para influenciar cada um deles: i) fornecedores e produtores (que talvez pudessem estar relacionados com o papel do "vendedor" do modelo apresentado anteriormente, na Figura 3): certificações são usadas para tomar decisões relacionadas às compras organizacionais e/ou para influenciar mudanças na cadeia produtiva; ii) clientes organizacionais: fazem uso das certificações para atender especificações de compras e requisição de informações, sejam do poder público, empresas ou outras instituições; iii) consumidor final: as certificações podem atender as expectativas dos consumidores em relação a alguma categoria de produtos e/ou suportam ou aprimoram a história da marca; iv) sociedade civil e reguladores: certificações 
são usadas para responder à pressão de determinados grupos e/ou para reportar as ações das empresas, além de atender aos requisitos legais de divulgação de informações sustentáveis; e v) colaboradores: certificações podem engajar e orientar colaboradores e/ou estabelecer metas a serem seguidas (SustainAbility, 2011, p.15).

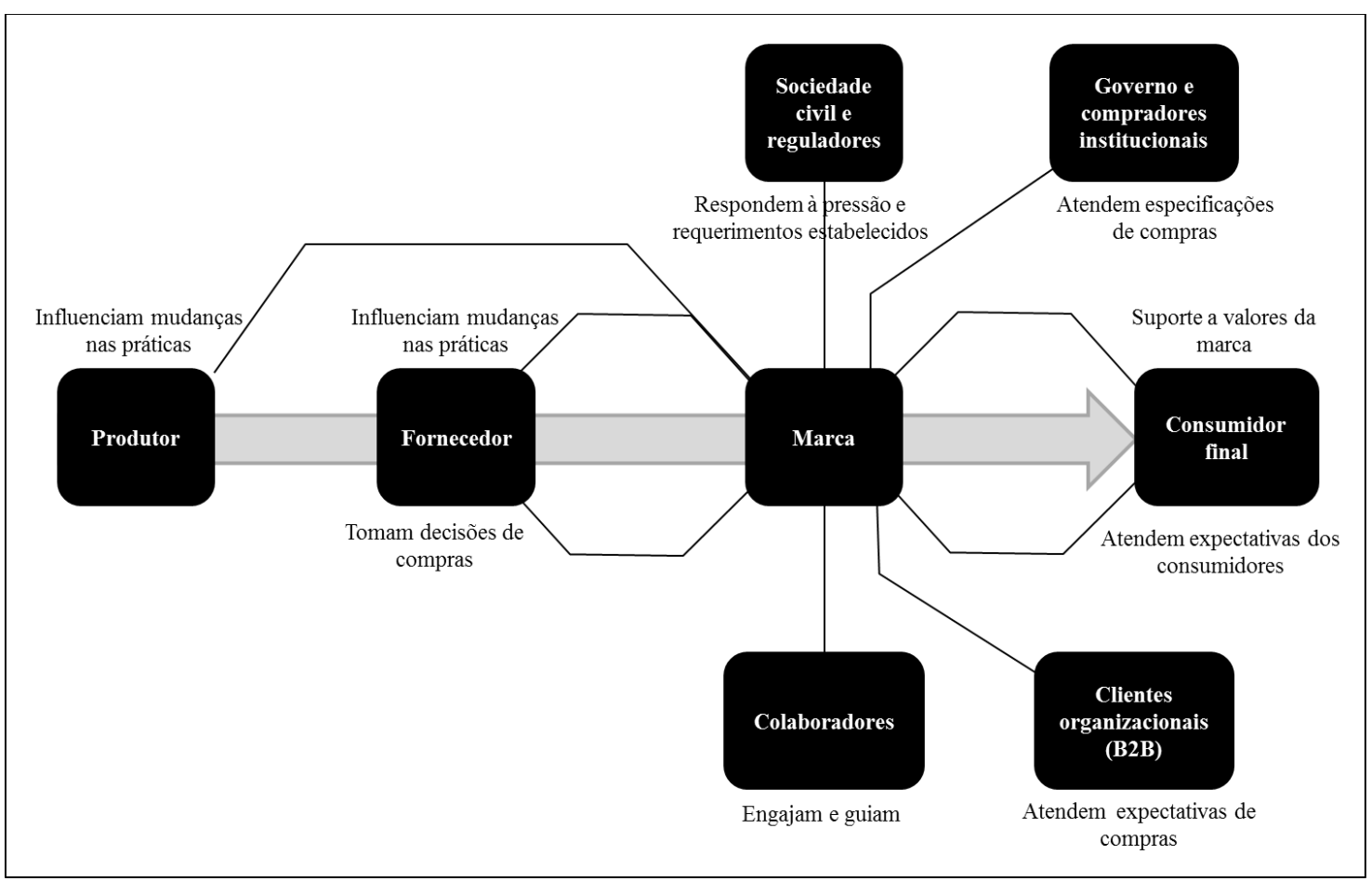

Figura 4 - Como as certificações são usadas pelos diversos stakeholders envolvidos Fonte: traduzido pela autora a partir de SustainAbility $(2011$, p.15)

Um terceiro mapeamento identificado é o de Ham (2007) e inclui novamente a padronizadora e a certificadora, além de incluir um novo stakeholder: os financiadores. No esquema apresentado pela Figura 5, que mostra como os atores envolvidos na certificação se relacionam entre si: i) consumidor: esquema das certificações é baseado no ideal de que os consumidores poderiam demandar produtos sustentáveis e, com isso, criar pressão de mercado nos produtores; ii) padronizadora: é a dona da marca da certificação sustentável e só permitem seu uso aos produtores que comprovarem adequação às regras por ela estabelecidas por meio de auditorias realizadas por certificadoras; iii) certificadora: tem a permissão concedida pela padronizadora para realizar a auditoria nos produtores, com objetivo de verificar se os mesmos atendem as regras por ela estabelecidas; iv) produtores: se aplicam à uma padronizadora para fazer uso da sua certificação, e deve se submeter a uma certificadora para demonstrar atendimento aos padrões estabelecidos, sendo que são necessários 
pagamentos tanto à padronizadora, para uso da certificação na embalagem e/ou outros materiais de comunicação, quanto à certificadora, para realização das auditorias; e v) financiadores: organizações como grupos ambientais ou outras partes interessadas que fazem doações para apoiar a atuação da padronizadora, que geralmente é uma ONG, e que não consegue obter recursos financeiros suficientes com as taxas recebidas pelas empresas em relação ao uso da sua marca.

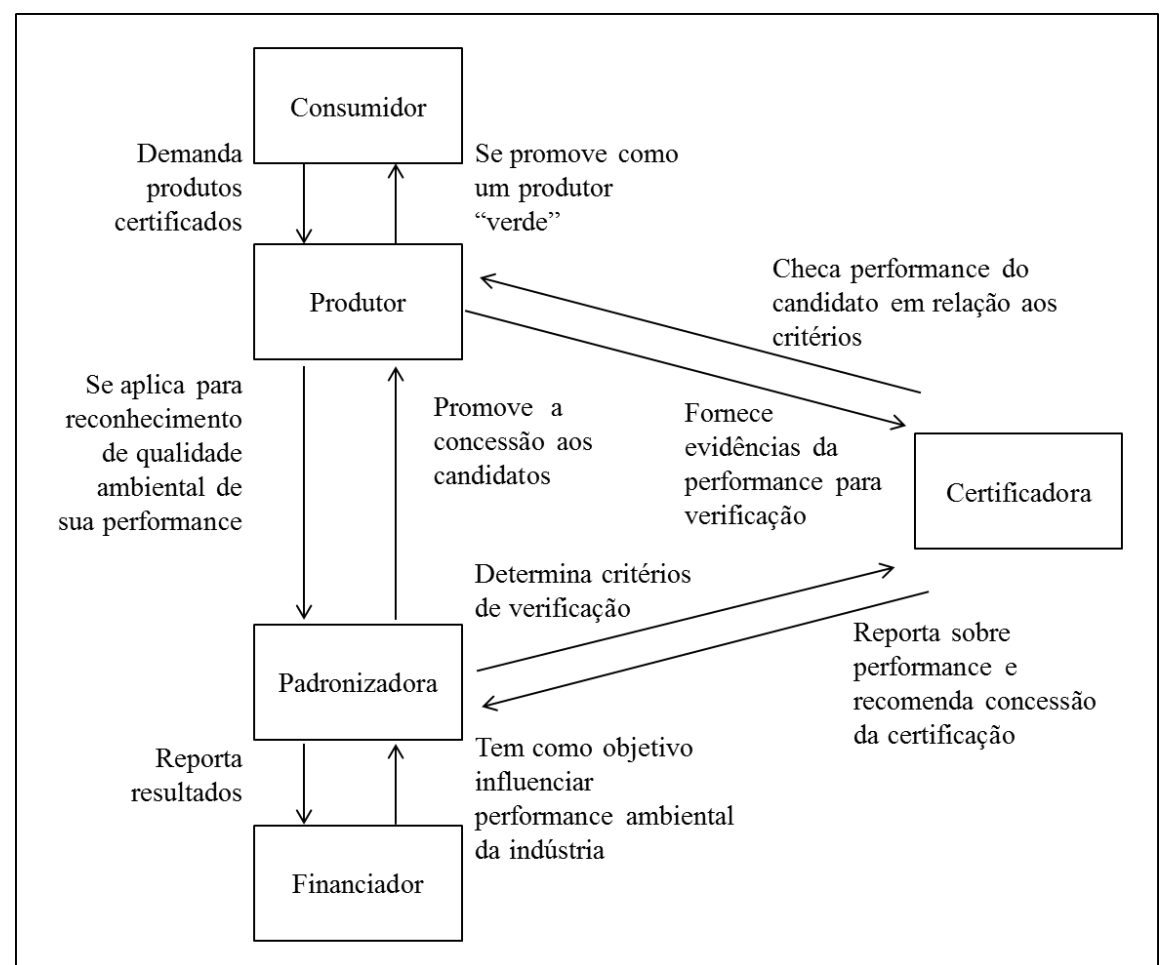

Figura 5 - Interação entre stakeholders envolvidos no processo de certificação Fonte: traduzido pela autora a partir de Ham (2007, p.16)

Foi possível identificar um último mapeamento, proposto pela UNEP (2015a), que também mapeia as relações entre os stakeholders, conforme apresentado na Figura 6: i) consumidores e organizações que os representam - estão no final da cadeia, recebendo as ISP. Além de receber, compreender e atuar com as informações recebidas, também se tornaram comunicadores das ISP, com o advento das mídias sociais. As organizações que representam consumidores muitas vezes participam de discussões promovidas por certificadoras e/ou fazem pesquisas e defendem os direitos dos consumidores em relação à ISP; ii) organizações não-governamentais (ONGs) e imprensa ${ }^{4}$ - as ONGs com apelos

\footnotetext{
${ }^{4}$ No caso da imprensa, seu papel não é detalhado no relatório da UNEP (2015a), mas optou-se por deixar registrado na listagem e na figura.
} 
sustentáveis geralmente buscam influenciar consumidores, produtores e governos a inserir a sustentabilidade em sua agenda, além de combater a maquiagem verde. Muitas vezes seu objetivo não é informar, mas sim fazer pressão para que produtos que causam impacto ambiental e/ou social negativo sejam alterados ou retirados do mercado; iii) organizações certificadoras e suas iniciativas - representam um grupo bem diverso, incluindo vários dos stakeholders apresentados nesta lista, que muitas vezes atuam em conjunto para definir padrões e projetos; seu objetivo é melhorar a forma como as empresas comunicam os seus impactos sustentáveis (oferecendo informação relevante e não utilizando informações confusas e/ou enganosas) por meio de verificação independente (rotulagem tipo I); iv) empresas (indústria/serviços e varejo) - elo de contato entre a oferta e a demanda de produtos, é um grupo que tem um papel central no processo e rotulagem sustentável. No caso da indústria, é quem decide se um produto terá algum apelo sustentável e, em caso afirmativo, como isso será comunicado, além de ser um forte influenciador de toda a cadeia logística envolvida na produção e entrega de seus produtos. No caso dos varejistas, pode-se atuar de maneira efetiva no fomento à evolução dos conceitos e práticas da sustentabilidade - seja priorizando cadeias de produção que considerem critérios socioambientais em seus negócios, seja estimulando o consumo consciente entre seus clientes; v) fornecedores industriais (B2B) - seu foco é comunicar as ISP às empresas, e não aos consumidores individuais, além de garantir o comprometimento com aspectos sustentáveis por parte de seus fornecedores e designers. Seu papel é fundamental no que tange à disponibilização de dados relacionados aos produtos fornecidos. Algumas associações de fornecedores (ex.: associação de indústrias químicas) também podem ter papel de destaque, ao se unir para desenvolver e incentivar a mensuração de impacto socioambiental; vi) pesquisadores e consultores - apoiam no desenvolvimento de ferramentas, abordagens, métodos e bancos de dados. Podem também fazer parcerias com empresas para apoiar na definição de sua posição em relação à sustentabilidade, além de identificar oportunidades de melhoria; vii) organizações governamentais - muitos governos apoiam pelo menos uma iniciativa de certificação sustentável, buscando facilitar/apoiar a produção e comunicação de informação crível e objetiva. Além disso, pode criar políticas e incentivos para desenvolver a sustentabilidade em determinados setores, como de produção/consumo de energia, ou de transporte; legislar sobre barreiras comerciais e criar demanda por produtos mais sustentáveis por meio do processo de compras públicas. 


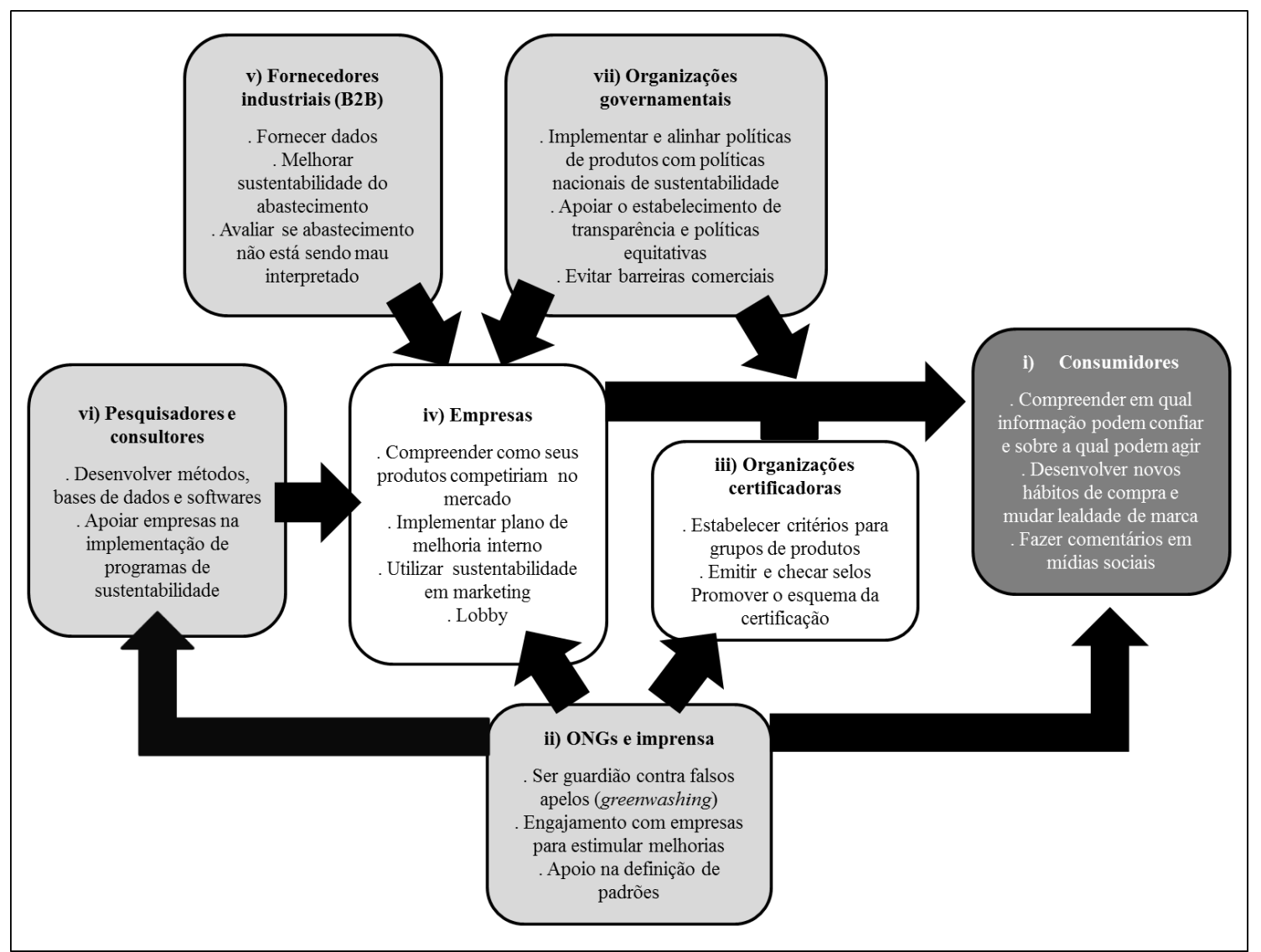

Figura 6 - Mapeamento simplificado de stakeholders e seus principais papéis

Fonte: traduzido pela autora a partir de UNEP, 2015a, p.15

Segundo a UNEP (2015a), cada um desses stakeholders têm interesses próprios e, por vezes sobrepostos. Eles podem ter diferentes influências com diferentes níveis de intensidade sobre o processo de criação e comunicação de selos e certificações e, portanto, não há uma única maneira de identifica-los e categorizá-los. Para organizar as informações referentes aos mapeamentos apresentados, optou-se por fazer uma nova proposta consolidada, que servirá como base para compreender as relações existentes entre os stakeholders no que tange as barreiras para adesão às certificações sustentáveis.

O primeiro passo para elaborar este novo mapeamento foi o de estruturar os stakeholders da cadeia produtiva de forma a mostrar o movimento dos insumos até virarem produto final e chegarem às mãos do consumidor, num modelo tradicional de negócios ${ }^{5}:$ o fornecedor compra as matérias-primas e as converte em insumos (ex.: embalagens plásticas, caixas de papelão, fragrâncias etc), que são vendidos às empresas de bens de consumo ou a governos. Estas

\footnotetext{
${ }^{5}$ Não é objetivo do presente trabalho discutir novas formas de acesso ao consumidor nem novos arranjos de negócios (venda por meio de websites etc).
} 
incluem os insumos em seu processo fabril para produzir bens de consumo, como sabonetes, sapatos e alimentos, que, posteriormente, serão conduzidos a uma cadeia de distribuição, que pode envolver diversos tipos de distribuidores e varejistas, até finalmente chegar ao consumidor. Os produtos de empresas de bens de consumo e de varejistas também podem ser adquiridos pelos governos, em seu papel de comprador para manter a estrutura pública em atividade, seja ela qual for. Ao grupo formado por todos os stakeholders mencionados neste parágrafo (consumidores finais, empresas e o governo, em seu papel de comprador) deu-se a denominação de "decisor", dado que eles têm atuação direta na decisão pela adoção de produtos certificados em suas escolhas de consumo.

Um segundo grupo, denominado de "executor", conta com as organizações padronizadoras, que tem o papel de estabelecer os critérios e métodos para viabilizar as certificações, e as organizações certificadoras, que são as responsáveis por realizar os processos de auditoria que culminam com a concessão dos certificados. Já o terceiro grupo inclui aqueles que tem um papel de "apoiador" do processo (ONGs e imprensa, pesquisadores/consultores e governo, em seu papel de legislador). Estes stakeholders influenciam o ambiente institucional de determinada região (cidade/estado/país), por meio da divulgação de notícias, a realização de pesquisas e/ou o estabelecimento de leis. A nova proposta de mapeamento pode ser vista na Figura 7.

Note-se que no modelo proposto todos os stakeholders estão, de alguma forma, interligados, influenciando e sendo influenciados uns pelos outros, pois considerou-se a afirmativa de Thøgersen (2005) para quem todos os grupos de interesse se influenciam mutuamente. Vale ressaltar que o autor listou apenas governos, empresas e cidadãos como os principais atores do processo de consumo sustentável, mas ao estudar os diversos mapeamentos já apresentados, pode-se considerar que esta premissa é válida para os demais também. 


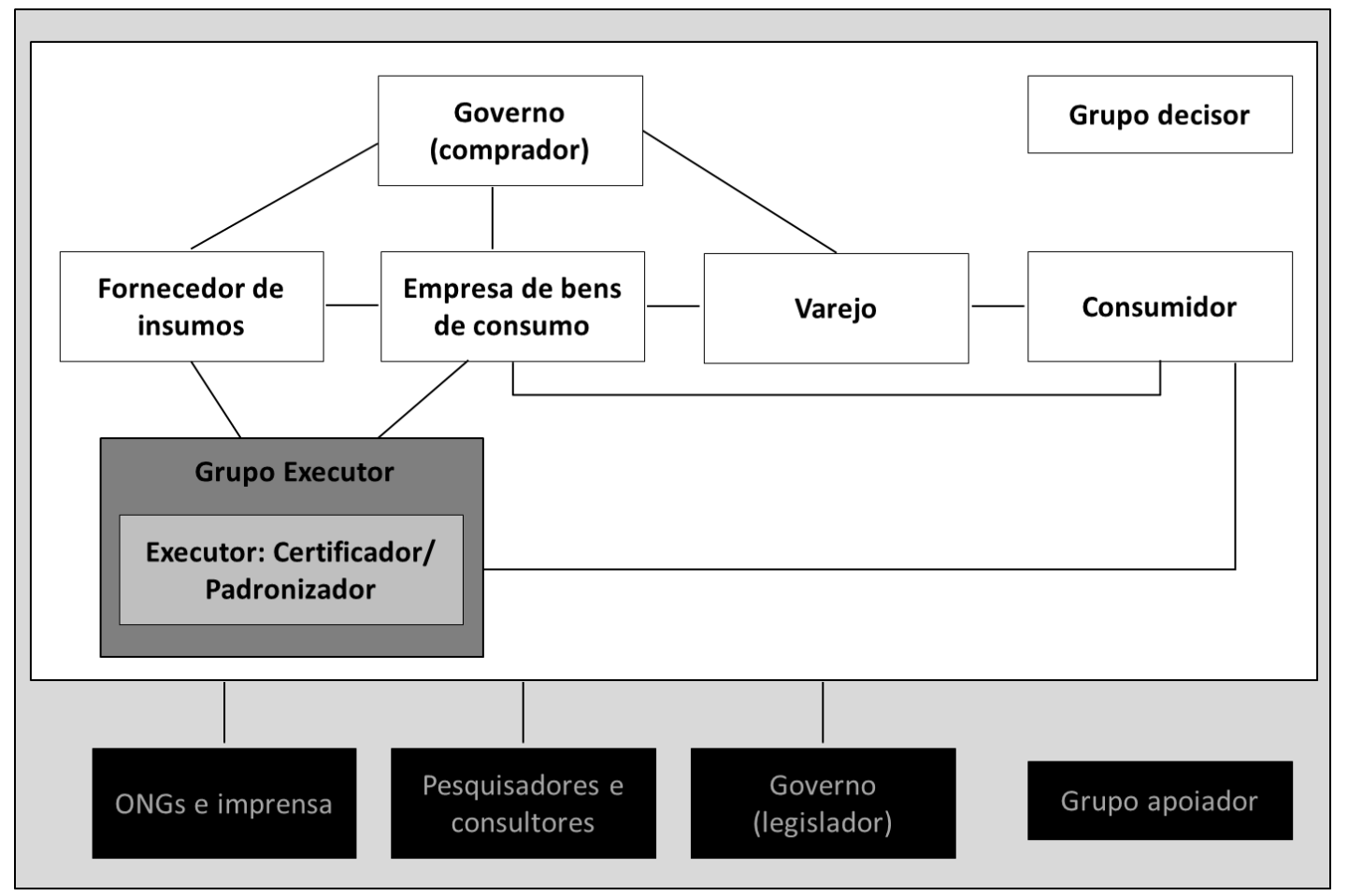

Figura 7 - Divisão de stakeholders em grupos de acordo com seu papel no contexto da certificação Fonte: elaborado pela autora com base nas referências bibliográficas.

Segundo a definição de certificação ambiental proposta pela Agência de Proteção Ambiental dos Estados Unidos, pode-se considerar que os esquemas de certificações sustentáveis servem a dois grandes propósitos: no mercado entre empresas (B2B), provêm informações para os compradores industriais acerca da saúde, segurança e impacto ambiental dos produtos, estimulando-os a comprar estes produtos a fim de minimizar impactos no meio ambiente; já na outra ponta da cadeia produtiva, nos negócios envolvendo o consumidor (B2C), eles são também uma forma de apoiar os consumidores no momento da compra, informando sobre atributos ambientais dos produtos e serviços que consideram adquirir, com o objetivo de mudar hábitos de consumo, fazendo com que as pessoas passassem a escolher produtos que causem menor impacto no meio ambiente (US Environmental Protection Agency - EPA, 1998). Estudos relacionados à estas duas relações serão apresentados a seguir.

\subsubsection{Estudos sobre certificações nas relações B2C e B2B}

O campo de estudos acerca do comportamento dos consumidores em relação ao selos e certificações sustentáveis conta com diversas publicações e linhas de pesquisa diferentes. Para 
compreender como os consumidores tem se relacionado com o tema, autores já buscaram avaliar a percepção dos mesmos sobre certificações específicas, como Fairtrade (Coelho, 2015; De Pelsmacker \& Janssens, 2007; Loureiro \& Lotade, 2005), pegadas de carbono (Kimura et al., 2010; Upham, Dendler, \& Bleda, 2011), certificações relacionadas à sustentabilidade na pesca (D’Souza, 2000; Thøgersen et al., 2010), plástico verde - selo 'I'm Green" (Kruter, Barcellos, \& Silva, 2012) e orgânicos (Kohlrausch et al., 2004; Rodrigues, Dalmarco, Aoqui, \& Marinho, 2016; Wander, Lacerda, Freitas, Didonet, \& Didonet, 2007), dentre diversos outros. Estes estudos em geral também avaliam os perfis de consumidores que tem mais afinidade com a causa da rotulagem sustentável e, consequentemente, apresentam uma maior tendência de fazer suas escolhas com base na presença da certificação, estando, inclusive, dispostos a pagar mais por isso.

Em relação ao conhecimento e compreensão dos apelos sustentáveis, nota-se que poucos consumidores conseguem identifica-los e/ou sabem dizer o que eles significam (Grunert et al., 2014; Hamza \& Dalmarco, 2012; Morris, Hastak, \& Mazis, 1995; Nilsson et al., 2004). Morris et al. (1995), por exemplo, pesquisaram a compreensão sobre termos "reciclado" e "reciclável", concluindo que apenas $5 \%$ da amostra conseguia definir os termos corretamente. Para Hamza e Dalmarco (2012), faltam ao consumidor conhecimentos básicos sobre os apelos sustentáveis: o que são, para que servem, quais existem, o que significam. Um dos grandes desafios da rotulagem sustentável, portanto, é conseguir transmitir a informação de uma forma simples e fácil de ser compreendida (D’Souza, Taghian, \& Lamb, 2006; Grunert et al., 2014), o que é corroborado por Leire e Thidell (2005), para quem o formato no qual a ISP é apresentada afeta a aceitação do consumidor. Os autores defendem que os formatos mais simples, auto-explicativos, são os mais desejados pelos consumidores, e também suficientes para a tomada de decisão. Mas Fabíola Zerbini, em entrevista para Andreoni (2013), ressalta que essa falta de reconhecimento dos selos e certificações sustentáveis se deve ao pouco tempo de entrada desse tipo de comunicação na vida das pessoas, que aconteceu entre 15 e 20 anos atrás.

Já no campo de estudos acerca do uso das certificações sustentáveis nas práticas de negócios industriais, foi possível encontrar pesquisas que mencionam as motivações para adoção e/ou uso das mesmas pelas empresas (Overdevest \& Rickenbach, 2006; Pedersen \& Neergaard, 2006), o quanto ações de marketing poderiam impulsionar seu impacto e abrangência (Pickett-Baker \& Ozaki, 2008; Rex \& Baumann, 2007), questões relacionadas à 
imprevisibilidade da demanda por produtos certificados e seu impacto não processo decisório da adoção das certificações (D’Souza, 2004).

O estudo de Overdevest \& Rickenbach (2006) elencou as três principais motivações das empresas desenvolverem mecanismos de política florestal, relacionadas a certificações de manejo, como a FSC e o Cerflor, a saber: i) orientação ao mercado - que tem expectativa de obter benefícios diretos de mercado, como a possibilidade de cobrar preços maiores ou atender a demanda de clientes; ii) orientação para sinalização - que busca sinalizar stakeholders externos (ativistas, varejistas e governo) que a empresa está atendendo aos mais altos padrões em suas práticas florestais e produtivas, endereçando possíveis preocupações destes grupos em relação à incertezas políticas e ecológicas; e iii) orientação para aprendizagem - que considera a certificação como uma forma de aprimorar as práticas florestais e produtivas, por meio do contato com novos conceitos e práticas ecológicas a que as empresas são expostas durante o processo de certificação e também por meio da revisão de todo o processo da empresa para atender aos padrões solicitados.

O tema das certificações também aparece em estudos sobre a forma como as empresas lidam com questões sustentáveis de uma forma geral, como no caso de Vilchez et al. (2016), que desenvolveram uma proposta de classificação para as empresas em relação a quanto elas dão visibilidade às suas ações ambientais (muita ou pouca visibilidade), e o quão ampla é sua atuação em relação às questões relacionadas ao meio ambiente (poucas questões ou muitas). Os autores propõem quatro tipos de estratégias possíveis, e posteriormente descrevem as práticas comuns a cada uma delas, incluindo quais eram mais propensas a fazer uso de selos auto-declarados ou certificações auditadas por terceira parte.

Estudos que considerem o ponto de vista de diversos stakeholders da mesma cadeia de valor são esparsos. Bhaskaran et al. (2006), por exemplo, fizeram entrevista com gestores de empresas da cadeia de valor de produtos alimentícios em uma cidade da Austrália e concluíram que a demanda por produtos alimentícios produzidos de forma ambientalmente correta ainda não era alta devido a um problema de demanda - os consumidores não enxergavam os benefícios que os mesmos ofereciam, além de não confiarem nos apelos utilizados pelas empresas e acharem que as terminologias utilizadas eram muito confusas (ex.: orgânico, verde, ambientalmente correto etc). Já Ham (2007) também estudou os diversos stakeholders envolvidos na cadeia da certificação FSC da África do Sul, a fim de mapear o 
mercado de produtos com esta certificação, tendo levantado, dentre outras questões, as dificuldades encontradas pelas empresas em adotá-la.

Porém, a cadeia de valor envolvida no suprimento de matérias primas para serem transformadas em produtos pode ser um importante impulsionador do uso de certificações por parte das empresas, dados que os participantes desta cadeia têm uma relação com alto poder de influência mútua (Hakansson \& Ford, 2002; Orsiolli \& Nobre, 2016). Karin Kreider, Diretora Executiva da ISEAL's ${ }^{6}$ Alliance, ao ser indagada num webinar sobre para qual relação comercial (B2B ou B2C) as certificações sustentáveis seriam mais relevantes, respondeu que seria para o $\mathrm{B} 2 \mathrm{~B}$, devido a questões de posicionamento da empresa ou reconhecimento de responsabilidade por parte dos investidores do setor financeiro (Iseal Alliance, 2016). Neste contexto, as certificações poderiam ser consideradas um tema a ser aprofundado na linha de pesquisa da área de operações de empresas referente à gestão de cadeias de suprimentos sustentáveis, conforme será apresentado no próximo tópico.

\subsubsection{Gestão da cadeia de suprimentos sustentável (GCSS)}

A gestão da cadeia de suprimentos sustentável (GCSS) pode ser definida como "a gestão fluxos de materiais, informações e recursos, assim como a cooperação entre empresas ao longo da cadeia de fornecimento, tendo simultaneamente em conta as metas de todas as três dimensões do desenvolvimento sustentável (económicas, ambientais e sociais), que são derivadas dos requisitos dos clientes e das partes interessadas" (Seuring e Müller, 2008, p.1700).

O trabalho de Seuring e Müller (2008) é muito citado em estudos sobre o tema, pois os autores fizeram uma extensa revisão bibliográfica, e propuseram um modelo conceitual que resume o que foi encontrado em três grandes partes: i) as motivações para adoção da GCSS, que são muito influenciadas por pressões e incentivos de stakeholders como o governo e os consumidores; e duas estratégias distintas que respondem à essas motivações: ii) gestão de cadeia de suprimentos com foco em minimizar riscos e aumentar a performance ambiental; e iii) gestão de cadeia de suprimentos com foco do desenvolvimento de produtos sustentáveis.

\footnotetext{
${ }^{6}$ A ISEAL Alliance é uma associação global de esquemas de certificação social e ambiental.
} 
Eles ressaltam que quando uma empresa é pressionada a adotar padrões mais sustentáveis de produção, ela geralmente repassa esta pressão para seus fornecedores e que, ao se tratar de questões sustentáveis, as empresas devem considerar sua cadeia de suprimentos de forma mais abrangente do que é necessário quando considera-se apenas questões econômicas.

Outros trabalhos encontrados avaliam a GCSS em determinados países e setores, como nas empresas Chinesas de uma forma geral (Zhu, Sarkis, \& Geng, 2005), na indústria automotiva da Alemanha (Thun \& Müller, 2010), ou na indústria da construção nos Emirados Árabes Unidos (Balasubramanian, 2012). Também há trabalhos específicos em relação a pequenas empresas (Mathiyazhagan, Govindan, NoorulHaq, \& Geng, 2013; Perron, 2005). Note-se que todos os trabalhos mencionados tratam de questões ambientais da cadeia de suprimentos, sendo que a predominância destas nos estudos sobre GCSS é destacada por Seuring e Müller (2008), que ressaltam ser mais difícil encontrar pesquisas que contemplem questões sociais ou ainda a integração entre as três dimensões da sustentabilidade (econômica, social e ambiental).

Neste contexto, o estudo de Marshall, McCarthy, McGrath, e Claudy (2015) buscou ajudar a preencher esta lacuna, ao analisar o que impulsiona a adoção de diferentes práticas sociais na GCSS. Segundo os autores, a maioria das publicações levantadas em sua revisão bibliográfica mostra que as práticas da cadeia de suprimentos sustentável com foco na questão social se concentram na saúde e segurança dos trabalhadores ao longo da cadeia de fornecimento, em códigos de conduta para garantir direitos humanos e condições de trabalho, e em sistemas de responsabilidade social, como a SA8000. São citados autores como Pfeffer (2010) e Pullman et al. (2009) para descrever que, ao focar as pessoas dentro das empresas, e também em toda a cadeia de valor, as organizações podem reduzir o absenteísmo, custos relacionados à saúde dos trabalhadores, a treinamentos e reposição de vagas (Marshall et al., 2015, p.21).

Note-se que a questão das certificações nem sempre é citada nestes trabalhos e, quando o são, estão geralmente relacionadas à ISO 14001 (gestão ambiental) e/ou OHSAS 18001 (saúde e segurança ocupacional) e/ou SA8000 (responsabilidade social) (Chan, He, \& Wang, 2012; Sarkis, 2003; Seuring \& Müller, 2008; Silva, Shibao, \& Santos, 2016; Srivastava, 2007; Zhu et al., 2005). Seuring e Müller (2008), por exemplo, cita que muitas empresas solicitam que seus fornecedores atuem de acordo com certos padrões ambientais e sociais estabelecidos, 
o que geralmente pode ser feito por meio das certificações. Menções a outras certificações voluntárias de mercado (como FSC, Fairtrade ou Rainforest Alliance) ainda são esparsas nos estudos sobre GCSS.

Como exemplo, pode-se citar a pesquisa de Bartley (2003), que busca explicações sobre o surgimento e expansão dos sistemas privados de certificação, tomando como unidade de análise os segmentos relacionados ao manejo florestal e à indústria da moda. Ao comparar as duas indústrias, o autor menciona que uma das grandes diferenças entre elas está relacionada à estrutura de produção, sendo que a produção de roupas tende a ocorrer por meio de cadeias de fornecimento descentralizadas com vários níveis de contratação, e a produção de produtos florestais é mais provável que aconteça entre um pequeno número de grandes empresas verticalmente integradas, que possuem a terra, fazem a colheita e processam a madeira, operam as plantas de celulose e papel e, às vezes, até mesmo produzem os produtos químicos para esses processos (p.43).

Por sua vez, em seu estudo sobre o papel que a certificação de emissões de carbono podem ter na economia, Cohen e Vandenbergh (2012) citam a atuação dos participantes da cadeia de fornecimento de produtos em diversos momentos, mostrando como os mesmos podem participar do fortalecimento deste tipo de certificação. Já Ham (2007) buscou compreender como funcionava o mercado de produtos relacionados à certificação de manejo florestal FSC na África do Sul, analisando diversos atores da cadeia, sendo que um dos focos destacados foi a comparação das respostas dadas por os produtores de madeira e os seus processadores acerca de questões como a opinião a respeito do FSC e seus impactos na indústria florestal, as vantagens e desvantagens de adotar a certificação, assim como as barreiras que dificultam o processo, dentre outras.

Outros estudos da GCSS tiveram como objeto de pesquisa especificamente as barreiras à adoção de práticas sustentáveis na cadeia de suprimentos das empresas, e podem servir de referência para iniciar um processo de sistematização das barreiras às certificações sustentáveis, dado que ambos os temas são inter-relacionados. Estas referências analisadas tratam geralmente das barreiras à adoção da GCSS por parte das empresas de algum setor e país específico, como o de mineração na Índia (Muduli, Govindan, Barve, \& Geng, 2013), automotivo no Brasil (Silva et al., 2016), construção nos Emirados Árabes Unidos (Balasubramanian, 2012) ou pequenas empresas no Canadá (Perron, 2005). 
Todos os estudos citados propõem alguma forma de categorização das barreiras encontradas, conforme citado por Silva et al. (2016): i) Govindan et al. (2014): terceirização, tecnologia, conhecimento, financeiro e envolvimento/apoio; ii) Mathiyazhagan et al. (2013), financeira, gestão, regulamentação, clientes e tecnologia; iii) Muduli et al. (2013), regulamentação, recursos, stakeholders e informação; e iv) Balasubramanian (2012) com a distribuição das barreiras em 12 categorias diferentes.

O estudo de Walker e Jones (2012), do Reino Unido, não teve foco em nenhuma indústria especifica do país, e as categorias foram construídas por meio de revisão bibliográfica que teve como objetivo central avaliar o ponto de vista de stakeholders do processo. Os autores dividiram as barreiras entre externas e internas e, posteriormente, as subdividiu: as barreiras externas estariam ligadas à pressão exercida por stakeholders de mercado, e as barreiras internas estariam relacionadas a questões intrínsecas à organização, conforme pode ser visualizado na Tabela 6:

Tabela 6 - Classificação das barreiras à GCSS

(continua)

\begin{tabular}{|c|c|c|c|}
\hline \multicolumn{2}{|r|}{ Barreiras Externas } & \multicolumn{2}{|r|}{ Barreiras Internas } \\
\hline Categoria & Subcategoria & Categoria & Subcategoria \\
\hline Governo & . Regulamentação; & Pessoas & $\begin{array}{l}\text { Falta de comprometimento dos } \\
\text { gestores; }\end{array}$ \\
\hline Competidores & . Pressão competitiva; & $\begin{array}{l}\text { Questões } \\
\text { estratégicas }\end{array}$ & $\begin{array}{l}\text { Limitação de recursos (custo e } \\
\text { outros); } \\
\text {. Mensuração de performance } \\
\text { (métodos contábeis tradicionais); } \\
\text {. Tamanho das empresas (empresas } \\
\text { menores); }\end{array}$ \\
\hline Consumidores & $\begin{array}{l}\text { Demanda por preços mais } \\
\text { baixos; } \\
\text {. Compreensão sobre desejos e } \\
\text { comportamento; }\end{array}$ & $\begin{array}{l}\text { Questões } \\
\text { funcionais }\end{array}$ & $\begin{array}{l}\text { Função da área de compras (falta } \\
\text { de treinamento; falta de } \\
\text { compreensão sobre como } \\
\text { incorporar as questões nas compras; } \\
\text { outras prioridades; falta de } \\
\text { estruturas e processos corporativos; } \\
\text { processo de GCSS ainda pouco } \\
\text { robusto); }\end{array}$ \\
\hline
\end{tabular}


(conclusão)

\begin{tabular}{|c|c|c|c|}
\hline \multicolumn{2}{|r|}{ Barreiras Externas } & \multicolumn{2}{|r|}{ Barreiras Internas } \\
\hline Fornecedores & $\begin{array}{l}\text { Baixo envolvimento; } \\
\text {. Muita pressão em um único } \\
\text { fornecedor por parte dos } \\
\text { consumidores; } \\
\text { Volumes muito altos } \\
\text { significam que a demanda pode } \\
\text { ultrapassar oferta; }\end{array}$ & $\begin{array}{l}\text { Risco de } \\
\text { reputação }\end{array}$ & $\begin{array}{l}\text { Reputação de marca forte significa } \\
\text { gestão a mais de cadeia de } \\
\text { suprimentos sem necessariamente } \\
\text { criar mais demanda por seus } \\
\text { produtos; }\end{array}$ \\
\hline Mídia & $\begin{array}{l}\text { Maquiagem verde; } \\
\text {. Volume de informações sobre } \\
\text { responsabilidade social } \\
\text { corporativa; }\end{array}$ & $\begin{array}{l}\text { Gestão de } \\
\text { performance }\end{array}$ & $\begin{array}{l}\text { Objetivos contrários de } \\
\text { performance; } \\
\text {. Auditorias muito extensas; }\end{array}$ \\
\hline Setorial & $\begin{array}{l}\text { Indústrias menos } \\
\text { regulamentadas; } \\
\text {. Códigos de conduta } \\
\text { padronizados limitam inovação; }\end{array}$ & $\begin{array}{l}\text { Tamanho da } \\
\text { organização }\end{array}$ & . Operações em larga escala; \\
\hline ONGs & . Exigências diversas; & $\begin{array}{l}\text { Integração } \\
\text { interna }\end{array}$ & Comunicação \\
\hline Global & $\begin{array}{l}\text { Aspectos globais (barreiras de } \\
\text { idioma e culturais; certificações } \\
\text { diferentes em diferentes países; } \\
\text { certificações internacionais } \\
\text { como uma barreira à } \\
\text { competitividade); } \\
\text {. Necessidade de se definir se } \\
\text { fornecimento deve ser local ou } \\
\text { global. }\end{array}$ & & \\
\hline
\end{tabular}

Fonte: traduzido e organizado pela autora a partir de Walker e Jones (2012).

Neste contexto, considerando que: i) o campo de pesquisas sobre certificações com consumidores já conta com diversas publicações e linhas de pesquisa bem desenvolvidas; ii) que as pesquisas sobre certificações sustentáveis na GCSS ainda são esparsas, ainda mais quando se consideram as certificações fora do sistema ISO, OHSAS 18001 e SA8000; e iii) que estas certificações sustentáveis fora do sistema anteriormente mencionado, como FSC, Fairtrade ou Rainforest Alliance, seriam mais relevantes para o mercado B2B do que B2C, a presente pesquisa terá como foco as relações entre organizações, com objetivo de compreender como as barreiras às certificações influenciam as relações entre as empresas de bens de consumo e os principais stakeholders envolvidos no processo de adoção às mesmas: aqueles que fornecem os insumos certificados e as certificadoras/padronizadoras, que definem os padrões a serem seguidos (vide Figura 8). No tópico a seguir serão apresentadas as barreiras já encontradas na revisão bibliográfica. 


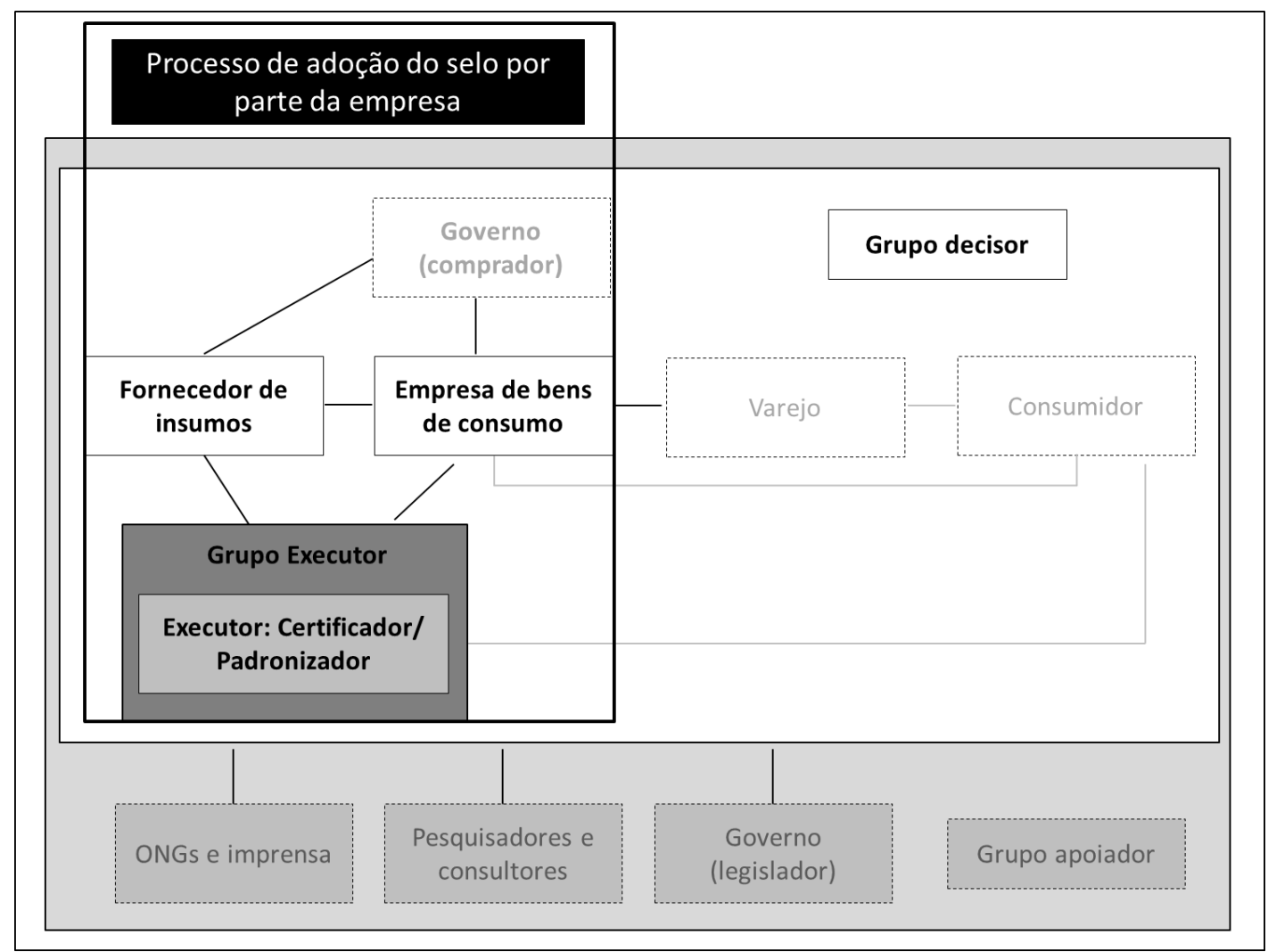

Figura 8 - Principais stakeholders envolvidos na adoção da certificação por parte das empresas de bens de consumo

Fonte: elaborado pela autora

\subsection{As barreiras enfrentadas pelas empresas na adoção de certificações sustentáveis}

Conforme já mencionado, nenhum estudo que trate especificamente das barreiras para adoção das certificações sustentáveis foi encontrado até o momento. As barreiras geralmente são citadas em artigos diversos sobre certificação envolvendo diversos públicos, e não somente as empresas e seus fornecedores, e devido a isso se torna mais complicado encontralas e sistematiza-las. A leitura atenta dos artigos deve buscar temas relacionados à sua implementação e/ou opinião por parte das empresas que já a utilizam, dado que muitas vezes o termo "barreiras" não é utilizado, mas sim "problemas", "dificuldades", "desvantagens", "riscos". A seguir são apresentadas todas as barreiras encontradas nos estudos consultados durante a revisão bibliográfica.

Uma questão crucial para todo desenvolvimento de produtos está relacionada à estimativa de demanda pelo mesmo, a fim de que seja possível calcular se o investimento trará o retorno 
esperado. Além disso, é por meio desta estimativa que estabelece-se a compras de insumos e os volumes de produção, estratégias de distribuição, dentre diversas outras decisões relevantes a serem tomadas. Diversos autores registraram a dificuldade de se estimar a demanda por produtos certificados. Uma das possíveis justificativas está relacionada à lacuna que existe entre o discurso ambientalmente correto por parte dos consumidores e sua prática real no momento da compra (Cornelissen et al., 2007; Hartikainen et al., 2014; Pedersen \& Neergaard, 2006). Um outro ponto foi levantado por D’Souza (2004), que fez uma proposta de segmentação dos consumidores em relação a duas variáveis: i) o uso de certificações para identificar produtos melhores do ponto de vista ambiental; e ii) os riscos e benefícios associados ao uso destas certificações. Segundo a autora, a maioria das pesquisas sugere que esses rótulos são exigidos e susceptíveis de serem notados, porém ainda há dúvidas se a questão dos produtos apresentarem um preço maior influenciaria o aumento da demanda. Esta afirmação foi considerada uma barreira para a implementação das certificações no que tange a imprevisibilidade da demanda de produtos certificados.

A profusão do número de selos e certificações foi tratada no relatório da Iseal Alliance (2010), que mencionou que a maior insatisfação de empresários em relação ao tema se refere ao crescente número de certificações existentes: "muita proliferação e pouca penetração (p.15), foi uma das citações registradas pelos entrevistadores. Segundo a instituição, isto gera sobreposição de padrões e a dificuldade para diferenciá-los, além de haver falta de informações sobre cada um em específico. Já em relação aos consumidores, o tema foi tratado por Brécard (2014), que mostrou que: i) a empresa que fornece um produto com certificação que ateste uma alta qualidade ambiental é enfraquecida pela confusão do consumidor; ii) a empresa que vende o produto sem certificação sofre com as normas, que são muito restritas; e iii) a empresa que fornece um produto com certificação, mas que atesta uma menor qualidade ambiental, acaba por ganhar uma vantagem competitiva. Esta "penalização" para empresas com maior comprometimento também é citada por Pedersen e Neergaard (2006) como um dos efeitos da "maquiagem verde" que, em seu pior cenário, pode prejudicar a credibilidade da prática de rotulagem sustentável como um todo, impactando inclusive as empresas que tem um real comprometimento com a oferta de produtos sustentáveis, e que investiram recursos substanciais para fazer com que seus processos produtivos tivessem um menor impacto ambiental. Ainda em relação ao consumidor, é possível notar que existe uma falta de

\footnotetext{
${ }^{7}$ O termo "penetração" refere-se ao conceito de marketing "penetração de mercado", que busca avaliar o número de pessoas que realmente compram determinados produtos.
} 
conhecimento geral acerca das certificações, além de falta de compreensão sobre a mensagem que está sendo transmitida e, ainda, de valorização dos mesmos no momento de realizar a compra (D’Souza et al., 2006; J. Morris, 1997; Pedersen \& Neergaard, 2006; SustainAbility, 2011). Mesmo entre os demais stakeholders, nota-se uma dificuldade em compreender o valor que os mesmos podem oferecer aos negócios (Iseal Alliance, 2010).

Uma barreira citada por diversos autores são os custos envolvidos no processo das certificações. Pinto e Granja (2013, p.7), mapearam e dividiram os custos para obtenção das certificações de manejo florestal da seguinte maneira: i) custos para a obtenção do certificado: treinamentos, documentação em geral, auditorias internas, contratação de consultorias para apoiar as diversas etapas e a contratação da entidade certificadora; ii) custos para a adequação de manejo sustentável: infraestrutura, instituição dos planos de manejo e cumprimento da legislação vigente; e iii) custos referentes à manutenção do certificado: auditorias anuais para verificação, manutenção de documentos e registros, treinamentos e outras atividades. À exceção do manejo, que está ligado a gestão florestal, todos os demais custos deveriam ser considerados pelas empresas fornecedoras de insumos que planejassem obter a certificação, além das empresas de bens de consumo que utilizem a celulose ou outros insumos florestais na fabricação de seus produtos.

Além do investimento financeiro, também são levantadas outras questões internas das empresas, como: i) o nível de exigência das certificadoras em relação aos padrões que devem ser cumpridos, que podem ser muito altos e excluir, de forma não intencional, a maioria dos produtores; ou muito baixos, ficando difícil buscar diferenciação, dado que muitas empresas e/ou produtos podem obtê-los (Piotrowski e Kratz, 2005); ii) o prazo para se obter a certificação, que pode ser muito longo, desestimulando os colaboradores envolvidos (Iseal Alliance, 2010); iii) as dificuldades para fazer a implementação, que demanda muitas informações (SustainAbility, 2011), confecção e atualização de documentos específicos, a disponibilidade de tempo dos colaboradores, realização de auditorias internas, dentre diversas outras atividades (Pinto e Granja, 2013); iv) o quanto a estrutura organizacional está preparada para realizar tais procedimentos (Iseal Alliance, 2010), dado que, por exemplo, em alguns casos os colaboradores tem baixa escolaridade, mas demanda-se manuseio de ferramentas estatísticas da qualidade (Pinto e Granja, 2013); e vi) a competição de espaço na embalagem entre diversos atributos do produto a serem comunicados, sendo que muitas vezes 
os próprios designers não querem colocar a certificação em suas peças criativas (SustainAbility, 2011).

Após avaliar todas as questões internas, surgem outros obstáculos, que são externos às empresas, como: i) o quanto a cadeia de fornecimento está preparada para participar do processo de certificação, dado que percebe-se uma dificuldade de se obter informações confiáveis relacionadas a aspectos socioambientais da cadeia produtiva (SustainAbility, 2011) e/ou encontrar fornecedores que produzam produtos certificados (Ham, 2007); e ii) o quanto as próprias certificadoras e padronizadoras estão preparadas para dar conta do aumento da demanda, seja por falta de capacidade operacional (Iseal Alliance, 2010), por impossibilidade e/ou falta de relevância de se abranger todos os insumos utilizados pelas empresas (Vark, 2016), ou pelo risco de se concentrar o fornecimento em poucos fornecedores que tenham certificação (SustainAbility, 2011)

Diante de tantos empenho e investimento que se fazem necessários, tanto por parte das empresas, quanto por parte de diversos outros stakeholders da cadeia, ainda restam dúvidas se este esforço demandado no processo é compensado pelos benefícios gerados, tanto ambientais (Golden, 2010; Piotrowski \& Kratz, 2005), quanto financeiros (Ham, 2007) e/ou de valorização do mercado (SustainAbility, 2011). A mensuração dos impactos causados pelas suas atividades foi identificada por Golden (2010) como um dos critérios para o sucesso das certificações, porém detectou-se que a maioria das organizações padronizadoras não faz esse tipo de acompanhamento. Há dúvidas, inclusive, em relação ao quanto a adoção de certificações não são uma barreira à inovação, dado que "os critérios somente podem ser calcados no conhecimento existente, quer dos produtos, quer das tecnologias e das questões ambientais" (CEMPRE \& ABRE, n.d., p. 13), e ao quanto estes esquemas vão ser relevantes no futuro, como será sua evolução e como se comportará sua demanda (SustainAbility, 2011).

Um outro tema encontrado está relacionado ao processo de definição de critérios das certificações, no qual muitas vezes as organizações padronizadoras falham ao não envolverem os diversos stakeholders da cadeia para considerar o ponto de vista do maior número de interessados possível, ou envolverem demais apenas alguns deles, distorcendo as questões que serão endereçadas pelo esquema de acordo com seus interesses (Morris, 1997). Um outro stakeholder muito citado é o governo, e sua falta de atuação no que tange a diminuir o número 
de selos existentes (em seu papel de legislador), e também a inserir as certificações como critérios de compras públicas, a fim de estimular os negócios (em seu papel de comprador) (Bruce \& Laroiya, 2007; Gadema \& Oglethorpe, 2011; Horne, 2009; Polonsky et al., 1998; Sønderskov \& Daugbjerg, 2011).

Ao procurarem oferecer uma visão geral sobre os apelos ambientais como um instrumento de política ambiental no contexto de uma economia globalizada, Piotrowski e Kratz (2005) também levantaram diversos problemas em relação ao processo de obtenção das certificações e seu uso em contexto global, como dificuldade de se estabelecer padrões que sejam relevantes globalmente, dado que cada região tem prioridades ambientais diferentes, e a descentralização de operações das empresas, o que amplia carteira de fornecedores e abre espaço para subcontratações, o que dificulta a rastreabilidade.

Estas foram as barreiras encontradas pelas empresas de bens de consumo na adoção das certificações. Note-se que, além de artigos acadêmicos, foram usados como fonte de dados os relatórios de instituições como a ISEAL (Iseal Alliance, 2010) e a SustainAbility (SustainAbility, 2011), e reportagens de mercado (Vark, 2016), a fim de aumentar a abrangência do estudo. A consolidação dos achados da revisão bibliográfica pode ser visualizada na Tabela 7 , a seguir.

Tabela 7 - Barreiras às certificações sustentáveis enfrentadas pelas empresas

(continua)

\begin{tabular}{l|l|l|l}
\hline Barreira & Descrição & Autores \\
\hline 1 & $\begin{array}{l}\text { Aumento de } \\
\text { custos }\end{array}$ & $\begin{array}{l}\text { Pode haver um investimento inicial para realizar as } \\
\text { certificações, além de investimentos periódicos para } \\
\text { manutenção das mesmas; } \\
\text { Empresas eventualmente devem fazer adaptações em } \\
\text { seus processos internos para se prepararem para } \\
\text { certificação; } \\
\text { Custo de insumos certificados pode ser maior que de } \\
\text { insumos sem certificação. }\end{array}$ & $\begin{array}{l}\text { (Ham, 2007; } \\
\text { Piotrowski \& Kratz, } \\
2005 ; \text { Rubik et al., } \\
2008 ; \text { SustainAbility, } \\
2011)\end{array}$ \\
\hline $\begin{array}{l}\text { Prazos para } \\
\text { adequar } \\
\text { processos e } \\
\text { realizar a } \\
\text { certificação }\end{array}$ & $\begin{array}{l}\text { Processo de adequação a padrões pode ser muito longo, } \\
\text { desestimulando colaboradores. }\end{array}$ & $\begin{array}{l}\text { (Golden, 2010; Iseal } \\
\text { Alliance, 2010) }\end{array}$ \\
\hline
\end{tabular}


(continuação)

\begin{tabular}{|c|c|c|c|}
\hline & Barreira & Descrição & Autores \\
\hline 3 & $\begin{array}{l}\text { Nível dos } \\
\text { padrões }\end{array}$ & $\begin{array}{l}\text { Revisões nos critérios são constantes; } \\
\text { Exigências muito altas acabam excluindo, de forma não } \\
\text { intencional, a maioria dos produtores. } \\
\text { Se critérios são muito baixos, fica difícil buscar } \\
\text { diferenciação. }\end{array}$ & $\begin{array}{l}\text { (Gallastegui, 2002; } \\
\text { Ham, 2007; Piotrowski } \\
\text { \& Kratz, 2005; } \\
\text { SustainAbility, 2011) }\end{array}$ \\
\hline 4 & $\begin{array}{l}\text { Imprevisibilidade } \\
\text { da demanda para } \\
\text { produtos } \\
\text { certificados }\end{array}$ & $\begin{array}{l}\text { Muito se fala sobre o aumento da demanda por produtos } \\
\text { sustentáveis, mas na prática empresários ainda não } \\
\text { captaram essa tendência e/ou não conseguiram mensurar } \\
\text { este potencial; } \\
\text { Lacuna entre discurso ambientalmente correto por parte } \\
\text { de consumidores versus sua prática no momento da } \\
\text { compra; } \\
\text { Falta conhecimento sobre como consumidores } \\
\text { reconhecem e interpretam as certificações; } \\
\text { Produtos podem não atender a expectativa dos } \\
\text { consumidores em relação ao preço, performance ou } \\
\text { qualidade. }\end{array}$ & $\begin{array}{l}\text { (Cornelissen et al., } \\
\text { 2007; D’Souza, 2004; } \\
\text { Gallastegui, 2002; } \\
\text { Hartikainen et al., } \\
\text { 2014; Iseal Alliance, } \\
\text { 2010; Lacy, 2013; } \\
\text { Pedersen \& Neergaard, } \\
\text { 2006; SustainAbility, } \\
\text { 2011) }\end{array}$ \\
\hline 5 & $\begin{array}{l}\text { Diversas } \\
\text { certificações } \\
\text { existentes no } \\
\text { mercado }\end{array}$ & $\begin{array}{l}\text { Sobreposição de padrões, dificuldade para diferenciá- } \\
\text { los, falta de informações sobre cada um; } \\
\text { Incertezas relacionadas a oferta e credibilidade de } \\
\text { diversas padronizadoras e certificadoras, não só entre as } \\
\text { empresas, mas perante outros stakeholders; } \\
\text { "Penalização" para empresas com maior } \\
\text { comprometimento, devido à confusão causada pelo } \\
\text { grande número de apelos sustentáveis } \\
\text { Incertezas em relação ao nível de compreensão e } \\
\text { valorização por parte dos consumidores. }\end{array}$ & $\begin{array}{l}\text { (Brécard, 2014; } \\
\text { Gallastegui, 2002; J. } \\
\text { Morris, 1997; Ottman } \\
\text { et al., 2006; Piotrowski } \\
\text { \& Kratz, 2005; } \\
\text { Roberts, 1996) }\end{array}$ \\
\hline 6 & $\begin{array}{l}\text { Maquiagem } \\
\text { verde }\end{array}$ & $\begin{array}{l}\text { Apelos sustentáveis perderam credibilidade com o } \\
\text { passar do tempo devido a quantidade de apelos inseridos } \\
\text { no mercado sem a devida contrapartida por parte da } \\
\text { empresa. }\end{array}$ & $\begin{array}{l}\text { (Pedersen \& } \\
\text { Neergaard, 2006; } \\
\text { Polonsky et al., 1998; } \\
\text { Prothero, 1997) }\end{array}$ \\
\hline 7 & $\begin{array}{l}\text { Falta de } \\
\text { ferramentas e } \\
\text { consequente } \\
\text { dificuldade para } \\
\text { mensurar } \\
\text { impactos }\end{array}$ & $\begin{array}{l}\text { Incerteza em relação aos impactos efetivos da } \\
\text { certificação no meio ambiente e/ou na sociedade; } \\
\text { Falta de bancos de dados e informações; } \\
\text { Falta de garantias sobre informações disponíveis; } \\
\text { Dificuldade em saber quais são os melhores materiais } \\
\text { disponíveis. }\end{array}$ & $\begin{array}{l}\text { (Gallastegui, 2002; } \\
\text { Golden, 2010; Horne, } \\
\text { 2009; Nebel, Quevedo, } \\
\text { Bredahl Jacobsen, \& } \\
\text { Helles, 2005; Rubik et } \\
\text { al., 2008; } \\
\text { SustainAbility, 2011) } \\
\end{array}$ \\
\hline 8 & $\begin{array}{l}\text { Falta de } \\
\text { comprovação dos } \\
\text { benefícios da } \\
\text { certificação }\end{array}$ & $\begin{array}{l}\text { Indagação se investimentos necessários são } \\
\text { compensados. }\end{array}$ & $\begin{array}{l}\text { (Ham, 2007; } \\
\text { Piotrowski \& Kratz, } \\
\text { 2005; SustainAbility, } \\
\text { 2011) }\end{array}$ \\
\hline
\end{tabular}


(continuação)

\begin{tabular}{|c|c|c|c|}
\hline & Barreira & Descrição & Autores \\
\hline 9 & $\begin{array}{l}\text { Processo de } \\
\text { definição de } \\
\text { critérios e/ou } \\
\text { mensuração das } \\
\text { certificações }\end{array}$ & $\begin{array}{l}\text { Critérios definidos com base em interesses próprios, } \\
\text { baseados em percepções ou questões políticas, não em } \\
\text { ciência; } \\
\text { Não há uma metodologia definitiva aceita pelos diversos } \\
\text { stakeholders envolvidos no processo; } \\
\text { Dificuldades em se comparar ciclos de vida de produtos } \\
\text { tão diferentes; } \\
\text { Padrões muito dominados pelos grupos de interesse e/ou } \\
\text { suscetíveis aos mesmos; } \\
\text { Falta de transparência por parte das certificadoras e/ou } \\
\text { padronizadoras. }\end{array}$ & $\begin{array}{l}\text { (Gallastegui, 2002; Iles } \\
\text { \& Martin, 2013; Iseal } \\
\text { Alliance, 2010; J. } \\
\text { Morris, 1997; } \\
\text { Piotrowski \& Kratz, } \\
\text { 2005; Rubik et al., } \\
\text { 2008; SustainAbility, } \\
\text { 2011) }\end{array}$ \\
\hline 10 & $\begin{array}{l}\text { Aumento da } \\
\text { complexidade da } \\
\text { cadeia de } \\
\text { custódia com } \\
\text { aumento da } \\
\text { globalização }\end{array}$ & $\begin{array}{l}\text { Dificuldade de se estabelecer padrões que sejam } \\
\text { relevantes globalmente, dado que cada região tem } \\
\text { prioridades ambientais diferentes; } \\
\text { Dificuldade de mensurar impactos com fornecimento } \\
\text { sendo realizados a partir de diversas regiões; } \\
\text { Descentralização de operações das empresas, o que } \\
\text { amplia carteira de fornecedores e abre espaço para sub- } \\
\text { contratações, o que dificulta a rastreabilidade; } \\
\text { Produtores de países em desenvolvimento podem } \\
\text { enfrentar dificuldades de entrada em países } \\
\text { desenvolvidos; } \\
\text { Regras estabelecidas em acordos internacionais de } \\
\text { comércio. }\end{array}$ & $\begin{array}{l}\text { (Cohen \& } \\
\text { Vandenbergh, 2012; } \\
\text { Compromisso } \\
\text { Empresarial para } \\
\text { Reciclagem - } \\
\text { CEMPRE, n.d.; } \\
\text { Gallastegui, 2002; J. } \\
\text { Morris, 1997; Nebel et } \\
\text { al., 2005; Piotrowski \& } \\
\text { Kratz, 2005) }\end{array}$ \\
\hline 11 & Escala & $\begin{array}{l}\text { Tamanho e capacidade das padronizadoras e } \\
\text { certificadoras; } \\
\text { Muitos esquemas ainda são de nicho, não tendo escala } \\
\text { necessária para atender grandes empresas. }\end{array}$ & $\begin{array}{l}\text { (Iseal Alliance, 2010; } \\
\text { Sustain Ability, 2011) }\end{array}$ \\
\hline 12 & $\begin{array}{l}\text { Design das } \\
\text { embalagens }\end{array}$ & $\begin{array}{l}\text { Falta de espaço na embalagem para comunicar } \\
\text { certificação; } \\
\text { Designers que não querem colocar a certificação em } \\
\text { suas peças criativas. }\end{array}$ & (SustainAbility, 2011) \\
\hline 13 & $\begin{array}{l}\text { Incerteza em } \\
\text { relação ao futuro }\end{array}$ & $\begin{array}{l}\text { Dúvidas sobre aumento ou não da demanda por } \\
\text { certificações; } \\
\text { Dúvidas sobre como papel das certificações vai se } \\
\text { desenvolver. }\end{array}$ & $\begin{array}{l}\text { (Iseal Alliance, 2010; } \\
\text { SustainAbility, 2011) }\end{array}$ \\
\hline 14 & Inibe inovação & $\begin{array}{l}\text { Para atender requisitos empresas acabam não investindo } \\
\text { em melhorias nos produtos certificados. }\end{array}$ & $\begin{array}{l}\text { (CEMPRE \& ABRE, } \\
\text { n.d; Gallastegui, 2002; } \\
\text { J. Morris, 1997; } \\
\text { SustainAbility, 2011) }\end{array}$ \\
\hline
\end{tabular}


(conclusão)

\begin{tabular}{|c|c|c|c|}
\hline & Barreira & Descrição & Autores \\
\hline 15 & $\begin{array}{l}\text { Conexão entre } \\
\text { marcas (da } \\
\text { empresa e da } \\
\text { padronizadora) }\end{array}$ & $\begin{array}{l}\text { Se houver algum problema com a padronizadora, a } \\
\text { marca da empresa também poderá ser afetada. }\end{array}$ & (SustainAbility, 2011) \\
\hline 16 & $\begin{array}{l}\text { Esforço de } \\
\text { coordenação e } \\
\text { complexidade }\end{array}$ & $\begin{array}{l}\text { Demanda por muitas informações; } \\
\text { Necessidade de realização de auditorias e treinamentos } \\
\text { internos; } \\
\text { Complexidade das operações realizadas; } \\
\text { Necessidade de disponibilizar tempo dos colaboradores } \\
\text { para auxiliar na implantação; } \\
\text { Diversos documentos (oficiais ou não) com orientações } \\
\text { de como fazer uso de comunicações sustentáveis; } \\
\text { Exigências em relação à aplicações das marcas. }\end{array}$ & $\begin{array}{l}\text { (Golden, 2010; Ham, } \\
\text { 2007; Iseal Alliance, } \\
\text { 2010; Pinto \& Granja, } \\
\text { 2013; Roberts, 1996; } \\
\text { SustainAbility, 2011) }\end{array}$ \\
\hline 17 & $\begin{array}{l}\text { Estrutura } \\
\text { organizacional } \\
\text { das empresas }\end{array}$ & $\begin{array}{l}\text { Estrutura não preparada para lidar com certificações } \\
\text { sustentáveis; } \\
\text { Necessidade de a alta gestão ser mais envolvida com o } \\
\text { tema; } \\
\text { Baixa escolaridade de colaboradores, dificuldades em } \\
\text { mexer nas ferramentas. }\end{array}$ & $\begin{array}{l}\text { (Iseal Alliance, 2010; } \\
\text { Pinto \& Granja, 2013) }\end{array}$ \\
\hline 18 & $\begin{array}{l}\text { Problemas de } \\
\text { fornecimento }\end{array}$ & $\begin{array}{l}\text { Não encontra fornecedores que tenham certificação; } \\
\text { No caso de matérias primas, limita flexibilidade de } \\
\text { fornecimento para poucos fornecedores certificados; } \\
\text { Não conseguem obter informações de toda a cadeia de } \\
\text { fornecimento. }\end{array}$ & $\begin{array}{l}\text { (Ham, 2007; } \\
\text { SustainAbility, 2011) }\end{array}$ \\
\hline 19 & $\begin{array}{l}\text { Falta de } \\
\text { reconhecimento } \\
\text { e valorização }\end{array}$ & $\begin{array}{l}\text { Certificações não são consideradas como fator de } \\
\text { decisão de compra } \\
\text { A adoção de certificações não é valorizada pelos } \\
\text { stakeholders }\end{array}$ & $\begin{array}{l}\text { (D’Souza et al., 2006; } \\
\text { J. Morris, 1997; } \\
\text { Pedersen \& Neergaard, } \\
\text { 2006; SustainAbility, } \\
\text { 2011, Iseal Alliance, } \\
\text { 2010) }\end{array}$ \\
\hline 20 & $\begin{array}{l}\text { Falta de maior } \\
\text { posicionamento } \\
\text { do poder público }\end{array}$ & $\begin{array}{l}\text { Falta de atuação do governo em desenvolver e/ou } \\
\text { identificar padrões que fossem oficiais, a fim de orientar } \\
\text { melhor empresas e consumidores, e limitando a } \\
\text { proliferação de certificações } \\
\text { Falta de inserção das certificações como requisitos de } \\
\text { compras públicas }\end{array}$ & $\begin{array}{l}\text { (Bruce \& Laroiya, } \\
\text { 2007; Gadema \& } \\
\text { Oglethorpe, 2011; } \\
\text { Horne, 2009; Polonsky } \\
\text { et al., 1998; } \\
\text { Sønderskov \& } \\
\text { Daugbjerg, 2011) }\end{array}$ \\
\hline
\end{tabular}

Fonte: organizado pela autora com base no levantamento bibliográfico. 


\section{ASPECTOS METODOLÓGICOS}

Como foi apresentado na revisão bibliográfica, diversas são as barreiras para uma maior utilização das certificações sustentáveis por parte das empresas. Porém, foi possível notar que os estudos acadêmicos realizados até o momento não tinham foco em levantar e sistematizar estas barreiras, mas que elas surgiam quando de outras discussões a respeito do tema, realizadas com as mais diversas metodologias e com diversos grupos de interesse. Com isso, percebe-se uma lacuna na literatura atual em relação à sistematização das barreiras para a adoção das certificações sustentáveis, e conclui-se pela necessidade da realização de uma pesquisa de campo a fim de aprofundar o conhecimento sobre o tema.

Para Hesse-Biber e Leavy (2011) quando da seleção de método para um projeto de pesquisa é muito importante que se estabeleça uma ligação entre o objetivo que se quer alcançar e o método selecionado. Os autores citam três objetivos de pesquisa primários: i) exploratório, que busca investigar aspectos pouco pesquisados da vida social; ii) descritivo, que busca descrever de forma detalhada algum aspecto da vida social; e iii) explanatório, que busca explicar aspectos da vida social. Marshall e Rossman (2015) citam também um quarto objetivo - o emancipatório, além de indicar quais seriam as principais questões de pesquisa que estariam relacionadas a cada objetivo, conforme Tabela 8.

O objetivo geral do presente estudo é propor uma sistematização das barreiras que dificultam a utilização das certificações sustentáveis por parte de empresas de bens de consumo - ou seja, busca-se investigar um aspecto que ainda foi pouco explorado dentro do contexto da rotulagem sustentável. Já entre os objetivos específicos, busca-se compreender melhor como se dá o processo de implementação destas certificações, mapeando o processo de decisão a fim de que seja possível avaliar como as barreiras atuam, levantar outras questões relacionadas à adoção das certificações, como motivações, prazos envolvidos, investimento necessários e impactos causados, que áreas da empresa são envolvidas com o tema, e se há semelhanças entre certificações distintas. Com isso, pode-se dizer que a pesquisa exploratória seria as mais apropriadas para o estudo, dado que se busca uma maior compreensão sobre o tema das barreiras às certificações sustentáveis. O foco principal desse estudo é a descoberta de novas ideias e possíveis relações que poderão ser utilizadas em futuros estudos. 
Tabela 8 - Ligando questões de pesquisa com o objetivo

\begin{tabular}{l|l}
\hline Objetivo do estudo & Questões gerais de pesquisa \\
\hline $\begin{array}{l}\text { EXPLORATÓRIO } \\
\begin{array}{l}\text { Investigar fenômenos pouco compreendidos } \\
\text { Identificar ou descobrir categorias de } \\
\text { significados importantes } \\
\text { Gerar hipóteses para pesquisas futuras }\end{array}\end{array}$ & $\begin{array}{l}\text { O que está acontecendo neste programa social? } \\
\text { Quais são os temas, padrões ou categorias de significado } \\
\text { relevantes para os participantes? } \\
\text { Como estes padrões são relacionados uns com os outros? }\end{array}$ \\
\hline $\begin{array}{l}\text { EXPLANATÓRIO } \\
\text { Explicar os padrões relacionados com o } \\
\text { fenômeno em questão } \\
\begin{array}{l}\text { Identificar relações plausíveis que moldam } \\
\text { os fenômenos }\end{array}\end{array}$ & $\begin{array}{l}\text { Quais eventos, crenças, atutudes ou políticas moldam esse } \\
\text { fenômeno? } \\
\text { Como essas forças interagem para resultar no fenômeno? }\end{array}$ \\
\hline $\begin{array}{l}\text { DESCRITIVO } \\
\text { Documentar e descrever o fenômeno de } \\
\text { interesse }\end{array}$ & $\begin{array}{l}\text { Quais são os comportamentos salientes, eventos, crenças, } \\
\text { atitudes, estruturas, processos ocorrendo neste fenômeno? }\end{array}$ \\
\hline $\begin{array}{l}\text { EMANCIPATÓRIO } \\
\text { Criar oportunidades e a vontade para } \\
\text { engajamento na ação social }\end{array}$ & $\begin{array}{l}\text { Como os participantes problematizam suas circunstâncias e } \\
\text { tomam ação social positiva? }\end{array}$ \\
\hline
\end{tabular}

Fonte: Marshall e Rossman (2015, p.78)

Hesse-Biber e Leavy (2011) defendem que a abordagem qualitativa de pesquisa oferece uma fundamentação única sobre a forma de conduzir o estudo por meio de maneiras de fazer perguntas e pensar nos problemas, aplicando tipos de questões que geralmente começam com "como", "por que" ou "o que"/"quais". Os autores destacam que pesquisadores qualitativos estão em busca de extrair significados dos dados obtidos - significados sociais que as pessoas atribuem a suas experiências, circunstâncias e situações, assim como em textos e outros objetos. Já Pozzebon e Petrini (2013) citam a riqueza da pesquisa empírica, na qual as estruturas teóricas frequentemente norteiam a produção de diferentes significados para os dados coletados por meio de observações, conversas e as imagens criadas pelo próprio pesquisador.

\subsection{Método de pesquisa}

Definido o tipo de pesquisa, procedeu-se à escolha do método a ser utilizado para se alcançar o objetivo proposto. Segundo Yin (1994) o que distingue as estratégias de pesquisa são três condições, a saber: a) o tipo de questão colocada; b) a extensão do controle que o pesquisador tem sobre eventos comportamentais reais; e c) o nível de foco em eventos 
contemporâneos em oposição a eventos históricos. A Tabela 9 mostra estas três condições e como cada uma delas está relacionada com cinco das principais estratégias de pesquisa nas ciências sociais.

Tabela 9 - Situações relevantes para diferentes estratégias de pesquisa

\begin{tabular}{l|l|l|l}
\hline \multicolumn{1}{|c|}{ Estratégia } & $\begin{array}{c}\text { Forma da questão } \\
\text { de pesquisa }\end{array}$ & $\begin{array}{c}\text { Exige controle sobre } \\
\text { eventos comportamentais? }\end{array}$ & $\begin{array}{l}\text { Enfoque em acontecimentos } \\
\text { contemporâneos? }\end{array}$ \\
\hline Experimento & Como, por que & Sim & Sim \\
\hline Levantamento & $\begin{array}{l}\text { Quem, o que, onde, } \\
\text { quantos, quanto }\end{array}$ & Não & Sim \\
\hline Análise de arquivos & $\begin{array}{l}\text { Quem, o que, onde, } \\
\text { quantos, quanto }\end{array}$ & Não & Sim / não \\
\hline Pesquisa histórica & Como, por que & Não & Não \\
\hline Estudo de caso & Como, por que & Não & Sim \\
\hline
\end{tabular}

Fonte: COSMOS Corporation apud Yin (1994, p.6)

Dado que na presente pesquisa: a) busca-se compreender como se dá o processo de implementação de certificações sustentáveis por parte das empresas, a fim de levantar barreiras e formas de superá-las; b) não há exigência de controle sobre eventos comportamentais; e c) o foco está em acontecimentos contemporâneos, optou-se pelo método do estudo de caso, conforme sugerido por Yin (1994).

Para Eisenhardt (1989) o estudo de caso é uma estratégia de pesquisa que busca a compreensão da dinâmica presente em contextos únicos, e envolve a utilização de um ou mais casos para criar construtos, proposições e/ou teorias oriundas de evidências empíricas. A autora defende que, enquanto experimentos de laboratório isolam os fenômenos do seu contexto, os estudos de caso enfatizam a riqueza do contexto real no qual os fenômenos ocorrem, e comenta que a elaboração de teoria a partir desta estratégia é situada e desenvolvida por meio do reconhecimento de padrões de relações existentes entre construtos dentro de um caso e entre casos distintos, e todos os argumentos lógicos subjacentes. Siggelkow (2007) concorda que os casos podem aperfeiçoar a teoria dada, e comenta que isso é feito por meio da indicação das lacunas existentes e da proposta de como começar a preenchê-las. O autor também sugere que os casos são úteis ao ilustrar contribuições 
conceituais, e que uma das principais vantagens do método é a possibilidade de o pesquisador estar mais próximo aos construtos, o que permite uma maior clareza das relações causais existentes entre eles.

Ao se definir por utilizar o estudo de caso, deve-se elaborar o desenho da pesquisa que, segundo Yin (1994, p.20) deve conter cinco componentes importantes:

1. A questão da pesquisa - a tarefa inicial é deixar clara a natureza da pesquisa em relação ao tipo de pergunta, conforme exemplificado na segunda coluna da Tabela 8;

2. As proposições (caso existam) - cada proposição direciona a atenção para algo que deveria ser examinado no escopo do estudo. No caso de estudos exploratórios é factível que não se tenha proposições, porém, o autor sugere que se tenha um propósito e que se defina os critérios para que os resultados alcançados sejam bem sucedidos;

3. As unidades de análise - relacionado ao problema fundamental de definir o que é o "caso" - podem ser indivíduos, processos, decisões etc., e estão intimamente ligados à questão de pesquisa;

4. A lógica que faria a ligação entre os dados e as proposições - pode ser estabelecida de diversas maneiras, sendo que uma abordagem promissora seria a de “correspondência de padrões", na qual várias informações do mesmo caso podem estar relacionadas a alguma proposição teórica; e

5. Os critérios para interpretar os resultados - que devem ser definidos pelo pesquisador, dado que não há uma maneira precisa que determine como isso deve ser feito.

\subsection{A escolha do(s) caso(s) e unidades de análise}

A utilização de um ou mais casos já foi alvo de intenso debate entre os principais autores relacionados com o método da pesquisa de caso (Dyer \& Wilkins, 1991; Eisenhardt, 1991; Yin, 1994). Tanto Yin (1994) quanto Eisenhardt (1991) consideram os estudos de casos múltiplos mais robustos quanto à geração de teoria, mas ambos também reconhecem a 
existência e relevância dos estudos de caso únicos. Para Yin (1994), a utilização de caso único se faz justificável quando i) o caso representa um teste decisivo à uma teoria já existente, seja para confirma-la, para contesta-la, ou para estendê-la; ii) quando representa um evento raro ou extremo; ou iii) quando o caso serve como um propósito revelador - uma situação em que o pesquisador tem a chance de observar e analisar um fenômeno anteriormente inacessível à investigação científica. Outras alternativas possíveis estão relacionadas ao uso do método como uma introdução a um estudo mais apurado ou, ainda, como caso-piloto para a investigação posterior envolvendo outros casos.

Já os estudos de casos múltiplos são, para Eisenhardt (1991, p.620) "importante meio para criar teoria, pois permitem replicação e extensão entre casos individuais". A autora explica que a replicação significa que cada caso individual pode ser usado para corroborar com proposições específicas, o que ajuda o pesquisador a perceber padrões mais facilmente e a eliminar associações casuais. Já a extensão está relacionada ao uso de casos múltiplos para desenvolver uma teoria que seja mais elaborada, dado que casos diferentes geralmente enfatizam aspectos complementares de um mesmo fenômeno. Além dessas duas possibilidades, em outro artigo a autora também cita que casos múltiplos podem ser escolhidos para preencher categorias teóricas e prover exemplos de tipos contraditórios (Eisenhardt, 1989). Nesta mesma publicação, Eisenhardt cita que, enquanto os casos podem ser escolhidos aleatoriamente, esta aleatoriedade não se faz necessária nem preferível. As mesmas afirmações são feitas por Yin (1994), para quem cada caso deve ser selecionado de modo a prever resultados semelhantes (replicação literal) ou, inversamente, produzir resultados contrastantes por razões previsíveis (replicação teórica). O autor explica que esta lógica da replicação é diferente da lógica da amostragem normalmente utilizada em pesquisas quantitativas, na qual um determinado número de respondentes deveria representar uma população inteira.

Para atender aos objetivos da presente pesquisa considerou-se que o estudo de mais casos poderia apresentar um maior número de barreiras (semelhantes ou não às encontradas na teoria) e possibilitar ainda uma categorização mais robusta em relação aos tipos de barreiras relacionados a diferentes certificações e stakeholders, além de propiciar mapeamento de mais processos de adoção das certificações nas empresas avaliadas. Para Yin (1994), além da escolha entre casos únicos ou múltiplos, também se faz relevante escolher entre casos 
holísticos ou incorporados, conforme apresentado na Tabela 10. Segundo esta matriz, os quatro tipos de projetos são:

- Tipo 1: projetos de caso único (holísticos);

- Tipo 2: projetos de caso único (incorporados);

- Tipo 3: projetos de casos múltiplos (holísticos);

- Tipo 4: projetos de casos múltiplos (incorporados).

Tabela 10 - Tipos básicos de projetos para os estudos de caso

\begin{tabular}{|c|c|c|}
\hline & Projetos de caso único & $\begin{array}{c}\text { Projetos de casos } \\
\text { múltiplos }\end{array}$ \\
\hline $\begin{array}{c}\text { Holísticos } \\
\text { (unidade de análise única) }\end{array}$ & TIPO 1 & TIPO 3 \\
\hline $\begin{array}{c}\text { Incorporados } \\
\text { (unidades de análise múltiplas) }\end{array}$ & TIPO 2 & TIPO 4 \\
\hline
\end{tabular}

Fonte: COSMOS Corporation apud Yin (1994, p.39)

Note-se que a definição entre casos holísticos ou incorporados está relacionada ao número de unidades de análises estabelecidas (apenas uma ou mais do que uma). Segundo Yin (1994), alguns problemas podem surgir quando da utilização de casos holísticos, como a condução do estudo ser feito de uma forma mais abstrata e a necessidade de se re-iniciar o estudo caso quando do surgimento de algum outro tipo de orientação durante o estudo. Para o autor, ao se utilizar sub-unidades de análise, um projeto incorporado serve como um importante dispositivo para focar no objeto de pesquisa do estudo de caso.

Para a presente pesquisa definiu-se que as unidades de análise são os stakeholders envolvidos no processo de adoção das certificações sustentáveis pelas empresas de bens de consumo, conforme já apresentado no tópico 2.2 .2 (p.63-64): além das próprias empresas, seus fornecedores de insumos e as certificadoras e padronizadoras que estabelecem os padrões a serem seguidos.

Outra importante etapa foi selecionar quais seriam os casos a serem estudados. Para Eisenhardt e Graebner (2007), a escolha deve se basear menos na singularidade de um dado 
caso e mais na contribuição ao desenvolvimento da teoria dentro de um determinado conjunto de casos. Segundo as autoras, uma abordagem especificamente importante seria aquela que contém tipos opostos, na qual o pesquisador define casos extremos de forma a observar mais facilmente padrões contrastantes existentes nos dados encontrados.

Dada a existência de um grande número de certificações (conforme já demonstrado no tópico 2.1.5 do presente trabalho), a primeira etapa foi definir qual tipo de certificação ofereceria uma melhor fonte de dados para análise. Lembrando que foi proposta uma classificação para as certificações de acordo com sua abrangência (produto como um todo, empresa, parte do produto ou processo produtivo e/ou de comercialização - vide Tabela 2, p.36), esta mesma classificação foi utilizada no processo de escolha dos casos, conforme Tabela 11, que teve como objetivo avaliar as vantagens e desvantagens em se utilizar cada tipo de selo no presente estudo. Note-se que a escolha se deu por eleger casos extremos dentro de um mesmo tipo de certificação, a fim de manter a possibilidade comparação.

Tabela 11 - Vantagens e desvantagens de cada tipo de certificação para o estudo

\section{(continua)}

\begin{tabular}{l|l|l}
\hline Tipo de certificação & Vantagens em ser foco do estudo & Desvantagens em ser foco do estudo \\
\hline Empresa & $\begin{array}{l}\text { É um tipo de selo que valoriza as } \\
\text { empresas como um todo, não } \\
\text { somente os produtos por elas } \\
\text { produzidos. }\end{array}$ & $\begin{array}{l}\text { ISO tem 1.500 empresas certificadas } \\
\text { porém geralmente a certificação não é } \\
\text { aplicada na embalagem do produto. } \\
\text {. B Corp é uma certificação mais recente, } \\
\text { com poucas empresas de bens de } \\
\text { consumo certificadas }\end{array}$ \\
\hline $\begin{array}{l}\text { Produto como um } \\
\text { todo }\end{array}$ & $\begin{array}{l}\text { É certificação mais completa, por } \\
\text { considerar todo o ciclo de vida } \\
\text { (ACV) e/ou algum aspecto } \\
\text { específico (ex.: eficiência } \\
\text { energética) do produto como um } \\
\text { todo. }\end{array}$ & $\begin{array}{l}\text { Brasil relacionadas ao ACV; } \\
\text {. A certificação de eficiência energética é } \\
\text { controlada pelo Governo e compulsória, o } \\
\text { que dificultaria avaliar barreiras } \\
\text { encontradas para não adoção da mesma. }\end{array}$ \\
\hline $\begin{array}{l}\text { Parte do produto } \\
\text { (conteúdo ou } \\
\text { embalagem) }\end{array}$ & $\begin{array}{l}\text { Conta com certificações mais } \\
\text { robustas e com maior } \\
\text { disponibilidade no Brasil. }\end{array}$ & $\begin{array}{l}\text { Por ser focado em apenas uma parte do } \\
\text { produto, talvez não seja um diferencial } \\
\text { para o consumidor em seu processo de } \\
\text { escolha. }\end{array}$ \\
\hline
\end{tabular}

\footnotetext{
${ }^{8}$ Fonte: http://certifiq.inmetro.gov.br/Grafico/CertificadosValidosBrasil

${ }^{9}$ Fonte: http://www.sistemab.org/espanol/comunidad-empresas-b/busqueda-de-empresa-b/empresas-b-brasil
} 
(conclusão)

\begin{tabular}{l|l|l}
\hline Tipo de certificação & Vantagens em ser foco do estudo & Desvantagens em ser foco do estudo \\
\hline $\begin{array}{l}\text { Processo produtivo } \\
\text { e/ou comercialização }\end{array}$ & $\begin{array}{l}\text { Conta com certificações mais } \\
\text { robustas e com maior } \\
\text { disponibilidade no Brasil. }\end{array}$ & $\begin{array}{l}\text { - Muitos dos esquemas são específicos de } \\
\text { algumas categorias (ex.: pesca, café); } \\
\text {. Selo orgânico é regularizado pelo } \\
\text { governo, o que dificultaria comparações } \\
\text { entre casos. }\end{array}$ \\
\hline
\end{tabular}

Fonte: elaborada pela autora.

Ao analisar as vantagens e desvantagens de cada tipo de certificação, concluiu-se que a melhor opção seriam aquelas que contam com os esquemas mais robustos e com maior disponibilidade no Brasil - parte do produto, ou processo produtivo e/ou comercialização. Avaliando as desvantagens relacionadas a estas duas possibilidades, o selo orgânico não seria passível de comparação, dado que é regulamentado pelo governo; e os esquemas voltados para categorias específicas restringiriam a possibilidade de comparação entre casos. Portanto, optou-se pela primeira (parte de produto), pois sua desvantagem está mais relacionada à comunicação elaborada para o consumidor, que não é foco do presente estudo. Após considerar as opções de certificações relacionadas a parte do produto, foram selecionadas aquelas relacionadas à embalagens, como FSC e I'm Green, que estão dentre as mais conhecidas no país, segundo pesquisa de Market Analysis (2016). Uma diferença básica entre as duas se refere ao tipo de embalagem em que são aplicadas: o FSC está relacionado a produtos de origem florestal e é aplicado em embalagens de papel, e o "I'm Green" certifica a origem renovável de materiais plásticos.

Ao aprofundar a forma como cada stakeholder escolhido para o presente estudo tem acesso a estas certificações (vide Tabela 12) é possível notar que existe uma outra diferença sutil entre os dois casos, porém relevante de ser ressaltada: no caso do FSC, o fornecedor industrial que tem o papel de converter a matéria prima em outros insumos, que serão então fornecidos à empresa de bens de consumo, deve obter a certificação de cadeia de custódia, assim como o fornecedor de matéria prima, que deve obter certificação relacionada ao manejo florestal. No caso da certificação "I'm Green", o convertedor compra o insumo já certificado, oriundo de um fornecedor que teve que obter a certificação da origem de sua matéria prima. Além disso, no caso do FSC, há diversos fornecedores de matéria prima certificada, sendo que para o "I'm Green" somente uma empresa detém esta tecnologia atualmente, que foi 
desenvolvida em seus centros de pesquisa e tecnologia, e para qual criou-se o selo que identifica este produto.

Tabela 12 - Relação de cada tipo de stakeholder com as certificações escolhidas

\begin{tabular}{l|l|l}
\hline Organização & FSC & I'm Green \\
\hline $\begin{array}{l}\text { Empresa de bens de } \\
\text { consumo }\end{array}$ & $\begin{array}{l}\text { Compra insumo pronto e/ou deve } \\
\text { obter certificação (depende do tipo } \\
\text { de produto oferecido) }\end{array}$ & Compra insumo pronto \\
\hline $\begin{array}{l}\text { Empresa - fornecedor } \\
\text { industrial (convertedor) }\end{array}$ & Deve obter certificação & Compra insumo pronto \\
\hline $\begin{array}{l}\text { Empresa - fornecedor } \\
\text { industrial (de insumo) }\end{array}$ & Deve obter certificação & Deve obter certificação \\
\hline Certificadora & $\begin{array}{l}\text { Utiliza padrões estabelecidos para } \\
\text { certificar o manejo florestal e a } \\
\text { cadeia de custódia }\end{array}$ & $\begin{array}{l}\text { Utiliza padrões estabelecidos para } \\
\text { certificar origem renovável do } \\
\text { insumo na empresa que o fornece }\end{array}$ \\
\hline Padronizadora & $\begin{array}{l}\text { Estabelece os padrões a serem } \\
\text { seguidos }\end{array}$ & $\begin{array}{l}\text { Estabelece os padrões a serem } \\
\text { seguidos }\end{array}$ \\
\hline
\end{tabular}

Fonte: elaborada pela autora.

Sugere-se que os tipos diferentes de aplicação de cada certificação (plástico ou papel), e as diferentes formas de acessá-las, configuram a classificação dos dois casos como extremos. Acredita-se, desta forma, que esta composição estaria de acordo com o que é sugerido por Yin (1994) e Eisenhardt e Graebner (2007) como um bom desenho de pesquisa. Conforme mencionado por Miles e Huberman (1984), a definição da amostra na pesquisa qualitativa envolve duas ações principais: i) a necessidade de se estabelecer os limites do estudo - ou seja, definir os aspectos que poderão ser estudados, considerando a viabilidade de se responder a pergunta de pesquisa e também as limitações de tempo e ferramentas que estão disponíveis ao pesquisador; e ii) o desenvolvimento de um modelo conceitual que ajude a revelar, confirmar ou qualificar os constructos ou processos que fundamentam o estudo.

A partir de tais definições, seguiu-se para o planejamento do estudo que, segundo Yin (1994) deveria seguir o processo demonstrado na Figura 9. Note-se que cada caso deve ser analisado individualmente, para depois ser realizada a análise comparativa entre eles. Vale ressaltar que no método proposto pelo autor o pesquisador deve estar preparado para analisar casos adicionais, caso sejam necessários, para se atingir o objetivo de pesquisa. 


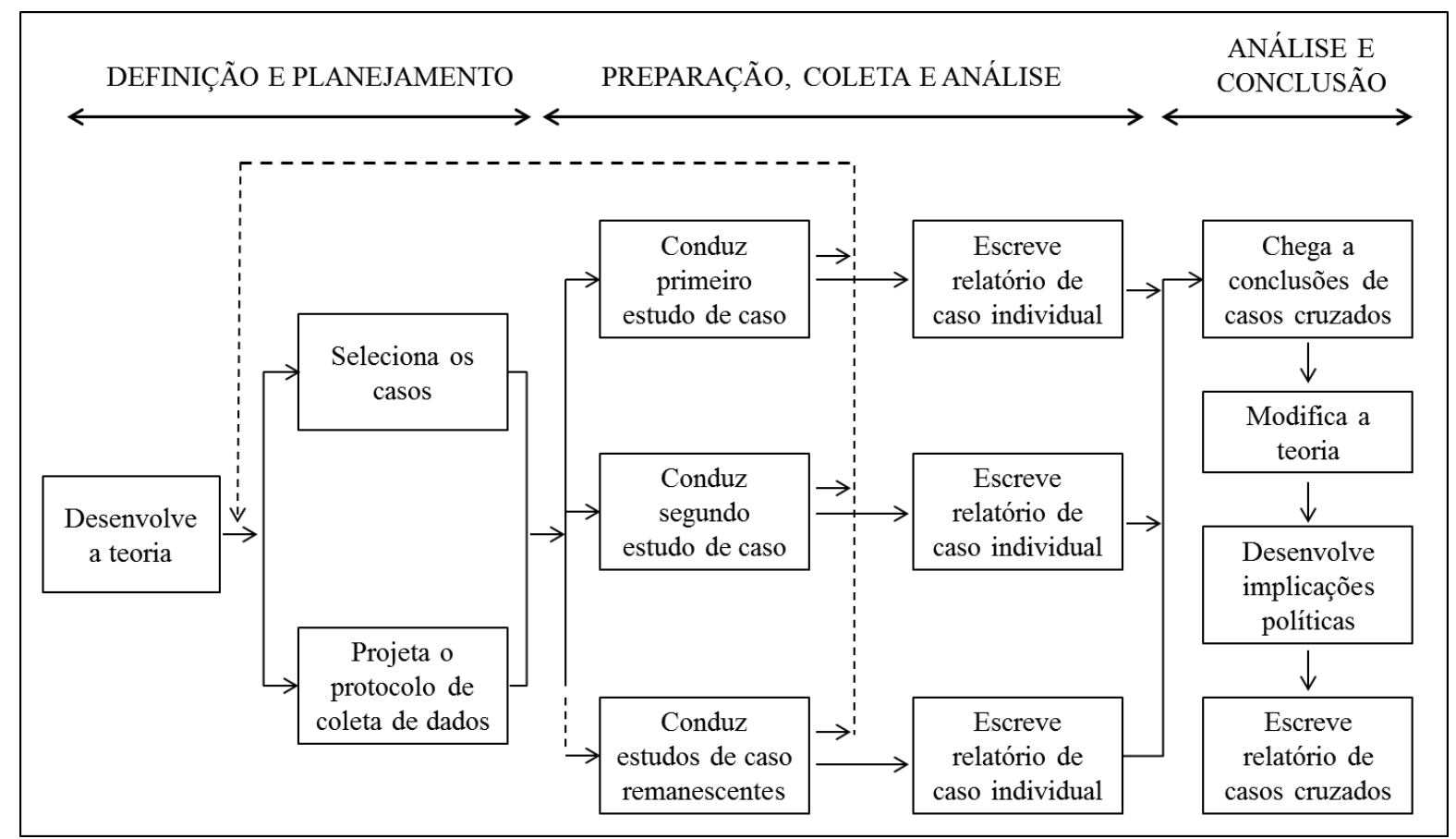

Figura 9 - Processo do estudo de caso

Fonte: COSMOS Corporation apud Yin (1994, p.49)

\subsection{A qualidade da pesquisa empírica}

Um dos argumentos centrais do artigo de Eisenhardt (1989) se refere à importância do rigor metodológico ao se realizar um estudo de caso, para o qual a autora descreve todo o processo a ser seguido, incluindo a necessidade de se identificar as questões de pesquisa, desenvolver instrumentos bem elaborados de coleta - como roteiros de entrevista e questionários, considerar amostragem teórica e controles, dentre outras etapas.

O mesmo depreende-se do livro de Yin (1994), que cita quatro testes que são costumeiramente usados para estabelecer a qualidade de qualquer pesquisa empírica das ciências sociais e, como os estudos de caso são uma forma deste tipo de pesquisa empírica, tais testes podem também ser considerados relevantes para garantir a qualidade do processo e dos resultados alcançados:

- Validade do constructo - estabelecer medidas operacionais corretas para os construtos que estão sendo pesquisados; 
- Validade interna - estabelecer uma relação causal por meio da qual certas condições levam a outras condições, ao contrário de relações inexistentes (critério utilizado somente em estudos causais);

- Validade externa - estabelecer até onde os resultados do estudo podem ser generalizados, ou seja, quando demonstra que algo é verdadeiro para além dos limites do estudo;

- Confiabilidade - demonstrar que as etapas do estudo (como os procedimentos de coleta de dados) podem ser repetidas obtendo-se os mesmos resultados.

Yin (1994) foi além de somente listar os testes, identificando quais seriam as táticas utilizadas em estudos de casos que são relacionadas a cada um deles, assim como uma referência de qual fase do estudo elas deveriam ser usadas. O resultado deste exercício está apresentado na Tabela 13, a seguir.

Tabela 13 - Táticas do estudo de caso para quatro testes de projeto

\begin{tabular}{l|l|l}
\multicolumn{1}{c|}{ Testes } & \multicolumn{1}{|c}{ Tática do estudo de caso } & \multicolumn{1}{c}{$\begin{array}{c}\text { Fase da pesquisa na qual } \\
\text { a tática deve ser aplicada }\end{array}$} \\
\hline \multirow{4}{*}{$\begin{array}{l}\text { Validade do } \\
\text { constructo }\end{array}$} & - Utiliza fontes múltiplas de evidências & Coleta de dados \\
\cline { 2 - 3 } & - Estabelece encadeamento de evidências & Coleta de dados \\
\cline { 2 - 3 } & $\begin{array}{l}\text { - O rascunho do relatório de estudo de caso é } \\
\text { revisado por informantes-chave }\end{array}$ & Composição \\
\hline \multirow{2}{*}{ Validade interna } & - Faz adequação ao padrão & Análise de dados \\
\cline { 2 - 3 } & - Faz construção da explanação & Análise de dados \\
\cline { 2 - 3 } & - Faz análise de séries temporais & Análise de dados \\
\hline \multirow{2}{*}{ Validade externa } & $\begin{array}{l}\text { - Utiliza lógica de replicação em estudos de casos } \\
\text { múltiplos }\end{array}$ & Projeto de pesquisa \\
\hline \multirow{2}{*}{ Confiabilidade } & - Utiliza protocolo de estudo de caso & Coleta de dados \\
\cline { 2 - 4 } & - Desenvolve banco de dados para o estudo de caso & Coleta de dados \\
\hline
\end{tabular}

Fonte: COSMOS Corporation apud Yin (1994, p.33) 
Eisenhardt (1989) também propõe algumas formas de avaliar a pesquisa que faz uso de estudos de caso. Primeiramente, ela cita Pfeffer (1982), ao dizer que um bom estudo deve resultar numa boa teoria (que seja parcimoniosa, testável e logicamente coerente), que surge ao final do estudo, e não em seu início. Em segundo lugar, deve mostrar a força do processo que foi desenhado e a evidência que norteia a teoria, provendo informações sobre a amostra, os procedimentos de coletas de dados e análises. Por último, a autora cita que uma boa pesquisa deveria resultar em novos insights.

Por fim, vale citar o artigo de Gibbert e Ruigrok (2010) que versa sobre a questão da qualidade do método de estudo de caso por meio da análise de diversos estudos de casos publicados ao longo de cinco anos em dez jornais acadêmicos de gestão. Os autores consideram os mesmos quatro testes sugeridos por Yin (1994) e voltam a atenção para quais deles são utilizados e reportados nos artigos, além de apresentar como os autores podem melhor reportar essas ações a fim de garantir a qualidade do trabalho que é publicado. Comparando as práticas de artigos que adressam a questão da qualidade com maior e menor ênfase, Gibbert e Ruigrok (2010) sugerem, então, as três estratégias que melhor garantem o rigor do estudo, sendo que a primeira está relacionada com "o que" é reportado e as outras duas com "como" as ações são reportadas:

- "Talk the walk" - reportar ações concretas em vez de critérios abstratos sugeridos pelos autores que versam sobre a metodologia;

- "Priorizar os tipos de validade" - priorizar cuidadosamente os tipos mais fundamentais de rigor que, segundo os autores, seriam a validade interna e a validade de constructo; e

- “Necessidade é a mãe do rigor" - fazer uso criativo dos contratempos que surgem durante o processo e tirar o melhor proveito dos recursos existentes.

\subsection{Coleta de dados}

Após realizar todo o desenho da pesquisa deve-se planejar como será feita a coleta dos dados a serem analisados. Para Creswell (2013), novas formas de se obter dados qualitativos vem emergindo com o tempo, mas todas elas podem ser agrupadas em quatro tipos básicos de 
informações: observações (de não-participante a participante), entrevistas (de roteiros fechados a totalmente abertos), documentos (de privados a públicos) e materiais audiovisuais (incluindo fotografias, vídeos, CDs etc).

Já Yin (1994) apresenta seis principais fontes de evidências que podem ser utilizadas no processo de pesquisa, sendo que todas podem ser inclusas num dos quatro grupos proposto por John W. Creswell (2013):

- Documentação: correspondências, relatórios de eventos, documentos administrativos, estudos ou avaliações formais da empresa, jornais ou outras publicações;

- Registros em arquivo: listas de nomes ou outros itens, mapas, tabelas, dados de levantamentos, registros pessoais etc;

- Entrevistas: podem ser feitas de forma espontânea; ou focal, em que a entrevista é feita por um curto período de tempo, de maneira informal; ou ainda na forma de um levantamento formal;

- Observação direta: no momento da visita de campo ao local do estudo de caso;

- Observação participante: modalidade em que o pesquisador pode assumir diferentes funções dentro do estudo de caso;

- Artefatos físicos: alguma evidência física que se pode coletar ou observar como parte de uma visita de campo e utilizar na pesquisa.

Para o presente trabalho as fontes de dados utilizadas estão detalhadas na Tabela 14, sendo que o uso destas diversas fontes possibilitou a realização de triangulação dos dados, por meio da comparação entre as mesmas, com objetivo de garantir consistência e coerência nos resultados alcançados. 
Tabela 14 - Fontes de dados da presente pesquisa

\begin{tabular}{|c|c|c|c|}
\hline $\begin{array}{l}\text { Fonte de } \\
\text { dados }\end{array}$ & Descrição & Coleta & Papel no estudo \\
\hline $\begin{array}{l}\text { Documentos } \\
\text { públicos }\end{array}$ & $\begin{array}{l}\text { Websites, notas de } \\
\text { imprensa, reportagens, } \\
\text { relatórios anuais, } \\
\text { materiais de } \\
\text { divulgação }\end{array}$ & $\begin{array}{l}\text { Abril de } 2016 \text { a } \\
\text { Janeiro de } 2017\end{array}$ & $\begin{array}{l}\text { Os documentos públicos serviram para avaliar como } \\
\text { as instituições pesquisadas se apresentam ao } \\
\text { mercado em relação ao tema, por meio da } \\
\text { comunicação de suas ações, relatórios e } \\
\text { comunicados em geral. }\end{array}$ \\
\hline $\begin{array}{l}\text { Artefatos } \\
\text { físicos }\end{array}$ & Produtos & $\begin{array}{l}\text { Abril de } 2016 \text { a } \\
\text { Janeiro de } 2017\end{array}$ & $\begin{array}{l}\text { Os produtos serviram para que fossem avaliadas as } \\
\text { aplicações das diversas certificações em suas } \\
\text { embalagens, além de fonte para realizar o } \\
\text { levantamento dos selos existentes no Brasil. }\end{array}$ \\
\hline $\begin{array}{l}\text { Entrevistas } \\
\text { com empresas } \\
\text { B2C }\end{array}$ & $\begin{array}{l}\text { Entrevistas com } \\
\text { executivos de } \\
\text { empresas de bens de } \\
\text { consumo (com e sem } \\
\text { certificação) }\end{array}$ & $\begin{array}{l}\text { Julho a Agosto } \\
\text { de } 2016\end{array}$ & $\begin{array}{l}\text { As entrevistas com representantes de empresas de } \\
\text { bens de consumo serviram para se levantar opiniões } \\
\text { em relação às certificações e o processo de adoção } \\
\text { das mesmas (motivações para utilização ou não, } \\
\text { avaliação das alternativas existentes, análise da } \\
\text { demanda por parte dos consumidores, barreiras } \\
\text { encontradas e formas de superá-las etc). }\end{array}$ \\
\hline $\begin{array}{l}\text { Entrevistas } \\
\text { com empresas } \\
\text { B2B }\end{array}$ & $\begin{array}{l}\text { Entrevistas com } \\
\text { executivos de } \\
\text { empresas fornecedoras } \\
\text { de insumos para } \\
\text { empresas de bens de } \\
\text { consumo }\end{array}$ & $\begin{array}{l}\text { Julho a Agosto } \\
\text { de } 2016\end{array}$ & $\begin{array}{l}\text { As entrevistas com representantes de empresas } \\
\text { fornecedoras de insumos certificados serviram para } \\
\text { se levantar opiniões em relação às certificações e e o } \\
\text { processo de adoção das mesmas (motivações para } \\
\text { utilização ou não, avaliação das alternativas } \\
\text { existentes, análise da demanda por parte dos seus } \\
\text { clientes industriais, barreiras encontradas e formas } \\
\text { de superá-las etc). }\end{array}$ \\
\hline $\begin{array}{l}\text { Entrevistas } \\
\text { com } \\
\text { certificadoras }\end{array}$ & $\begin{array}{l}\text { Entrevistas com } \\
\text { executivos das } \\
\text { certificadoras e } \\
\text { padronizadoras }\end{array}$ & $\begin{array}{l}\text { Julho a Agosto } \\
\text { de } 2016\end{array}$ & $\begin{array}{l}\text { As entrevistas com as certificadoras/padronizadoras } \\
\text { tiveram como objetivo levantar um status desse } \\
\text { mercado no Brasil: legislação, utilização por parte de } \\
\text { empresas e consumidores, principais barreiras para } \\
\text { ampliação do uso, relação com demais stakeholders, } \\
\text { ferramentas do sistema de marketing vigentes nas } \\
\text { organizações, visão de futuro etc. }\end{array}$ \\
\hline
\end{tabular}

Fonte: elaborado pela autora.

Segundo Eisenhardt e Graebner (2007), na medida em que as pesquisas incorporam mais casos e passam a ter foco em fenômenos mais intermitentes e estratégicos, as entrevistas frequentemente se tornam a fonte primária de dados. Segundo as autoras, as entrevistas são uma maneira muito eficiente de coletar dados empíricos de qualidade, especialmente quando o fenômeno de interesse é infrequente. Para Patton (2002), as entrevistas qualitativas são utilizadas para se obter dos entrevistados dados que não são passíveis de observação - como pensamentos, intenções ou comportamentos que ocorreram em determinado período de tempo. O autor ressalta que a qualidade da informação obtida durante uma entrevista depende 
muito do entrevistador e, por isso, ele apresenta formas de se preparar para tal tarefa, assim como outros autores (Creswell, 2013; Mason, 2002).

Entre as primeiras etapas de planejamento está a definição do tipo de entrevista qualitativa que será realizada, para a qual Patton (2002) sugere que existem três abordagens principais: i) conversa informal: oferece máxima flexibilidade para se obter informações em qualquer direção que pareça apropriada; as questões emergem no contexto e são realizadas durante o curso da conversa; ii) guia de entrevista: os tópicos a serem estudados são determinados previamente num formulário, sendo que o pesquisador decide a sequência e a forma de fazer as perguntas durante a entrevista; e iii) entrevista aberta padronizada: as questões e formas de realizar as perguntas são determinadas previamente; a todos os entrevistados são feitas as mesmas perguntas, na mesma ordem. Vale ressaltar que existem outros termos relacionados às abordagens anteriormente descritas, dentre os quais pode-se citar os listados por Selltiz, Wrightsman e Cook (1987): entrevistas não estruturadas (conversa informal), estruturadas (entrevista padronizada) e parcialmente estruturadas (guia de entrevista).

Para Marconi e Lakatos (2005), a entrevista estruturada é utilizada para obter respostas às mesmas perguntas, permitindo assim sua posterior comparação. Já a entrevista nãoestruturada permite explorar mais amplamente uma questão. Patton (2002) vai na mesma linha, e apresenta seus pontos negativos e positivos de cada abordagem. Ao avaliar o que foi descrito pelo autor, optou-se por desenvolver um roteiro de entrevista padronizado, que facilita a comparação das respostas obtidas pelos diversos entrevistados, que respondem a todas as perguntas estabelecidas, além de facilitar também a organização e análise dos dados. Um outro ponto positivo levantado refere-se ao fato de que possíveis avaliadores da qualidade do trabalho possam ver e revisar o roteiro pré-determinado. Os roteiros utilizados na presente pesquisa estão disponibilizados nos apêndices de D a I e eram diferenciados de acordo com o tipo de stakeholder: empresa de bens de consumo (que adotam e não adotam certificações sustentáveis em suas embalagens), empresa fornecedora industrial, certificadora e padronizadora.

O roteiro preparado contou com três blocos semelhantes de perguntas a serem feitas a todos os entrevistados: o primeiro bloco contava com uma caracterização do entrevistado, que se faz importante também para estabelecer empatia e para auxiliar posteriormente na análise de dados. O segundo bloco era uma caracterização da instituição e seu ambiente de negócios - 
principal atuação, missão, número de funcionários e concorrentes, dentre outras questões. Neste caso, era feita uma pesquisa prévia pela pesquisadora com dados secundários oriundos de documentos públicos e de artefatos físicos, sendo que os dados eram validados pessoalmente no dia da entrevista ou posteriormente, via correio eletrônico. O terceiro bloco visava obter dos entrevistados uma opinião geral sobre certificações sustentáveis, seus objetivos e abrangência. Os blocos seguintes estavam relacionados à adesão ou não das certificações específicas que são foco de estudo do presente trabalho por parte das empresas (tanto de bens de consumo com fornecedoras) e, no caso das certificadoras e padronizadoras, de uma auto avaliação em relação às principais barreiras para adesão de suas certificações, sua relação com stakeholders, seu processo de trabalho. No caso das empresas que adotam a certificações, buscou-se compreender como foi o processo, quais as áreas envolvidas, as principais barreiras encontradas e as formas de superá-las, além de um planejamento de longo prazo em relação ao tema. Já com as empresas que não adotam buscou-se compreender as barreiras que impediam o processo e como se daria o processo de adesão, caso acontecesse. Vale ressaltar que as barreiras apresentadas na revisão bibliográfica não foram apresentadas aos entrevistados, pois o objetivo era avaliar se as mesmas surgiam espontaneamente no decorrer da entrevista.

As entrevistas foram realizadas pela própria pesquisadora entre junho e agosto de 2016, e tiveram duração aproximada de 60 minutos, sendo que a mais curta durou 35 minutos e a mais longa durou 93 minutos. Todas foram gravadas e transcritas, para posterior análise dos dados. Note-se que o objetivo do estudo foi revelado aos respondentes já no primeiro contato realizado e, novamente, na introdução da conversa, na qual também era apresentado um termo de consentimento informado (vide apêndice C) que, segundo Creswell (2013), ajuda a estabelecer confiança e empatia. Após a finalização da presente pesquisa, o relatório final foi enviado para todos os respondentes, a fim de que conhecessem os resultados e validassem os dados apresentados. Mais informações sobre os respondentes serão apresentadas no próximo tópico.

\subsubsection{Seleção de empresas/profissionais a serem entrevistados}

Ao definir que serão realizadas entrevistas se faz necessário, então, escolher as empresas que participarão do estudo e as pessoas que serão entrevistadas, que devem ter o tipo de 
conhecimento, experiência ou informações que o pesquisador está buscando. O número de entrevistas pode variar muito, dependendo da natureza da questão de pesquisa, o acesso às pessoas selecionadas, o tempo e orçamento disponíveis, entre outros (Hesse-Biber \& Leavy, 2011).

Eisenhardt e Graebner (2007) citam que a melhor maneira de se obter dados de maior qualidade por meio de entrevistas é pelo uso de abordagens que limitam viés. Para as autoras uma solução ótima é usar diversos informantes que tenham vasta experiência e que vejam o fenômeno estudado de diversas perspectivas. Entre os exemplos citados por Eisenhardt e Graebner (2007) estão atores organizacionais de diferentes níveis hierárquicos, áreas funcionais, localizações, assim como de outras organizações relevantes, dentre outros.

Com esta proposição em mente iniciou-se, então, o processo de escolha das empresas participantes, que deveriam produzir bens de consumo que continham em seu portfólio produtos com embalagens plásticas e/ou de papel - ou seja, embalagens passíveis de conterem a certificação I'm Green e FSC. Estes eram os critérios pré-definidos, ressaltando-se que não havia a preocupação de aleatoriedade. Uma segunda definição esteve relacionada ao o perfil ideal de respondente, para o qual determinou-se que deveria estar relacionado a sua experiência profissional e poder de decisão - todos deveriam ter pelo menos o nível de coordenação, exercendo influência na tomada de decisões por parte da organização. Avaliando as áreas funcionais às quais deveriam pertencer, procurou-se levantar aquelas que tenham alguma relação com as definições de sustentabilidade, certificações e/ou de produtos e, com isso, chegou-se às seguintes áreas: marketing de produtos e/ou desenvolvimento de projetos de produtos, suprimentos (compras), pesquisa e desenvolvimento - foco em embalagens, sistemas de gestão e/ou qualidade e sustentabilidade. No caso das certificadoras e padronizadoras, buscou-se contato com os responsáveis pelas organizações e/ou profissionais envolvidos com o processo específico de certificação de empresas.

Ressalta-se que uma das características pretendidas da amostra leva em conta a técnica intencional de máxima variação citada por Miles e Huberman (1984), que envolve a busca por casos atípicos com objetivo de verificar se os padrões, se houver, continuam existindo. Os autores também comentam sobre a amostragem dentro de cada caso, que seria "iterativa" - ou seja, trabalha-se em "ondas progressivas" a medida que o estudo vai progredindo; e sobre o papel do pesquisador, que assemelha-se ao de um detetive, ao observar, conversar com 
pessoas e colher artefatos e documentos, levando a novas amostras de informantes e observações, novos documentos.

Definidos o tipo de profissional e as empresas desejadas, iniciou-se então os contatos com antigos colegas de trabalho da pesquisadora que, ou já estavam do dentro do perfil desejado, ou indicavam outras pessoas - com perfis semelhantes e/ou contrastantes, conforme mencionado por Miles e Huberman (1984) e Eisenhardt e Graebner (2007) (o conteúdo básico das mensagens eletrônicas que eram enviadas pode ser visualizado no apêndice B). Outras fontes de busca foram os sites das empresas, pelo qual eram enviadas solicitações de contatos, e o site de networking profissional chamado Linked-In, pelo qual a autora buscava contatos nas empresas alvo. Note-se que a mesma técnica foi utilizada por Bhaskaran et al. (2006), em seu estudo sobre as certificações sustentáveis aplicadas em produtos alimentícios em uma cidade da Austrália. Os autores buscaram uma ampla variação no perfil dos entrevistados, que deviam representar elementos diferentes da cadeia de valor e deveria conter tanto empresas grandes quanto empresas pequenas, sendo a característica comum o fato de serem atuantes da indústria de alimentos da região pesquisada.

O mesmo foi feito no processo de busca do presente trabalho. Conforme já mencionado, as unidades de análise eram os diferentes tipos de stakeholders, atuantes na cadeia de valor das empresas de bens de consumo. Buscou-se profissionais de diferentes áreas funcionais e empresas de diversos tamanhos, que adotavam ou não as certificações. Ao final, chegou-se à composição de empresas apresentada na Tabela 15 , sendo que praticamente todas, exceto duas, concordaram em divulgar seus dados. A empresas que não concordaram serão denominadas como Empresa X e Empresa Y. 
Tabela 15 - Caracterização das empresas participantes do estudo

\begin{tabular}{|c|c|c|c|c|c|}
\hline Stakeholder & Organização & Origem & Segmento de atuação & $\begin{array}{l}\text { Número de } \\
\text { funcionários }\end{array}$ & $\begin{array}{l}\text { Tem política de } \\
\text { sustentabilidade? }\end{array}$ \\
\hline \multirow{2}{*}{$\begin{array}{l}\text { Certificadoras / } \\
\text { Padronizadoras }\end{array}$} & FSC Brasil & México & Certificação florestal & 9 & - \\
\hline & Imaflora & Brasil & Sistema de certificação & 68 & - \\
\hline \multirow{7}{*}{$\begin{array}{l}\text { Empresas de } \\
\text { bens de consumo }\end{array}$} & Flape & Brasil & $\begin{array}{l}\text { Móveis tubulares de aço pra } \\
\text { residências }\end{array}$ & 20 & Não \\
\hline & Natura & Brasil & Higiene e beleza & 5.200 & Sim \\
\hline & Empresa Y & EUA & Alimentação & 2.000 & Sim \\
\hline & Kimberly-Clark & EUA & Higiene e bem estar & 6.400 & Sim \\
\hline & L'Occitane & França & Higiene e beleza & $\mathrm{n} / \mathrm{i}^{10}$ & Sim \\
\hline & \begin{tabular}{|l} 
Johnson \& \\
Johnson \\
\end{tabular} & EUA & Saúde e bem estar & 5.000 & Sim \\
\hline & Empresa X & Brasil & Farma e consumo & 13.000 & Não \\
\hline \multirow{4}{*}{$\begin{array}{l}\text { Fornecedores } \\
\text { industriais (B2B) }\end{array}$} & Box Print & Brasil & $\begin{array}{l}\text { Mercado gráfico - embalagens e } \\
\text { displays }\end{array}$ & 420 & Sim \\
\hline & Igaratiba & Brasil & Embalagens plásticas & 650 & Sim \\
\hline & Braskem & Brasil & Setor químico e petroquímico & 8.000 & Sim \\
\hline & Mazurky & Brasil & $\begin{array}{l}\text { Mercado gráfico - embalagens e } \\
\text { caixas de papelão ondulado }\end{array}$ & 45 & Sim \\
\hline
\end{tabular}

Fonte: elaborado pela autora.

Ressalta-se que no caso da Natura foi possível entrevistar duas gerentes da área de embalagens que estiveram diretamente envolvidas com a implementação das duas certificações. Já no caso do FSC, obteve-se contato com a ex-diretora executiva, que deixou o cargo em dezembro de 2015, e também com a atual diretora executiva. Com isso, chega-se ao número de 15 entrevistas no total, conforme listado na Tabela 16:

Tabela 16 - Número de entrevistas realizadas

\begin{tabular}{l|l} 
Stakeholder & Quantidade de entrevistas \\
\hline $\begin{array}{l}\text { Organizações certificadoras e/ou } \\
\text { padronizadoras }\end{array}$ & $\begin{array}{l}\text { 2 de padronizadoras (FSC) } \\
1 \text { de certificadora (Imaflora) }\end{array}$ \\
\hline Empresas de bens de consumo (B2C) & $\begin{array}{l}\text { 8 de empresas (2 da Natura, 1 da Empresa Y, L Occitane, Johnson \& } \\
\text { Johnson, Kimberly-Clark, Flape, Empresa X) }\end{array}$ \\
\hline Fornecedores industriais (B2B) & $\begin{array}{l}\text { 3 de convertedores de embalagens certificadas (Mazurky, Box Print } \\
\text { e Igaratiba) } \\
1 \text { de fornecedor de insumo certificado (Braskem) }\end{array}$ \\
\hline Total & $\mathbf{1 5}$ entrevistas \\
\hline
\end{tabular}

Fonte: elaborado pela autora.

\footnotetext{
${ }^{10}$ Número não informado.
} 
Na Tabela 17 são registrados os nomes, cargos e organizações de todos os respondentes participantes da pesquisa:

Tabela 17 - Caracterização dos entrevistados

\begin{tabular}{|c|c|c|c|}
\hline Stakeholder & Entrevistado & Organização & Cargo \\
\hline \multirow{3}{*}{$\begin{array}{l}\text { Certificadoras / } \\
\text { Padronizadoras }\end{array}$} & Aline Tristão Bernardes & FSC Brasil & Diretora Executiva \\
\hline & Fabiola Zerbini & FSC Brasil & Ex-Diretora Executiva \\
\hline & Daniele Rua & Imaflora & Coordenadora de Certificação Florestal \\
\hline \multirow{8}{*}{$\begin{array}{l}\text { Empresas de } \\
\text { bens de consumo } \\
\text { (B2C) }\end{array}$} & Pedro Dameto & Flape & Diretor Executivo \\
\hline & Flavia Bartholomeu & Natura & Gerente de Transferência de Tecn. e Produtividade $^{11}$ \\
\hline & Raquel Badia & Natura & Gerente de Design \\
\hline & Entrevistado Y & \begin{tabular}{|l|} 
Empresa Y \\
\end{tabular} & Líder de Categoria (Marketing) \\
\hline & AlfredoBaumbach & Kimberly-Clark & Gerente de Projetos (Novos Produtos) \\
\hline & Edson Futino & L'Occitane & Gerente de Desenvolvimento de Embalagens \\
\hline & Carlos Lopes & Johnson \& Johnson & Diretor de Embalagens \\
\hline & Entrevistado $\mathrm{X}$ & Empresa $\mathrm{X}$ & Gerente Sênior de Produtos \\
\hline \multirow{4}{*}{$\begin{array}{l}\text { Fornecedores } \\
\text { industriais (B2B) }\end{array}$} & Luis Martini & Box Print & Coordenador de Sistema de Gestão \\
\hline & Claudia Cappra & Braskem & Diretora Comercial \\
\hline & Paulo Toledo & Igaratiba & Supervisor de Desenvolvimento \\
\hline & Elaine Cristina & Mazurky & Coordenadora Administrativa \\
\hline
\end{tabular}

Fonte: elaborado pela autora.

Outro ponto importante está relacionado ao fato de que todas as empresas entrevistadas eram passíveis de conterem as duas certificações em pelo menos uma de suas embalagens. Com isso, buscou-se avaliar o conhecimento dos profissionais sobre ambas, mesmo que a empresa só adotasse uma delas. Uma segunda consideração relevante é referente ao fato de que, em algumas empresas, faz-se uso do insumo certificado, mas não da respectiva comunicação aplicada na embalagem. Os motivos para tal comportamento serão debatidos na análise dos dados. A composição final dos casos analisados da certificação FSC é apresentada na Tabela 18:

\footnotetext{
${ }^{11}$ A profissional era da área de Desenvolvimento de Embalagens quando da implementação do plástico verde, da Braskem, na primeira linha de protdutos da Natura.
} 
Tabela 18 - Consolidado de empresas - caso FSC e "I'm Green"

\begin{tabular}{l|l|l}
\hline FSC & B2C & B2B \\
\hline \multirow{5}{*}{ Adota o selo } & Natura & \\
Kimberly Clark & Box Print \\
& $\begin{array}{l}\text { L'Occitane } \\
\text { Johnson \& Johnson } \\
\text { Empresa Y }\end{array}$ & Mazurky \\
\hline Não adota o selo & $\begin{array}{l}\text { Empresa X } \\
\text { Flape }\end{array}$ & n/a \\
\hline
\end{tabular}

Fonte: elaborado pela autora.

Na Tabela 19 é apresentada a composição final dos utilizados referentes à certificação "I'm Green":

Tabela 19 - Consolidado de empresas - caso I'm Green

\begin{tabular}{l|l|l}
\hline I'm Green & B2C & B2B \\
\hline \multirow{3}{*}{ Adota o selo } & $\begin{array}{l}\text { Natura } \\
\text { Kimberly Clark } \\
\text { L'Occitane } \\
\text { Johnson \& Johnson }\end{array}$ & Igaratiba \\
\hline Não adota o selo & $\begin{array}{l}\text { Empresa X } \\
\text { Flape } \\
\text { Empresa Y }\end{array}$ & $\mathrm{n} / \mathrm{a}$ \\
\hline
\end{tabular}

Fonte: elaborado pela autora.

Faz-se importante ressaltar que a amostra escolhida para a presente pesquisa é não probabilística, intencional e por conveniência, o que implica que os seus resultados não poderão ser generalizados para o universo dos stakeholders envolvidos no processo de certificação sustentável. Portanto, não se buscará a generalização estatística, mas tão somente a generalização analítica (fortalecimento de teorias emergentes sobre o tema).

Por último, registra-se que, segundo Berg (2004), a entrevista por telefone não é a maneira mais indicada para se obter dados qualitativos, mas que, sob certas circunstâncias, podem prover um meio - talvez o único, de se obter os dados que se busca, principalmente quando relacionado a questões de localização geográfica. $\mathrm{O}$ autor comenta que o principal fator que prejudica a qualidade deste tipo de entrevista é o fato de não poder observar a comunicação não-verbal dos entrevistados, o que é corroborado por Creswell (2013). Ressalta-se que, devido a restrições orçamentárias, e ao fato de o Brasil possuir dimensões continentais, foi 
possível realizar somente oito entrevistas pessoalmente, sendo que as sete restantes foram realizadas por telefone e/ou Skype.

\subsection{Tratamento e análise dos dados}

Para Hesse-Biber e Leavy (2011) a análise qualitativa de dados é um processo iterativo de coleta juntamente com a análise, sendo que os dois praticamente acontecem de forma simultânea. Os autores ressaltam que é importante registrar as impressões gerais e ideias que surgiram da entrevista logo após seu acontecimento. A preparação dos dados da presente pesquisa começou a ser feita pela autora após cada entrevista, ao tomar nota dos fatores considerados mais relevantes que foram citados pelos entrevistados. A transcrição das entrevistas foi realizada por uma profissional contratada a fim de agilizar o processo de tratamento e análise de dados. Após recebimento do arquivo com cada transcrição era feita uma validação do mesmo para checar sua veracidade e também para elucidar as dúvidas existentes.

A análise foi realizada com base na análise de conteúdo das respostas às entrevistas em profundidade. Segundo Bardin (1977), esse tipo de análise é "um conjunto de técnicas de análise das comunicações visando obter, por meio de procedimentos sistemáticos e objetivos de descrição do conteúdo das mensagens, indicadores que permitam a inferência de conhecimentos relativos às condições de produção/recepção destas mensagens" (p.31). Para apoiar este processo, foram utilizados o software Atlas/ti, que foi desenvolvido com o objetivo de oferecer uma ferramenta de análise de dados para auxiliar pesquisadores (Bandeira-de-Mello, 2010) e o editor de planilhas Excel, da Microsoft.

Para realizar a apresentação dos resultados, seguiu-se a proposta de Eisenhardt e Graebner (2007), para quem a construção de teoria com o uso de casos múltiplos deve ser feita em seções ou por proposições distintas, de maneira que se consiga dar suporte por meio de evidências empíricas (como citações, por exemplo), e contando com o apoio de tabelas e outros recursos visuais que resumam o conteúdo que está sendo transmitido. Após leitura das entrevistas iniciou-se o processo de tabulação das respostas. A codificação foi realizada tomando-se como base os principais constructos utilizados no roteiro de entrevistas, mas com flexibilidade para a criação de novos constructos no decorrer da avaliação. Ao final deste 
processo, considerou-se, então, os seguintes constructos que serão o fio condutor de toda a análise de dados de cada caso:

- Contato inicial com a certificação e motivações para adoção;

- Processo de implementação: áreas envolvidas, prazo para lançamento, recursos investidos, retorno do investimento, negociação com fornecedores;

- Diferenciais e/ou impactos que a certificação oferece ao negócio;

- Barreiras à implementação das certificações.

Vale ressaltar que o último constructo - barreiras - é o principal, e foi deixado por último pelo fato de sofrer influência de todos os demais. Ou seja, o processo de implementação foi detalhado em seus principais aspectos, desde os motivadores até a sua execução, com o objetivo de, ao final, levantar e classificar todas as barreiras que foram citadas - tanto diretamente, quanto implicitamente, nas respostas às demais perguntas. Após a apresentação de cada caso específico, foi feita um comparativo entre as barreiras encontradas nos mesmos e procedeu-se a sua classificação de acordo com o estudo sobre barreiras à gestão da cadeia de suprimentos sustentáveis (GCSS) de Walker e Jones (2012) (vide tópico 2.2.2), que foi escolhido pelo fato de não ter focado nenhuma indústria especifica do país em questão (Reino Unido), e também pelo seu objetivo, que era avaliar o ponto de vista de stakeholders do processo, assim como o presente trabalho. Outras barreiras que surgiram nas entrevistas também foram descritas e classificadas. Por fim, classificou-se as barreiras que haviam sido levantadas na revisão bibliográfica, e procedeu-se a consolidação de uma listagem única de barreiras à adoção de certificações sustentáveis por parte das empresas; foi desenvolvido um mapeamento que possibilita visualizar como as barreiras atuam na relação entre os stakeholders envolvidos no processo de certificação e feita a proposta de classificação das barreiras às certificações sustentáveis. No tópico a seguir serão apresentados os resultados da presente pesquisa. 


\section{RESULTADOS}

A análise dos dados será apresentada conforme indicado por Yin (1994): primeiro serão relatados os casos FSC e I'm Green isoladamente, com posterior cruzamento dos dados a fim de se buscar padrões e/ou contrastes existentes entre os mesmos. Para cada caso serão apresentados o histórico e as características principais das certificações, e depois será feita a apresentação das informações relacionadas a cada constructo para, ao final, classificar e discutir as barreiras levantadas. Por fim serão relatadas as barreiras que surgiram nas entrevistas sem estar relacionadas a nenhum dos casos, e será feita uma apresentação das possíveis formas citadas pelos entrevistados de se superar estes obstáculos.

\subsection{Caso 1 - FSC}

O Forest Stewardship Council (FSC) foi formalmente estabelecido em 1994, fruto de um trabalho iniciado em 1990 por diversos representantes de grupos empresariais, sociais e de organizações ambientais que tinham a finalidade de melhorar o manejo florestal ao redor do mundo. No Brasil, um grupo de trabalho articulava as decisões em torno do FSC desde 1996, sendo esta iniciativa formalizada em 2001, sob o nome de "Conselho Brasileiro de Manejo Florestal - FSC Brasil” (Forest Stewardship Council, 2012).

A missão do FSC é promover uma gestão ambientalmente adequada, socialmente benéfica e economicamente viável das florestas mundiais (Forest Stewardship Council, 2016a). Isto se dá por meio da certificação: um sistema de garantia internacionalmente reconhecido, que identifica, por meio de sua logomarca, produtos madeireiros e não madeireiros originados do bom manejo florestal. Todo empreendimento ligado a operações de manejo florestal e/ou à cadeia produtiva de produtos florestais pode obter a certificação FSC, que é um processo voluntário em que a certificadora realiza uma avaliação de um empreendimento florestal e verifica os cumprimentos de questões ambientais, econômicas e sociais que fazem parte dos princípios e critérios da organização (Forest Stewardship Council, 2016b). O FSC oferece três modalidades de certificação: 
- Manejo Florestal: garante que a floresta é manejada de forma responsável, de acordo com os princípios e critérios da certificação FSC, e pode ser obtido por todos os produtores, sejam pequenas, grandes operações ou associações comunitárias. As florestas podem ser naturais ou plantadas, públicas ou privadas, e a certificação pode ser caracterizada por tipo de produto - madeireiros, como toras ou pranchas; ou não madeireiros, como óleos, sementes e castanhas;

- Cadeia de custódia (CoC): garante a rastreabilidade desde a produção da matéria-prima que sai das florestas até chegar ao consumidor final, e aplica-se aos produtores que processam a matéria prima de florestas certificadas - serrarias, fabricantes, designers e gráficas;

- Madeira controlada: tem como objetivo orientar as empresas certificadas a evitarem produtos com origem florestal de categorias consideradas inaceitáveis (procedentes de atividades florestais social e ambientalmente danosas) pelo FSC, sendo que a partir desta avaliação, as empresas controlam a origem dos materiais usados para a composição dos produtos "FSC Misto" (Forest Stewardship Council, 2016b).

Hoje, o FSC é a única organização reconhecida internacionalmente, dedicada ao desenvolvimento de padrões para o manejo florestal responsável, que tem o apoio tanto do setor empresarial como de organizações ambientalistas e grupos sociais (Forest Stewardship Council, 2012). Uma das razões para que isso aconteça está relacionada ao fato de contar com uma gestão multi-stakeholder, ou seja, é uma associação civil governada por seus membros, que podem ser individuais (pessoa física) ou organizacionais (pessoa jurídica), e com origens diversas, desde representantes de ONGs ambientais e sociais e comerciantes de madeira, até pequenos produtores, grupos comunitários e fabricantes e varejistas, dentre outros. Estes membros são divididos em três câmaras: Ambiental, Econômica e Social, sendo que cada câmara possui $33,3 \%$ do peso dos votos, garantindo a equidade entre diferentes grupos de interesse e níveis de poder econômico (Forest Stewardship Council Brasil, 2017).

Diversos estudos já tiveram o FSC como foco, seja para buscar explicações sobre o surgimento e expansão dos sistemas privados de regulamentação (Bartley, 2003), para descrever e analisar o mercado de produtos certificados em determinado país, com foco no desafio de aumentar a sua demanda (Ham, 2007) ou para estimar a demanda de um novo 
projeto que está sendo desenvolvido e testado pelo FSC, envolvendo a oferta de serviços de ecossistemas florestais (Jaung, Putzel, Bull, Guariguata, \& Sumaila, 2016).

No estudo de Nebel et al.(2005) sobre empreendedores que trabalham com florestas na Bolívia, foi levantado que a certificação FSC proporcionou poucas melhorias práticas em relação à qualidade do manejo florestal, pois as questões regulatórias já são bem exigentes no país e, em sua maioria, já contemplam também os requisitos do FSC. Os autores concluem que a certificação FSC na Bolívia tem sido utilizada com foco em demandas de mercado (principalmente no que se refere a exportação e ao estabelecimento de preços mais altos), ao cumprimento da legislação vigente, e ao estabelecimento de um fórum de discussão sobre temas relacionados com diversos atores envolvidos na área.

Alguns estudos também buscaram avaliar o real impacto da certificação FSC na proteção das florestas (Guéneau \& Carneiro, 2016) ou até criticavam a forma de atuação da organização, mostrando sérias falhas nas certificações que estavam sendo feitas em seu nome e afirmando não ser possível assegurar que produtos contendo o logo da FSC realmente eram oriundos de florestas bem manejadas (Counsell \& Loraas, 2002). Conclui-se que o sistema FSC tem uma ampla atuação em diversos países, tendo sido objeto de diversos estudos sobre os mais variados tópicos, sendo que nenhum teve como objetivo específico compreender as barreiras para sua implementação por parte de empresas de bens de consumo.

A seguir serão apresentados os resultados da presente pesquisa. Ressalta-se que foi possível mapear o processo inteiro de implementação, desde o seu início, em três casos, nos quais obteve-se acesso a profissionais que participaram dos respectivos projetos - Natura, Mazurky e Box Print. Os demais entrevistados não tiveram envolvimento direto na implementação da certificação em seu portfolio de produtos, e somente tinham algum conhecimento do histórico e da aplicação atual da certificação.

\subsubsection{Contato inicial e motivações}

De forma geral, não foi possível encontrar um padrão em relação a como as empresas tomam conhecimento da certificação FSC e porque a adotam. Das três empresas nas quais foi possível mapear todo o processo, somente a Natura estava ativamente em busca de uma 
alternativa sustentável de cartucho ${ }^{12}$ para uma de suas linhas de produtos. Segundo a gerente de Design Raquel Badia, em 2005 a empresa tinha acabado de desenvolver um cartucho com papel reciclado para uma linha com apelo sustentável (linha Natura Ekos) e, com isso, surgiu um questionamento da própria equipe em relação a critérios de sustentabilidade utilizados em cartuchos de outras linhas de produtos:

[...] estávamos sendo contraditórios, pois trabalhávamos com cartão $100 \%$ reciclado pósconsumo para a linha Ekos, que é muito legal, mas a linha Chronos, que é super premium, não combina com um cartão tão rústico e então ficamos sem um apelo ambiental para ela. Então a gente começou a pesquisar o que poderia falar de um cartão $100 \%$ virgem, um cartão mais premium. (Raquel Badia, Natura)

Com isso em mente, numa conversa entre o diretor da área de embalagens da Natura com um executivo da Klabin, fornecedor de papel, a ideia de obter a certificação para uma linha de papéis deste fornecedor surgiu de forma espontânea:

[...] em conversa informal, o nosso diretor comentou com a Klabin que a gente estava procurando uma outra proposta pra um cartão totalmente virgem, e a Klabin comentou que havia a possibilidade de certificar o cartão, uma vez que a madeira vendida por eles para o mercado moveleiro já era certificada. E assim criamos um grupo de trabalho para fazermos isso juntos. (Raquel Badia, Natura)

Já a Box Print tomou conhecimento da certificação por meio da própria Natura, sua cliente, que envolveu a empresa no projeto para desenvolver o cartucho acima mencionado. No caso da Mazurky, a certificação ficou sendo conhecida por meio da interação e o estabelecimento de uma parceria, e 2016, com a Formag's, uma empresa gráfica vizinha à sua fábrica, que havia obtido a certificação FSC em 2010. Note-se que se tratam de duas empresas gráficas brasileiras que desconheciam a certificação FSC, que é altamente relacionada com este tipo de negócio, dado que a origem de sua matéria prima principal (papel) é de madeira. Tal sorte de desconhecimento é reconhecida pela organização FSC. Em seu planejamento 2015-2020, um dos cinco objetivos estratégicos é "ampliar o reconhecimento da marca e do conceito FSC, em todos os elos da cadeia produtiva florestal até o consumidor final" (Forest Stewardship Council, 2015). Na entrevista concedida para a presente pesquisa, Aline Bernardes, atual diretora executiva, afirmou:

\footnotetext{
${ }^{12}$ Cartucho é o nome que se dá para a caixa de papel que protege e embala os produtos.
} 
[...] as vezes as empresas, elas exatamente por causa dessa deficiência mesmo que a gente tem em relação a posicionar a marca no mercado, se fazer conhecer, se colocar como opção de escolha, elas acham que não vale a pena; muitas empresas acham que não vale a pena se certificar se o mercado não exige isso [...] (Aline Bernardes, FSC)

Nas demais empresas pesquisadas que adotam a certificação, três o fazem no Brasil atendendo a diretrizes globais estabelecidas por suas matrizes: Empresa Y, L'Occitane e Johnson \& Johnson (J\&J). Edson Futino, da L’Occitane, ressaltou que na Europa, onde fica sua matriz, a certificação pode ser considerada um padrão, sendo que a maioria dos fornecedores já possuem o FSC. Na Kimberly-Clark (KC), a iniciativa surgiu da área de suprimentos: "a área de Supply Chain que trouxe a ideia, em uma reunião do nosso comitê de sustentabilidade, porque já comprávamos parte da celulose certificada FSC e então surgiu a ideia de estender o selo a nossos produtos" (Alfredo Baumbach, KC).

Em relação às duas empresas que não adotam o FSC - Flape e Empresa X, seus entrevistados conhecem a certificação pelo fato de terem trabalhado anteriormente em empresas que adotavam a mesma, e as razões para não adoção são similares: ambas não reconhecem o valor que a certificação poderia trazer para o seu negócio. Na Flape, seu diretor executivo, Pedro Dameto, argumenta que a embalagem não é um fator relevante para seus produtos, dado que geralmente não são expostas ao consumidor final durante o processo de escolha. Na Empresa X, por sua vez, o gerente de produtos entrevistado cogitou usar a certificação em sua linha de produtos, mas não obteve o incentivo e aprovação por parte de seus superiores. Para o profissional, o momento da marca sob sua responsabilidade exigia outros planos de ação mais prioritários do que o envolvimento com temas relacionados à sustentabilidade.

Em relação às motivações para adoção de certificações, de uma maneira geral, pode-se listar três grandes objetivos: alinhamento com estratégia da empresa, atendimento à demanda de clientes e conquista de diferencial competitivo, visando aumentar vendas. Ressalta-se que todas as organizações entrevistadas que adotam a certificação têm uma política de sustentabilidade formalmente estabelecida e/ou algum direcionamento explícito com relação a adoção de ações socioambientais em sua gestão, o que pode sugerir que a certificação seja uma das possíveis ferramentas de promoção da sustentabilidade nas organizações. Segundo 
relatório da UNEP (2015a), o objetivo da certificação na cadeia de suprimentos é garantir credibilidade e a sustentabilidade de suas matérias primas e dos suprimentos que produzem. No caso da Natura, por exemplo, a motivação esteve relacionada ao alinhamento com a estratégia da empresa, que prevê a oferta de "produtos e serviços que promovem, ao mesmo tempo, beleza, prazer e sustentabilidade" (Natura, 2015, p.10). O mesmo pode ser dito em relação às outras empresas (KC, J\&J, Mazurky, Box Print, L’Occitane, Empresa Y), cujas estratégias englobam a preocupação com questões socioambientais na forma de fazer negócios, como pode ser observado nos exemplos a seguir:

[...] na verdade, assim, o conceito de sustentabilidade já está impregnado na empresa desde a sua fundação, em 1958, pelo Sr. Arm Schmidt, que já iniciou com os princípios da compra correta da principal matéria prima que é o cartão, de fontes que fossem corretas. (...) Então isso já vem desde antes, que seria o respeito ao meio ambiente por essa condição de extração dos recursos naturais. (Luiz Carlos Martini, Box Print)

Há tempos a Mazurky é pautada por ações que minimizam impactos e preservam o meio ambiente, como o controle do consumo de tinta, cola e fita de arquear. A empresa ainda mantém uma busca contínua por sistemas que permitam uma maior redução do consumo de insumos, como a energia elétrica. (site da empresa)

A Mazurky foi uma das empresas que alegou o diferencial de mercado como uma das principais motivações para obter a certificação, principalmente no que se refere à credibilidade que essa conquista passa ao mercado, além do alinhamento com a estratégia da empresa, que já possui outras certificações referentes a questões sociais e ambientais. Segundo Elaine Cristina, da Mazurky:

[...] é uma certeza que o cliente tem de que esta é uma empresa que trabalha atendendo toda legislação, e que não vai, de uma hora pra outra, ele chegar aqui bater a porta e falar "a Mazurky não vai me entregar porque fechou as portas". Além disso, temos que renovar sempre todas essas licenças, todas essas documentações [...]

No caso específico da certificação FSC, não foi encontrado um padrão entre as respostas. Para a Natura, argumentou-se a questão do pioneirismo, dado que ela seria a primeira empresa a adotar o selo em produtos de bens de consumo, garantindo a origem do papel utilizado em suas embalagens, sendo este um aspecto muito valorizado internamente naquele momento. Ao determinar que seria esta a certificação, a empresa passou a demanda para a Box Print. A relação entre os stakeholders da cadeia no que se refere ao impacto que um exerce no outro 
quando da adoção das certificações fica evidente na fala de Luiz Martini: “já comprávamos de alguns fornecedores, que então passaram a nos fornecer o papel certificado, e de outros fornecedores posteriormente a gente solicitou, acredito que os demais gráficos do mercado também, e eles foram aos poucos se adequando". Na Natura e na KC, aconteceu o mesmo: "Depois buscamos envolver outros fornecedores (...) e todos eles começaram a buscar essa certificação. A ideia era expandir mesmo" (Raquel Badia, Natura); "Não bastava comprar madeira certificada para produzir a celulose, era preciso envolver ainda mais o fornecedor no processo, fazendo com que se certificasse" (Kimberly-Clark, 2010). Isso está em linha do que foi proposto por Rubik et al. (2008), que mencionam que os fornecedores recebem os requerimentos de seus clientes a fim de preencher os requisitos de uma certificação, e por Seuring e Müller (2008), que mencionam o quanto uma empresa repassa a sua cadeia de fornecedores as pressões recebidas por outros stakeholders em relação a adoção de padrões mais sustentáveis de produção.

A Mazurky, ao tomar conhecimento do FSC, buscou informações no mercado para avaliar a receptividade de seus clientes em relação à certificação e percebeu que havia demanda para produtos certificados. Segundo Elaine, dois de seus clientes já haviam confirmado ter interesse neste tipo de fornecimento. Para a KC foi outro stakeholder que teve influência fundamental na adoção do FSC: a ONG internacional Greenpeace, que começou a fazer campanhas contra a empresa na década de 1990 denunciando práticas de exploração de recursos madeireiros de forma não responsável:

[...] Nós tivemos muitos problemas com o Greenpeace no passado e hoje é um orgulho pra gente falar disso, porque são coisas que foram superadas, e a empresa hoje tem esse aporte de sustentabilidade e dá tanta importância pro FSC, por exemplo, porque realmente entendeu qual era a mensagem, ou porque aquilo que estava fazendo era ruim à sustentabilidade do ambiente e dos negócios [...] Alfredo Baumbach, KC

A relação entre a KC e o Greenpeace, após tantos impasses, acabou gerando uma parceria entre as duas organizações (Gies, 2014). Em seu relatório anual de 2009, por exemplo, a KC noticia um acordo com a ONG a fim de adequar sua política global de compra de insumos, tendo passado a exigir que "toda a celulose que usa mundo afora fosse de origem certificada" (Kimberly-Clark, 2010, p.50). As demais empresas não souberam justificar a escolha pelo FSC, alegando somente a questão de atender a diretrizes internacionais ou o desconhecimento de certificações concorrentes. 
Nota-se claramente que não existe um padrão em relação a que área da empresa seria a maior responsável por determinar a necessidade e/ou desejo de uma certificação sustentável. Nas empresas em que existe uma política de sustentabilidade, supõe-se que tal política tenha sido elaborada e aprovada pela alta direção. Nestes casos, percebe-se que as áreas de pesquisa e desenvolvimento voltados para embalagens, compras e/ou sistemas de gestão (responsáveis por certificações de forma geral) são as principais responsáveis por definir como a política seria revertida em ferramentas práticas para implementação dentro de sua cadeia de suprimentos, a qual está relacionada com a compra de insumos certificados. As áreas de sustentabilidade e/ou de responsabilidade social corporativa, e de marketing, de maneira geral, não foram citadas como demandantes em nenhuma das entrevistas. No caso do marketing, isso pode ser verificado por meio das palavras de Entrevistado Y:

“[...] Não é uma questão de Marketing... lá na Empresa Y não é o Gerente de Marketing que fala 'eu quero ter um selo sustentável no meu produto'. Ou vem uma diretriz de fora falando 'você tem que ter aquele selo', ou é uma coisa que vem muito mais da área de compras mesmo, que vem oferecer novos materiais - sustentáveis ou com qualquer tipo de inovação. Marketing não procura esse tipo de coisa [...]"

Segundo ele, o "logotipo é aplicado somente na caixa de embarque dos produtos, e a gestão disso acaba ficando mais com a área de embalagem do que com a minha, pois é uma coisa que não vai para o consumidor”. Na Tabela 20, procurou-se condensar o conteúdo do presente tópico a fim de facilitar a visualização: principais formas citadas de como profissionais entrevistados passaram a conhecer o FSC, as principais motivações para adotar uma certificação sustentável e as barreiras que foram inferidas deste processo após análise da pesquisadora. 
Tabela 20 - Consolidação: formas de contato, motivações e barreiras levantadas (FSC)

\begin{tabular}{l|l|l}
\hline Como conheceu & Principais motivações & Barreiras levantadas \\
\hline - Busca ativa & $\begin{array}{l}\text { Certificações em geral } \\
\text { - Alinhamento com política de } \\
\text { sustentabilidade (redução de } \\
\text { impacto ambiental) } \\
\text { - Casualmente }\end{array}$ & $\begin{array}{l}\text { - Desconhecimento por parte das } \\
\text { empresas } \\
\text { - Falta de demanda de garantia de } \\
\text { origem por parte de stakeholders } \\
\text { - Falta do cliente política de sustentabilidade }\end{array}$ \\
$\begin{array}{ll}\text { - Diferencial competitivo para } \\
\text { aumentar vendas }\end{array}$ & $\begin{array}{l}\text { por parte das empresas } \\
\text { - Falta de envolvimento e/ou apoio } \\
\text { político e/ou priorização por parte da } \\
\text { alta direção } \\
\text { - Baixo envolvimento da área de } \\
\text { marketing na demanda por } \\
\text { certificações } \\
\text { - Rigidez por parte do FSC (pode } \\
\text { afastar possíveis interessados na } \\
\text { certificação) }\end{array}$ \\
\hline
\end{tabular}

Fonte: elaborado pela autora.

Pode-se verificar um alinhamento dos achados em relação à motivação para adoção das certificações, com as motivações encontradas na literatura para adoção da GCSS. Seuring e Müller (2008), por exemplo, levantaram os seguintes critérios citados em diversos estudos: demandas regulatórias, resposta a stakeholders, (incluindo grupos de pressão ambientais e/ou sociais), vantagem competitiva, demanda de consumidores e/ou clientes, perda de reputação. Note-se que muitos destes critérios também foram citados nos trechos das entrevistas detalhados neste tópico.

Especificamente sobre o FSC encontrou-se o estudo de Pinto e Granja (2013), que citou a exigência dos clientes como principal motivação para as empresas brasileiras estudadas e também a americana, sendo que esta última citou também a intenção de utilizar da certificação como uma ferramenta de marketing. Ham (2007), por sua vez, também avaliou as motivações para adoção de certificação ambiental, mas por empresas na África do Sul, e concluiu que a principal razão também estava relacionada com a demanda dos clientes, compostos em sua maioria por empresas para os quais exportavam os insumos e/ou produtos. Outra motivação citada foi a captura de novos mercados.

Vale retomar o estudo de Overdevest \& Rickenbach (2006), que elencou as três principais motivações relacionadas ao desenvolvimento de políticas de manejo florestal, a 
saber: i) orientação ao mercado; ii) orientação para sinalização; e iii) orientação para aprendizagem. Quando comparadas as motivações citadas pelos entrevistados (consolidadas na Tabela 20) com as categorias propostas pelos autores, conclui-se que, para certificação geral, as motivações estão relacionadas ao mercado, sendo que uma delas ("alinhamento com política de sustentabilidade”) não caberia em nenhum dos tipos citados pelos autores. Já entre o que foi citado especificamente para o FSC, uma está mais relacionado com a sinalização ("influência de stakeholders"), e as outras duas também não caberiam em nenhum tipo citado ("pioneirismo" e "desconhecimento de outras certificações").

Por último, vale citar que tanto Fabíola Zerbini quando Aline Bernardes, antiga e atual diretoras executivas do FSC no Brasil, respectivamente, comentaram que a certificação FSC atende mais a grandes empresas atualmente. Isto está em linha com o estudo de Ham (2007), para quem as pequenas e médias organizações não teriam capacidade administrativa para lidar com as demandas adicionais exigidas pelos padrões estabelecidos, apresentado dificuldades em obter a certificação. Nebel et al. (2005) corroboram com esta questão, e comenta, ainda que a predominância de empresas grandes no esquema acaba por distorcer as condições de produção florestal em nível nacional. Esta barreira poderia estar inserida na que já foi levantada como "Rigidez por parte do FSC".

\subsubsection{Processo de implementação}

Ao contrário do que aconteceu no tópico anterior, nas questões referentes ao processo de implementação da certificação foi possível reconhecer alguns padrões dentre as empresas pesquisadas. Vale relembrar a diferença que existe entre as fornecedoras e as empresas que produzem o bem de consumo final, já mencionada na Tabela 12 (tópico 3.2): para as primeiras, faz-se necessário obter a certificação de cadeia de custódia, e as últimas compram o insumo certificado pronto. No caso da $\mathrm{KC}$, dado que a empresa atua diretamente na produção de bens de consumo que usam a própria celulose com insumo (e não somente o papel certificado na embalagem), também abre-se a possibilidade de certificação da cadeia de custódia. Nestas três empresas (Box Print, Mazurzy e KC), o custo inicial de implementação foi absorvido, assim como os custos anuais de manutenção - ou seja, não houve antes, e nem há atualmente, repasse do investimento aos seus clientes na forma de aumento de preços. Fabíola Zerbini resumiu a questão do aumento de custo relacionado às adaptações internas 
que devem ser feitas pelas empresas, quando necessário, ao qual posteriormente são somados os custos das auditorias. Segundo ela,

[...] o custo da certificação não é só o da certificação, que já pode ser alto, mas não é só isso. O custo da certificação é o custo de internalização de custos sociais e ambientais que outros processos produtivos não internalizam, então, você formalizar todos os seus trabalhadores, comprar EPIs (equipamentos de proteção individual) pra todos, não poluir mais o rio... isso tudo custa. Acho que deveria ser o básico, mas ainda tem uma série de empresas que não fazem.

Apesar disso, todas as empresas afirmaram que o custo da matéria-prima certificada é o mesmo que uma sem certificação. Para a Natura houve troca do tipo de papel que seria utilizado na embalagem do produto, o que acabou impactando o seu custo, mas que, de acordo com Raquel Badia, não foi difícil de aprovar, dado que "aqui (na Natura) a gente paga um pouquinho o pedágio da inovação, né?".

O prazo para se obter a certificação e/ou passar a comprar embalagens com papel certificado foi considerado rápido por todos os entrevistados - entre cinco e dez meses. Box Print e Mazurky mencionaram que o fato de já terem a questão da sustentabilidade incorporada ao negócio facilitou o processo, pois sua produção já levava em consideração questões socioambientais. Ambas as empresas ressaltam a conquista da certificação como um diferencial a ser oferecido aos seus clientes. Um fato levantado por Luis Martini, da Box Print, está relacionado à restrição de mão de obra técnica para realizar as auditorias, pois a demanda ainda é baixa e vem se mantendo assim já há algum tempo. Esta questão foi citada nos relatórios da Iseal Alliance (2010) e SustainAbility (2011) como um problema de escala enfrentado pelas instituições que definem estes padrões. Fabíola Zerbini, do FSC, também mencionou a restrição de capacidade técnica, porém relacionada ao quadro de colaboradores da empresa, dado que há diversas exigências a serem cumpridas para se obter a certificação.

Em relação às áreas envolvidas no processo, as que foram citadas por todos os entrevistados foram: suprimentos e/ou compras, planejamento e produção, projetos e marketing e/ou comercial. No caso das empresas fornecedoras (Mazurky e Box Print), a área que liderou o projeto foi a de sistemas de gestão. Segundo Elaine, da Mazurky, a empresa inteira foi envolvida. Além das áreas já listadas, Elaine citou também os profissionais de faturamento e de transporte, pois, segundo ela, todos tem que saber diferenciar uma carga 
"normal" de uma carga com papel certificado, e também seus diretores, que foram os maiores apoiadores do processo. Elaine ressaltou ainda que ela mesma se dedicou a estudar os padrões estabelecidos pelo FSC, além de contar com o apoio de diversos parceiros. Posteriormente, foram realizados treinamentos com as equipes internas na preparação para a auditoria, sendo que uma das maiores dificuldades do processo foi a própria ansiedade de toda a equipe.

A Natura mencionou as áreas de pesquisa e desenvolvimento, com foco em embalagens, e de novas tecnologias, que foi a área que liderou o projeto. Já a $\mathrm{KC}$ mencionou as áreas de auditoria e meio-ambiente, e ressaltou, em seu Relatório de Sustentabilidade de 2011, o envolvimento de toda a operação da empresa na certificação: "Junto com o treinamento dos funcionários, (a etapa de auditorias internas) foi o grande desafio da onda FSC, que veio para cobrir toda nossa operação, do fornecedor ao centro de distribuição" (Kimberly-Clark, 2011, p.45).

Do ponto de vista do Imaflora, o principal ponto de contato dentro das empresas é a área de qualidade, que cuida das auditorias e certificações. Em alguns casos, segundo Daniela, esses processos podem estar sob responsabilidade dos profissionais de planejamento e produção. Para a coordenadora foi possível notar uma mudança, com o passar do tempo, em como as empresas lidavam com a implementação das certificações: antes negociava-se direto com as pessoas responsáveis pelas funções já mencionadas (qualidade e/ou produção), e atualmente faz-se necessário lidar com a área de suprimentos, que é responsável por negociar os valores envolvidos. Outros envolvidos são as áreas de marketing e/ou comercial, para definir questões de uso da logomarca do FSC, e o jurídico, para definir os termos do contrato de prestação de serviços.

A utilização ou não da logomarca é um ponto a ser ressaltado. Na Natura, por exemplo, uma política interna orienta para a utilização do papel certificado ou reciclado nos cartuchos dos produtos. Quando opta-se pelo FSC, segundo Flavia Bartholomeu,

[...] "há uma diretriz em embalagens que fala para colocar (a certificação) e qual é a regra para colocar, mas aí no fim é no projeto, na hora que a gente está desenhando a arte junto com o marketing, (que a gente avalia) se vai caber (o logotipo), se faz sentido, se não faz, colocar ou não. Não existe uma diretriz da empresa sobre isso - tipo 'tem que por e pronto'” 
Ou seja, há uma questão relacionada com a apresentação da embalagem, em que os responsáveis pelo lançamento do produto devem avaliar aspectos estéticos, e não funcionais. Algumas embalagens de papel avaliadas pela pesquisadora não continham o logotipo do FSC, não sendo possível saber se o motivo era por não ser um papel certificado, mas sim reciclado, ou por decisão própria da empresa de não aplica-lo. A questão de possuir a certificação, mas optar-se por não aplicar o logotipo na embalagem, pode ser considerada uma barreira, dado que perde-se a oportunidade de divulgar o mesmo.

Vale ressaltar que não foi possível mapear o processo de implementação da certificação FSC nas empresas L’Occitane, J\&J e Empresa Y. As empresas X e Flape não compram insumos certificados, mas Pedro Dameto, diretor executivo desta última, afirmou que, caso desejasse passar a compra-los, ele mesmo lideraria a iniciativa, e não seria necessário envolver outros funcionários. Segundo o diretor, o processo deveria ser rápido e simples, dado que envolveria a avaliação se o atual fornecedor possui a certificação ou não e, em caso negativo, buscar outro fornecedor apto no mercado que, segundo ele, tem uma ampla oferta. O executivo deixou claro, porém, que a questão do custo se faz muito relevante para ele, como em todo o processo de compras. Isso vai ao encontro das conclusões de Zaabi, Dhaheri e Diabat (2013), para os quais as pequenas e médias empresas são menos focadas em embalagens ambientalmente amigáveis.

Um último ponto levantado por Pedro Dameto está relacionado à credibilidade da certificação, quando comenta que "[...] ia pedir pra ele sabe o que? O certificado dele, e veria se estava na validade. Ia checar na certificadora se realmente o certificado dele era válido”. Além desta questão levantada por Dameto, um relatório da Rainforest Foundation levantou diversos outros aspectos que agrediriam a credibilidade do FSC, como problemas estruturais no sistema, algumas decisões políticas específicas dentro da organização e a falta de mecanismos de controle efetivos (Counsell \& Loraas, 2002, p.5). Não foi possível encontrar outros artigos relacionados a estes problemas, não tendo sido este o objetivo da pesquisa bibliográfica da presente dissertação.

O relacionamento com stakeholders externos às empresas durante processo de certificação está basicamente limitado aos fornecedores de insumos e às certificadoras, sendo que as padronizadoras não são envolvidas em nenhum momento. Há apenas uma exceção, que é a Natura. Por ter sido a primeira empresa de bem de consumo a utilizar a certificação FSC 
em suas embalagens de papel, foi possível definir, junto com a padronizadora e a certificadora, qual seria o texto a ser aplicado no logotipo do FSC que iria ser estampado no produto, o que foi considerado um diferencial para a empresa.

Para a Mazurky, o apoio de seus fornecedores na obtenção da certificação foi muito importante, ao compartilharem seus conhecimentos acerca do processo de auditoria. Um último ponto a ser ressaltado sobre a relação com stakeholders está na fala da entrevistada da empresa:

[...] o nosso fornecedor tem que ser certificado FSC também, e então foi um trabalho até surpreendente, no começo, que a gente descobriu que todos os nossos fornecedores tinham o FSC e a gente não tinha esse conhecimento. Ninguém tinha oferecido pra gente, era muito pouco divulgado. A gente só sabia de um fornecedor, então quando a gente começou o processo apostava que ia trabalhar só com ele. Conforme a gente foi fazendo o questionamento, a gente foi descobrindo que não, que todos os nossos fornecedores, até os menores, tinham essa certificação [...]. (Elaine, Mazurky)

A falta de troca de informações entre os diversos stakeholders e de proatividade dos fornecedores em ofertarem insumos certificados foram identificadas como barreiras neste processo de implementação da certificação. Uma consolidação dos temas debatidos neste tópico é também apresentada na Tabela 21. Ressalta-se que o custo mais alto do insumo certificado seria uma barreira levantada pela Flape, mas não foi listado na tabela, pois todos os respondentes afirmaram que não há diferença entre o custo dos insumos com e sem certificação. Contudo, optou-se por listar como barreira o desconhecimento sobre o custo da certificação, dado que a crença de que o insumo certificado seria mais caro poderia ser um entrave inicial para empresas que considerassem compra-lo. Neste contexto, esta barreira deveria ser considerada no momento inicial, descrito no tópico anterior, e tal ajuste será realizado quando da consolidação de todas as etapas descritas no caso. 
Tabela 21 - Consolidação: atores envolvidos, tempo/custo e barreiras levantadas (FSC)

\begin{tabular}{|c|c|c|}
\hline $\begin{array}{l}\text { Áreas e stakeholders } \\
\text { externos envolvidos }\end{array}$ & Tempo e custo & Barreiras levantadas \\
\hline $\begin{array}{l}\text { Citados por todas empresas } \\
\text { - Áreas internas: } \\
\text { suprimentos, produção, } \\
\text { projetos e marketing e/ou } \\
\text { comercial } \\
\text { - Stakeholders: certificadora, } \\
\text { fornecedor de insumos } \\
\\
\text { Específicos de uma empresa } \\
\text { - Áreas internas: sistemas de } \\
\text { gestão (inclui auditoria e } \\
\text { qualidade), faturamento, } \\
\text { transporte, meio-ambiente, } \\
\text { inovação (pesquisa } \\
\text { avançada), diretoria } \\
\text { - Stakeholders: parceiros } \\
\text { comerciais }\end{array}$ & $\begin{array}{l}\text { - } 5 \text { a } 10 \text { meses } \\
\text { - Custos de certificação } \\
\text { absorvidos pelas empresas } \\
\text { (máximo de } \mathrm{R} \$ 50 \text { mil e } \\
\text { mínimo de } \mathrm{R} \$ 10 \text { mil para } \\
\text { primeira certificação) }\end{array}$ & $\begin{array}{l}\text { - Falta de pro-atividade de } \\
\text { fornecedores em ofertarem os } \\
\text { insumos certificado e/ou divulgarem } \\
\text { a certificação } \\
\text { - Falta de credibilidade nas ofertas do } \\
\text { mercado acerca da certificação } \\
\text { - Custo inicial da certificação } \\
\text { (adaptação de processos e/ou } \\
\text { auditoria) } \\
\text { - Restrição de mão de obra técnica } \\
\text { para realizar auditorias } \\
\text { - Restrição de mão de obra técnica } \\
\text { para realizar adequações internas } \\
\text { - Esforço interno para implementação } \\
\text { (adequações, treinamentos) } \\
\text { - Falta de aplicação do selo por parte } \\
\text { das empresas que o adotam } \\
\text { - Desconhecimento sobre o custo da } \\
\text { certificação }\end{array}$ \\
\hline
\end{tabular}

Fonte: elaborado pela autora.

\subsubsection{Impactos que a certificação trouxe ao negócio}

Novamente foi difícil encontrar padrões em relação aos impactos que a certificação pode trazer às empresas que a adotam. Como impacto positivo, a Box Print mencionou o diferencial de ter sido a primeira gráfica da América Latina a obter a certificação e a conquista de novos negócios, principalmente entre os clientes que possuem atuação fora do país, pois, segundo Luis Martini, o FSC tem amplo reconhecimento na Europa e nos Estados Unidos. Porém, o percentual de faturamento com a venda de insumos certificados está parado no patamar de $6 \%$ já há algum tempo. Para Martini,

[...] A maioria dos clientes não usa os selos. Isso porque na própria indústria existe esta restrição. (...) Digamos assim, acho que falta domínio de causa, falta conhecimento disso ou, como te falei antes, princípios de marketing, de comunicação com o mercado. Cada empresa tem o seu modelo de valor e dão maior prioridade para isso. $\mathrm{O}$ valor que eles dão pra certificação ainda é pequeno. (...) E aí se esse público não tem esse entendimento, então para o consumidor vai ser menor ainda o impacto disso. 
A Mazurky tem a mesma expectativa de impacto positivo que a Box Print - a de conquistar novos cliente e/ou projetos - mas, dado que havia acabado de obter a certificação quando a entrevista foi realizada, não foi possível levantar se essas expectativas foram atendidas. Contudo, foi possível levantar alguns outros impactos que a certificação causou internamente na empresa, como a ampliação da sua visão de sustentabilidade, incluindo questões ambientais (ex.: economia de água e energia) e sociais (ex.: responsabilidades para com o trabalhador, rastreabilidade da cadeia). Além disso, a entrevistada, Elaine Cristina, ressaltou que o envolvimento de todos da empresa na certificação despertou esse olhar para a sustentabilidade não só em seus diretores executivos, mas em todos os funcionários, para que qualquer um possa ser um agente de transformação de outras mudanças possíveis no processo produtivo. Tal pode ser extraído do seguinte trecho da entrevista com Elaine:

[...] Então com a certificação do FSC, na verdade, abriu um leque, uma visão macro que nós não tínhamos, nós tínhamos uma visão micro aqui dentro e aí depois de conhecer o auditor que veio aqui, super bacana ele também, que deu várias ideias, vários toques pra gente, e aí você percebe que assim, embora seja um selo para o papel, ele envolve muito mais coisa... Água, luz, energia, comportamento. (...) Eles se preocupam com o trabalho escravo, com questão de hora extra, com questão de acidente do trabalho. Então que a gente consiga atender todas as premissas em igualdade (...) Mas que isso abra não só mais a cabeça dos nossos empresários, mas de todos os funcionários, que eles possam trazer inovações e ideias aqui pra dentro e que na medida do possível a gente posso auxiliar todos a implantar o que for bom pra empresa e pra todos nós, que afinal somos um time, né? Não pode ser bom só pra mim, tem que ser bom pra todos. [...]

Ambas as empresas fornecedoras citaram a questão do custo como um impacto negativo - tanto da certificação inicial quanto das auditorias anuais, mas que era algo para o qual já estavam preparados. Eles mencionam, ainda, que se as empresas não aplicassem considerações socioambientais em seus processos produtivos, o custo de adaptação às exigências do FSC poderia ser mais representativo.

A Natura citou como um dos principais impactos positivos a questão de ter sido a pioneira em utilizar a certificação e de poder demandar exclusividade de seus fornecedores (Klabin e Box Print) por um determinado período de tempo. Um impacto que poderia ser esperado pela certificação seria o de melhora no indicador de análise de ciclo de vida (ACV) do produto, o qual a empresa monitora para todos os itens de seu portfolio. Porém, segundo Raquel Badia, a certificação de origem não entrava no cálculo deste indicador e, na realidade, o mais importante é considerar a certificação como mais uma ferramenta que compõe as 
práticas da Natura relacionadas à sustentabilidade, garantindo coerência entre seu discurso e sua gestão cotidiana. Esta questão fica evidente na seguinte fala:

[...] Era mais uma coisa para achar um pouquinho essa sustentabilidade, entendeu? Não era nosso objetivo que o cliente só comprasse porque tinha o selo... é uma inquietação mais genuína, mais interna. A nossa preocupação não é divulgar o selo, mas sim saber que estamos fazendo direito. Divulgamos o selo, sim, mas o que eu estou querendo dizer é que era mais uma preocupação assim "vamos dormir tranquilos, entendeu? Estamos fazendo a nossa parte".

Um ponto considerado crítico pela Natura na gestão da certificação é o controle do número do certificado obtido. Segundo Flavia, a empresa tinha obrigação de colocar este número, mas o mesmo podia mudar em alguns momentos (provavelmente quando da renovação da auditoria), o que acabava impactando a gestão do estoque das embalagens e o controle de qualidade na entrega das mesmas - muitas vezes atualizava-se o sistema interno de cadastro, mas não o sistema com as artes ${ }^{13}$, que dependia da área de marketing. Com isso, a área de qualidade as vezes tinha que barrar a entrada do insumo até que fosse tirar a dúvida sobre o porquê da diferença e se havia a possibilidade de usá-lo com o número de certificado antigo. A entrevistada não soube precisar como está este processo atualmente, dado que saiu há algum tempo da área de embalagens. Porém, ao avaliar as embalagens de três produtos da Natura que contém o FSC, foi possível averiguar que ainda há números diferentes aplicados junto à logomarca da certificação, como pode ser verificado na Tabela 22.

\footnotetext{
${ }^{13}$ Por arte entenda-se um arquivo de imagem com a apresentação estética da embalagem do produto.
} 
Tabela 22 - Produtos Natura com selo FSC

\begin{tabular}{|c|c|c|c|c|}
\hline Produto & $\begin{array}{l}\text { Sabonetes em gomos } \\
\text { Natura Ekos - açaí e } \\
\text { castanha }\end{array}$ & \multicolumn{2}{|c|}{$\begin{array}{l}\text { Sabonete em barra } \\
\text { Tododia - alecrim e sálvia }\end{array}$} & $\begin{array}{l}\text { Creme hidratante } \\
\text { para as mãos Tododia } \\
\text { - macadâmia }\end{array}$ \\
\hline Imagem & 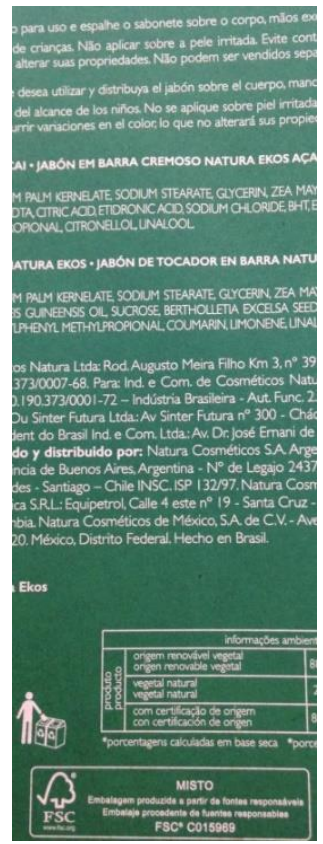 & 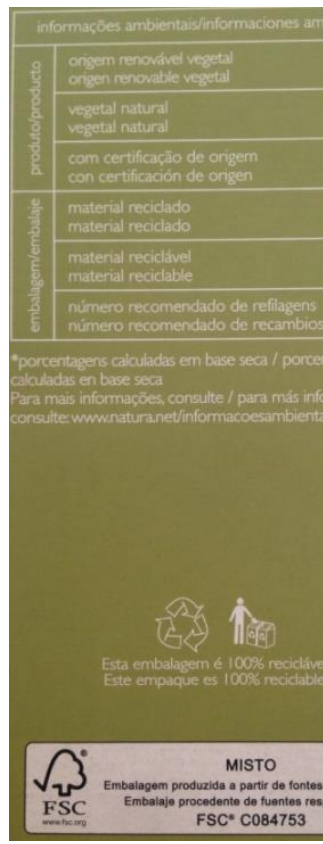 & \begin{tabular}{|c|}
$91.9 \%$ \\
1.26 \\
08 \\
$89,4 \%$ \\
0 \\
\end{tabular} & 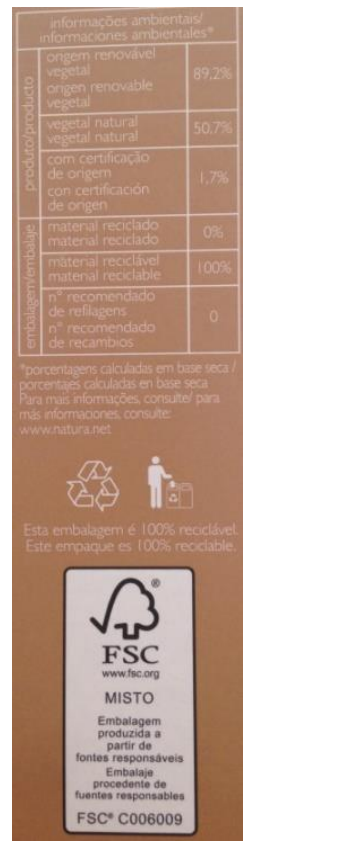 \\
\hline FSC & C015969 & C084753 & & C006009 \\
\hline Validade & 09/2017 & $05 / 2019$ & & 09/2017 \\
\hline
\end{tabular}

Fonte: elaborado pela autora.

Um outro impacto negativo levantado pela empresa esteve relacionado à questão da cor do tipo de papel certificado que foi oferecido pela Klabin na época, que era um pouco mais escura que o papel anterior que era utilizado para embalar o produto.

Para a KC os impactos negativos da certificação estão relacionados com os custos envolvidos até se realizar a auditoria e depois para manter a aprovação do certificado: "Os nossos próprios fornecedores, eles também têm gastos pra certificação, então é um processo bastante caro. Isso agrega custo pra gente, e tem baixo entendimento e retorno do consumidor" (Alfredo Baumbach). Atualmente todos os fornecedores de celulose (principal matéria-prima do segmento de Cuidados com a Família) da KC possuem o FSC. Já os impactos positivos puderam ser retirados do seu relatório de sustentabilidade de 2010, o qual menciona que: 
[...] conseguir o selo traz um conjunto de benefícios diretos e indiretos. O produto se torna diferenciado entre os demais, são derrubadas críticas sociais e ambientais, e uma porta é aberta a novos públicos e mercados (...) dado que o selo estará estampado na embalagem, mostrando todo o esforço da empresa na busca pela sustentabilidade. (Kimberly-Clark, 2010)

Nota-se a valorização da conquista da certificação pela KC, que publicou informações sobre o FSC em todos os seus relatórios anuais de sustentabilidade entre os anos de 2009 e 2012, além de ter como meta publicada o desafio de atingir 50\% do fornecimento de fibras longas com certificação até 2020. Porém, na entrevista com o representante da empresa, foi possível perceber que, assim como na Natura, há uma preocupação mais interna da empresa em deixar seu processo produtivo mais sustentável do que a conquista e/ou manutenção de consumidores, dado que há dúvidas sobre o quanto a certificação seja compreendida e valorizada pelos mesmos, como pode-se depreender do seguinte trecho:

[...] Então eu não sei hoje, eu acredito que não, é percepção minha, tá, que se a gente tirar o I'm Green ou o FSC das nossas embalagens nosso consumidor não vai deixar de comprar o nosso produto. A nossa vontade em ter produtos mais sustentáveis é maior do que qualquer outra coisa, então não é por isso que a gente ia deixar de comprar celulose ou deixar de ter FSC nas nossas notas ou deixar de ter o nosso processo controlado. A gente não ia começar a comprar celulose de desmatamento, é isso que quero dizer, sabe? Nós temos um compromisso com o meio ambiente, e não é o selo que traz esse compromisso. Se não for FSC vai ser outro, se não for I'm Green vai ser outro, mas é uma questão de compromisso e comprometimento da empresa nesse caso, então... Por que o consumidor em si, eu não vejo valorizando ou comprometido com isso. Eu tenho duvidas.

O entrevistado ressaltou que esta questão do consumidor não compreender o que é o FSC é uma percepção particular dele, e disse não ter conhecimento se outras áreas da empresa teriam pesquisas que comprovem tal afirmação. Daniela, do Imaflora, tem opinião similar em relação aos consumidores: "no caso do FSC, a decisão de compra no Brasil está praticamente sendo feita pelos grandes varejistas e não pelo consumidor final. Há pouca demanda direta do consumidor final ainda".

Por último, vale citar que, para Carlos, da $\mathrm{J} \& \mathrm{~J}$, há um valor diferenciado quando uma entidade internacional como o FSC atesta um produto, comprovando que sua cadeia é sustentável e que ele foi aprovado para carregar o seu certificado. Já o entrevistado da Empresa Y, comenta que, na visão de um profissional de marketing, no mercado em que atua, o impacto da certificação é neutro - não traz impactos positivos nem problemas. 
Novamente optou-se por consolidar os principais temas deste tópico na Tabela 23, apresentando os impactos positivos e negativos da certificação e o que foi considerado como barreira neste processo pela pesquisadora. No caso do papel mais escuro mencionado pela Natura, o mesmo não foi considerado barreira, pois esta situação aconteceu quando da primeira certificação a ser feita - conforme mencionado por Raquel Badia, era "o pedágio a ser pago pelo pioneirismo". Atualmente, porém, a oferta de outros papéis certificados é maior, não impactando tanto a questão estética dos produtos.

Tabela 23 - Consolidação: impactos causados e barreiras levantadas (FSC)

\begin{tabular}{|c|c|c|}
\hline Impactos positivos & Impactos negativos & Barreiras levantadas \\
\hline $\begin{array}{l}\text { - Conquista de novos } \\
\text { clientes }\end{array}$ & $\begin{array}{l}\text { - Custo da certificação (inicial e } \\
\text { de manutenção) }\end{array}$ & $\begin{array}{l}\text { - Custo de manutenção da } \\
\text { certificação }\end{array}$ \\
\hline $\begin{array}{l}\text { - Conquista de visão macro } \\
\text { sobre sustentabilidade } \\
\text { (social e ambiental) }\end{array}$ & \multirow{5}{*}{$\begin{array}{l}\text { - Dificuldades na gestão do } \\
\text { número da certificação } \\
\text { - Mudança na aparência do } \\
\text { papel certificado, que ficou um } \\
\text { pouco mais escuro }\end{array}$} & \multirow{5}{*}{$\begin{array}{l}\text { - Baixa demanda de mercado - falta } \\
\text { de reconhecimento e valorização por } \\
\text { parte do consumidor e da cadeia, } \\
\text { como um todo } \\
\text { - Processo de gestão da impressão da } \\
\text { logomarca FSC e do número da } \\
\text { certificação }\end{array}$} \\
\hline $\begin{array}{l}\text { - "Tranquilidade" por estar } \\
\text { fazendo a coisa certa/ } \\
\text { alinhamento com estratégia }\end{array}$ & & \\
\hline $\begin{array}{l}\text { - Diferencial oferecido por } \\
\text { organização internacional }\end{array}$ & & \\
\hline $\begin{array}{l}\text { - Diferencial a ser oferecido } \\
\text { a clientes }\end{array}$ & & \\
\hline $\begin{array}{l}\text { - Pioneirismo na } \\
\text { implementação e } \\
\text { exclusividade por } \\
\text { determinado tempo (natura e } \\
\text { box print) }\end{array}$ & & \\
\hline
\end{tabular}

Fonte: elaborado pela autora.

Note-se que foi possível encontrar alguns estudos que também relataram os impactos que a certificação trouxe às empresas. No artigo de Pinto e Granja (2013), por exemplo, todas as empresas pesquisadas relataram resultados satisfatórios na implementação das certificações florestais: ganhos financeiros (nenhuma delas soube citar o valor do ganho) e melhoria na satisfação dos clientes externos e internos. Segundo os autores, o fato de as empresas não conseguirem mensurar o valor financeiro obtido pela certificação pode ser justificado pela dificuldade em se quantificar os benefícios como a "maior satisfação dos clientes externos", 
sendo que tais indicadores podem ser intangíveis, porém perceptíveis. Nas entrevistas realizadas para a presente pesquisa não foi citada a questão da satisfação de clientes.

Já no estudo de Ham (2007) foi possível levantar também os impactos negativos e positivos listados pelas empresas no caso específico do FSC na África do Sul. Como impactos positivos foram listados a possibilidade de cobrar preços mais altos, acesso a mercados exportadores, credibilidade, melhora nos padrões de qualidade e boa gestão e controle nenhum destes citados pelos entrevistados do presente estudo. O que mais se assemelha é a questão do acesso a mercados exportadores, que poderia estar relacionado ao que foi citado como "conquista de novos clientes". Por outro lado, as empresas listaram como impactos negativos a falta de benefícios de mercado (sendo que, em alguns casos, a certificação é a exigência mínima para exportação), custos e documentações associados à certificação, dificuldades em se atender aos padrões exigidos e problemas na obtenção de madeira certificada. Segundo o autor, os respondentes mencionaram que os custos adicionais e a maior carga administrativa gerada pela certificação são agravados pela vantagem limitada que obtem no mercado - ou seja, não foi possível obter retornos financeiros pelo tempo e dedicação dedicados ao processo de certificação. Comparando com os impactos encontrados na análise das entrevistas, nota-se que a questão dos custos e da falta de valorização do mercado se repetem, assim como a gestão do número da certificação, que poderia estar associada ao que foi colocador por Ham (2007) como aumento de carga administrativa.

Retomando os estudos de Rickenbach e Overdevest (2006), vale citar que os autores aplicaram seu modelo dos tipos ideais de mecanismos de certificação florestal (marketing, aprendizagem e sinalização) numa pesquisa com empresas certificadas nos Estados Unidos, e concluíram que o que gerava maior satisfação era a sinalização para os stakeholders. Porém, foram encontradas diferenças nos níveis de satisfação ao comparar diferentes tipos de empresa: empresas pequenas privadas reportaram satisfação menor do que empresas públicas e empresas grandes privadas para todos os três mecanismos. Outra conclusão do estudo indica que benefícios diretos e substanciais de mercado ainda estavam por se materializar, citando pesquisadores que mostravam que a possibilidade de cobrar um preço maior pelos insumos e/ou produtos certificados ainda não tinha sido comprovada, o que também pode ser abstraído das entrevistas realizadas para esta pesquisa: nenhuma das empresas aumentou seu preço ao utilizar insumos certificados, nem aumentou seu volume de vendas para os mesmos clientes. Algumas empresas citaram a conquista de novos clientes, mas de forma pouco representativa. 


\subsubsection{Consolidação das barreiras}

Neste tópico serão analisadas e classificadas as barreiras levantadas no caso FSC. Ao descrever os casos foi possível mapear as barreiras em cada estágio do processo de implementação da certificação, desde o momento em que se toma conhecimento da mesma e se reconhece quais seriam as motivações para adotá-la, passando pelo processo de se preparar e realizar a auditoria e/ou adquirir insumos certificados, e chegando ao ponto de se avaliar os impactos pós-implementação, conforme foi consolidado na Tabela 24. Note-se que nenhum dos estudos encontrados sobre barreiras à implementação da GCSS havia sistematizado as barreiras desta forma, sendo esta uma proposta original realizada pela autora.

Tabela 24 - Barreiras encontradas em cada etapa da implementação (FSC)

\begin{tabular}{|c|c|c|}
\hline $\begin{array}{l}\text { Pré-implementação } \\
\text { (Fase anterior) }\end{array}$ & $\begin{array}{l}\text { Durante a implementação } \\
\text { (Implementação) }\end{array}$ & $\begin{array}{l}\text { Pós-implementação } \\
\text { (Fase posterior) }\end{array}$ \\
\hline $\begin{array}{l}\text { - Desconhecimento por parte das } \\
\text { empresas } \\
\text { - Falta de demanda de garantia } \\
\text { de origem por parte de } \\
\text { stakeholders } \\
\text { - Falta de política de } \\
\text { sustentabilidade por parte das } \\
\text { empresas } \\
\text { - Falta de envolvimento e/ou } \\
\text { apoio político e/ou priorização } \\
\text { por parte da alta direção } \\
\text { - Baixo envolvimento da área de } \\
\text { marketing na demanda por } \\
\text { certificações } \\
\text { - Rigidez por parte do FSC } \\
\text { (pode afastar possíveis } \\
\text { interessados na certificação) } \\
\text { - Desconhecimento sobre o custo } \\
\text { da certificação }\end{array}$ & $\begin{array}{l}\text { - Falta de pro-atividade de } \\
\text { fornecedores em ofertarem os } \\
\text { insumos certificado e/ou } \\
\text { divulgarem a certificação } \\
\text { - Falta de credibilidade nas } \\
\text { ofertas do mercado acerca da } \\
\text { certificação } \\
\text { - Falta de aplicação do selo por } \\
\text { parte das empresas que o adotam } \\
\text { - Custo inicial da certificação } \\
\text { (adaptação de processos e/ou } \\
\text { auditoria) } \\
\text { - Restrição de mão de obra } \\
\text { técnica para realizar auditoria } \\
\text { - Restrição de mão de obra } \\
\text { técnica para realizar adequações } \\
\text { internas } \\
\text { - Esforço interno para } \\
\text { implementação (adequações, } \\
\text { treinamentos) }\end{array}$ & $\begin{array}{l}\text { - Baixa demanda de mercado - } \\
\text { falta de reconhecimento e } \\
\text { valorização por parte do } \\
\text { consumidor e da cadeia, como } \\
\text { um todo } \\
\text { - Processo de gestão da } \\
\text { impressão da logomarca FSC e } \\
\text { do número da certificação } \\
\text { - Custo de manutenção da } \\
\text { certificação }\end{array}$ \\
\hline
\end{tabular}

Fonte: elaborado pela autora.

Note-se que foi realizada a alteração descrita no tópico 4.1.2, referente ao desconhecimento em relação ao custo da certificação. Esta barreira não havia sido levantada diretamente pelos entrevistados, mas foi considerada pela autora como um obstáculo a 
potenciais entrantes, dado que influencia o momento em que as empresas ainda estão avaliando as questões relacionadas à rotulagem sustentável. Neste caso, elas podem assumir que o custo é mais alto e desistir de seguir na busca de informações. Com isso, mudou-se a barreira da fase de implementação, para a fase de pré-implementação.

Vale resgatar que Pinto e Granja (2013, p.7) listaram os seguintes custos para obtenção das certificações FSC: i) custos para a obtenção do certificado; ii) custos para a adequação de manejo sustentável; e iii) custos referentes à manutenção do certificado. À exceção do manejo, que é referente ao gestor florestal, foi possível identificar todos os custos relacionados pelos autores nas entrevistas do presente estudo, além da questão do desconhecimento, acima mencionada, e do custo referente à adaptação dos processos internos das empresas, caso seja necessário. Este último estaria inserido dentro do tópico "i" relacionado pelos autores.

Em relação à diferença entre stakeholders, foi possível levantar algumas barreiras que são específicas de fornecedores de insumos certificados (vide Tabela 25), e que também são encontradas por empresas de bens de consumo que fazem uso da própria celulose como insumo de seus produtos (e não somente o papel certificado na embalagem), e, consequentemente, também devem obter a certificação, como é o caso da KC.

Tabela 25 - Barreiras específicas de empresas que devem obter certificação FSC

\begin{tabular}{l|l|l}
\hline $\begin{array}{l}\text { Pré-implementação } \\
\text { (Fase anterior) }\end{array}$ & $\begin{array}{l}\text { Durante a implementação } \\
\text { (Implementação) }\end{array}$ & $\begin{array}{l}\text { Pós-implementação } \\
\text { (Fase posterior) }\end{array}$ \\
\hline $\begin{array}{l}\text { - Rigidez por parte do FSC } \\
\text { (pode afastar possíveis } \\
\text { interessados na certificação) }\end{array}$ & $\begin{array}{l}\text { - Custo inicial da certificação } \\
\text { (adaptação de processos e/ou } \\
\text { auditoria) }\end{array}$ & $\begin{array}{l}\text { - Custo de manutenção da } \\
\text { certificação }\end{array}$ \\
$\begin{array}{l}\text { - Restrição de mão de obra } \\
\text { técnica para realizar auditorias } \\
\text { - Esforço interno para } \\
\text { implementação (adequações, } \\
\text { treinamentos) }\end{array}$ & \\
\hline
\end{tabular}

Fonte: elaborado pela autora. 


\subsection{Caso 2-I'm Green}

O selo I'm Green foi lançado pela empresa petroquímica brasileira Braskem no ano de 2010, com objetivo de identificar os produtos que levassem em sua composição o polietileno verde (PE verde), item inovador e com apelo sustentável de seu portfólio de produtos, lançado em escala industrial no mesmo ano. O PE verde faz parte de uma categoria de produtos que pode ser denominada de biopolímeros - materiais produzidos a partir de fontes renováveis e/ou biodegradáveis, que pode ser utilizada na produção de diversos produtos, desde embalagens plásticas até componentes automotivos. Por ser feito com uma matéria-prima de fonte renovável (o etanol, oriundo da cana de açúcar) este material plástico ajuda a capturar e fixar o CO2 da atmosfera, o principal causador do efeito estufa (Braskem, 2017b). A Braskem também ressalta sua preocupação em garantir que a matéria prima do PE verde (etanol) tenha procedência de fornecedores que sigam boas práticas socioambientais, fortalecendo o compromisso com a sustentabilidade no setor sucroalcooleiro (Braskem, 2014).

Segundo Claudia Cappra, gerente comercial da Braskem, o projeto foi iniciado em 2007 por demanda de um de seus clientes, a Toyota, do Japão, que buscava uma resina plástica mais sustentável. Foi a própria Toyota que investiu na planta piloto, a fim de fazer os primeiros desenvolvimentos e testes e, ainda em 2007, a Braskem anunciou que tinha conseguido um certificado internacional comprovando que a resina desenvolvida com o etanol continha 100\% de matéria-prima renovável (Braskem, 2007). Em 2008 a empresa já estava produzindo cerca de 12 toneladas anuais de PE verde, que eram disponibilizadas para realização de testes a empresas nacionais e internacionais interessadas em associar seus produtos ao conceito da sustentabilidade. O primeiro produto comercial com o novo insumo foi anunciado no mesmo ano: um brinquedo de tabuleiro chamado Banco Imobiliário Sustentável, em parceria com a Brinquedos Estrela (Braskem, 2008a). Ainda em 2008 a Braskem e a Toyota assinaram acordo para desenvolver atividades conjuntas para comercialização do PE verde na Ásia, cuja produção em escala industrial estava sendo planejada para início de 2011 (Braskem, 2008c).

Em julho de 2010, antes de ter inaugurado sua nova fábrica, a Braskem já anunciou o lançamento do selo I'm Green, construído para ser simples e direto na comunicação com os diversos públicos, e cujo objetivo era criar valor e identificar, além do PE verde, todos os outros polímeros produzidos pela empresa a partir de matérias-primas renováveis. Segundo 
Rui Chammas, vice-presidente da Unidade de Polímeros, "com a criação do selo estamos estendendo os benefícios da aplicação de uma resina de fonte renovável para o consumidor final, que enxerga e valoriza os produtos com componentes renováveis" (Braskem, 2010). Para fazer uso do selo I'm Green, o cliente deve comprometer-se com alguns requisitos, como a utilização de um percentual mínimo de PE verde no produto final a ser produzido (Mores, 2013). Claudia Cappra justifica que este percentual mínimo, que é de 51\%, foi definido considerando-se que, "como a captura de $\mathrm{CO} 2$ do PE verde é em torno de 2,5 toneladas por cada uma, se você tem $51 \%$ do produto verde você pode ser considerado carbono neutro (...) então você consegue ter esse apelo sustentável".

Para Kristy-Barbara Lange, responsável pela área de comunicação de uma organização que representa os interesses de diversas empresas europeias da cadeia de valor dos bioplásticos (European Bioplastics), 40\% da produção deste tipo de insumo são convertidos em soluções para embalagens (Wolford, 2015), o que é corroborado por Orosk et al.( 2014). A justificativa pode estar na fala de Claudia Cappra, no trecho em que comenta que

“[...] (o uso do insumo faz sentido para) muitas empresas de cosméticos, para as quais o impacto da resina não é tão relevante na embalagem final. É diferente de você falar de sacola, em que $70 \%$ do custo é resina. Quando você vai pra cosméticos, a embalagem representa $5 \%$ do valor total.

Maior fabricante mundial de biopolímeros ${ }^{14}$, a Braskem tem capacidade anual de 200 mil toneladas de produção do plástico verde (Braskem, 2015). Logo que anunciou a produção das primeiras amostras do novo plástico, em 2008, a empresa já considerava que este mercado era de nicho, mas estava sendo cada vez mais valorizado, e com forte demanda especialmente em países em que a questão ambiental tem maior relevância, como Europa, EUA e Japão, sendo que as empresas interessadas estavam dispostas a pagar um prêmio entre 20 a 30\% em relação ao preço da resina tradicional (Braskem, 2008a). Em seu relatório anual de 2012 a empresa afirmou que dois terços do volume comercializado do PE verde destinavam-se ao mercado externo (Braskem, 2012), e na pesquisa de Mores (2013) este número era de 80\%. A evolução no interesse internacional por este tipo de matéria prima também é ressaltada por Wolford (2015), que afirma que a Europa liderou a mudança na adoção de embalagens de fontes renováveis, mas que novas aplicações vem surgindo de outras parte do mundo, como a Ásia e

\footnotetext{
${ }^{14}$ Informação que usa a capacidade instalada das empresas, não a produção no ano.
} 
as Américas do Norte e do Sul. Para Bernick (2016), o mercado global de produtos oriundos da química verde, no qual os biopolímeros se incluem, está projetado para crescer de US\$ 11 bilhões em 2015 para aproximadamente US\$ 100 bilhões em 2020. A oportunidade de mercado é ressaltada pelo número cada vez maior de empresas químicas que reportam o aumento de interesse e demanda deste tipo de produto por parte de seus clientes.

Para garantir a procedência e eficácia do PE verde como um insumo que auxilia na redução dos impactos ambientais das empresas que o adotam, a Braskem realizou a avaliação do ciclo de vida (ACV) do produto, a fim de garantir sua melhor performance ambiental em relação ao PE de petróleo. Além disso, obteve certificados de três diferentes laboratórios e/ou organizações internacionais com objetivo de comprovar que seu conteúdo é renovável (Braskem, 2017a). Esta iniciativa vai ao encontro do que foi citado por Iles e Martin (2013), para quem as empresas de bioplásticos precisam criar o mercado para tal produto e assegurar aos seus clientes de que o material é realmente sustentável.

Em relação aos negócios, vale notar que a Braskem se refere sempre ao estabelecimento de parcerias com os clientes que adotam PE verde, parecendo transcender uma relação puramente comercial. A mesma constatação foi feita por Neutzling e Nascimento (2015), para quem a justificativa seria a busca por aumentar participação de mercado do insumo, por meio da criação de estratégias de compartilhamento de informações, solução conjunta de problemas e até a divulgação de conhecimento relacionado ao uso do material e valores relacionados à sustentabilidade. Esta relação próxima se confirma na entrevista de Claudia Capra, da Braskem, “[...] a gente tem feito parcerias, vínculos com a cadeia, tanto com convertedores, como com o cliente final. A gente se propõe a desenhar o melhor projeto possível para o nosso cliente".

Alguns estudos relacionados ao PE Verde da Braskem foram encontrados, desde um artigo internacional que versa sobre polímeros verdes e cita o produto da empresa como um dos casos mundiais de inovação neste mercado (Mülhaupt, 2013) até uma análise brasileira das atitudes dos consumidores finais (pessoas físicas) em relação ao insumo, que mostrou que a maioria das pessoas já ouviu falar do PE verde, mas muitas não sabem realmente o que ele significa (Kruter et al., 2012). Note-se que nenhum estudo específico sobre o selo I'm Green foi encontrado. Outros estudos serão citados no decorrer da descrição e análise do caso. 
A seguir serão apresentados os resultados da presente pesquisa. Ressalta-se que foi possível mapear o processo inteiro de implementação, desde o seu início, em apenas dois casos, no qual obteve-se acesso a profissionais que participaram dos respectivos projetos Natura e Igaratiba. No caso da KC, o entrevistado participou de parte do projeto e, nos demais, os entrevistados não tiveram envolvimento direto na implementação do insumo certificado em seu portfolio de produtos, e somente tinham algum conhecimento do histórico e da aplicação atual do mesmo.

\subsubsection{Contato inicial e motivações}

Dentre as empresas pesquisadas nota-se que algumas estão entre as pioneiras na adoção do PE verde da Braskem. A J\&J foi a primeira marca de cosméticos do país a iniciar o desenvolvimento de embalagens com o material, em 2009, com a linha de protetores solares Sundown, que foi lançada no verão 2011/2012 (Braskem, 2009). Segundo Carlos Lopes, a Braskem ofereceu o material para diversas empresas do mercado, e a motivação para desenvolver o projeto esteve relacionada com o alinhamento à estratégia da empresa, que tem "toda uma preocupação, uma dedicação pra encontrar cada vez mais matérias primas que sejam sustentáveis... é um compromisso nosso" (Carlos Lopes). Isso também é ressaltado na mensagem divulgada pela Braskem à imprensa quando do anúncio da parceria, na qual Marcelo Scatolini, gerente de categoria da J\&J, mencionou:

[...] A empresa possui diversas outras atividades ligadas à responsabilidade ambiental como tratamento de efluentes, controle de resíduos sólidos, etc. No que diz respeito a embalagens, possuímos diversos projetos de utilização de material reciclado pré e pós-consumo, mas realmente a utilização da resina verde é uma ação inédita da companhia em todo o mundo. (Marcelo Scatolini, conforme citado em Braskem, 2009)

O profissional citou que tal pioneirismo estava relacionado ao histórico da marca Sundown, e afirmou que a $\mathbf{J} \& \mathbf{J}$ seguia avaliando o uso do PE verde em outras linhas de produto e em outras regiões do mundo (Braskem, 2009).

Já a Natura foi a primeira marca de cosméticos que lançou produtos com a resina, já no ano de 2010, nos refis do sabonete líquido para as mãos Erva Doce (Natura, 2010), tendo expandido a utilização do insumo em 2011 para os refis de condicionadores da linha Ekos 
(Natura, 2011). A entrevistada Raquel Badia comentou que vinha pesquisando diversos tipos de biopolímeros desde sua entrada na empresa, em 2005. Ela lembra que a Braskem, ao iniciar as pesquisas para desenvolver seu novo material sustentável, procurou a Natura, que já uma antiga parceira comercial, para levantar suas expectativas em relação ao que seria um tipo ideal de material. Segundo Raquel, uma das grandes dificuldades era encontrar um biopolímero que fosse reciclável, demanda repassada à Braskem, e que conseguiu ser atendida pelo PE verde. Ressalta-se que este mesmo diferencial foi destacado pelos entrevistados da pesquisa de Mores (2013) e Zambanini, Bresciani, Pereira, Souza, e Ortega (2014). Flavia Bartholomeu frisou que a relação com a Braskem era bem próxima, sendo que as conversas sobre novas tecnologias eram uma constante na parceria. Foi por demanda da Natura que a Igaratiba também começou a utilizar a nova resina em larga escala, mas o material já era conhecido pela empresa, dado que ela era parceira da Braskem em vários novos desenvolvimentos de produtos, inclusive deste.

No caso da KC, o entrevistado Alfredo Baumbach declarou que se tomou conhecimento da resina em 2009, por oferta da Braskem, e o projeto de aplicação da mesma nos produtos foi iniciado em 2011, com lançamento em 2012 no papel higiênico da marca Neve, que adotou a causa "Por um Brasil Mais Verde" (Kimberly-Clark, 2012). Em seu relatório de sustentabilidade a $\mathrm{KC}$ ressalta que "a cultura de sustentabilidade que permeia as atividades da empresa já define também o comportamento dos fornecedores, que primeiro incorporaram os conceitos de cuidado socioambiental e agora sabem que é preciso também apresentar matérias--primas que sejam viáveis economicamente" (Kimberly-Clark, 2012, p.50).

Dentre as empresas entrevistadas, a L’Occitane foi a última a adotar o insumo, num lançamento de produtos que aconteceu na França e posteriormente foi exportado para outros 85 países (Braskem, 2013). Segundo Edson Futino, a Braskem ofereceu a resina para a equipe no Brasil, e talvez tivesse oferecido também para a equipe da França, pois um profissional deste país esteve durante um período no escritório brasileiro prospectando novas tecnologias na área de embalagens e, provavelmente, levou a ideia do PE verde para a matriz. Na marca brasileira "L'Occitane au Brésil" o material ainda não é utilizado em nenhuma embalagem, mas há planos de implementação no futuro. O profissional ressaltou que a maioria das embalagens da linha faz uso de outro tipo de plástico, o PET. Note-se que todas as empresas citadas têm uma política de sustentabilidade, e a principal motivação para uso do PE verde é a redução do impacto ambiental de suas operações, alinhada com sua estratégia socioambiental. 
Em relação às empresas que não adotam o PE verde em suas embalagens (Empresa Y, Flape e Empresa X), os três entrevistados desconheciam o insumo, e somente o representante da Flape já tinha visto o logotipo I'm Green, e tinha achado ele "bem marqueteiro, né?" (sic) (Pedro Dameto). Em sua opinião, ele desconhecia o selo, como consumidor final, pois não costuma reparar nas embalagens dos produtos, dado que está acostumado a comprar sempre as mesmas coisas. Como empresário, disse não buscar tais materiais, pelo fato de a sua empresa não buscar um posicionamento sustentável.

O representante da Empresa $X$, por sua vez, respondeu que achava que o selo representava "embalagens de origem renovável", mas deixou claro que não tinha certeza e que não lembrava de ter visto a logomarca antes, "talvez por uma questão de (falta de) divulgação (...)" (entrevistado X). Ao conhecer o insumo, levantou três pontos que seriam considerados numa possível adoção do mesmo: i) a exclusividade de fornecimento por uma única empresa seria um problema: “Tem mais de um fornecedor que produz, ou seja, é um mercado competitivo, ou é só um? Porque se ele quebrar o que eu faço? Eu paro, eu perco o selo, perco tudo..." (entrevistado X); ii) o público-alvo de sua marca é de uma classe social mais baixa e não valorizaria o selo, além de não estar disposto a pagar mais por um produto com esta proposta; e iii) o produto ficaria mais caro pois o custo da matéria prima talvez fosse maior:

“[...] eu chutaria que é mais caro (...) por causa da escala. Porque quando você fala de plástico de origem de petróleo, o mundo inteiro usa, tá difundido, as máquinas fazem, o jeito de fazer é o mesmo, então acaba ficando mais barato. Quando você vai pra uma coisa nova, às vezes você tem que alterar máquinas e processos, então assim, a própria implantação demanda um investimento". (entrevistado X)

Já o Entrevistado Y também não conhecia o insumo da Braskem nem o selo I'm Green; e buscou informações com colegas de outras áreas após aceitar participar da presente pesquisa. Segundo ele, a área de compras conhecia o PE verde e já havia considerado utilizá-lo, porém o custo era muito alto e não compensava naquele momento. Ele também assume que sua empresa tem diminuído a busca por novas tecnologias, muito devido à crise econômica. Em suas palavras: 
“[...] Hoje assim, com crise, você tem uma pressão maior pra entregar resultado, o foco tá muito mais em entregar o resultado de hoje e de tentar minimizar custo, então quando você vem com uma nova embalagem que vai trazer incremento de custo, podem dizer que está perdendo o foco. Não faz sentido".

$\mathrm{O}$ entrevistado $\mathrm{Y}$ ainda fez três outras considerações a respeito do tema: assim como a empresa $\mathrm{X}$, a questão de ter o fornecimento concentrado numa única empresa também seria um problema, pois "multinacionais normalmente não gostam de ficar presas com um fornecedor só". Além disso, há a percepção de falta de proatividade da Braskem na venda do produto:

“[...] Então: é mais caro, é um fornecedor só, e aí pelo o que eu ouvi da pessoa de compras e, de novo, eu não vou ter muita informação, mas é que nem a Braskem também tem feito um super esforço pra vender isso (...) pra ela é assim, é uma coisa que 'ah, tá lá no portfólio e eles fornecem', mas que comercialmente ela não vê um grande esforço da Braskem pra falar 'vamos migrar'. Se o cara quer realmente vender, ele poderia virar e falar 'tá bom, você me dá toda sua embalagem e eu te dou o mesmo preço (da embalagem de PE normal)'. Seria uma forma de conseguir entrar". (entrevistado Y)

A última questão levantada pelo entrevistado Y refere-se à decisão de onde utilizar o novo insumo, caso tomasse a decisão pela sua implementação. O profissional diz que ter o selo na embalagem de um produto regular não faria sentido, e que ele provavelmente usaria em sua linha natural, que faz uso de grãos integrais, ressaltando que é isso que alguns de seus concorrentes fazem. $\mathrm{O}$ maior alinhamento deste tipo de material com produtos mais naturais e/ou saudáveis e/ou sustentáveis pode ser comprovado com outros casos encontrados no mercado, como num lançamento da empresa Wickbold anunciado em 2014, de "pães integrais, sem conservantes, baixo teor de sódio e gordura, e zero aditivo" (Odebrecht, 2014), ou na parceria com a empresa Bimbo, de panificação, para a utilização do PE verde numa linha de produtos orgânica e vegana lançada nos Estados Unidos (Braskem, 2014). Uma consolidação dos principais temas levantados neste tópico está registrada na Tabela 26. 
Tabela 26 - Consolidação: formas de contato, motivações e barreiras levantadas (I'm Green)

\begin{tabular}{|c|c|c|}
\hline Como conheceu & Principais motivações & Barreiras levantadas \\
\hline $\begin{array}{l}\text { - Busca ativa por insumos } \\
\text { sustentáveis } \\
\text { - Oferta da empresa } \\
\text { fornecedora } \\
\text { - Demanda de cliente }\end{array}$ & $\begin{array}{l}\text { - Alinhamento com política de } \\
\text { sustentabilidade (redução de } \\
\text { impacto ambiental pela captura } \\
\text { de CO2) } \\
\text { - Demanda do cliente } \\
\text { - Pioneirismo } \\
\text { - Alinhamento com proposta da } \\
\text { marca } \\
\text { - Inovação } \\
\text { - Diferencial de mercado }\end{array}$ & $\begin{array}{l}\text { - Desconhecimento por parte das } \\
\text { empresas } \\
\text { - Falta de divulgação (por parte da } \\
\text { Braskem) } \\
\text { - Falta de propostas comerciais } \\
\text { diferenciadas (por parte da Braskem) } \\
\text { - Falta de política de sustentabilidade } \\
\text { por parte da empresa } \\
\text { - Falta de valorização do público-alvo } \\
\text { da marca da empresa B2C } \\
\text { - Alinhamento apenas com marcas } \\
\text { com apelo saudável/natural/ } \\
\text { sustentável } \\
\text { - Crise econômica } \\
\text { - Fornecimento exclusivo de uma } \\
\text { única empresa } \\
\text { - Percepção de custo mais alto } \\
\text { - Custo efetivamente mais alto }\end{array}$ \\
\hline
\end{tabular}

Fonte: elaborado pela autora.

Uma motivação citada por Mores (2013) e não mencionada pelos entrevistados desta pesquisa é o objetivo de atingir os consumidores ambientalmente corretos. Já Zambanini et al. (2014) falam na obtenção de um diferencial de mercado, e também relacionam esta conquista ao atendimento de consumidores cada vez mais exigentes. Uma maior discussão sobre a opinião dos entrevistados da presente pesquisa em relação à percepção dos consumidores será feita num tópico posterior a este, que versa sobre os impactos causados pela adoção do insumo.

A questão do custo do PE verde parece ser uma barreira relevante, dado que também encontrou-se referências sobre o tema em outros artigos e reportagens, como será visto a seguir, mas sem ser possível concluir qual seria a diferença em relação ao insumo derivado do petróleo. Faz-se importante registrar que, segundo Mores (2013) o custo para produzir a resina do etanol é praticamente o mesmo de se produzir a resina de origem petroquímica, sendo que a principal diferença se encontra no preço da matéria-prima, o etanol, que depende da questão de safra da cana-de-açúcar, dentre outros aspectos. 
Claudia Cappra, gerente comercial da Braskem, reconhece que o custo é a principal barreira para adoção do material no Brasil, mas não quis mencionar valores, pois os preços variam conforme o volume adquirido e a sua aplicação, o que também é corroborado por Mores (2013). Porém, outros entrevistados chegaram a comentar: "Quando a gente lançou, ele era 50\% mais caro que o PE normal" (Raquel Badia, Natura); "Não é mais do que 10\%, mas já é um custo bastante importante" (Alfredo Baumbach, KC); "Não tenho essa informação de custo hoje, ele oscila muito, mas no lançamento ele chegou a ser 30\%, 40\% mais caro" (Edson Futino, L’Occitane); "Quando lançou era uns 50\% mais caro; hoje eu acredito que seja em torno de uns 20\% a 25\%" (Paulo Toledo, Igaratiba).

Note-se que a variação mencionada pelos profissionais foi grande, assim como encontrado em outras fontes, que diziam que o preço estaria entre $15 \%$ e $66 \%$ mais alto (Guzman, 2010; Iles \& Martin, 2013). Quando anunciou a aprovação do investimento para construção da nova fábrica, em 2008, a Braskem mencionou que "o polietileno verde tem potencial para comandar um prêmio de aproximadamente 30\% sobre o preço do polietileno de origem não-renovável” (Braskem, 2008b). Paulo Toledo, da Igaratiba, é enfático ao dizer que a empresa sempre oferece a nova tecnologia a seus clientes, mas que o custo acaba sendo o único impeditivo, dado que não há restrições técnicas. Em suas palavras:

[...] isso acaba gerando uma questão financeira aí muito forte. Quanto é ser sustentável? Ser sustentável custa caro, mas eu preciso de tudo isso? Eu tenho budget para isso? (...) Num momento que eu chego lá com uma proposta de sustentabilidade, porém 50\% mais cara, esquece! Pega um Boticário da vida, por exemplo, que tem valor agregado nos produtos, mas até hoje eles não têm nenhum produto com PE verde ${ }^{15}$. (Paulo Toledo, Igaratiba)

Em relação à divulgação do PE verde, Claudia Cappra, da Braskem, comenta que o foco das ações da empresa é direcionado às empresas de bens de consumo (que ela chamou de "Brand Owners", ou "donos das marcas", em tradução livre realizada pela autora), sendo que as principais áreas que se procura abordar são a de Sustentabilidade, Marketing, ou Técnica, de Inovação. Ela ressalta que são feitas diversas ações de comunicação, como anúncio em revistas segmentadas, participação em eventos e relacionamento com a imprensa, além de publicações em conjunto com alguns clientes. A entrevistada também mencionou já ter feito abordagens com varejistas, com objetivo de fazer a conversão das suas embalagens das

\footnotetext{
${ }^{15}$ O Boticário lançou, no final de 2016, a primeira linha de produtos da marca que faz uso do PE Verde da Braskem.
} 
marcas próprias, e com alguns representantes do poder público, não tendo recebido atenção destes últimos devido ao fato da produção ainda ter um volume pequeno, de nicho.

Sobre a barreira de ser um único fornecedor, ela afirma que existe, sim, alguma restrição em alguns segmentos específicos, como no setor automobilístico, por exemplo, no qual as empresas, por regra, não podem ter um único fornecedor de um insumo. Nos demais ela ressalta que trabalha com contratos, que incluem estoque de segurança de três a quatro meses, e com isso tem conseguido contornar o tema. Por último, acerca das propostas comerciais, a profissional ressaltou que estabelece parcerias com seus clientes, buscando a melhor solução para cada caso.

\subsubsection{Processo de implementação}

O PE verde é considerado um insumo plástico "drop-in", que, segundo Orosk et al., (2014) “são materiais não-biodegradáveis, obtidos de matéria-prima renovável, que apresentam propriedades técnicas idênticas às suas contrapartidas de origem fóssil (...) cujas especificações permitem sua aplicação de mercado com a infraestrutura existente, sem necessidade de investimentos relevantes" (p.43). Isso significa que as barreiras para implementação do novo insumo na linha de produção não deveriam ser relevantes, o que foi confirmado pelos entrevistados desta pesquisa: "Olha, impacto negativo não teve nenhum porque em termos de processos eu não precisei fazer modificações que impactassem algum custo ou em alguma ineficiência" (Paulo Toledo, Igaratiba); “Tecnicamente eles não mudam tá, a questão do produto acabado não tem nenhuma diferença. Também não tem que fazer adaptações na linha de produção" (Edson Futino, L'Occitane); "Não teve que mudar nada, é igualzinho (...) A gente não teve impacto nenhum em processos, em infraestrutura, nada" (Flavia Bartholomeu, Natura).

Já o custo do material, conforme mencionado anteriormente, é uma das grandes barreiras para sua adoção. No caso da L'Occitane, não houve repasse de custo ao consumidor final porque os produtos que foram lançados com o PE verde eram de uma linha nova, que já foi precificada usando o custo do insumo como um dado. A KC também não repassou o custo ao consumidor final e, segundo Alfredo Baumbach, continua buscando alternativas para ajustálo. Uma das alternativas encontradas, no começo, foi fazer a aquisição do material de forma 
centralizada, para depois repassar aos seus convertedores. Com isso, a empresa conseguiu reunir um volume maior de compra e, consequentemente, reduzir o custo, viabilizando sua utilização. Ao ser questionada sobre este tema, Claudia Cappra comentou que a Braskem fazia isso no início da operação, e que atualmente não costuma mais adotar este tipo de estratégia, mas que atua, sim, estabelecendo parcerias, tanto com convertedores, quanto com o cliente final, desenhando o melhor projeto possível para todos. Em relação à Natura, a entrevistada não soube precisar se o custo maior foi repassado ou não ao consumidor final, mas comentou que não foi difícil fazer a aprovação da utilização, dado que a adoção de insumos cada vez mais sustentáveis era um objetivo da empresa. Por último, como participou do processo da Natura desde o início, a Igaratiba ressaltou que as negociações envolviam sempre as três empresas, sendo que a Natura influenciava muito o preço, mas era a Igaratiba que fazia a compra. Não foi possível avaliar se houve o mesmo tipo de centralização de compras mencionada pela KC.

O prazo para lançar os primeiros produtos com PE verde foi de, aproximadamente, dois a três anos, dado que dependia da construção da nova fábrica por parte da Braskem. Segundo Flavia Bartholomeu, os profissionais da Natura aproveitavam materiais gerados pela planta piloto da Braskem para fazer todos os testes necessários de desenvolvimento de produtos (estabilidade, compatibilidade, migração) e, com isso, foi possível usar o primeiro lote do insumo gerado na fábrica, assim que ela foi inaugurada. No caso da $\mathrm{J} \& \mathrm{~J}$, a parceria foi anunciada em 2009, e o lançamento estava previsto para o verão 2011/2012. Para a KC o desenvolvimento também foi de dois anos, e segue até os dias atuais, dado que ainda são necessárias algumas adequações do insumo para que seja possível aplicar a outros produtos da empresa. Atualmente o prazo só depende dos processos internos de desenvolvimento de um projeto como outro qualquer, pois o fornecimento já está normalizado.

A implementação do novo material requereu a participação de equipes multidisciplinares em todas as empresas. As áreas citadas por todos os entrevistados foram: produção, inovação (pesquisa avançada), projetos, compras, marketing. A KC citou também a área de meio ambiente; a L’Occitane mencionou a área de comunicação, responsável por definir como seria feita a divulgação nas lojas; a Natura incluiu a área de sustentabilidade; e a Igaratiba indicou também a áreas comercial, técnica e a diretoria. Faz-se interessante notar o papel do marketing em cada uma das empresas de bens de consumo: no caso da $\mathrm{KC}$, Alfredo disse que a área foi a patrocinadora do projeto; para a Natura, a participação do marketing era mais 
pontual, para direcionar em qual linha de produtos faria mais sentido usar o material; e para Edson, da L’Occitane,

[...] o marketing é o mais afetado, porque são eles que cuidam da precificação do produto, da parte do final da cadeia, né, da venda, eles são o último elo entre a produção e o comercial, então eles vão ter que entender qual que é o impacto do preço, eles vão ter que aprovar a questão da quantidade, o percentual que a gente pode chegar pra poder aprovar e mandar para o mercado.

No caso das empresas que não adotaram o insumo, as áreas que seriam envolvidas, caso se optasse pela implementação, seriam as mesmas, além de outras que foram mencionadas pelo entrevistado da Empresa Y: "assuntos corporativos, porque é uma coisa da reputação corporativa da empresa, seria mais algo pra gente colocar na história; jurídico, porque é um elemento a mais a ser considerado; e finanças, que apoiam no desenvolvimento do plano de negócios”. O profissional, que é da área de marketing, ressaltou, ainda, uma preocupação em relação ao que seria comunicado quando de um possível lançamento de produto com o insumo: "eu já não teria vantagem de ser o primeiro a colocar, pois já tem outras marcas que colocaram, então não é exclusivo. O quanto que eu poderia fazer barulho em cima disso é uma incógnita, né?”. O mesmo foi levantado no relatório da SustainAbility (2011).

Um dos papéis da área de marketing, então, poderia ser este de definir as linhas de comunicação dos produtos que fazem uso do PE verde, além da utilização, ou não, do selo "I'm Green", nas embalagens e/ou nas demais peças de comunicação desenvolvidas. Das empresas pesquisadas, somente $\mathrm{KC}$ e J\&J usam o selo "I'm Green". Esta pode ser considerada uma barreira ao uso do selo - se todas as empresas que fazem uso do insumo declarassem isso por meio da aplicação da logomarca, ela seria cada vez mais difundida e reconhecida entre os consumidores finais. Porém, algumas empresas não comunicam a utilização na embalagem do produto, como é o caso da empresa de produtos de higiene pessoal Procter\&Gamble (Guzman, 2010), ou o fazem por meio de outros ícones e/ou logotipos desenvolvidos internamente. A Natura, por exemplo, desenvolveu dois ícones para comunicar a fonte renovável da matéria prima utilizada no produto, como pode ser visto na Figura 10, abaixo: 


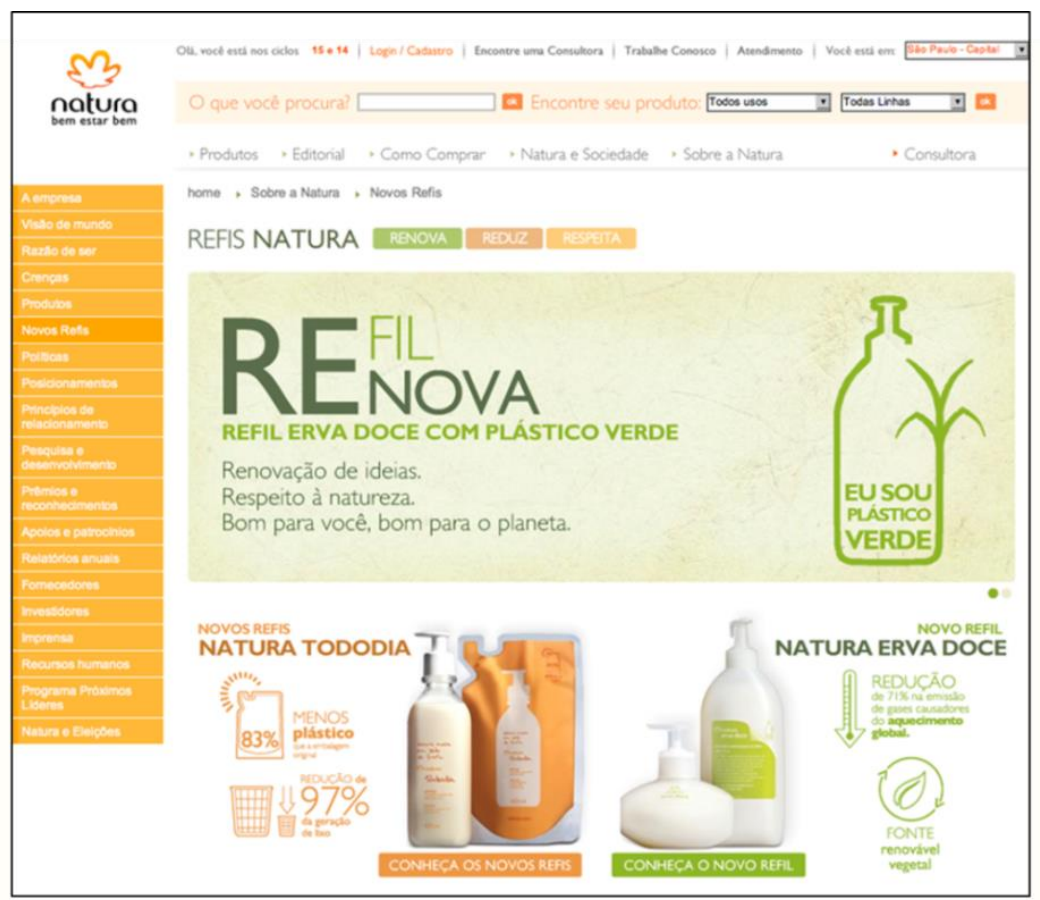

Figura 10 - Comunicação do lançamento de produto com o PE verde da Natura Fonte: site institucional da Natura.

Para Flavia Bartholomeu, isso se deve ao fato de a Natura não ter a prática de fazer associações com outras marcas. Hoje todo o portfolio de produtos que usam PE, o fazem com o insumo verde da Braskem e, ao ser questionada sobre a utilização dos ícones nas embalagens, Flavia não soube responder se esta prática continuava ou não. Para a profissional, talvez o uso do PE verde já tenha virado um "padrão" para a empresa, que optou por não comunicar mais. Porém ela reconhece que, para o consumidor, isto poderia, sim, ainda ser um diferencial. Além disso, ela ressalta que "a empresa tem sempre tantas coisas para comunicar de um único produto, que não é possível transmitir tudo, e tem que ser feito algum tipo de priorização". Os ícones podem ser vistos mais em detalhe na Tabela 27:

Tabela 27 - Ícones desenvolvidos pela Natura para fazer referência ao PE Verde

\begin{tabular}{l|l}
\hline Ícone aplicado nos produtos & $\begin{array}{l}\text { Ícone utilizado em outras } \\
\text { comunicações institucionais }\end{array}$ \\
\hline & $\begin{array}{c}\text { EU SOU } \\
\text { VERTCOE }\end{array}$ \\
\hline
\end{tabular}

Fonte: site institucional da Natura. 
A L'Occitane utiliza o insumo atualmente em dois produtos da França e, de acordo com Edson Futino, comunica-se que a embalagem é de fonte renovável, mas sem aplicar a logomarca nas embalagens. Segundo ele, seus pares na França ressaltaram que o selo não é muito conhecido no país. Recentemente, a marca de cosméticos O Boticário também lançou uma nova linha de produtos que faz uso do PE verde, e criou o ícone "com Plástico Vegetal", que garante a origem da embalagem, e ajuda o consumidor a reconhecer o produto na hora da compra (Braskem, 2016).

Estas práticas de comunicação abrem espaço para duas discussões. Em primeiro lugar, pode-se questionar o quanto uma certificação de terceira parte agrega valor a um produto e/ou a uma marca. Para Claudia Cappra, da Braskem, se uma empresa que possui uma marca forte desenvolve um selo auto-declarado, talvez ele tenha mais força do que um selo de mercado que seja auditado (certificação). O mesmo foi levantado por Raquel Badia, da Natura:

[...] Eu acho que a quantidade de selos, que a gente vê cada vez mais, acaba confundindo o consumidor final, e talvez ele dê menos importância. Eu acho que ele vai muito mais pela confiabilidade na marca, entendeu? "Essa marca me inspira confiança e eu acredito na marca e não necessariamente no selo".

Esta discussão está em linha com o que foi debatido na pesquisa de Hamza e Dalmarco (2012), para quem os apelos de marcas fortes ainda são mais relevantes e críveis para o consumidor final do que a presença de uma certificação. Claudia cita o caso do selo PlantBottle, que foi desenvolvido pela empresa de bebidas Coca-Cola (vide Figura 11) para divulgar o plástico verde que ela utiliza (PET), e que, pela força da marca com a qual está associado, já se faz reconhecido no mundo inteiro.

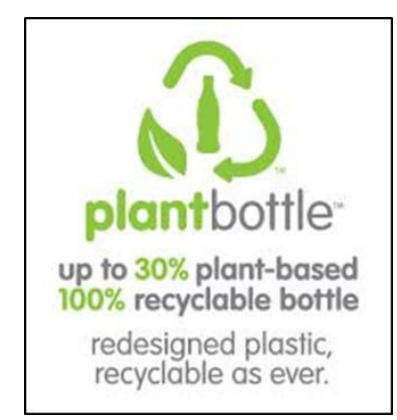

Figura 11 - Selo PlantBottle, da Coca-Cola.

Fonte: http://www.greenerpackage.com/renewable_resources/cokes_plantbottle_makes_debut 
Com isso, Claudia avalia que uma certificação muitas vezes agrega mais valor às empresas pequenas, dado que algumas grandes empresas preferem desenvolver formas próprias de comunicar suas iniciativas de sustentabilidade. Em suas palavras,

[...] se o seu produto tiver o selo I'm Green, por exemplo, ele vai estar na mesma plataforma de comunicação que uma grande rede, como a Kimberly-Clark, a Johnson\&Johnson, enfim, outras empresas no mundo. Então você consegue construir uma plataforma, né, de comunicação, associar a sua marca ao conceito de outras marcas que também tem a mesma plataforma.

Um segundo tema em relação às práticas de comunicação das certificações está relacionado com a profusão de termos e imagens associados a uma mesma definição, e o quanto isso mais confunde do que apoia o consumidor no momento da compra, conforme já debatido no tópico 2.1.3 (formas de comunicar as ISP aos consumidores) do presente trabalho. A executiva Libby Bernick comenta sobre o assunto em um artigo no qual versa sobre "química mais saudável", e defende que a falta de clareza no alinhamento das comunicações pode ser considerada uma barreira, dado que um termo como "química verde" pode suscitar diversas interpretações, desde aspectos relacionados à eficiência de energia até aspectos como baixa toxicidade (Bernick, 2016).

Avaliando apenas os três termos que foram descritos neste tópico para o PE verde, podese perceber que o debate faz sentido: "plástico verde", "fonte renovável vegetal" e "plástico vegetal". Flavia Bartholomeu também questiona a facilidade de se compreender as comunicações:

[...] Não sei se as pessoas entendem que o I'm Green está dentro da fórmula, se está na embalagem... por isso também que a gente criou o plástico verde, né? Está escrito 'plástico', mas também não sei se eles entendem... 'pera aí.. mas o plástico é transparente!', 'o que significa plástico verde?'. A gente tem essa duvida se ele entende, então é difícil essa parte de entendimento e compreensão do consumidor.

Além dos termos mencionados, também existe os ícones desenvolvidos, já apresentados anteriormente. Segundo Iles e Martin (2013), a empresa química Du Pont também mapeou a oportunidade de criar um selo para identificar seus materiais de origem renovável (vide Figura 
12). Das três empresas que os autores pesquisaram, somente a Basf ainda não havia criado um logotipo deste tipo.

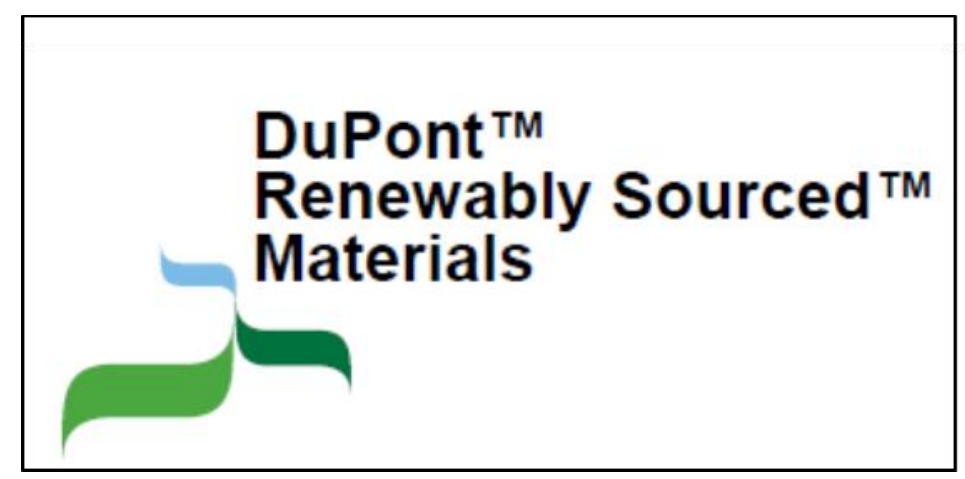

Figura 12 - Selo "materiais de origem renovável”, da empresa DuPont

Fonte: http://www2.dupont.com/Renewably_Sourced_Materials/en_US/materials.html

Flavia também questiona o fato de o termo estar em inglês, assim como o entrevistado Y: “[...] É só escrever 'I'm Green' na embalagem? Quem sabe inglês, até vai entender, mas a dona Maria do Cerrado, talvez não, né?’. Ao ser questionada sobre isso, Claudia Cappra assume que era uma preocupação quando do lançamento do selo, que foi desenvolvido em inglês pelo fato de a Braskem ter identificado uma maior demanda pelo PE verde em empresas de fora do Brasil. Mas ela declara que não teve nenhuma dificuldade e/ou reclamação por parte das companhias brasileiras. Em comunicado à imprensa, a Braskem registra que o selo "é auto referenciável e não apresenta barreiras culturais" (Braskem, 2010).

Por último, vale comentar sobre o relacionamento das empresas de consumo com os seus stakeholders. Uma das pioneiras da adoção do PE verde, a Natura encontrou dificuldades nas negociações iniciais com os seus fornecedores - tanto com a Braskem, em relação à definição de custos, como com os convertedores, pelo receio de usar um novo material. De acordo com Flavia Bartholomeu,

"[...] Não foi fácil a negociação. Eu lembro que tiveram muitas idas e vindas do ponto de vista de compras mesmo, (a área de) Inovação querendo (...), mas 'qual que é o preço disso'? Como que a gente fecha antes de ter tudo feito e o processo estabelecido? Então foi bastante difícil (...) Não fechou o preço antes de começar, mas eles (Braskem) davam um target... assim 'ah, deve ser mais ou menos por aqui', também porque não podia inviabilizar, né?" $[\ldots]$ 
“[...] A negociação com os convertedores não foi tranquila... não é fácil porque eles tem receio de que danifique equipamento, que mude processo, que perca eficiência, então por mais que 'ah, não tem diferença, o processo não vai ser impactado', existe sempre o receio pra usar o material. Eles fazem, mas existe uma negociação... 'olha, vamos colocar, vamos testar, vamos avaliar juntos, vamos entender qual o impacto, se vai ter ou não, na produtividade' (...) de fato uma coisa muito desconhecida traz esse receio [...]"

A entrevistada Flavia comentou, também, que a Braskem apoiou o desenvolvimento com os fornecedores durante todo o processo, sendo que uma das convertedoras da Natura era a própria Igaratiba, que já era parceira da Braskem nos testes do novo material. Isso está em linha com o que foi citado por Orosk et al. (2014), para quem a capacidade de produção dos plásticos tipo "drop-in" foi incluída nas previsões do mercado global devido ao anúncio de que seu desenvolvimento e produção contava com a ativa participação das empresas usuárias como investidoras e/ou compradoras do insumo.

Alguns produtos da $\mathrm{KC}$ e da L'Occitane têm PE verde misturado a outros plásticos. Alfredo Baumbach, da KC, comentou que isso se deve a características dos seus processos industriais, que exigem materiais com mais resistência. O profissional ressalta que a Braskem é aberta para negociação, e que ambas as empresas vão aprendendo juntas nestes desenvolvimentos. Para ele, a relação com os fornecedores foi tranquila, mas desafiadora, já que a base de produto era uma novidade e eles precisaram testar em seus equipamentos também. A seguir, na Tabela 28, é feita uma consolidação dos temas abordados neste tópico. 
Tabela 28 - Consolidação: atores envolvidos, tempo, custo e barreiras levantadas (I'm Green)

\begin{tabular}{|c|c|c|}
\hline $\begin{array}{l}\text { Áreas e stakeholders } \\
\text { externos envolvidos }\end{array}$ & Tempo e custo & Barreiras levantadas \\
\hline $\begin{array}{l}\text { Citados por todas empresas } \\
\text { - Áreas internas: produção, } \\
\text { inovação (pesquisa } \\
\text { avançada), projetos, } \\
\text { suprimentos, marketing } \\
\text { - Stakeholders: fornecedor } \\
\text { de insumos e convertedores } \\
\text { Específicos de uma empresa } \\
\text { - Áreas internas: meio- } \\
\text { ambiente, comunicação, } \\
\text { sustentabilidade, comercial, } \\
\text { técnica, diretoria }\end{array}$ & $\begin{array}{l}\text { Tempo } \\
\text { - Primeiros desenvolvimentos } \\
\text { duraram cerca de } 2 \text { a } 3 \text { anos, } \\
\text { desde conversas iniciais com } \\
\text { Braskem } \\
\text { - Atualmente implementação } \\
\text { leva o tempo de projeto de } \\
\text { desenvolvimento de produtos de } \\
\text { cada empresa } \\
\text { Custo } \\
\text { - Custos em geral não } \\
\text { repassados ao consumidor } \\
\text { - No lançamento de novos } \\
\text { produtos, precificação já } \\
\text { considera o custo como um } \\
\text { dado do projeto }\end{array}$ & $\begin{array}{l}\text { - Custo do insumo } \\
\text { - Negociação de contratos iniciais } \\
\text { (definição de volumes e preços) } \\
\text { - Características físicas do insumo, } \\
\text { que segue sendo desenvolvido para } \\
\text { adequação a outros produtos } \\
\text { - Outros logotipos e termos } \\
\text { desenvolvidos para identificar o } \\
\text { mesmo material } \\
\text { - Não aplicação do selo por parte das } \\
\text { empresas que o adotam } \\
\text { - Pouca divulgação do selo por parte } \\
\text { das empresas que o adotam } \\
\text { - Incerteza em relação a diferenciais } \\
\text { que poderiam ser comunicados, dado } \\
\text { que insumo não seria mais exclusivo }\end{array}$ \\
\hline
\end{tabular}

Fonte: elaborado pela autora.

A boa interação da Braskem com os clientes finais e seus convertedores é citada por Orosk et al. (2014) como um diferencial que a empresa oferece por ser uma grande fabricante de polímeros que já acumulou grande experiência tecnológica da produção do PE convencional, podendo acessar sua própria estrutura de pesquisa e desenvolvimento para desenvolver novas aplicações, conforme vem sendo demandado por empresas como a KC. Os autores ressaltam, também, que o aumento da demanda de plásticos "drop-in" pode ser explicado pelo fato de as barreiras serem menores sob o ponto de vista da demanda, uma vez que os investimentos necessários são relativamente baixos, e que tanto os convertedores quanto as empresas de bens de consumo podem usar tanto o PE verde quanto o PE normal, dado que ambos os materiais possuem as mesmas características (p.49).

\subsubsection{Impactos que a certificação oferece ao negócio}

Foi possível notar as mesmas considerações sobre os impactos causados pela adoção do PE verde por parte das cinco empresas que o utilizam. Seus entrevistados destacaram como 
um dos principais impactos positivos o alinhamento com a estratégia de sustentabilidade da empresa e a melhora nos indicadores ambientais. A Natura, por exemplo, já substituiu todo o seu portfolio que usava PE convencional por PE verde, e agora vem buscando, aos poucos, migrar outras embalagens plásticas (como PET) também para PE, a fim de seguir ampliando a utilização do insumo. Natura e J\&J também ressaltaram a questão do pioneirismo na utilização, sendo que a última valorizou a questão da exclusividade na categoria de proteção solar no Brasil (Braskem, 2009). Claudia Cappra, da Braskem, citou os principais impactos citados por seus clientes: imagem, captura de $\mathrm{CO} 2$ (reduzindo as emissões do processo produtivo e, consequentemente, o impacto ambiental), diferencial de mercado e inovação. A questão da melhora da imagem da empresa também foi mencionada pela entrevistada da Natura, Flavia Bartholomeu:

[...] mantém o reconhecimento da marca sustentável, então acho que é mais um suporte, né? Essas ações fazem sentido e são marcos nossos. A gente olha a linha do tempo, olhando para sustentabilidade e tudo o que a gente fez desde a criação de refil né, uso de pet reciclado, PE Verde, então ele está lá, é mais um marco na construção dessa essência aí com foco e valorização da sustentabilidade.

Em relação ao diferencial de mercado, as empresas reconhecem que este é um impacto positivo, porém todas declararam ter dúvidas em relação ao quanto este tipo de conquista é realmente valorizado pelos consumidores finais e, também, pelas outras empresas, como pode ser visto nas palavras de Paulo Toledo, da Igaratiba: “[...] Olha, hoje o mercado infelizmente não vê (o PE verde) como um grande diferencial. Que é um diferencial, eu acredito que seja, porém o mercado, em função do custo, não valoriza ainda”. No caso da Igaratiba, o único cliente que comprava insumos com PE verde era a Natura. Note-se que a falta de reconhecimento pode ser oriunda tanto pela não valorização deste tipo de ação, quanto pela falta de compreensão do que o selo "I'm Green" e os seus termos relacionados (já mencionados nó tópico anterior) significam.

Como impactos negativos causados pela implementação, as empresas citaram somente a redução na margem dos produtos e, consequentemente, da empresa, devido ao custo mais alto do insumo. Na Tabela 29 registra-se a consolidação dos impactos e as barreiras depreendidas dos mesmos. 
Tabela 29 - Consolidação: impactos causados e barreiras levantadas (I'm Green)

\begin{tabular}{|c|c|c|}
\hline Impactos positivos & Impactos negativos & Barreiras levantadas \\
\hline $\begin{array}{l}\text { - Alinhamento com } \\
\text { estratégia de } \\
\text { sustentabilidade da empresa } \\
\text { - Redução de impacto } \\
\text { ambiental (captura de CO2) } \\
\text { - Diferencial a ser oferecido } \\
\text { a clientes } \\
\text { - Melhora na imagem } \\
\text { - Inovação } \\
\text { - Pioneirismo e } \\
\text { exclusividade em } \\
\text { determinada categoria }\end{array}$ & $\begin{array}{l}\text { - Margem menor dos produtos, } \\
\text { devido ao custo mais alto do } \\
\text { insumo }\end{array}$ & $\begin{array}{l}\text { - Custo do insumo } \\
\text { - Baixa demanda de mercado - falta } \\
\text { de reconhecimento e valorização por } \\
\text { parte do consumidor e da cadeia } \\
\text { como um todo }\end{array}$ \\
\hline
\end{tabular}

Fonte: elaborado pela autora.

Alguns impactos positivos encontrados nas referências bibliográficas e que não estavam entre os mencionados pelos entrevistados da presente pesquisa foram o ganho de participação de mercado (Neutzling \& Nascimento, 2015) e a satisfação de clientes (Mores, 2013). Um possível impacto negativo está relacionado com uma questão levantada por Iles e Martin (2013) sobre a preocupação acerca da garantia de padrões sustentáveis na produção de cana de açúcar, matéria prima do etanol e, consequentemente, do PE verde. Os autores citaram que devido às controvérsias existentes neste fornecimento, no que tange princípios socioambientais, como impactos na Amazônia, e competição com uso da terra para produção de alimentos, foi criado um código de conduta para seus fornecedores, a fim de garantir adequação dos mesmos com as regras definidas pela empresa.

Neutzling e Nascimento (2015) também levantam esta questão, e registram que a Braskem exige certificações de seus fornecedores de etanol, que geralmente tem uma produção verticalizada - ou seja, são responsáveis tanto pela produção da cana de açúcar, quanto pela sua transformação no biocombustível. As certificações mencionadas pelos autores são a ISCC (certificação internacional de biomassa e biocombustíveis sustentáveis) e Bonsucro (certificação internacional de produção de cana de açúcar e etanol). Num outro artigo que menciona a disputa das terras para cultivo de cana-de-açúcar versus as terras destinadas a plantações de outros alimentos, “[...] pode-se observar que algumas das empresas entrevistadas se consideram como apenas consumidoras da resina, e este assunto deve ser 
planejado pelos países e latifundiários. Outros consideram que ainda existem a possibilidades de aumento de áreas cultiváveis, e que isto pode ser resolvido sem grandes problemas" (Zambanini et al., 2014, p.444).

Presente em três referências diferentes, este risco de ter a imagem do selo associada a problemas socioambientais na plantação da cana de açúcar pode ser considerada uma barreira, e será inclusa na tabela que consolida as barreiras, que será apresentada no próximo tópico. Faz-se importante ressaltar, porém, que em pesquisa de dados secundários, somente uma notícia oriunda de um periódico foi encontrada relacionando o tema da monocultura da cana de açúcar no estado do Rio Grande do Sul ao fornecimento para a Braskem (Correio do Povo, 2011), e nenhuma menção ao tema foi feita pelos entrevistados desta dissertação.

\subsubsection{Consolidação das barreiras}

Neste tópico serão consolidadas as barreiras levantadas no caso "I'm Green", como no caso FSC, conforme cada estágio do processo de implementação, desde o momento em que se toma conhecimento da mesma e se reconhece quais seriam as motivações para adotá-la, passando pelo processo de se preparar e realizar a auditoria e/ou adquirir insumos certificados, e chegando ao ponto de se avaliar os impactos pós-implementação, conforme foi consolidado na Tabela 30 . 
Tabela 30 - Barreiras encontradas em cada etapa da implementação (I'm Green)

\begin{tabular}{|c|c|c|}
\hline $\begin{array}{l}\text { Pré-implementação } \\
\text { (Fase anterior) }\end{array}$ & $\begin{array}{l}\text { Durante a implementação } \\
\text { (Implementação) }\end{array}$ & $\begin{array}{l}\text { Pós-implementação } \\
\text { (Fase posterior) }\end{array}$ \\
\hline $\begin{array}{l}\text { - Desconhecimento por parte das empresas } \\
\text { - Falta de divulgação (por parte da } \\
\text { Braskem) } \\
\text { - Falta de propostas comerciais } \\
\text { diferenciadas (por parte da Braskem) } \\
\text { - Falta de política de sustentabilidade por } \\
\text { parte da empresa } \\
\text { - Falta de valorização do público-alvo da } \\
\text { marca da empresa B2C } \\
\text { - Alinhamento apenas com marcas com } \\
\text { apelo saudável/natural/ sustentável } \\
\text { - Crise econômica } \\
\text { - Fornecimento exclusivo de uma empresa } \\
\text { - Percepção de custo mais alto } \\
\text { - Custo efetivamente mais alto }\end{array}$ & $\begin{array}{l}\text { - Custo do insumo } \\
\text { - Negociação de contratos iniciais } \\
\text { (definição de volumes e preços) } \\
\text { - Características físicas do insumo, } \\
\text { que segue sendo desenvolvido para } \\
\text { adequação a outros produtos } \\
\text { - Outros logotipos e termos } \\
\text { desenvolvidos para identificar o } \\
\text { mesmo material } \\
\text { - Não aplicação do selo por parte das } \\
\text { empresas que o adotam } \\
\text { - Pouca divulgação do selo por parte } \\
\text { das empresas que o adotam } \\
\text { - Incerteza em relação a diferenciais } \\
\text { que poderiam ser comunicados, dado } \\
\text { que insumo não seria mais exclusivo }\end{array}$ & $\begin{array}{l}\text { - Custo do insumo } \\
\text { - Baixa demanda de mercado - } \\
\text { falta de reconhecimento e } \\
\text { valorização por parte do } \\
\text { consumidor e da cadeia como } \\
\text { um todo } \\
\text { - Risco de associação de marca } \\
\text { com problemas relacionados à } \\
\text { produção de cana de açúcar }\end{array}$ \\
\hline
\end{tabular}

Fonte: elaborado pela autora.

Uma primeira análise já mostra que as barreiras estão concentradas na fase préimplementação, sendo que a última é bem menos expressiva. Uma das barreiras mais presentes está relacionada ao tema da aplicação ou não do selo "I'm Green" nas embalagens dos produtos. Conforme reconhecido por Claudia Cappra, da Braskem, ao se referir à opção da Natura de não aplicar o selo "I'm Green" em seus produtos, "essa é uma decisão da companhia". A executiva entende que a plataforma própria da empresa faz mais sentido do que usar uma certificação de terceiros" - ou seja, pode-se sugerir que, mesmo que o selo "I'm Green" fosse altamente reconhecido, ainda assim algumas empresas optariam por não utilizálo, pois priorizam suas próprias estratégias de comunicação de suas ações sustentáveis, de forma mais integrada. Já foi feita uma referência ao tema no tópico 4.2.2., porém, dada a sua complexidade, não será possível evoluir esta discussão no presente trabalho, restando a indicação de que este seria um tópico para estudos futuros.

Em relação à diferença entre stakeholders, não foi possível encontrar barreiras específicas a nenhum deles. Faz-se importante relembrar que existe apenas um fornecedor do PE verde (Braskem), e que tanto as empresas B2B quanto as B2C não precisam obter certificação, o 
que pode influenciar a falta de diferenciação entre as barreiras. No próximo tópico será feita a comparação entre os casos.

\subsection{Comparativo entre casos}

Neste tópico serão analisadas e comparadas as conclusões de cada caso em relação às barreiras e às áreas envolvidas na implementação das certificações, com objetivo de ressaltar diferenças e semelhanças entre eles. Uma primeira etapa deste processo foi comparar as barreiras citadas em cada estágio do seu processo de implementação de cada empresa. Note-se que após analisar os dois os casos de forma aprofundada, foi possível detectar que algumas das barreiras citadas em apenas algum deles, poderiam certamente ser aplicadas ao outro, o que foi sugerido pela autora, a fim de desenhar o quadro final de comparação mais realista possível. Com este mesmo objetivo, foi avaliado se seria necessário fazer algum outro ajuste, e procedeu-se à retirada da barreira "negociação de contratos iniciais (definição de volumes e preços)", relacionada à fase de implementação do "I'm Green", dado que se referia à época do lançamento do produto. As barreiras comuns para ambas as certificações são apresentadas na Tabela 31.

Tabela 31 - Barreiras semelhantes encontradas nos dois casos

\begin{tabular}{l|l}
\hline \multirow{2}{*}{ Etapa } & Barreiras comuns para ambos \\
\hline \multirow{4}{*}{ Fase anterior } & Desconhecimento por parte das empresas \\
\cline { 2 - 2 } & Falta de divulgação (por parte de padronizadoras e fornecedores) \\
\cline { 2 - 2 } & Falta de política de sustentabilidade por parte da empresa \\
\cline { 2 - 2 } & Falta de propostas comerciais diferenciadas \\
\cline { 2 - 2 } & Falta de valorização do público-alvo da marca da empresa B2C \\
\cline { 2 - 2 } & Falta de envolvimento e/ou apoio político e/ou priorização por parte da alta direção \\
\cline { 2 - 2 } & Baixo envolvimento da área de marketing na demanda por certificações \\
\hline \multirow{2}{*}{ Implementação de garantia de origem por parte de stakeholders } \\
\cline { 2 - 2 } & Falta de aplicação do selo por parte das empresas que o adotam \\
\hline & Pouca divulgação do selo por parte das empresas que o adotam \\
\hline \multirow{2}{*}{ Fase posterior } & $\begin{array}{l}\text { Baixa demanda de mercado - falta de reconhecimento e valorização por parte do } \\
\text { consumidor e da cadeia, como um todo }\end{array}$ \\
\hline
\end{tabular}

Fonte: elaborado pela autora. 
Note-se que as ambas as certificações têm suas barreiras concentradas na fase inicial do processo, na qual também concentram-se as semelhanças encontradas entre as duas. Uma semelhança mapeada entre os dois selos está ligada à sua aplicação na embalagem, que já foi um pouco debatida em tópicos anteriores (4.2.2 e 4.2.4). O fato de algumas empresas não fazerem questão de fazer uso dos mesmos sugere que eles não oferecem um valor agregado, e a falta de uso por quem o adota faz por piorar esta situação, ao não permitir que ele se faça mais conhecido, e também que esteja relacionado a marcas fortes, que poderiam suportar sua valorização. Isso é o que acontece com a Mars, por exemplo, que declarou a iniciativa de usar o seu conhecimento interno de marketing para engajar consumidores nas causas direcionadas pelas certificações que eles utilizam, de maneira que eles ajudam as marcas destas certificações a crescer (Daniel Vennard, conforme citado em SustainAbility, 2011). Uma outra sugestão de justificativa para tal comportamento das empresas pode estar relacionada com o que foi descrito no relatório da SustainAbility (2011) sobre o caso da Nestlé, que considera as certificações sob uma perspectiva mais operacional do que de comunicação para com o consumidor - ou seja, ela se resguarda por estar utilizando os padrões sustentáveis em sua produção, e faz uso da comunicação na embalagem em países e/ou regiões em que há uma maior demanda dos consumidores em relação ao tema. Este tipo de comportamento também foi levantado nas entrevistas da Natura e da KC.

Propõe-se que um possível estudo futuro poderia avaliar como estas barreiras são interrelacionadas. Como exemplo, pode-se praticamente afirmar que, uma das razões pela falta de conhecimento das certificações por parte das empresas estaria relacionada com a falta de divulgação das mesmas por parte do FSC e da Braskem. Outro exemplo claro seria que a falta de valorização do público-alvo da marca da empresa B2C influencia diretamente o baixo envolvimento da área de marketing na demanda por certificações, e acaba resultando na falta de aplicação e/ou divulgação do selo por parte das empresas que o adotam. Da mesma forma, outras suposições poderiam ser propostas e comprovadas por meio de pesquisa empírica. As barreiras distintas entre as certificações são apresentadas na Tabela 32. 
Tabela 32 - Barreiras distintas encontradas nos dois casos

\begin{tabular}{|c|c|c|}
\hline Barreira I'm Green & Etapa & Barreira FSC \\
\hline Crise econômica & \multirow{5}{*}{ Fase anterior } & $\begin{array}{l}\text { Rigidez por parte do FSC (pode afastar } \\
\text { possíveis interessados na certificação) }\end{array}$ \\
\hline Fornecimento exclusivo de uma empresa & & Desconhecimento sobre o custo da certificação \\
\hline Percepção de custo mais alto & & \\
\hline Custo efetivamente mais alto & & \\
\hline \multicolumn{2}{|l|}{$\begin{array}{l}\text { Alinhamento apenas com marcas com apelo } \\
\text { saudável/natural/ sustentável }\end{array}$} & \\
\hline Custo do insumo & \multirow{6}{*}{ Implementação } & $\begin{array}{l}\text { Falta de credibilidade nas ofertas do mercado } \\
\text { acerca da certificação }\end{array}$ \\
\hline $\begin{array}{l}\text { Características físicas do insumo, que segue } \\
\text { sendo desenvolvido para adequação a outros } \\
\text { produtos }\end{array}$ & & $\begin{array}{l}\text { Restrição de mão de obra técnica para realizar } \\
\text { auditorias }\end{array}$ \\
\hline $\begin{array}{l}\text { Outros logotipos e termos desenvolvidos } \\
\text { para identificar o mesmo material }\end{array}$ & & $\begin{array}{l}\text { Restrição de mão de obra técnica para realizar } \\
\text { adequações internas }\end{array}$ \\
\hline $\begin{array}{l}\text { Incerteza em relação a diferenciais que } \\
\text { poderiam ser comunicados, dado que } \\
\text { insumo não seria mais exclusivo }\end{array}$ & & $\begin{array}{l}\text { Custo inicial da certificação (adaptação de } \\
\text { processos e/ou auditoria) }\end{array}$ \\
\hline \multirow[t]{2}{*}{$\begin{array}{l}\text { Negociação de contratos iniciais (definição } \\
\text { de volumes e preços) }\end{array}$} & & $\begin{array}{l}\text { Falta de pro-atividade de fornecedores em } \\
\text { ofertarem os insumos certificado e/ou } \\
\text { divulgarem a certificação }\end{array}$ \\
\hline & & $\begin{array}{l}\text { Esforço interno para implementação } \\
\text { (adequações, treinamentos) }\end{array}$ \\
\hline Custo do insumo & \multirow[b]{2}{*}{ Fase posterior } & Custo de manutenção da certificação \\
\hline $\begin{array}{l}\text { Risco de associação de marca com } \\
\text { problemas relacionados à produção de cana } \\
\text { de açúcar }\end{array}$ & & $\begin{array}{l}\text { Processo de gestão da impressão da logomarca } \\
\text { FSC e do número da certificação }\end{array}$ \\
\hline
\end{tabular}

Fonte: elaborado pela autora.

Faz-se importante ressaltar que questões relacionadas a custos aparecem como barreiras em todas as etapas de ambas as certificações, mostrando ser um dos grandes empecilhos à maior adoção das certificações sustentáveis. A diferença principal entre os dois selos está relacionada à sua forma de obtenção e fornecimento: a Braskem fornecendo o insumo já certificado, sendo que o obstáculo é o custo do insumo em si; já no caso do FSC, os custos estão associados à preparação, obtenção e manutenção da certificação, conforme já apresentado no tópico 4.1.4 do presente trabalho. Sugere-se considerar a barreira de custo mais crítica para o FSC, em relação ao desconhecimento do mesmo, dado que, no final da cadeia, o insumo certificado acaba não sendo mais caro do que o sem certificação. 
Outra diferença mapeada se refere à iniciativa de se desenvolver ícones diferenciados para substituir o selo já desenvolvido pela Braskem, iniciativa esta que não acontece no caso FSC. Uma das justificativas possíveis poderia ser a força de marca, dado que o FSC é uma organização internacional presente no mundo inteiro e com muito mais tempo de atuação do que o "I'm Green”, que é brasileiro, oriundo de uma única empresa, e tem apenas seis anos no mercado. Porém, esta diferença relacionada à força da marca não seria suficiente para explicar a questão da falta de credibilidade, que foi levantada somente em relação ao FSC, assim como a sua rigidez, que, supõe-se, aumentaria a confiança na certificação. Supõe-se que o fato de ser um esquema que envolve diversos atores, como a padronizadora, e diversas certificadoras, que podem auditar em seu nome, aumenta a chance de ocorrer fraudes em alguma parte do processo, como foi citado, por exemplo, por Counsell e Loraas (2002).

\subsection{Classificação das barreiras encontradas nos casos}

Para avançar na análise, conforme descrito na seção 3.5 - Tratamento e análise dos dados, foi utilizada a classificação das barreiras à GCSS proposta por Walker e Jones (2012) para se proceder a classificação das barreiras encontradas em ambos os casos (vide Tabelas 33, 34 e 35). Para cada barreira listada, procedeu-se uma análise para registrar se ela é externa ou interna à empresa, a qual categoria e subcategorias do modelo de Walker e Jones (2012) ela estaria mais alinhada, o que foi registrado na coluna "classificação". Foi possível notar que há grande aderência entre as barreiras encontradas nas duas linhas de estudo, sendo que em muitos casos foi possível utilizar as categorias e subcategorias que já tinham sido propostas pelos autores. Nestes casos, apenas registrou-se a classificação, da seguinte forma: primeiro se ela é interna ou externa, depois a qual categoria ela está mais alinhada e, por fim, entre parênteses, a qual subcategoria ela está mais alinhada. Como exemplo, pode-se citar a barreira "Falta de envolvimento e/ou apoio político e/ou priorização por parte da alta direção", que conta a seguinte classificação: Interna, pessoas (falta de comprometimento dos gestores).

Em outros casos, porém, foi necessário fazer a proposta de novas categorias e subcategorias. Este exercício está registrado na coluna "classificação" das Tabelas 33, 34 e 35. Vale ressaltar que cada barreira pôde ser classificada em categorias diferentes, de acordo com sua natureza e impacto no processo. As novas categorias ou subcategorias propostas já 
eram consideradas na classificação das barreiras subsequentes, e este fato foi ressaltado por meio de notas de rodapé, com objetivo de fazer este registro e facilitar a compreensão do processo de classificação realizado. A Tabela 33 conta com as barreiras que são comuns aos dois casos.

Tabela 33 - Classificação das barreiras comuns encontradas em cada etapa

\begin{tabular}{|c|c|c|}
\hline Etapa & Barreira & Classificaçãa \\
\hline \multirow{6}{*}{ Fase anterior } & $\begin{array}{l}\text { Desconhecimento por parte das } \\
\text { empresas }\end{array}$ & $\begin{array}{l}\text { Externa } \\
\text { Nova categoria: geral } \\
\text { Nova subcategoria: falta de conhecimento, } \\
\text { compreensão e valorização das cerificações }\end{array}$ \\
\hline & $\begin{array}{l}\text { Falta de divulgação (por parte de } \\
\text { certificadoras, padronizadoras e } \\
\text { fornecedores) }\end{array}$ & $\begin{array}{l}\text { Externa, fornecedor } \\
\text { Nova subcategoria: falta de pro-atividade na oferta de } \\
\text { insumos certificados } \\
\text { Externa } \\
\text { Nova categoria: padronizador } \\
\text { Nova subcategoria: falta de divulgação } \\
\text { Externa } \\
\text { Nova categoria: certificador } \\
\text { Nova subcategoria: falta de divulgação }\end{array}$ \\
\hline & $\begin{array}{l}\text { Falta de política de sustentabilidade } \\
\text { por parte das empresas }\end{array}$ & $\begin{array}{l}\text { Interna, questões estratégicas } \\
\text { Nova subcategoria: falta de política de sustentabilidade }\end{array}$ \\
\hline & $\begin{array}{l}\text { Falta de demanda de garantia de } \\
\text { origem por parte de stakeholders }\end{array}$ & $\begin{array}{l}\text { Externa, geral }^{16} \\
\text { Nova subcategoria: falta de demanda de mercado }\end{array}$ \\
\hline & $\begin{array}{l}\text { Falta de propostas comerciais } \\
\text { diferenciadas }\end{array}$ & $\begin{array}{l}\text { Externa, fornecedor (falta de pro-atividade na oferta de } \\
\text { insumos certificados) }\end{array}$ \\
\hline & $\begin{array}{l}\text { Falta de valorização do público-alvo } \\
\text { da marca da empresa B2C }\end{array}$ & $\begin{array}{l}\text { Externa, geral }^{18} \text { (falta de conhecimento, compreensão e } \\
\text { valorização das cerificações) }{ }^{19}\end{array}$ \\
\hline \multirow{2}{*}{ Fase anterior } & $\begin{array}{l}\text { Falta de envolvimento e/ou apoio } \\
\text { político e/ou priorização por parte da } \\
\text { alta direção }\end{array}$ & $\begin{array}{l}\text { Interna, pessoas (falta de comprometimento dos } \\
\text { gestores) }\end{array}$ \\
\hline & $\begin{array}{l}\text { Baixo envolvimento da área de } \\
\text { marketing na demanda por } \\
\text { certificações }\end{array}$ & $\begin{array}{l}\text { Interna, questões estratégicas } \\
\text { Nova subcategoria: baixo envolvimento da área de } \\
\text { marketing na demanda por certificações }\end{array}$ \\
\hline \multirow[t]{2}{*}{ Implementação } & $\begin{array}{l}\text { Falta de aplicação do selo por parte } \\
\text { das empresas que o adotam }\end{array}$ & $\begin{array}{l}\text { Interna, questões estratégicas } \\
\text { Nova subcategoria: marketing - definições de produtos } \\
\text { e comunicação }\end{array}$ \\
\hline & $\begin{array}{l}\text { Pouca divulgação do selo por parte } \\
\text { das empresas que o adotam }\end{array}$ & $\begin{array}{l}\text { Interna, questões estratégicas (marketing - definições } \\
\text { de produtos e comunicação) }\end{array}$ \\
\hline Fase posterior & $\begin{array}{l}\text { Baixa demanda de mercado - falta } \\
\text { de reconhecimento e valorização por } \\
\text { parte do consumidor e da cadeia, } \\
\text { como um todo }\end{array}$ & $\begin{array}{l}\text { Externa, geral }{ }^{21} \text { (falta de conhecimento, compreensão e } \\
\text { valorização das cerificações) })^{22}\end{array}$ \\
\hline
\end{tabular}

Fonte: elaborado pela autora a partir de Walker e Jones (2012), das referências bibliográficas e dos dados empíricos coletados para o presente trabalho.

\footnotetext{
${ }^{16}$ Considerando nova categoria proposta anteriormente.

${ }^{17}$ Considerando nova subcategoria proposta anteriormente.

${ }^{18}$ Considerando nova categoria proposta anteriormente.

${ }^{19}$ Considerando nova subcategoria proposta anteriormente.

${ }^{20}$ Considerando nova subcategoria proposta anteriormente.

${ }^{21}$ Considerando nova categoria proposta anteriormente.

${ }^{22}$ Considerando nova subcategoria proposta anteriormente.
} 
Na Tabela 34 classificou-se as barreiras específicas do caso FSC:

Tabela 34 - Classificação das barreiras específicas do FSC encontradas em cada etapa

\begin{tabular}{|c|c|c|}
\hline Etapa & Barreira & Classificação \\
\hline \multirow[b]{2}{*}{ Fase anterior } & $\begin{array}{l}\text { Rigidez por parte do FSC (pode } \\
\text { afastar possíveis interessados na } \\
\text { certificacão) }\end{array}$ & $\begin{array}{l}\text { Externa, padronizador }{ }^{23} \\
\text { Nova subcategoria: critérios da padronização }\end{array}$ \\
\hline & $\begin{array}{l}\text { Desconhecimento sobre o custo da } \\
\text { certificação }\end{array}$ & $\begin{array}{l}\text { Interna, integração interna (comunicação) } \\
\text { Interna, questões funcionais (função da área de } \\
\text { compras) } \\
\text { Externa, fornecedor (falta de pro-atividade na } \\
\text { oferta de insumos certificados) }\end{array}$ \\
\hline \multirow{2}{*}{ Implementação } & $\begin{array}{l}\text { Falta de proatividade de } \\
\text { fornecedores em ofertarem os } \\
\text { insumos certificado e/ou divulgarem } \\
\text { a certificação }\end{array}$ & $\begin{array}{l}\text { Externa, fornecedor (falta de pro-atividade na } \\
\text { oferta de insumos certificados) } \text { s }^{25}\end{array}$ \\
\hline & $\begin{array}{l}\text { Falta de credibilidade nas ofertas do } \\
\text { mercado acerca da certificação }\end{array}$ & $\begin{array}{l}\text { Externa, padronizador } \\
\text { Nova subcategoria: transparência na definição } \\
\text { de critérios } \\
\text { Externa, competidores (maquiagem verde) }\end{array}$ \\
\hline \multirow{4}{*}{ Implementação } & $\begin{array}{l}\text { Custo inicial da certificação } \\
\text { (adaptação de processos e/ou } \\
\text { auditoria) }\end{array}$ & $\begin{array}{l}\text { Externa, certificador }{ }^{26} \\
\text { Nova subcategoria: custo da auditoria } \\
\text { Interna, questões funcionais } \\
\text { Nova subcategoria: esforço de coordenação e } \\
\text { complexidade }\end{array}$ \\
\hline & $\begin{array}{l}\text { Restrição de mão de obra técnica } \\
\text { para realizar auditorias }\end{array}$ & $\begin{array}{l}\text { Externa, certificador }{ }^{27} \\
\text { Nova subcategoria: escala e abrangência }\end{array}$ \\
\hline & $\begin{array}{l}\text { Restrição de mão de obra técnica } \\
\text { para realizar adequações internas }\end{array}$ & $\begin{array}{l}\text { Interna, questões funcionais } \\
\text { Nova subcategoria: estrutura organizacional }\end{array}$ \\
\hline & $\begin{array}{l}\text { Esforço interno para implementação } \\
\text { (adequações, treinamentos) }\end{array}$ & $\begin{array}{l}\text { Interna, questões funcionais (esforço de } \\
\text { coordenação e complexidade) }\end{array}$ \\
\hline \multirow[b]{2}{*}{ Fase posterior } & Custo de manutenção da certificação & $\begin{array}{l}\text { Externa, certificador }^{29} \text { (custo da auditoria) }^{30} \\
\text { Interna, questões estratégicas (limitação de } \\
\text { recursos) }\end{array}$ \\
\hline & $\begin{array}{l}\text { Processo de gestão da impressão da } \\
\text { logomarca FSC e do número da } \\
\text { certificação }\end{array}$ & $\begin{array}{l}\text { Interna, questões funcionais (esforço de } \\
\text { coordenação e complexidade) } \\
\\
\text { Externa, padronizador }{ }^{32} \text { (critérios de } \\
\text { padronização) }\end{array}$ \\
\hline
\end{tabular}

Fonte: elaborado pela autora a partir de Walker e Jones (2012), das referências bibliográficas e dos dados empíricos coletados para o presente trabalho.

\footnotetext{
${ }^{23}$ Considerando nova categoria proposta anteriormente.

${ }^{24}$ Considerando nova subcategoria proposta anteriormente.

${ }^{25}$ Considerando nova subcategoria proposta anteriormente.

${ }^{26}$ Considerando nova categoria proposta anteriormente.

${ }^{27}$ Considerando nova categoria proposta anteriormente.

${ }^{28}$ Considerando nova subcategoria proposta anteriormente.

${ }^{29}$ Considerando nova categoria proposta anteriormente.

${ }^{30}$ Considerando nova subcategoria proposta anteriormente.

${ }_{31}^{31}$ Considerando nova subcategoria proposta anteriormente.

${ }_{32}$ Considerando nova categoria proposta anteriormente.

${ }^{33}$ Considerando nova subcategoria proposta anteriormente.
} 
E na Tabela 35 classificou-se as barreiras específicas do caso I'm Green:

Tabela 35 - Classificação das barreiras específicas do I'm Green encontradas em cada etapa

\begin{tabular}{|c|c|c|}
\hline Etapa & Barreira & Classificação \\
\hline \multirow{4}{*}{ Fase anterior } & Crise econômica & $\begin{array}{l}\text { Externa, geral }^{34} \\
\text { Nova subcategoria: crise econômica }\end{array}$ \\
\hline & $\begin{array}{l}\text { Fornecimento exclusivo de uma } \\
\text { única empresa }\end{array}$ & $\begin{array}{l}\text { Externa, fornecedor } \\
\text { Nova subcategoria: concentração de fornecimento }\end{array}$ \\
\hline & Percepção de custo mais alto & $\begin{array}{l}\text { Externa, fornecedor } \\
\text { Nova subcategoria: custo mais alto dos insumos } \\
\text { certificados }\end{array}$ \\
\hline & Custo efetivamente mais alto & $\begin{array}{l}\text { Externa, fornecedor (custo mais alto dos insumos } \\
\text { certificados) }\end{array}$ \\
\hline Fase anterior & $\begin{array}{l}\text { Alinhamento apenas com marcas } \\
\text { com apelo saudável/natural/ } \\
\text { sustentável }\end{array}$ & $\begin{array}{l}\text { Interna, questões estratégicas (marketing - definições } \\
\text { de produtos e comunicação) }\end{array}$ \\
\hline \multirow{5}{*}{ Implementação } & Custo do insumo & $\begin{array}{l}\text { Externa, fornecedor (custo mais alto dos insumos } \\
\text { certificados) }^{37}\end{array}$ \\
\hline & $\begin{array}{l}\text { Características físicas do insumo, } \\
\text { que segue sendo desenvolvido para } \\
\text { adequação a outros produtos }\end{array}$ & $\begin{array}{l}\text { Externa, fornecedor } \\
\text { Nova subcategoria: portfolio reduzido de insumos } \\
\text { certificados } \\
\text { Interna, questões funcionais (esforço de coordenação e } \\
\text { complexidade) }\end{array}$ \\
\hline & $\begin{array}{l}\text { Outros logotipos e termos } \\
\text { desenvolvidos para identificar o } \\
\text { mesmo material }\end{array}$ & $\begin{array}{l}\text { Interna, questões estratégicas (marketing - definições } \\
\text { de produtos e comunicação) } \\
\text { Externa, geral }^{30} \text { (falta de conhecimento, compreensão e }^{49} \text { valorização das cerificações) }^{41}\end{array}$ \\
\hline & $\begin{array}{l}\text { Incerteza em relação a diferenciais } \\
\text { que poderiam ser comunicados, dado } \\
\text { que insumo não seria mais exclusivo }\end{array}$ & $\begin{array}{l}\text { Interna, questões estratégicas (marketing - definições } \\
\text { de produtos e comunicação) } \\
\text { Externa, fornecedor (falta de pro-atividade na oferta de }_{\text {insumos certificados) }^{43}}\end{array}$ \\
\hline & $\begin{array}{l}\text { Negociação de contratos iniciais } \\
\text { (definição de volumes e preços) }\end{array}$ & $\begin{array}{l}\text { Externa, fornecedor (falta de pro-atividade na oferta de } \\
\text { insumos certificados) }\end{array}$ \\
\hline \multirow[t]{2}{*}{ Fase posterior } & Custo do insumo & $\begin{array}{l}\text { Externa, fornecedor (custo mais alto dos insumos } \\
\text { certificados) } \\
\text { Interna, questões estratégicas (mensuração de } \\
\text { performance - métodos contábeis tradicionais) }\end{array}$ \\
\hline & $\begin{array}{l}\text { Risco de associação de marca com } \\
\text { problemas relacionados à produção } \\
\text { de cana de açúcar }\end{array}$ & $\begin{array}{l}\text { Interna, risco de reputação } \\
\text { Nova subcategoria: conexão entre marcas }\end{array}$ \\
\hline
\end{tabular}

Fonte: elaborado pela autora a partir de Walker e Jones (2012), das referências bibliográficas e dos dados empíricos coletados para o presente trabalho.

\footnotetext{
${ }^{34}$ Considerando nova categoria proposta anteriormente.

${ }^{35}$ Considerando nova subcategoria proposta anteriormente.

${ }^{36}$ Considerando nova subcategoria proposta anteriormente.

${ }^{37}$ Considerando nova subcategoria proposta anteriormente.

${ }^{38}$ Considerando nova subcategoria proposta anteriormente.

${ }^{39}$ Considerando nova subcategoria proposta anteriormente.

${ }^{40}$ Considerando nova categoria proposta anteriormente.

${ }^{41}$ Considerando nova subcategoria proposta anteriormente..

${ }^{42}$ Considerando nova subcategoria proposta anteriormente..

${ }^{43}$ Considerando nova subcategoria proposta anteriormente.

${ }^{44}$ Considerando nova subcategoria proposta anteriormente.

${ }^{45}$ Considerando nova subcategoria proposta anteriormente.
} 
Posteriormente à esta classificação, com o objetivo de compreender a origem das barreiras comuns e distintas encontradas nos casos FSC e I'm Green, e em que fase da implementação elas mais exerciam influência, procedeu-se a análise específica das mesmas, por meio de sua consolidação. O resultado final desta análise para as barreiras comuns é apresentado na Tabela 36. Note-se que os números entre parênteses identificam o número de vezes que a barreira classificada com esta origem foi registrada. Se não há parênteses, a barreira foi citada somente uma vez.

Tabela 36 - Origem das barreiras comuns

\begin{tabular}{|c|c|}
\hline Etapa & Origem das barreiras \\
\hline Fase anterior & $\begin{array}{l}\text { Externa, geral (3) } \\
\text { Externa, fornecedor (2) } \\
\text { Externa, padronizador } \\
\text { Externa, certificador } \\
\text { Interna, questões estratégicas (2) } \\
\text { Interna, pessoas }\end{array}$ \\
\hline Implementação & Interna, questões estratégicas (2) \\
\hline Fase posterior & Externa, geral \\
\hline
\end{tabular}

Fonte: elaborado pela autora a partir de Walker e Jones (2012), das referências bibliográficas e dos dados empíricos coletados para o presente trabalho.

É possível verificar que existe uma dispersão entre as barreiras internas e externas na primeira fase, inclusive em relação às categorias, o que poderia ser esperado, dado que é momento em que as empresas estão avaliando o mercado e buscando conhecer as alternativas existentes, além de mapear as motivações internas que levariam a adoção das certificações. Com isso, há a influência de um maior número de stakeholders externos e internos no processo. No caso da fase intermediária, as questões estratégicas estão relacionadas à decisão de marketing e/ou branding sobre usar ou não o selo na embalagem dos produtos, e como divulgar isso. Por último, nota-se a barreira externa em relação à valorização da adoção da certificação por parte do mercado. O trabalho já foi realizado, a implementação já foi feita, e talvez surja uma frustração em relação aos resultados alcançados com isso, conforme proposto por Ham (2007), Piotrowski e Kratz (2005) e SustainAbility (2011), para quem as empresas se ressentem pela falta de comprovação dos benefícios da certificação. Em seguida, 
consolidou-se a origem das barreiras específicas de cada certificação, conforme apresentado na Tabela 37:

Tabela 37 - Origem das barreiras distintas

\begin{tabular}{|c|c|c|}
\hline Barreira I'm Green & Etapa & Barreira FSC \\
\hline $\begin{array}{l}\text { Externa, fornecedor ( } 3) \\
\text { Externa, geral } \\
\text { Interna, questões estratégicas }\end{array}$ & Fase anterior & $\begin{array}{l}\text { Externa, padronizador } \\
\text { Externa, fornecedor } \\
\text { Interna, integração interna } \\
\text { Interna, questões funcionais }\end{array}$ \\
\hline $\begin{array}{l}\text { Externa, fornecedor (4) } \\
\text { Externa, geral } \\
\text { Interna, questões estratégicas (2) } \\
\text { Interna, questões funcionais }\end{array}$ & Implementação & $\begin{array}{l}\text { Externa, certificador (2) } \\
\text { Externa, padronizador } \\
\text { Externa, competidores } \\
\text { Externa, fornecedor } \\
\text { Interna, questões funcionais (3) } \\
\text { Interna, questões estratégicas } \\
\text { Interna, estrutura organizacional }\end{array}$ \\
\hline $\begin{array}{l}\text { Externa, fornecedor } \\
\text { Interna, questões estratégicas } \\
\text { Interna, risco de reputação }\end{array}$ & Fase posterior & $\begin{array}{l}\text { Externa, certificador } \\
\text { Externa, padronizador } \\
\text { Interna, questões funcionais } \\
\text { Interna, questões estratégicas }\end{array}$ \\
\hline
\end{tabular}

Fonte: elaborado pela autora a partir de Walker e Jones (2012), das referências bibliográficas e dos dados empíricos coletados para o presente trabalho.

No caso do "I'm Green", as barreiras da fase anterior apresentam concentração no ambiente externo, na categoria fornecedor, o que pode ser justificado pela questão de ser uma única empresa a produzir o insumo certificado que pode carregar este selo, que foi desenvolvido por ela própria. Neste caso, não foram mapeados atores como o padronizador e o certificador, que atuam somente para certificar o processo produtivo deste fornecedor, e não foram avaliados no presente trabalho. Na fase de implementação, as barreiras já estão mais dispersas entre questões internas (referentes a questões de marketing e de adaptação às propriedades físicas do insumo), e externas (referentes a custos e à oferta dos insumos de maneira mais proativa). Para o FSC, as barreiras externas são mais dispersas entre os diversos atores da execução da certificação, dado que as empresas convertedoras devem ser certificadas e, em alguns casos, as próprias empresas de bens de consumo. Pode-se verificar, também, que há maior concentração de barreiras específicas FSC na etapa de implementação, devido ao esforço que deve ser feito em relação a adaptações necessárias, preparação de documentos, treinamentos internos, dentre outros. 
A comparação entre os casos abre espaço para outras reflexões, como a questão das tecnologias envolvidas. Foi levantado que as negociações com fornecedores foram um pouco mais trabalhosas no caso "I'Green", e isso poderia sugerir que fornecedores que precisam processar os materiais para transformá-los em embalagem teriam maior resistência a adotar novas tecnologias. No caso da embalagem de papel, o fornecedor compra a chapa de papel certificado pronto e coloca em máquina para fazer impressão, corte etc. Já em relação ao plástico, o mesmo deve ser derretido para depois ser inserido num molde, que dará a forma da embalagem final. Esta questão de colocar o novo material dentro de um molde gera receio de que o mesmo estrague.

Em relação às áreas envolvidas, pôde-se levantar que são quatro as mais envolvidas, tendo sido citadas por todas as empresas em ambos os casos: produção, projetos, suprimentos e marketing e/ou comercial. No caso "I'm Green", todas as empresas que o implementaram também citaram a área de inovação, mas ela não foi unanimidade entre as empresas que adotaram o FSC. O mesmo aconteceu com a área comercial, mas de forma inversa: todas as empresas que implementaram o FSC a citaram, tendo sido mencionada por apenas uma que implementou o "I'm Green". As demais diferenças podem ser visualizadas na Tabela 38.

Tabela 38 - Consolidação: principais atores envolvidos na implementação das certificações

\begin{tabular}{|c|c|c|}
\hline & I'm Green & FSC \\
\hline $\begin{array}{l}\text { Citados por } \\
\text { todas as } \\
\text { empresas }\end{array}$ & $\begin{array}{l}\text { - Áreas internas: } \\
\text { Produção } \\
\text { Inovação (pesquisa avançada) } \\
\text { Projetos } \\
\text { Suprimentos } \\
\text { Marketing } \\
\text { - Stakeholders: } \\
\text { Fornecedor de insumos }\end{array}$ & $\begin{array}{l}\text { - Áreas internas: } \\
\text { Produção } \\
\text { Projetos } \\
\text { Suprimentos } \\
\text { Marketing e/ou comercial } \\
\text { - Stakeholders: } \\
\text { Fornecedor de insumos } \\
\text { Certificadora }\end{array}$ \\
\hline $\begin{array}{l}\text { Específicos de } \\
\text { uma empresa }\end{array}$ & $\begin{array}{l}\text { - Áreas internas: } \\
\text { Meio-ambiente } \\
\text { Sustentabilidade } \\
\text { Comunicação } \\
\text { Comercial } \\
\text { Técnica } \\
\text { Diretoria }\end{array}$ & $\begin{array}{l}\text { - Áreas internas: } \\
\text { Meio-ambiente } \\
\text { Sistemas de gestão (inclui auditoria e } \\
\text { qualidade) } \\
\text { Faturamento } \\
\text { Transporte } \\
\text { Inovação (pesquisa avançada) } \\
\text { Diretoria } \\
\text { Novas tecnologias } \\
\text {-Stakeholders: } \\
\text { Parceiros comerciais }\end{array}$ \\
\hline
\end{tabular}




\subsection{Outras barreiras levantadas}

Durante a realização das entrevistas foi possível levantar algumas outras barreiras à certificação sustentável que não estavam relacionadas especificamente ao caso FSC ou I'm Green, mas que considerou-se interessante registrar para que também seja possível comparálas com as barreiras levantadas na revisão bibliográfica. Como exemplo, pode citar a fala de Elaine Cristina, da Mazurky:

[...] a cultura brasileira infelizmente é uma cultura muito retroativa na parte de sustentabilidade. Embora fale-se muito na mídia, não se explica o que é, como agir, como fazer, então as pessoas escutam, muitas vezes falam, mas não sabem ao certo.

Esta questão de que o consumidor brasileiro não valoriza atitudes socioambientais das empresas já foi referenciada anteriormente por Voltolini (2010), mas não havia sido considerada uma barreira ao uso das certificações sustentáveis por nenhum outro autor. Ela foi citada por todos os entrevistados, que mencionavam, além da cultura, outras possíveis justificativas, como o baixo nível educacional ou de renda, cujo principal direcionador no momento da compra é o preço. A seguir são apresentados trechos de alguns entrevistados em que o tema é comentado:

[...] Eu acho que assim, quando eu vejo o mercado tipo a Inglaterra, por exemplo, eu vejo que algumas coisas lá fazem mais sentido, as pessoas entendem um pouco melhor. Aqui eu acho que menos e eu acho que no Brasil, até a gente brinca um pouco que as pessoas querem ser sustentáveis só que elas querem que você faça o trabalho por elas, ou seja, as pessoas não querem pagar mais ou ter que ter algum tipo de desconforto, né, então sempre que em pesquisa você fala "olha, eu tenho isso aqui que é uma embalagem mais sustentável... ah e vai custar 3\% mais caro, né, as pessoas tendem a rejeitar. (Entrevistado Y)

[...] Então é claro que essa dinâmica no Brasil é diferente, né (...) existem pesquisas que avaliam os aspectos influenciadores da decisão de compra do brasileiro (...), alguns desses estudos indicam que primeiro vem o preço, e depois outros aspectos do produto como qualidade e alegações socioambientais. Tem relação também com o poder de compra das pessoas, e o quanto aquilo faz sentido na vida da pessoa "eu tô aqui lutando pra sobreviver" ou "eu tô aqui lutando pra arrumar um emprego" (...) essas coisas (de rotulagem sustentável) podem parecer sofisticadas demais. Em algumas sociedades mais conscientes, ou com os problemas de base mais equacionados, a mecânica da certificação funciona melhor, e tem-se consumidores mais dispostos a privilegiar produtos com garantias socioambientais vinculadas. (Daniele Rua, Imaflora)

[...] No Brasil o consumidor não valoriza o selo, porque acho que ele nem entende. Na hora que você faz uma pesquisa e pergunta "você ta disposto a pagar mais, por exemplo, por isso"? Ele fala "sim", isso é super legal, mas na real ele não vai pagar mais. Na hora que ele 
vai pro supermercado ele vai olhar o preço, então não acho que a consciência está nesse nível no Brasil.... é um percentual muito, muito pequeno ainda. (Flavia Bartholomeu, Natura)

Luis Martini, da BoxPrint, também cita questões culturais, mas estas relacionadas à cultura empresarial brasileira que, segundo ele, "prioriza comunicar mais questões e valores internos do que princípios de sustentabilidade". O executivo disse ficar decepcionado ao oferecer produtos sustentáveis e não obter retorno por parte de seus clientes. Claudia Cappra comenta que o número de empresas brasileiras que usam o selo "I'm Green" ainda é baixo, pois:

[...] No Brasil, por uma questão de mercado, né, é maturidade de mercado. Só as grandes empresas, empresas que tem conceitos sustentáveis muito fortes que estão seguindo essa linha, mas ainda é muito incipiente no país. Na Europa é completamente diferente. Isso já está dentro do DNA das empresas. Eu acho que é o perfil de mercado. É um mercado muito diferente lá fora, muito diferente. As empresas tem premissas sustentáveis muito diferentes ainda.

O entrevistado Pedro Dameto, da Flape, também comenta que a cultura da maioria das empresas é muito voltada somente para o lucro, sendo que novidades sustentáveis, se não trouxerem ganhos financeiros, dificilmente são adotadas, o que é corroborado por Fabiola Zerbini, do FSC:

[...] Acho que a primeira barreira é a questão da decisão política, da empresa investir em qualidade social e ambiental. Eu sou muito cética em relação ao pilar ambiental e social da sustentabilidade, eles estão dentro de uma empresa radicalmente condicionados ao pilar econômico, né, então não venha dizer o contrário que é mentira! Se houver uma justificativa econômica, a empresa vai adotar melhores práticas, e se ela precisar economicamente justificar ou demonstrar ou explicitar isso, ela vai se certificar. Essa motivação econômica é natural desse processo, então se não houver motivação econômica, esquece, que a certificação não vai acontecer.

Uma outra questão bastante citada foi a do número de apelos sustentáveis existentes, que causa um problema tanto para as empresas, no momento em que estão avaliando as opções disponíveis, quanto para os consumidores, que não conseguem reconhecer todos os apelos que estão sendo feitos, nem compreender as mensagens que estão sendo transmitidas. Esta questão já foi levantado por diversos autores (Brécard, 2014; Gallastegui, 2002; J. Morris, 1997; 
Ottman et al., 2006; Piotrowski \& Kratz, 2005; Roberts, 1996). Isto pode ser verificado na fala de Flavia Bartholomeu, da Natura:

[...] Mas é que existe tantos, eu não acho que eles estão sendo efetivos porque tem muitos e cada um tem um racional de cálculo, então cada um considera uma coisa, então é difícil você tomar partido e falar "esse é melhor do que aquele" porque eles, simplesmente, eles são diferentes. E não existe uma norma internacional que fala na hora que você vai falar de carbono na sua embalagem "o calculo é esse e a forma que você tem que mostrar é essa". Isso ajudaria o consumidor porque você olha um monte de selo e não adianta você enfiar um monte de selo na sua embalagem que vai falar "parece que é bom" e não necessariamente é melhor do que um outro que tem um só, porque o racional de calculo pode ser muito distinto e depende do que você está avaliando e a sustentabilidade ela também é local, depende de onde você está. E eu acho que também que tem muita empresa que simplesmente coloca e não tem um racional e uma política clara. Pára então! Não sei se eu confio tanto nos selos... ou todos.

O fato de algumas empresas usarem um apelo sustentável sem ter um racional que o suporte (maquiagem verde) a fim obter um diferencial de forma enganosa também foi identificado na entrevista com Fabíola Zerbini, do FSC:

[...] eu falei que tá mudando, mas tá mudando de uma situação muito ruim pra uma situação menos pior. Ainda existe uma grande confusão por parte dos consumidores e muitas delas quase que intencionais, né, pra... muitas marcas, muitos selos que usam e fazem uso dessa ignorância (do consumidor).

A opinião de Edson Futino, da L’Occitane, está em linha com a de Flavia Bartholomeu, no que se refere às diferentes formas de cálculo de impactos existentes. Segundo ele,

[...] falta uma certificação oficial no Brasil, ou uma "calculadora pra sustentabilidade" que fosse padrão para todas as empresas (...) para que fosse viável fazer comparações (...) cada empresa acaba adotando a sua política de sustentabilidade e foca naquilo (que tem de melhor) pra poder expor o seu programa sustentável para a comunidade.

Para Raquel Badia, da Natura, a questão da certificação talvez seja substituída pelo conceito de transparência radical, que é uma tendência relacionada à exposição total da sua cadeia de produção, o que acaba por fortalecer a credibilidade da marca e, com isso, a necessidade de se contar com esquemas que precisam da validação de terceira parte cai por terra. Segundo ela, 
[...] as empresas mostram as evidências, e se mostram mais humanas... "erramos, mesmo, na marca tal - o suco saiu contaminado, mesmo, pedimos desculpas". Eu acho que mostra um lado humano e uma vontade de acertar, e eu acho que é isso que as pessoas vão buscar, muito mais do que o selo. Pra mim as as marcas ficam cada vez mais fortes.

Resultante da quantidade de certificações no mercado, ou de uma cultura que não valoriza as questões sustentáveis, uma outra questão levantada se refere à falta de conhecimento pelos próprios executivos entrevistados das diversas certificações existentes, sendo que grande parte dos entrevistados não souberam citar outras certificações além daquelas das quais faziam uso. Outro problema se refere ao desconhecimento do significado e/ou confusão em relação às certificações, como pode ser verificado na fala do entrevistado X:

[...] Paralelo ao FSC, existe o Cerflor. O Cerflor, ele é uma certificação FSC, porém com origem diferente. O Cerflor ela é Greenpeace, uma ONG. O propósito é o mesmo, porém existe só, vamos dizer assim, a diferença da iniciativa de origem disso. O FSC surgiu a partir de iniciativa da indústria ${ }^{46}$.

Devido a falta de reconhecimento das certificações por parte dos consumidores, o entrevistado $\mathrm{Y}$ sugere que as campanhas de comunicação de marketing com apelos relacionados a certificação sustentável não geram tanto resultado quanto outros tipos de comunicação, sendo esse um grande desafio para conseguir priorizar estas campanhas. Segundo ele, "[...] você não tem um dinheiro infinito, então ou você comunica sua mensagem de marca ou você comunica o selo e aí no momento que você está com o orçamento apertado, você vai comunicar a sua mensagem, a sua promoção". Para o executivo, uma iniciativa que certamente daria mais resultado seria se os grandes varejistas começassem a oferecer benefícios para empresas e produtos certificados: "Se um Grupo Pão de Açúcar abraçar e falar 'ah, eu vou dar um espaço especial pra produtos que tem esse selo'... é outra história, né?’.

O entrevistado Y comenta, ainda, que alguns selos podem, inclusive, gerar algum tipo de estranhamento, e confundir mais o consumidor, em vez de apoiá-lo no momento da compra. $\mathrm{O}$ executivo cita o Rainforest Alliance, cujo logotipo é a imagem de um sapinho: "a pessoa vai olhar um sapo na embalagem de alimento, e talvez a primeira associação não seja tão boa.

\footnotetext{
${ }^{46}$ A origem do FSC já foi apresentada no tópico 4.1 do presente trabalho. O Cerflor é uma certificação de manejo florestal administrada pelo INMETRO.
} 
Poucas pessoas vão olhar o verso da embalagem para entender melhor”. Uma última barreira a ser apresentada se refere à atuação por parte do Governo:

[...] temos vários projetos voltados para área sustentável, mas que a gente muitas vezes não consegue levar todos adiante porque a gente não tem assim, incentivos fiscais, incentivos do governo, infelizmente o empresário que tenta adotar alguma coisa da parte sustentável, ele encontra grandes barreiras. (Elaine Cristina, Mazurky)

A consolidação das barreiras apresentadas neste tópico, assim como sua classificação, de acordo com o modelo de Walker e Jones (2012) são apresentadas na Tabela 39, a seguir. Vale ressaltar que as novas categorias e subcategorias propostas no tópico anterior (4.4) já serão utilizadas neste exercício de classificação.

Tabela 39 - Consolidação e classificação das outras barreiras levantadas na pesquisa (continua)

\begin{tabular}{|c|c|c|}
\hline Barreira & Descrição & Classificação \\
\hline Cultura brasileira & $\begin{array}{l}\text { Consumidor brasileiro não valoriza atitudes } \\
\text { socioambientais das empresas, seja por } \\
\text { questões culturais, de nível educacional ou } \\
\text { de renda } \\
\text { Empresas brasileiras não tem cultura } \\
\text { voltada para sustentabilidade; aspectos } \\
\text { econômicos sobressaem no momento das } \\
\text { decisões }\end{array}$ & $\begin{array}{l}\text { Externa, geral } \\
\text { Nova subcategoria: aspectos } \\
\text { culturais }\end{array}$ \\
\hline $\begin{array}{l}\text { Diversas } \\
\text { certificações } \\
\text { existentes no } \\
\text { mercado }\end{array}$ & $\begin{array}{l}\text { Falta de padronização e/ou estabelecimento } \\
\text { de requisitos mínimos pelo governo ou } \\
\text { órgãos competentes. } \\
\text { As diferentes formas de cálculo gera } \\
\text { dificuldade de se estabelecer comparações } \\
\text { Consumidores não compreendem } \\
\text { mensagens } \\
\text { Maquiagem verde }\end{array}$ & $\begin{array}{l}\text { Externa, governo (regulamentação) } \\
\text { Externa, padronizador } \\
\text { Nova subcategoria: número de } \\
\text { esquemas existentes } \\
\text { Externa, geral (falta de } \\
\text { conhecimento, compreensão e } \\
\text { valorização das certificações) } \\
\text { Externa, competidores (maquiagem } \\
\text { verde) }\end{array}$ \\
\hline $\begin{array}{l}\text { Falta atuação dos } \\
\text { varejistas }\end{array}$ & $\begin{array}{l}\text { Falta de valorização e incentivo às } \\
\text { certificações por parte dos varejistas }\end{array}$ & $\begin{array}{l}\text { Nova categoria: varejo } \\
\text { Nova subcategoria: falta de } \\
\text { valorização e incentivo por parte } \\
\text { dos varejistas }\end{array}$ \\
\hline $\begin{array}{l}\text { Competição } \\
\text { entre mensagens } \\
\text { do produto a } \\
\text { serem } \\
\text { comunicadas }\end{array}$ & $\begin{array}{l}\text { Um único produto tem diversos atributos, e } \\
\text { os recursos para comunica-los são } \\
\text { limitados (tempo, espaço, investimento } \\
\text { financeiro), sendo que as certificações são } \\
\text { preteridas no momento da escolha de qual } \\
\text { atributo será priorizado }\end{array}$ & $\begin{array}{l}\text { Interna, questões funcionais } \\
\text { (marketing - definições de produtos } \\
\text { e comunicação") }\end{array}$ \\
\hline
\end{tabular}


(conclusão)

\begin{tabular}{l|l|l}
\hline Barreira & Descrição & Classificação \\
\hline $\begin{array}{l}\text { Falta de } \\
\text { incentivos por } \\
\text { parte do Governo }\end{array}$ & $\begin{array}{l}\text { Falta de incentivos por parte do Governo } \\
\text { para iniciativas privadas relacionadas à } \\
\text { sustentabilidade }\end{array}$ & $\begin{array}{l}\text { Externa, governo } \\
\text { Nova subcategoria: falta de } \\
\text { incentivos }\end{array}$ \\
\hline $\begin{array}{l}\text { Estranhamento } \\
\text { causado por } \\
\text { certas } \\
\text { certificações }\end{array}$ & $\begin{array}{l}\text { Algumas certificações são representadas } \\
\text { por meio de logotipos que podem trazer } \\
\text { mensagens dúbias ou “estranhas" }\end{array}$ & $\begin{array}{l}\text { Externa, padronizador } \\
\text { Nova subcategoria: imagem de } \\
\text { marca }\end{array}$ \\
\hline $\begin{array}{l}\text { Tendência de } \\
\text { transparência } \\
\text { radical }\end{array}$ & $\begin{array}{l}\text { Certificações não seriam mais necessárias } \\
\text { pois marcas seriam cada vez mais } \\
\text { transparentes e, consequentemente, críveis } \\
\text { e fortes; com isso, não haveria mais } \\
\text { necessidade de se obter comprovações de } \\
\text { apelos realizadas por terceiros }\end{array}$ & $\begin{array}{l}\text { Nova subcategoria: tendência de } \\
\text { transparência radical }\end{array}$ \\
\hline
\end{tabular}

Fonte: elaborado pela autora a partir de Walker e Jones (2012), das referências bibliográficas e dos dados empíricos coletados para o presente trabalho.

\subsection{Consolidação final das barreiras e proposta de modelo conceitual}

Para finalizar a análise a respeito das barreiras às certificações sustentáveis, primeiro foi realizada a classificação das barreiras levantadas na revisão bibliográfica segundo o modelo de Walker e Jones (2012), assim como foi feito com as barreiras levantadas nos casos, conforme descrito no tópico 4.4. Importante ressaltar que as novas categorias e subcategorias propostas no referido tópico já foram consideradas nesta classificação, conforme pode ser visualizado na Tabela 40.

Tabela 40 - Classificação das barreiras levantadas na revisão bibliográfica

(continua)

\begin{tabular}{l|l|l|l}
\hline Barreira & Descrição & Classificação \\
\hline 1 & $\begin{array}{l}\text { Aumento de } \\
\text { custos }\end{array}$ & $\begin{array}{l}\text { Pode haver um investimento inicial para } \\
\text { realizar as certificações, além de } \\
\text { investimentos periódicos para manutenção } \\
\text { das mesmas; } \\
\text { Empresas eventualmente devem fazer } \\
\text { adaptações em seus processos internos para } \\
\text { se prepararem para certificação; } \\
\text { Custo de insumos certificados pode ser } \\
\text { maior que de insumos sem certificação. }\end{array}$ & $\begin{array}{l}\text { Interna, questão estrate } \\
\text { (limitação de recursos) }\end{array}$ \\
\hline
\end{tabular}


(continuação)

\begin{tabular}{|c|c|c|c|}
\hline & Barreira & Descrição & Classificação \\
\hline 2 & $\begin{array}{l}\text { Prazos para } \\
\text { adequar } \\
\text { processos e } \\
\text { realizar a } \\
\text { certificação }\end{array}$ & $\begin{array}{l}\text { Processo de adequação a padrões pode ser } \\
\text { muito longo, desestimulando } \\
\text { colaboradores. }\end{array}$ & $\begin{array}{l}\text { Interna, questão funcional } \\
\text { Nova subcategoria: prazos para } \\
\text { obter certificação }\end{array}$ \\
\hline 3 & $\begin{array}{l}\text { Nível dos } \\
\text { padrões }\end{array}$ & $\begin{array}{l}\text { Revisões nos critérios são constantes; } \\
\text { Exigências muito altas acabam excluindo, } \\
\text { de forma não intencional, a maioria dos } \\
\text { produtores. } \\
\text { Se critérios são muito baixos, fica difícil } \\
\text { buscar diferenciação. }\end{array}$ & $\begin{array}{l}\text { Externa, padronizador (critérios da } \\
\text { padronização) }\end{array}$ \\
\hline 4 & $\begin{array}{l}\text { Imprevisibilidade } \\
\text { da demanda para } \\
\text { produtos } \\
\text { certificados }\end{array}$ & $\begin{array}{l}\text { Muito se fala sobre o aumento da demanda } \\
\text { por produtos sustentáveis, mas na prática } \\
\text { empresários ainda não captaram essa } \\
\text { tendência e/ou não conseguiram mensurar } \\
\text { este potencial; } \\
\text { Lacuna entre discurso ambientalmente } \\
\text { correto por parte de consumidores versus } \\
\text { sua prática no momento da compra; } \\
\text { Falta conhecimento sobre como } \\
\text { consumidores reconhecem e interpretam as } \\
\text { certificações; } \\
\text { Produtos podem não atender a expectativa } \\
\text { dos consumidores em relação ao preço, } \\
\text { performance ou qualidade. }\end{array}$ & $\begin{array}{l}\text { Externa, consumidores } \\
\text { Nova categoria: lacuna entre } \\
\text { discurso e prática }\end{array}$ \\
\hline 5 & $\begin{array}{l}\text { Diversas } \\
\text { certificações } \\
\text { existentes no } \\
\text { mercado }\end{array}$ & $\begin{array}{l}\text { Sobreposição de padrões, dificuldade para } \\
\text { diferenciá-los, falta de informações sobre } \\
\text { cada um; } \\
\text { Incertezas relacionadas a oferta e } \\
\text { credibilidade de diversas padronizadoras e } \\
\text { certificadoras, não só entre as empresas, } \\
\text { mas perante outros stakeholders; } \\
\text { "Penalização" para empresas com maior } \\
\text { comprometimento, devido à confusão } \\
\text { causada pelo grande número de apelos } \\
\text { sustentáveis; } \\
\text { Incertezas em relação ao nível de } \\
\text { compreensão e valorização por parte dos } \\
\text { consumidores. }\end{array}$ & $\begin{array}{l}\text { Externa, padronizador } \\
\text { Nova subcategoria: número de } \\
\text { esquemas existentes }\end{array}$ \\
\hline 6 & $\begin{array}{l}\text { Maquiagem } \\
\text { verde }\end{array}$ & $\begin{array}{l}\text { Apelos sustentáveis perderam credibilidade } \\
\text { com o passar do tempo devido a quantidade } \\
\text { de apelos inseridos no mercado sem a } \\
\text { devida contrapartida por parte da empresa. }\end{array}$ & $\begin{array}{l}\text { Externa, competidores } \\
\text { Nova categoria: maquiagem verde }\end{array}$ \\
\hline
\end{tabular}

\footnotetext{
${ }^{47}$ Podem ser muito rígidos, muito frouxos ou ter revisões constantes.
} 
(continuação)

\begin{tabular}{|c|c|c|c|}
\hline & Barreira & Descrição & Classificação \\
\hline 7 & $\begin{array}{l}\text { Falta de } \\
\text { ferramentas e } \\
\text { consequente } \\
\text { dificuldade para } \\
\text { mensurar } \\
\text { impactos }\end{array}$ & $\begin{array}{l}\text { Incerteza em relação aos impactos efetivos } \\
\text { da certificação no meio ambiente e/ou na } \\
\text { sociedade; } \\
\text { Falta de bancos de dados e informações; } \\
\text { Falta de garantias sobre informações } \\
\text { disponíveis; } \\
\text { Dificuldade em saber quais são os melhores } \\
\text { materiais disponíveis. }\end{array}$ & $\begin{array}{l}\text { Externa, padronizador } \\
\text { Nova subcategoria: falta de } \\
\text { ferramentas para mensurar } \\
\text { impactos }\end{array}$ \\
\hline 8 & $\begin{array}{l}\text { Falta de } \\
\text { comprovação dos } \\
\text { benefícios da } \\
\text { certificação }\end{array}$ & $\begin{array}{l}\text { Indagação se investimentos necessários são } \\
\text { compensados. }\end{array}$ & $\begin{array}{l}\text { Internas, questões estratégicas } \\
\text { (mensuração de performance por } \\
\text { meio de métodos contábeis } \\
\text { tradicionais) }\end{array}$ \\
\hline 9 & $\begin{array}{l}\text { Processo de } \\
\text { definição de } \\
\text { critérios e/ou } \\
\text { mensuração das } \\
\text { certificações }\end{array}$ & $\begin{array}{l}\text { Critérios definidos com base em interesses } \\
\text { próprios, baseados em percepções ou } \\
\text { questões políticas, não em ciência; } \\
\text { Não há uma metodologia definitiva aceita } \\
\text { pelos diversos stakeholders envolvidos no } \\
\text { processo; } \\
\text { Dificuldades em se comparar ciclos de vida } \\
\text { de produtos tão diferentes; } \\
\text { Padrões muito dominados pelos grupos de } \\
\text { interesse e/ou suscetíveis aos mesmos; } \\
\text { Falta de transparência por parte das } \\
\text { certificadoras e/ou padronizadoras. }\end{array}$ & $\begin{array}{l}\text { Externa, padronizador } \\
\text { (transparência na definiçãa de } \\
\text { critérios) } \\
\text { Nova subcategoria: envolvimento } \\
\text { de stakeholders no processo }\end{array}$ \\
\hline 10 & $\begin{array}{l}\text { Aumento da } \\
\text { complexidade da } \\
\text { cadeia de } \\
\text { custódia com } \\
\text { aumento da } \\
\text { globalização }\end{array}$ & $\begin{array}{l}\text { Dificuldade de se estabelecer padrões que } \\
\text { sejam relevantes globalmente, dado que } \\
\text { cada região tem prioridades ambientais } \\
\text { diferentes; } \\
\text { Dificuldade de mensurar impactos com } \\
\text { fornecimento sendo realizados a partir de } \\
\text { diversas regiões; } \\
\text { Descentralização de operações das } \\
\text { empresas, o que amplia carteira de } \\
\text { fornecedores e abre espaço para sub- } \\
\text { contratações, o que dificulta a } \\
\text { rastreabilidade; } \\
\text { Produtores de países em desenvolvimento } \\
\text { podem enfrentar dificuldades de entrada em } \\
\text { países desenvolvidos; } \\
\text { Regras estabelecidas em acordos } \\
\text { internacionais de comércio. }\end{array}$ & $\begin{array}{l}\text { Externa, global (necessidade de se } \\
\text { definir se fornecimento deve ser } \\
\text { local ou global) } \\
\text { Nova subcategoria: diferenças entre } \\
\text { prioridades socioambientais de cada } \\
\text { região } \\
\text { Nova subcategoria: } \\
\text { descentralização da produção } \\
\text { dificulta rastreabilidade }\end{array}$ \\
\hline
\end{tabular}


(continuação)

\begin{tabular}{|c|c|c|c|}
\hline & Barreira & Descrição & Classificação \\
\hline 11 & Escala & $\begin{array}{l}\text { Tamanho e capacidade das padronizadoras } \\
\text { e certificadoras; } \\
\text { Muitos esquemas ainda são de nicho, não } \\
\text { tendo escala necessária para atender } \\
\text { grandes empresas. }\end{array}$ & $\begin{array}{l}\text { Externa, padronizador } \\
\text { Nova subcategoria: escala e } \\
\text { abrangência } \\
\text { Externa, certificador } \\
\text { Nova subcategoria: escala e } \\
\text { abrangência }\end{array}$ \\
\hline 12 & $\begin{array}{l}\text { Design das } \\
\text { embalagens }\end{array}$ & $\begin{array}{l}\text { Falta de espaço na embalagem para } \\
\text { comunicar certificação; } \\
\text { Designers que não querem colocar a } \\
\text { certificação em suas peças criativas. }\end{array}$ & $\begin{array}{l}\text { Internas, questões funcionais } \\
\text { (marketing - definições de produtos } \\
\text { e comunicação) }\end{array}$ \\
\hline 13 & $\begin{array}{l}\text { Incerteza em } \\
\text { relação ao futuro }\end{array}$ & $\begin{array}{l}\text { Dúvidas sobre aumento ou não da demanda } \\
\text { por certificações; } \\
\text { Dúvidas sobre como papel das certificações } \\
\text { vai se desenvolver. }\end{array}$ & $\begin{array}{l}\text { Externa, geral } \\
\text { Nova subcategoria: incertezas em } \\
\text { relação ao futuro do mercado de } \\
\text { certificações }\end{array}$ \\
\hline 14 & Inibe inovação & $\begin{array}{l}\text { Para atender requisitos empresas acabam } \\
\text { não investindo em melhorias nos produtos } \\
\text { certificados. }\end{array}$ & $\begin{array}{l}\text { Externa, padronizador } \\
\text { Nova subcategoria: não contempla } \\
\text { critérios relacionados à inovação }\end{array}$ \\
\hline 15 & $\begin{array}{l}\text { Conexão entre } \\
\text { marcas (da } \\
\text { empresa e da } \\
\text { padronizadora) }\end{array}$ & $\begin{array}{l}\text { Se houver algum problema com a } \\
\text { padronizadora, a marca da empresa também } \\
\text { poderá ser afetada. }\end{array}$ & $\begin{array}{l}\text { Interna, risco de reputação } \\
\text { Nova subcategoria: conexão entre } \\
\text { marcas (co-branding) }\end{array}$ \\
\hline 16 & $\begin{array}{l}\text { Esforço de } \\
\text { coordenação e } \\
\text { complexidade }\end{array}$ & $\begin{array}{l}\text { Demanda por muitas informações; } \\
\text { Necessidade de realização de auditorias e } \\
\text { treinamentos internos; } \\
\text { Complexidade das operações realizadas; } \\
\text { Necessidade de disponibilizar tempo dos } \\
\text { colaboradores para auxiliar na implantação; } \\
\text { Diversos documentos (oficiais ou não) com } \\
\text { orientações de como fazer uso de } \\
\text { comunicações sustentáveis; } \\
\text { Exigências em relação à aplicações das } \\
\text { marcas. }\end{array}$ & $\begin{array}{l}\text { Interna, questões funcionais } \\
\text { (esforço de coordenação e } \\
\text { complexidade) }\end{array}$ \\
\hline 17 & $\begin{array}{l}\text { Estrutura } \\
\text { organizacional } \\
\text { das empresas }\end{array}$ & $\begin{array}{l}\text { Estrutura não preparada para lidar com } \\
\text { certificações sustentáveis; } \\
\text { Necessidade de a alta gestão ser mais } \\
\text { envolvida com o tema; } \\
\text { Baixa escolaridade de colaboradores, } \\
\text { dificuldades em mexer nas ferramentas. }\end{array}$ & $\begin{array}{l}\text { Interna, questões funcionais } \\
\text { (estrutura organizacional) }\end{array}$ \\
\hline
\end{tabular}


(conclusão)

\begin{tabular}{|c|c|c|c|}
\hline & Barreira & Descrição & Classificação \\
\hline 18 & $\begin{array}{l}\text { Problemas de } \\
\text { fornecimento }\end{array}$ & $\begin{array}{l}\text { Não encontra fornecedores que tenham } \\
\text { certificação; } \\
\text { No caso de matérias primas, limita } \\
\text { flexibilidade de fornecimento para poucos } \\
\text { fornecedores certificados; } \\
\text { Não conseguem obter informações de toda } \\
\text { a cadeia de fornecimento. }\end{array}$ & $\begin{array}{l}\text { Externa, fornecedores (baixo } \\
\text { envolvimento) } \\
\text { Nova subcategoria: falta de } \\
\text { fornecedores certificados } \\
\text { Nova subcategoria: concentração de } \\
\text { fornecimento }\end{array}$ \\
\hline 19 & $\begin{array}{l}\text { Falta de } \\
\text { reconhecimento } \\
\text { e valorização }\end{array}$ & $\begin{array}{l}\text { Certificações não são consideradas como } \\
\text { fator de decisão de compra } \\
\text { A adoção de certificações não é valorizada } \\
\text { pelos stakeholders }\end{array}$ & $\begin{array}{l}\text { Externa, geral (falta de } \\
\text { conhecimento, compreensão e } \\
\text { valorização das certificações) }\end{array}$ \\
\hline 20 & $\begin{array}{l}\text { Falta de maior } \\
\text { posicionamento } \\
\text { do poder público }\end{array}$ & $\begin{array}{l}\text { Governo poderia desenvolver e/ou } \\
\text { identificar padrões que fossem oficiais, a } \\
\text { fim de orientar melhor empresas e } \\
\text { consumidores, e limitando a proliferação de } \\
\text { certificações } \\
\text { Governo poderia inserir certificações como } \\
\text { requisitos de compras públicas }\end{array}$ & Externa, Governo (regulamentação) \\
\hline
\end{tabular}

Fonte: Elaborado pela autora a partir da revisão bibliográfica e de Walker e Jones (2012).

Em seguida, foi feita uma comparação entre as barreiras levantadas na revisão bibliográfica e as que foram citadas nos casos, a fim de avaliar a aderência das mesmas, e posteriormente consolidar uma listagem única de barreiras, conforme apresentado na Tabela 41. Note-se que na terceira coluna é realizada uma verificação se aquela barreira foi ou não citada na análise dos casos e, posteriormente, se necessário, é feita uma nova proposta de descrição da barreira (coluna 4 - descrição final), para que ela fique em linha com os novos achados da presente pesquisa. Note-se que as alterações foram sublinhadas para facilitar a sua identificação. Após consolidação e ajustes das barreiras que já haviam sido listadas anteriormente, inseriu-se as novas barreiras que foram levantadas na pesquisa empírica ao final da tabela 41, com sua respectiva proposta de descrição. 
Tabela 41 - Consolidação das barreiras às certificações sustentáveis

(continua)

\begin{tabular}{|c|c|c|c|}
\hline & Barreira & Citada no caso? & Descrição final \\
\hline 1 & Aumento de custos & $\begin{array}{l}\text { Sim } \\
\text { Sem necessidade } \\
\text { de alterar texto } \\
\text { final }\end{array}$ & $\begin{array}{l}\text { Pode haver um investimento inicial para realizar as } \\
\text { certificações, além de investimentos periódicos para } \\
\text { manutenção das mesmas; } \\
\text { Empresas eventualmente devem fazer adaptações em } \\
\text { seus processos internos para se prepararem para } \\
\text { certificação; } \\
\text { Custo de insumos certificados pode ser maior que de } \\
\text { insumos sem certificação. }\end{array}$ \\
\hline 2 & $\begin{array}{l}\text { Prazos para adequar } \\
\text { processos e realizar a } \\
\text { certificação }\end{array}$ & Não & $\begin{array}{l}\text { Processo de adequação a padrões pode ser muito } \\
\text { longo, desestimulando colaboradores. }\end{array}$ \\
\hline 3 & Nível dos padrões & $\begin{array}{l}\text { Sim } \\
\text { Proposta de } \\
\text { alteração de texto }\end{array}$ & $\begin{array}{l}\text { Revisões nos critérios são constantes; } \\
\text { Exigências muito altas acabam excluindo, de forma } \\
\text { não intencional, a maioria dos produtores; } \\
\text { Se critérios são muito baixos, fica difícil buscar } \\
\text { diferenciação; } \\
\text { Gestão de logomarca da certificação dificulta } \\
\text { processos internos das empresas. }\end{array}$ \\
\hline 4 & $\begin{array}{l}\text { Imprevisibilidade da } \\
\text { demanda para produtos } \\
\text { certificados }\end{array}$ & $\begin{array}{l}\text { Sim } \\
\text { Sem necessidade } \\
\text { de alterar texto } \\
\text { final }\end{array}$ & $\begin{array}{l}\text { Muito se fala sobre o aumento da demanda por } \\
\text { produtos sustentáveis, mas na prática empresários } \\
\text { ainda não captaram essa tendência e/ou não } \\
\text { conseguiram mensurar este potencial; } \\
\text { Lacuna entre discurso ambientalmente correto por } \\
\text { parte de consumidores versus sua prática no momento } \\
\text { da compra; } \\
\text { Falta conhecimento sobre como consumidores } \\
\text { reconhecem e interpretam as certificações; } \\
\text { Produtos podem não atender a expectativa dos } \\
\text { consumidores em relação ao preço, performance ou } \\
\text { qualidade. }\end{array}$ \\
\hline
\end{tabular}


(continuação)

\begin{tabular}{|c|c|c|c|}
\hline & Barreira & Citada no caso? & Descrição final \\
\hline 5 & $\begin{array}{l}\text { Diversas certificações } \\
\text { existentes no mercado }\end{array}$ & $\begin{array}{l}\text { Sim } \\
\text { Sem necessidade } \\
\text { de alterar texto } \\
\text { final }\end{array}$ & $\begin{array}{l}\text { Sobreposição de padrões, dificuldade para diferenciá- } \\
\text { los, falta de informações sobre cada um; } \\
\text { Incertezas relacionadas a oferta e credibilidade de } \\
\text { diversas padronizadoras e certificadoras, não só entre } \\
\text { as empresas, mas perante outros stakeholders; } \\
\text { "Penalização" para empresas com maior } \\
\text { comprometimento, devido à confusão causada pelo } \\
\text { grande número de apelos sustentáveis; } \\
\text { Incertezas em relação ao nível de compreensão e } \\
\text { valorização por parte dos consumidores. }\end{array}$ \\
\hline 6 & Maquiagem verde & $\begin{array}{l}\text { Sim } \\
\text { Sem necessidade } \\
\text { de alterar texto } \\
\text { final }\end{array}$ & $\begin{array}{l}\text { Apelos sustentáveis perderam credibilidade com o } \\
\text { passar do tempo devido a quantidade de apelos } \\
\text { inseridos no mercado sem a devida contrapartida por } \\
\text { parte da empresa. }\end{array}$ \\
\hline 7 & $\begin{array}{l}\text { Falta de ferramentas e } \\
\text { consequente dificuldade } \\
\text { para mensurar impactos }\end{array}$ & Não & $\begin{array}{l}\text { Incerteza em relação aos impactos efetivos da } \\
\text { certificação no meio ambiente e/ou na sociedade; } \\
\text { Falta de bancos de dados e informações; } \\
\text { Falta de garantias sobre informações disponíveis; } \\
\text { Dificuldade em saber quais são os melhores materiais } \\
\text { disponíveis. }\end{array}$ \\
\hline 8 & $\begin{array}{l}\text { Falta de comprovação } \\
\text { dos benefícios da } \\
\text { certificação }\end{array}$ & Não & $\begin{array}{l}\text { Indagação se investimentos necessários são } \\
\text { compensados. }\end{array}$ \\
\hline 9 & $\begin{array}{l}\text { Processo de definição de } \\
\text { critérios e/ou mensuração } \\
\text { das certificações }\end{array}$ & Não & $\begin{array}{l}\text { Critérios definidos com base em interesses próprios, } \\
\text { baseados em percepções ou questões políticas, não em } \\
\text { ciência; } \\
\text { Não há uma metodologia definitiva aceita pelos } \\
\text { diversos stakeholders envolvidos no processo; } \\
\text { Dificuldades em se comparar ciclos de vida de } \\
\text { produtos tão diferentes; } \\
\text { Padrões muito dominados pelos grupos de interesse } \\
\text { e/ou suscetíveis aos mesmos; } \\
\text { Falta de transparência por parte das certificadoras e/ou } \\
\text { padronizadoras. }\end{array}$ \\
\hline
\end{tabular}


(continuação)

\begin{tabular}{|c|c|c|c|}
\hline & Barreira & Citada no caso? & Descrição final \\
\hline 10 & $\begin{array}{l}\text { Aumento da } \\
\text { complexidade da cadeia } \\
\text { de custódia com aumento } \\
\text { da globalização }\end{array}$ & Não & $\begin{array}{l}\text { Dificuldade de se estabelecer padrões que sejam } \\
\text { relevantes globalmente, dado que cada região tem } \\
\text { prioridades ambientais diferentes; } \\
\text { Dificuldade de mensurar impactos com fornecimento } \\
\text { sendo realizados a partir de diversas regiões; } \\
\text { Descentralização de operações das empresas, o que } \\
\text { amplia carteira de fornecedores e abre espaço para } \\
\text { sub-contratações, o que dificulta a rastreabilidade; } \\
\text { Produtores de países em desenvolvimento podem } \\
\text { enfrentar dificuldades de entrada em países } \\
\text { desenvolvidos; } \\
\text { Regras estabelecidas em acordos internacionais de } \\
\text { comércio. }\end{array}$ \\
\hline 11 & Escala & $\begin{array}{l}\text { Sim } \\
\text { Sem necessidade } \\
\text { de alterar texto } \\
\text { final }\end{array}$ & $\begin{array}{l}\text { Tamanho e capacidade das padronizadoras e } \\
\text { certificadoras; } \\
\text { Muitos esquemas ainda são de nicho, não tendo escala } \\
\text { necessária para atender grandes empresas. }\end{array}$ \\
\hline 12 & $\begin{array}{l}\text { Design das embalagens }{ }^{48} \\
\text { Decisões de Marketing }\end{array}$ & $\begin{array}{l}\text { Sim } \\
\text { Proposta de } \\
\text { alteração de texto }\end{array}$ & $\begin{array}{l}\text { Falta de espaço na embalagem para comunicar } \\
\text { certificação; } \\
\text { Designers que não querem colocar a certificação em } \\
\text { suas peças criativas; } \\
\frac{\text { Competição entre atributos dos produtos a serem }}{\text { comunicados nos diversos meios de comunicação; }} \\
\underline{\text { Alinhamento das certificações apenas com marcas que }} \\
\underline{\text { busquem posicionamento social e/ou ambiental; }} \\
\underline{\text { Dificuldade de mapear segmentos que valorizem }} \\
\underline{\text { aspectos sociais e/ou ambientais; }} \\
\underline{\text { Dúvidas sobre quais diferenciais poderiam se }} \\
\underline{\text { comunicados (nos casos em que empresas não sejam }} \\
\underline{\text { as primeiras a utilizarem o insumo certificado); }} \\
\underline{\text { Algumas certificações tem logotipos que podem }} \\
\underline{\text { causar estranhamento e repulsa; }} \\
\underline{\text { Opção por desenvolver logotipos próprios/exclusivos }} \\
\text { para comunicar atributos sustentáveis e/ou não fazer } \\
\underline{\text { uso das logomarcas das certificações. }}\end{array}$ \\
\hline 13 & $\begin{array}{l}\text { Incerteza em relação ao } \\
\text { futuro }\end{array}$ & $\begin{array}{l}\text { Sim } \\
\text { Proposta de } \\
\text { alteração de texto }\end{array}$ & $\begin{array}{l}\text { Dúvidas sobre aumento ou não da demanda por } \\
\text { certificações; } \\
\text { Dúvidas sobre como papel das certificações vai se } \\
\text { desenvolver; } \\
\text { Tendência de fortalecimento na confiança às marcas } \\
\text { devido à políticas de transparência radical reduziria } \\
\text { necessidade de certificações. }\end{array}$ \\
\hline 14 & Inibe inovação & Não & $\begin{array}{l}\text { Para atender requisitos empresas acabam não } \\
\text { investindo em melhorias nos produtos certificados. }\end{array}$ \\
\hline
\end{tabular}

\footnotetext{
${ }^{48}$ Optou-se por renomear a barreira "Design de embalagens" para "Decisões de Marketing", dado que as questões mencionadas fazem parte das atividades de um gestor de Marketing de produtos.
} 
(continuação)

\begin{tabular}{|c|c|c|c|}
\hline & Barreira & Citada no caso? & Descrição final \\
\hline 15 & $\begin{array}{l}\text { Conexão entre marcas } \\
\text { (da empresa e da } \\
\text { padronizadora) }\end{array}$ & $\begin{array}{l}\text { Sim } \\
\text { Proposta de } \\
\text { alteração de texto }\end{array}$ & $\begin{array}{l}\text { Se houver algum problema com a padronizadora, a } \\
\text { marca da empresa também poderá ser afetada; } \\
\text { Opção por não divulgar outras marcas, não fazendo } \\
\underline{\text { uso do logotipo das certificações; }} \\
\text { Estranhamento causado por certas certificações. }\end{array}$ \\
\hline 16 & $\begin{array}{l}\text { Esforço de coordenação e } \\
\text { complexidade }\end{array}$ & $\begin{array}{l}\text { Sim } \\
\text { Proposta de } \\
\text { alteração de texto }\end{array}$ & $\begin{array}{l}\text { Demanda por muitas informações; } \\
\text { Necessidade de realização de auditorias e } \\
\text { treinamentos internos; } \\
\text { Complexidade das operações realizadas; } \\
\text { Necessidade de disponibilizar tempo dos } \\
\text { colaboradores para auxiliar na implantação; } \\
\text { Diversos documentos (oficiais ou não) com } \\
\text { orientações de como fazer uso de comunicações } \\
\text { sustentáveis; } \\
\text { Exigências em relação à aplicações das marcas; } \\
\text { Processo de adequação a padrões pode ser muito } \\
\text { longo, desestimulando colaboradores. }\end{array}$ \\
\hline 17 & $\begin{array}{l}\text { Estrutura organizacional } \\
\text { das empresas }\end{array}$ & $\begin{array}{l}\text { Sim } \\
\text { Proposta de } \\
\text { alteração de texto }\end{array}$ & $\begin{array}{l}\text { Estrutura não preparada para lidar com certificações } \\
\text { sustentáveis; } \\
\text { Necessidade de a alta gestão ser mais envolvida com o } \\
\text { tema; } \\
\text { Baixa escolaridade de colaboradores, dificuldades em } \\
\text { mexer nas ferramentas; } \\
\text { Falta de envolvimento da área de marketing na } \\
\text { demanda por certificações; } \\
\text { Falta de troca de informações sobre sustentabilidade } \\
\text { entre áreas internas/colaboradores. }\end{array}$ \\
\hline 18 & $\begin{array}{l}\text { Problemas de } \\
\text { fornecimento }\end{array}$ & $\begin{array}{l}\text { Sim } \\
\text { Proposta de } \\
\text { alteração de texto }\end{array}$ & $\begin{array}{l}\text { Não encontra fornecedores que tenham certificação; } \\
\text { No caso de matérias primas, limita flexibilidade de } \\
\text { fornecimento para poucos fornecedores certificados; } \\
\text { Não conseguem obter informações de toda a cadeia de } \\
\text { fornecimento; } \\
\text { Novos insumos certificados nem sempre conseguem } \\
\text { atender demandas técnicas dos processos produtivos } \\
\text { das empresas. }\end{array}$ \\
\hline 19 & $\begin{array}{l}\text { Falta de conhecimento, } \\
\text { compreensão e } \\
\text { valorização das } \\
\text { certificações }\end{array}$ & $\begin{array}{l}\text { Sim } \\
\text { Sem necessidade } \\
\text { de alterar texto } \\
\text { final }\end{array}$ & $\begin{array}{l}\text { Certificações não são consideradas como fator de } \\
\text { decisão de compra } \\
\text { A adoção de certificações não é valorizada pelos } \\
\text { stakeholders }\end{array}$ \\
\hline
\end{tabular}


(conclusão)

\begin{tabular}{|c|c|c|c|}
\hline & Barreira & Citada no caso? & Descrição final \\
\hline 20 & $\begin{array}{l}\text { Falta de maior } \\
\text { posicionamento do poder } \\
\text { público }\end{array}$ & $\begin{array}{l}\text { Sim } \\
\text { Proposta de } \\
\text { alteração de texto }\end{array}$ & $\begin{array}{l}\text { Governo poderia desenvolver e/ou indicar padrões que } \\
\text { fossem oficiais, a fim de orientar melhor empresas e } \\
\text { consumidores, e limitando a proliferação de } \\
\text { certificações; } \\
\text { Governo poderia inserir certificações como requisito } \\
\text { de compras públicas; } \\
\text { Governo poderia conceder incentivos fiscais a } \\
\underline{\text { empresas que buscam certificação e/ou já são }} \\
\text { certificadas. }\end{array}$ \\
\hline 21 & $\begin{array}{l}\text { Atuação dos } \\
\text { fornecedores de insumos } \\
\text { certificados, } \\
\text { certificadoras e } \\
\text { padronizadoras }\end{array}$ & Nova proposta & $\begin{array}{l}\text { Falta de maior divulgação e oferta das certificações; } \\
\text { Falta de propostas comerciais diferenciadas, de acordo } \\
\text { com a necessidade de cada cliente. }\end{array}$ \\
\hline 22 & Atuação de varejistas & Nova proposta & $\begin{array}{l}\text { Falta de valorização e incentivos por parte dos } \\
\text { varejistas. }\end{array}$ \\
\hline 23 & $\begin{array}{l}\text { Falta de política de } \\
\text { sustentabilidade da } \\
\text { empresa }\end{array}$ & Nova proposta & $\begin{array}{l}\text { A falta de uma política de sustentabilidade acaba por } \\
\text { não orientar/incentivar colaboradores na busca por } \\
\text { opções mais sustentáveis de produtos e processos; } \\
\text { Empresas brasileiras não costumam demandar } \\
\text { garantia de origem no fornecimento de insumos. }\end{array}$ \\
\hline 24 & Crise econômica & Nova proposta & $\begin{array}{l}\text { Crise econômica faz com que empresas tenham maior } \\
\text { orientação por resultados, reduzindo custos e inibindo } \\
\text { investimento em inovações. }\end{array}$ \\
\hline 25 & Aspectos culturais & Nova proposta & $\begin{array}{l}\text { Consumidor brasileiro não valoriza atitudes } \\
\text { socioambientais das empresas, seja por questões } \\
\text { culturais, de nível educacional ou de renda; } \\
\text { Empresas brasileiras não tem cultura voltada para } \\
\text { sustentabilidade; aspectos econômicos sobressaem no } \\
\text { momento das decisões. }\end{array}$ \\
\hline
\end{tabular}

Fonte: elaborado pela autora com base no levantamento bibliográfico e no resultado da pesquisa.

Posteriormente, buscou-se aplicar no mapeamento de stakeholders proposto na presente pesquisa (vide Figura 7, do tópico 2.2, p.56) todas as barreiras acima listadas, a fim de montar um primeiro modelo conceitual de atuação das barreiras às certificações sustentáveis, cujo objetivo é compreender como estes stakeholders envolvidos no processo influenciam e são influenciados por elas. Na Figura 13 pode-se verificar o resultado desta consolidação. Note-se que as setas circulares são relacionadas à barreiras internas às empresas, que foram listadas num quadro a parte, a direita, e as demais setas correspondem à quem está sendo influenciado pela barreira. Para facilitar a representação gráfica, optou-se por representar cada stakeholder pela sua letra inicial, sendo que no caso do certificador, foi necessário colocar também a 
segunda letra, a fim de diferenciá-lo de consumidor. Nos textos próximos às setas, a letra que aparece primeiro representa quem está sendo a origem da barreira, e a segunda representa quem está sendo impactado por ela. Se não há setas entre os grupos, significa que não foram mencionadas barreiras entre os mesmos. No canto inferior a direita listou-se as barreiras relacionadas ao contexto, como as questões referentes à globalização, as que foram classificadas como "Geral" e as relacionadas aos competidores. Em todos os casos, optou-se por colocar somente a barreira, e não os tópicos que constam em sua descrição, com exceção das barreiras "Atuação dos fornecedores de insumos certificados, certificadoras e padronizadoras" e "Problemas de fornecimento", a fim de se detalhar melhor as barreiras existentes dentre aqueles que seriam os principais envolvidos no processo de adoção das certificações pelas empresas de bens de consumo.

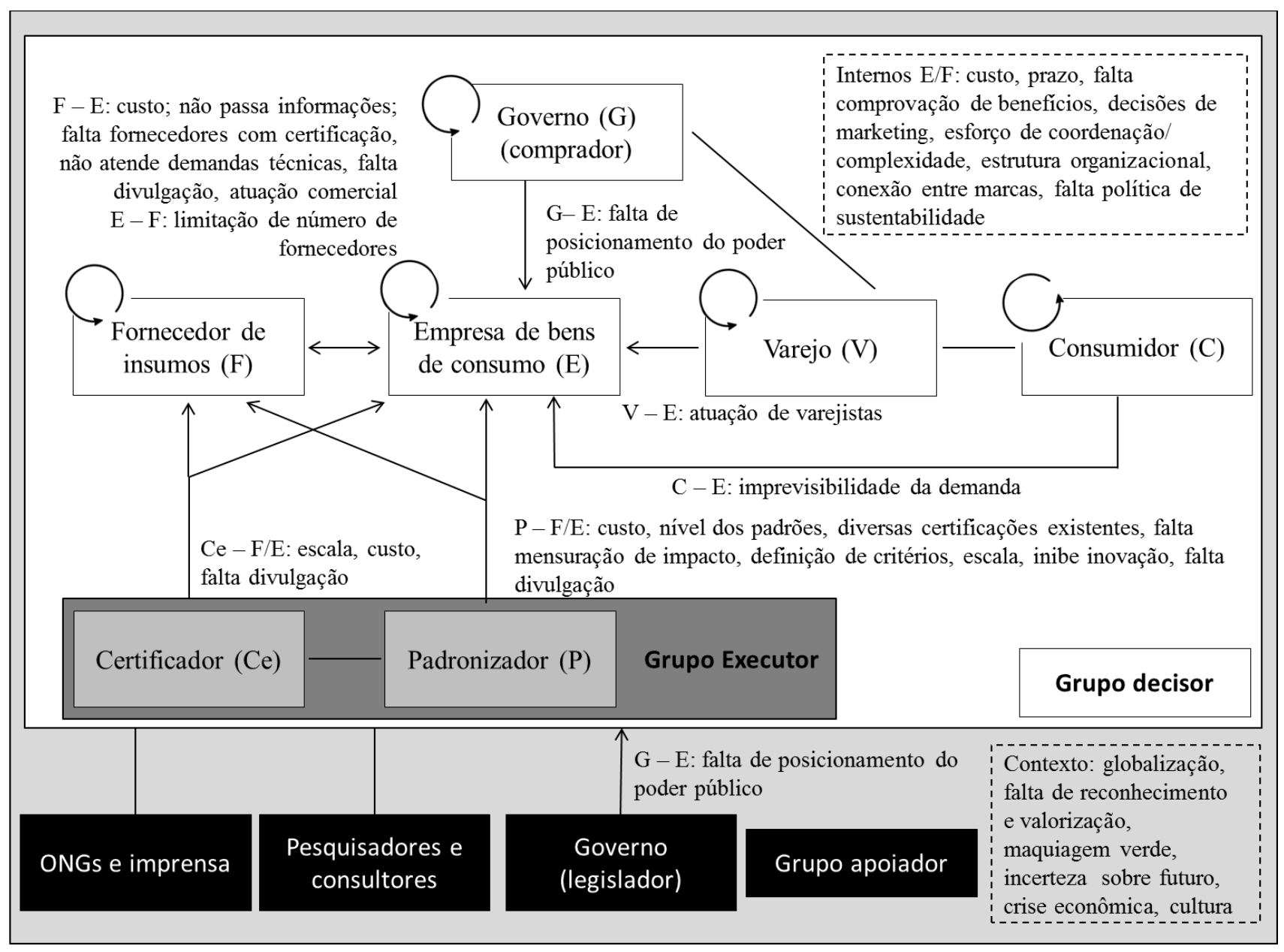

Figura 13 - Mapeamento de atuação das barreiras de acordo com cada stakeholder Fonte: elaborado pela autora com base nas referências bibliográficas. 
Por fim, foi feita uma primeira proposta de classificação das barreiras às certificações sustentáveis, com base no modelo de Walker e Jones (2012), e com as adaptações realizadas no desenrolar do presente trabalho. As novas categorias e subcategorias listadas durante todo o trabalho foram adicionadas às que já existiam no trabalho dos referidos autores, e o resultado pode ser visualizado na Tabela 42. Novamente as alterações foram sublinhadas para facilitar a sua identificação.

Tabela 42 - Proposta de classificação das barreiras às certificações sustentáveis

(continua)

\begin{tabular}{|c|c|c|c|}
\hline \multicolumn{2}{|r|}{ Barreiras Externas } & \multicolumn{2}{|r|}{ Barreiras Internas } \\
\hline Categoria & Subcategoria & Categoria & Subcategoria \\
\hline Governo & $\begin{array}{l}\text { Regulamentação; } \\
\text { Falta de incentivos. }\end{array}$ & Pessoas & $\begin{array}{l}\text { Falta de comprometimento dos } \\
\text { gestores. }\end{array}$ \\
\hline Competidores & $\begin{array}{l}\text { Pressão competitiva; } \\
\text { Maquiagem verde. }\end{array}$ & $\begin{array}{l}\text { Questões } \\
\text { estratégicas }\end{array}$ & $\begin{array}{l}\text { Limitação de recursos (custo e outros); } \\
\text { Mensuração de performance (métodos } \\
\text { contábeis tradicionais); } \\
\text { Tamanho das empresas (empresas } \\
\text { menores); } \\
\text { Falta de política de sustentabilidade; } \\
\text { Baixo envolvimento da área de } \\
\text { marketing na demanda por } \\
\text { certificações. }\end{array}$ \\
\hline Consumidores & $\begin{array}{l}\text { Demanda por preços mais baixos; } \\
\text { Compreensão sobre desejos e } \\
\text { comportamento; } \\
\text { Lacuna entre discurso e prática; } \\
\text { Baixo nível de escolaridade e de } \\
\text { renda (preço como fator de } \\
\text { decisão de compra). }\end{array}$ & $\begin{array}{l}\text { Questões } \\
\text { funcionais }\end{array}$ & $\begin{array}{l}\text { Função da área de compras (falta de } \\
\text { treinamento; falta de compreensão } \\
\text { sobre como incorporar as questões nas } \\
\text { compras; outras prioridades; falta de } \\
\text { estruturas e processos corporativos; } \\
\text { processo de GCSS ainda pouco } \\
\text { robusto); } \\
\text { Prazos para obter certificação; } \\
\text { Marketing (definições de produtos e } \\
\text { comunicação); } \\
\text { Esforço de coordenação e } \\
\text { complexidade; } \\
\text { Estrutura organizacional. }\end{array}$ \\
\hline Fornecedores & $\begin{array}{l}\text { Baixo envolvimento; } \\
\text { Muita pressão em um único } \\
\text { fornecedor por parte dos } \\
\text { consumidores; } \\
\text { Volumes muito altos significam } \\
\text { que a demanda pode ultrapassar } \\
\text { oferta; } \\
\text { Falta de fornecedores certificados; } \\
\text { Concentração de fornecimento; } \\
\text { Portfolio reduzido de insumos } \\
\text { certificados; } \\
\text { Falta de pro atividade na oferta de } \\
\text { insumos certificados; } \\
\text { Custo mais alto de insumos } \\
\text { certificados. }\end{array}$ & $\begin{array}{l}\text { Risco de } \\
\text { reputação }\end{array}$ & $\begin{array}{l}\text { Reputação de marca forte significa } \\
\text { gestão a mais de cadeia de suprimentos } \\
\text { sem necessariamente criar mais } \\
\text { demanda por seus produtos; } \\
\text { Conexão entre marcas (co-branding). }\end{array}$ \\
\hline
\end{tabular}


(conclusão)

\begin{tabular}{|c|c|c|c|}
\hline \multicolumn{2}{|r|}{ Barreiras Externas } & \multicolumn{2}{|r|}{ Barreiras Internas } \\
\hline Categoria & Subcategoria & Categoria & Subcategoria \\
\hline Mídia & $\begin{array}{l}\text { Maquiagem verde; } \\
\text { Volume de informações sobre } \\
\text { responsabilidade social } \\
\text { corporativa; }\end{array}$ & $\begin{array}{l}\text { Gestão de } \\
\text { performance }\end{array}$ & $\begin{array}{l}\text { Objetivos contrários de performance; } \\
\text { Auditorias muito extensas. }\end{array}$ \\
\hline Setorial & $\begin{array}{l}\text { Indústrias menos regulamentadas; } \\
\text { Códigos de conduta padronizados } \\
\text { limitam inovação; }\end{array}$ & $\begin{array}{l}\text { Tamanho da } \\
\text { organização }\end{array}$ & Operações em larga escala. \\
\hline ONGs & Exigências diversas. & $\begin{array}{l}\text { Integração } \\
\text { interna }\end{array}$ & Comunicação. \\
\hline Global & $\begin{array}{l}\text { Aspectos globais (barreiras de } \\
\text { idioma e culturais; certificações } \\
\text { diferentes em diferentes países; } \\
\text { certificações internacionais como } \\
\text { uma barreira à competitividade); } \\
\text { Necessidade de se definir se } \\
\text { fornecimento deve ser local ou } \\
\text { global; } \\
\text { Diferenças entre prioridades } \\
\text { socioambientais de cada região; } \\
\text { Descentralização da produção } \\
\text { dificulta rastreabilidade. }\end{array}$ & & \\
\hline Geral & $\begin{array}{l}\text { Incerteza em relação ao futuro do } \\
\text { mercado de certificações; } \\
\text { Falta de conhecimento, } \\
\text { compreensão e valorização das } \\
\text { cerificações; } \\
\text { Falta de demanda de mercado; } \\
\text { Crise econômica; } \\
\text { Aspectos culturais; } \\
\text { Tendência de transparência } \\
\text { radical. }\end{array}$ & & \\
\hline Padronizador & $\begin{array}{l}\text { Critérios da padronização (muito } \\
\text { rígidos, muito frouxos, revisões } \\
\text { constantes); } \\
\text { Número de esquemas existentes; } \\
\text { Falta de ferramentas para } \\
\text { mensurar impactos; } \\
\text { Transparência na definição de } \\
\text { critérios; } \\
\text { Envolvimento de stakeholders no } \\
\text { processo; } \\
\text { Escala e abrangência; } \\
\text { Não contempla critérios } \\
\text { relacionados à inovação; } \\
\text { Falta de divulgação; } \\
\text { Imagem de marca. }\end{array}$ & & \\
\hline Certificador & $\begin{array}{l}\text { Escala e abrangência; } \\
\text { Custo da auditoria. }\end{array}$ & & \\
\hline Varejo & $\begin{array}{l}\text { Falta de valorização e incentivos } \\
\text { por parte de varejistas. }\end{array}$ & & \\
\hline
\end{tabular}

Fonte: elaborado pela autora a partir de Walker e Jones (2012), das referências bibliográficas e dos dados empíricos coletados para o presente trabalho. 
Note-se que nem todas as categorias propostas por Walker e Jones (2012) foram usadas na classificação das barreiras levantadas na presente pesquisa, como mídia, setorial, ONGs e global (externas), e tamanho da organização e gestão de performance (internas). Das categorias que foram adicionadas ao modelo dos autores (geral, padronizador, certificador e varejo), a do certificador e do varejista foram as que tiveram menos subcategorias mencionadas tanto na revisão bibliográfica quanto na pesquisa empírica. 


\section{CONSIDERAÇÕES FINAIS}

O presente estudo teve como objetivo sistematizar as barreiras que dificultam a utilização das certificações sustentáveis por parte de empresas de bens de consumo, sob a ótica dos principais stakeholders envolvidos no processo. Na referência bibliográfica foram levantadas diversas barreiras às certificações, sem ser possível encontrar uma iniciativa de consolidação e sistematização das mesmas. Com isso, foi feita uma proposta de modelo conceitual que pudesse relacionar os principais stakeholders envolvidos com as certificações de empresas de bens de consumo com as barreiras a eles relacionadas, e uma busca em outros campos de estudo que pudessem oferecer um suporte neste desenvolvimento. Este objetivo foi atingido ao tomar-se conhecimento do campo de estudos relacionado à Gestão da Cadeia de Suprimentos Sustentável (GCSS), o qual possui um amplo arcabouço teórico desenvolvido, contando também com estudos relacionados às barreiras à mesma. Dado que a compra de insumos certificados por parte das empresas de bens de consumo está relacionada com a gestão de fornecimento, concluiu-se que esta seria uma boa referência ao presente estudo.

Após analisar as diversas propostas de classificação de barreiras à GCSS existentes na literatura, optou-se pela de Walker e Jones (2012), por se tratar de um estudo que não tinha foco em nenhum segmento específico de indústria, e também por considerar as barreiras conforme o stakeholder que a gerou. Foram, então, analisados dois casos de certificações relevantes no Brasil, o FSC e o "I'm Green", tendo sido realizadas entrevistas com representantes de fornecedores certificados, empresas de bens de consumo que aderiram ou não as certificações, além de uma das maiores certificadoras FSC do Brasil, a Imaflora, e os próprios FSC e Braskem, responsáveis pelas certificações.

O resultado desta análise foi: i) a atualização da listagem de barreiras previamente levantada, deixando-a mais completa; ii) a primeira proposta de classificação destas barreiras, com base no trabalho de Walker e Jones (2012), que foi atualizado de acordo com questões específicas das certificações; e iii) o primeiro mapeamento da atuação das barreiras de acordo com o stakeholder envolvido no processo. Nota-se que os obstáculos enfrentados pelas empresas de bens de consumo são principalmente referentes à sua relação com seus fornecedores de insumo e os padronizadores, além de diversas questões internas à organização. 
Uma nova proposta de classificação feita pela autora, que considera as barreiras de acordo com a fase de implementação das mesmas. Observa-se que as barreiras comuns às duas certificações estão concentradas na fase inicial de adoção das mesmas, e são oriundas, em sua maioria dos stakeholders externos. Já as barreiras específicas de cada certificação tem algumas particularidades: no caso do FSC elas estão concentradas na fase de implementação, e envolve uma gama maior de stakeholders, sendo que no caso "I'm Green" há uma dispersão entre a fase anterior de implementação, e a fase de implementação, propriamente, sendo que elas são muito focadas no fornecedor. Sugere-se que isso se deva ao fato de o "I'm Green" ser produzido por um único fornecedor, que deve buscar a certificação, sendo que os demais atores da cadeia apenas compram o insumo certificado, e ainda pagam um preço mais alto por isso, que foi considerado um dos principais obstáculos para o mesmo. No caso do FSC, a certificação envolve uma entidade padronizadora e uma certificadora, além de adaptações internas de processos das empresas, o que pode gerar maior complexidade.

Além disso, também foi possível levantar principais motivações para se obter as certificações, as áreas envolvidas na implementação, considerações sobre prazos e investimentos, e impactos causados, tanto positivos quanto negativos. Outras contribuições estiveram relacionadas a: i) uma nova proposta de classificação das certificações, que considera o que está sendo avaliado pela mesma (vide tópico 2.1.4); ii) uma nova proposta de organização dos termos utilizados no contexto da rotulagem sustentável (vide tópico 2.1.4); iii) o levantamento atualizado dos selos e certificações presentes no Brasil (vide tópico 2.1.5); e iv) um novo mapeamento de stakeholders, com a divisão dos mesmos de acordo com sua atuação no processo de adoção das certificações (vide tópico 2.2). Para facilitar a avaliação do cumprimento dos objetivos específicos do presente estudo, buscou-se resgatá-los para que fossem feitos comentários a respeito de cada um, o que pode ser verificado na Tabela 43:

Tabela 43 - Resultados alcançados

(continua)

\begin{tabular}{l|l}
\hline Objetivos específicos & Comentários \\
\hline $\begin{array}{l}\text { Mapear o processo de decisão pela utilização } \\
\text { das certificações nas empresas, para que seja } \\
\text { possível avaliar como as barreiras atuam }\end{array}$ & $\begin{array}{l}\text { Foi mapeado o processo de adoção das certificações, } \\
\text { resultando no mapeamento de atuação das barreiras de } \\
\text { acordo com cada stakeholder envolvido no processo }\end{array}$ \\
\hline $\begin{array}{l}\text { Levantar outras questões relacionadas à } \\
\text { adoção das certificações, como motivações, } \\
\text { prazos envolvidos, investimento necessários e } \\
\text { impactos causados }\end{array}$ & $\begin{array}{l}\text { Foi possível levantar as principais motivações para se } \\
\text { obter as certificações, diversas considerações sobre prazos } \\
\text { e investimentos e impactos causados (tanto positivos } \\
\text { quanto negativos) }\end{array}$ \\
\hline
\end{tabular}


(conclusão)

\begin{tabular}{l|l}
\hline Objetivos específicos & Comentários \\
\hline $\begin{array}{l}\text { Levantar quais são as áreas das empresas mais } \\
\text { relacionadas à questão da certificação sustentável, } \\
\text { a fim de compreender papéis e responsabilidades } \\
\text { de cada uma no processo de certificação }\end{array}$ & $\begin{array}{l}\text { As áreas de Produção, Projetos, Suprimentos e } \\
\text { Marketing e/ou comercial foram as citadas por todos os } \\
\text { entrevistados, em ambos os casos }\end{array}$ \\
\hline $\begin{array}{l}\text { Avaliar se há semelhanças em relação às barreiras } \\
\text { encontradas para diferentes certificações }\end{array}$ & $\begin{array}{l}\text { Há diferenças relevantes em relação ao momento em } \\
\text { que as barreiras exercem seu impacto, e também a } \\
\text { origem das mesmas }\end{array}$ \\
\hline
\end{tabular}

Fonte: elaborado pela autora.

Acredita-se que as certificações podem dar aos executivos de negócios uma referência coletiva de ação, sendo que quanto mais empresas aderirem, um movimento será criado (SustainAbility, 2011). Esta questão também foi colocada por Fabíola Zerbini, para quem uma empresa, ao ver seu concorrente obtendo uma certificação, se interessaria mais pelo assunto, a fim de não ficar em desvantagem. Porém ainda restam muitas dúvidas sobre a efetividade das certificações, por falta de métricas e ferramentas que possam auferi-las, a fim de que se possa obter comprovações sobre os impactos e benefícios socioambientais e econômicos gerados, como o aumento das vendas dos produtos certificados. Isso faz com que o futuro ainda seja bastante incerto em relação ao tema.

Esta dissertação abriu espaço para uma maior compreensão sobre como a questão da rotulagem sustentável vem sendo considerada no ambiente corporativo. Para os acadêmicos, pode ser considerado um passo para incentivar futuras iniciativas que aprofundem o conhecimento das barreiras: seja por parte de cada stakeholder em específico, de um maior detalhamento de suas relações, da mensuração do potencial de impacto de cada uma, ou ainda da avaliação das conexões existentes entre elas (relações de causa e efeito). Além destes estudos mais aprofundados sobre barreiras, as discussões levantadas na presente pesquisa também possibilitam aumentar a abrangência do debate acerca das certificações sustentáveis no contexto empresarial, como aprofundar o conhecimento do papel que elas exercem nas relações $\mathrm{B} 2 \mathrm{~B}$ e nas relações $\mathrm{B} 2 \mathrm{C}$, e como estas duas relações poderiam ser integradas para gerar mais valor à empresa. Esta proposição é feita com base em autores como Chan et al. (2012 e Gupta, Rudd, e Lee (2014), que apresentam edições especiais de periódicos acadêmicos internacionais relacionados à integração das áreas de marketing e operações com objetivo de criar valor em questões relacionadas à sustentabilidade. Neste cenário, as certificações sustentáveis são uma das ferramentas possíveis que consolidam estas relações, 
conforme pode ser visto na Figura 14: os estudos relacionados às formas de se conquistar diferenciação de mercado com foco em varejistas e consumidores finais estão mais alinhados com questões de marketing; os estudos relacionados à gestão da cadeia de suprimentos com foco em implementar políticas de sustentabilidade estão mais alinhados com questões de operações; a integração das duas áreas de estudo podem ser possível fonte de criação de valor sustentável para toda a cadeia, no longo prazo.

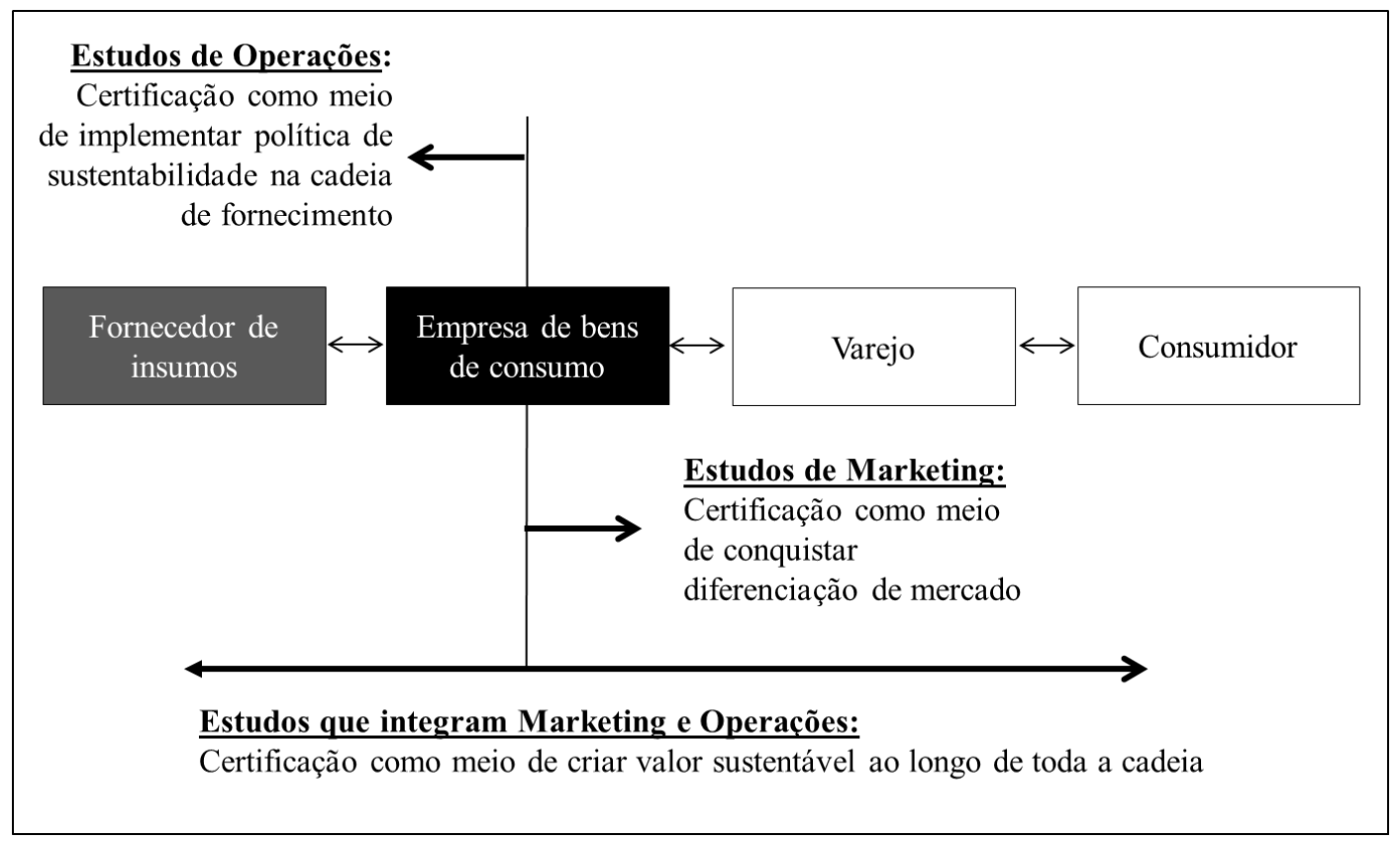

Figura 14 - Os estudos sobre certificações em diferentes contextos Fonte: elaborado pela autora.

Já para as empresas, a gestão do relacionamento com parceiros externos e um esforço coordenado entre as áreas internas relacionadas com desenvolvimento de produtos e/ou serviços podem ser considerados determinantes para o sucesso da adoção das certificações sustentáveis, pois há indícios de que as empresas de bens de consumo são grandes alavancadoras das certificações, ao demanda-las de seus parceiros comerciais e apoiálos em sua adoção, e ao comunica-las aos consumidores finais e incentivar sua preferência. Por fim, também foi identificada a importância de se possuir uma política de sustentabilidade formal, se esse for um valor importante para a organização, a fim de orientar melhor os colaboradores sobre os seus objetivos socioambientais. Para as padronizadoras, ressalta-se a necessidade de maior envolvimento dos stakeholders em todo o esquema, além de a necessidade urgente de maior mensuração e divulgação de seus impactos. 


\subsection{Limitações e sugestão de estudos futuros}

O presente estudo, de caráter exploratório, teve por objetivo ampliar o conhecimento acerca das certificações sustentáveis, por meio do levantamento livre de barreiras por parte dos respondentes, que atualizaram a listagem previamente realizada pela autora com base na revisão bibliográfica, e com posterior proposta de caminhos para a sistematização destas barreiras. Faz-se claro que os resultados não são passíveis de generalização, sendo que novos estudos poderão detalhar melhor a opinião dos stakeholders envolvidos em relação a cada barreira em específico, além de um levantamento mais aprofundado sobre a proposta de solução para cada uma delas.

O estudo foi relacionado a dois casos de certificações aplicadas a embalagens, sendo que há diversos outros tipos presentes no Brasil e no mundo. Sugere-se a possibilidade de levantamento de barreiras referentes a outras certificações, aplicadas a partes do processo e/ou do produto e/ou das empresas como um todo, a fim de levantar semelhanças e diferenças e, evoluir na forma de classificação das mesmas. A questão da diversidade no perfil das empresas poderia ter sido melhor explorada, abrindo espaço para um maior detalhamento em relação às diferenças existentes entre perfil de empresas - grandes versus pequenas, de capital nacional ou estrangeiro, que adotam ou não adotam as certificações.

Além disso, foram levantadas diversas propostas de sistematização das barreiras a GCSS, sendo que há possibilidade de que outras sejam mais aderentes ao caso das certificações. A relação das certificações de terceira parte com o tema da cadeia de suprimentos sustentável também ainda foi pouco explorada, dado que nos estudos avaliados a referência a certificações eram sempre relacionadas ao sistema ISO relacionado a gestão ambiental e social.

Dado que este campo de conhecimento ainda é incipiente, abre-se espaço para diversos outros estudos, como a mensuração da relevância de cada uma, e a relações entre as categorias de barreiras. Como exemplos, pode-se citar como a falta de divulgação impacta a falta de demanda; se o baixo envolvimento da área de marketing na demanda por certificações está relacionado com a falta de mensuração de resultados e/ou falta de comprovação de benefícios por parte das certificações; e se o problema de escala impacta no aumento da adesão às certificações, dentre diversas outras relações que podem sugeridas e testadas. 


\section{REFERÊNCIAS BIBLIOGRÁFICAS}

Anderson, W. T., \& Cunningham, W. H. (1972). The Socially Conscious Consumer. Journal of Marketing, 36(3), 23-31.

Andreoni, M. (2013). Selos verdes contribuem para práticas sustentáveis. Retrieved April 21, 2016, from http://oglobo.globo.com/sociedade/ciencia/revista-amanha/selos-verdescontribuem-para-praticas-sustentaveis-9623393

Antil, J. H. (1984). Socially responsible consumers: profile and implications for public policy. Journal of Macromarketing, 5(2), 18. http://doi.org/10.1177/027614678400500203

Associação Brasileira de Embalagens [ABRE]. (2012). Diretrizes de rotulagem ambiental para embalagens - autodeclarações ambientais (rotulagem do tipo II). Retrieved October 10, 2016, from http://www.abre.org.br/wpcontent/uploads/2012/07/cartilha_rotulagem.pdf

Bader, L., \& Hotchkiss, G. B. (1940). Attitudes of teachers of marketing toward consumer grade labeling. Journal of Marketing, 6(April), 274-279.

Balasubramanian, S. (2012). A hierarchical framework of barriers to green supply chain management in the construction sector. Journal of Sustainable Development, 5(10), 1528. http://doi.org/10.5539/jsd.v5n10p15

Bandeira-de-Mello, R. (2010). Softwares em pesquisa qualitativa. In Pesquisa Qualitativa em Organizações: Paradigmas, Estratégias e Métodos (pp. 429-460). São Paulo: Saraiva.

Barbieri, J. C., \& Cajazeira, J. E. R. (2009). Avaliação do ciclo de vida do produto como instrumento de gestão da cadeia de suprimento - o caso do papel reciclado. In Simpósio de Administração da Produção, Logística e Operações Internacionais (p. 16).

Barbosa, L., Portilho, F., Wilkinson, J., \& Dubeux, V. (2014). Trust, participation and political consumerism among Brazilian youth. Journal of Cleaner Production, 63, 93101. http://doi.org/10.1016/j.jclepro.2013.08.044

Barbosa, L., \& Veloso, L. (2014). Consumption, domestic life and sustainability in Brazil. Journal of Cleaner Production, 63, 166-172. http://doi.org/10.1016/j.jclepro.2013.09.020

Bardin, L. (1977). Análise de conteúdo. Lisboa: Edições 70.

Bartley, T. (2003). Certifying forests and factories: states, social movements, and the rise of private regulation in the apparel and forest products fields. Politics \& Society, 31(3), 433-464. http://doi.org/10.1177/0032329203254863

Berg, B. L. (2004). Qualitative research methods for the social sciences (5th ed.). Boston: Pearson.

Berkowitz, L., \& Lutterman, K. G. (1968). The traditional socially responsible personality. The Public Opinion Quarterly, 32(2), 169-185.

Bernick, L. (2016). The $\$ 100$ billion business case for safer chemistry. Retrieved August 10, 2016, from https://www.greenbiz.com/article/100-billion-business-case-safer-chemistry

Bhaskaran, S., Polonsky, M., Cary, J., \& Fernandez, S. (2006). Environmentally sustainable food production and marketing. British Food Journal, 108(8), 677-690. http://doi.org/10.1108/00070700610682355

Bombril. (2015). Relatório de Sustentabilidade 2015.

Bonini, S., \& Jeremy M. Oppenheim. (2010). The Next Environmental Issue for Business. McKinsey Quarterly, 1-8. Retrieved from https://www.mckinseyquarterly.com/The_next_environmental_issue_for_business_McK insey_Global_Survey_results_2651

Borin, N., Cerf, D. C., \& Krishnan, R. (2011). Consumer effects of environmental impact in product labeling. Journal of Consumer Marketing, 28(1), 76-86.

http://doi.org/10.1108/07363761111101976 
Braskem. (2007). Braskem tem o primeiro Polietileno verde certificado do Mundo. Retrieved January 2, 2017, from https://www.braskem.com.br/detalhe-noticia/Braskem-tem-oprimeiro-Polietileno-verde-certificado-do-Mundo

Braskem. (2008a). Braskem anuncia investimentos de mais de $\mathrm{R}$ \$ 1,0 bilhão no Rio Grande do Sul. Retrieved January 2, 2017, from https://www.braskem.com.br/detalhenoticia/Braskem-anuncia-investimentos-de-mais-de-R-1,0-bilhao-no-Rio-Grande-do-Sul

Braskem. (2008b). Braskem conclui aprovação do projeto de polietileno verde. Retrieved January 4, 2017, from https://www.braskem.com.br/detalhe-noticia/Braskem-concluiaprovacao-do-projeto-de-polietileno-verde

Braskem. (2008c). Braskem e Toyota Tsusho iniciam operações conjuntas de comercialização do polietileno verde na Ásia. Retrieved January 2, 2017, from https://www.braskem.com.br/detalhe-noticia/Braskem-e-Toyota-Tsusho-iniciamoperacoes-conjuntas-de-comercializacao-do-polietileno-verde-na-Asia

Braskem. (2009). SUNDOWN® - Proteção solar sustentável. Retrieved January 2, 2017, from https://www.braskem.com.br/detalhe-noticia/SUNDOWN-Protecao-solar-sustentavel

Braskem. (2010). Braskem lança selo para produtos de fontes renováveis. Retrieved January 2, 2017, from https://www.braskem.com.br/detalhe-noticia/Braskem-lanca-selo-paraprodutos-de-fontes-renovaveis

Braskem. (2012). Relatório Anual 2012.

Braskem. (2013). L’Occitane en Provence lança linha com plástico verde da Braskem.

Retrieved January 4, 2017, from http://www.braskem.com.br/detalhe-noticia/L-Occitaneen-Provence-lanca-linha-com-plastico-verde-da-Braskem

Braskem. (2014). Relatório Anual 2014.

Braskem. (2015). Relatório Anual 2015.

Braskem. (2016). Novas embalagens de Cuide-se Bem utilizam material 100\% renovável. Retrieved January 6, 2017, from https://www.braskem.com.br/detalhe-noticia/novasembalagens-de-cuide-se-bem-utilizam-material-100-renovavel

Braskem. (2017a). Braskem - certificados PE Verde. Retrieved January 1, 2017, from http://www.braskem.com/site.aspx/Certificados-Peverde

Braskem. (2017b). Braskem - perguntas e respostas PE verde. Retrieved January 1, 2017, from http://www.braskem.com/site.aspx/FAQ_PeVerde

Bray, J., Johns, N., \& Kilburn, D. (2011). An exploratory study into the factors impeding ethical consumption. Journal of Business Ethics, 98, 597-608. http://doi.org/10.1007/s10551-010-0640-9

Brécard, D. (2014). Consumer confusion over the profusion of eco-labels: Lessons from a double differentiation model. Resource and Energy Economics, 37, 64-84. http://doi.org/10.1016/j.reseneeco.2013.10.002

Bruce, C., \& Laroiya, A. (2007). The production of eco-labels. Environmental and Resource Economics, 36(3), 275-293. http://doi.org/10.1007/s10640-006-9028-9

Centro de Estudos em Sustentabilidade - GVces. (2016). O Programa Brasileiro GHG Protocol. Retrieved April 1, 2016, from http://cms-ghg-staging.herokuapp.com/oprograma-brasileiro-ghg-protocol?locale $=$ pt-br

Chan, H. K., He, H., \& Wang, W. Y. C. (2012). Green marketing and its impact on supply chain management in industrial markets. Industrial Marketing Management, 41(4), 557562. http://doi.org/10.1016/j.indmarman.2012.04.002

Coelho, S. L. (2015). Fair trade consumers in Portugal: values and lifestyles. International Journal of Consumer Studies, 39(5), 437-444. http://doi.org/10.1111/ijcs.12232

Cohen, M. A., \& Vandenbergh, M. P. (2012). The potential role of carbon labeling in a green economy. Energy Economics, 34(SUPPL.1), S53-S63.

http://doi.org/10.1016/j.eneco.2012.08.032 
Coles, J. V, \& Erdman, H. E. (1945). Some aspects of the arguments against grade labeling. Journal of Marketing, 9(3), 256-261.

Coltro, A., \& Kruglianskas, I. (2006). Estímulos de mercado às ações institucionais socioambientais: os Selos de Qualidade Assegurada são decodificados? Revista de Gestão USP, 13, 61-77.

Compact, U. G., \& Accenture CEO Study. (2015). UN Global Compact-Accenture CEO Study - Special Edition: A Call to Climate Action.

Compromisso Empresarial para Reciclagem - CEMPRE. (n.d.). A rotulagem ambiental aplicada às embalagens.

Consumers International. (1999). Green claims - environmental claims on products and packaging in the shops: an international study.

Cornelissen, G., Dewitte, S., Warlop, L., \& Yzerbyt, V. (2007). Whatever people say I am, that's what I am: Social labeling as a social marketing tool. International Journal of Research in Marketing, 24(4), 278-288. http://doi.org/10.1016/j.ijresmar.2007.05.001

Correio do Povo. (2011). Mulheres fazem protesto - Integrantes da Via Campesina fizeram manifestação de preparação ao Dia Internacional da Mulher. Retrieved January 6, 2017, from http://www.correiodopovo.com.br/Impresso/?Ano=116\&Numero $=153 \&$ Caderno $=0 \&$ Not icia $=263305$

Counsell, S., \& Loraas, K. T. (2002). Trading in credibility - the myth and reality of the Forest Stewardship Council. Main.

Creswell, J. W. (2013). Qualitative inquiry and research design: choosing among five approaches (3rd ed.). Thousand Oaks: Sage Publications.

D'Souza, C. (2000). Bridging the communication gap: dolphin-safe "ecolabels." Corporate Communications: An International Journal, 5, 185-190. http://doi.org/10.1108/13563280010379129

D’Souza, C. (2004). Ecolabel programmes: a stakeholder (consumer) perspective. Corporate Communications: An International Journal, 9(3), 179-188. http://doi.org/10.1108/13563280410551105

D’Souza, C., Taghian, M., \& Lamb, P. (2006). An empirical study on the influence of environmental labels on consumers. Corporate Communications: An International Journal, 11(2), 162-173. http://doi.org/10.1108/13563280610661697

De Pelsmacker, P., \& Janssens, W. (2007). A model for fair trade buying behaviour: The role of perceived quantity and quality of information and of product-specific attitudes. Journal of Business Ethics, 75(4), 361-380. http://doi.org/10.1007/s10551-006-9259-2

Deus, N. S., Felizola, M. P. M., \& Silva, C. E. (2010). O consumidor socioambiental e seu comportamento frente aos selos de produtos responsáveis. Revista Brasileira de Administração Científica, 1(1), 32-54. http://doi.org/10.6008/ESS2179

Drumwright, M. E. (1994). Socially Responsible Organizational Buying : Environmental Concern as a Noneconomic Buying Criterion. Journal of Marketing, 58(3), 1-19.

Dyer, W. G. J., \& Wilkins, A. L. (1991). Better stories, not better constructs, to generate better theory: a rejoinder to Eisenhardt. Academy of Management Review, 16(3), 613619. http://doi.org/10.5465/AMR.1991.4279492

Ecolabel Index. (2016). Ecolabel Index. Retrieved April 18, 2016, from http://www.ecolabelindex.com/

Eisenhardt, K. M. (1989). Building theories from case study research. The Academy of Management Review, 14(4), 532-550. http://doi.org/10.2307/258557

Eisenhardt, K. M. (1991). Better stories and better constructs: the case for rigor and comparative logic. The Academy of Management Review, 16(3), 620-627. http://doi.org/10.5465/AMR.1991.4279496 
Eisenhardt, K. M., \& Graebner, M. E. (2007). Theory building from cases: opportunities and challenges. Academy of Management Journal, 50(1), 25-32. http://doi.org/10.5465/AMJ.2007.24160888

European Commission. (2014). CONSUMER MARKET STUDY ON ENVIRONMENTAL CLAIMS FOR NON-FOOD PRODUCTS.

Federal Trade Comission [FTC]. (2012). Environmental Claims Summary of the Green Guides.

Forest Stewardship Council. (2012). FSC - Linha do tempo. Retrieved from https://br.fsc.org/pt-br/fsc-brasil/histrico

Forest Stewardship Council. (2015). Plano estratégico FSC brasil 2015 / 2020.

Forest Stewardship Council. (2016a). FSC website. Retrieved from https://ic.fsc.org/en Forest Stewardship Council. (2016b). Site do FSC. Retrieved from https://br.fsc.org/pt-br Forest Stewardship Council Brasil. (2017). A Associação ao FSC está aberta a uma ampla gama de organizações e indivíduos que representam interesses sociais, econômicos e ambientais. Retrieved January 2, 2017, from https://br.fsc.org/pt-br/fscbrasil/governana/cmaras-de-adeso

Gadema, Z., \& Oglethorpe, D. (2011). The use and usefulness of carbon labelling food: A policy perspective from a survey of UK supermarket shoppers. Food Policy, 36(6), 815822. http://doi.org/10.1016/j.foodpol.2011.08.001

Gallastegui, I. G. (2002). The use of eco-labels: a review of the literature. European Environment, 12(6), 316-331. http://doi.org/10.1002/eet.304

Gertz, R. (2005). Eco-labelling - a Case for Deregulation? Law, Probability and Risk, 4(3), 127-141. http://doi.org/10.1093/lpr/mgi010

Gibbert, M., \& Ruigrok, W. (2010). The what" and how" of case study rigor: three strategies based on published work. Organizational Research Methods, 13(4), 710-737. http://doi.org/10.1177/1094428109351319

Gies, E. (2014). Greenpeace and tissue giant Kimberly-Clark: from enemies to allies. The Guardian Sustainable Business.

Global Ecolabelling Network - GEN. (2004). Global Ecolabelling Network Information Paper: Introduction to Ecolabelling.

Global Footprint Network. (2016). Footprint Basics. Retrieved March 31, 2016, from http://www.footprintnetwork.org/en/index.php/GFN/page/footprint_basics_overview/

Golden, J. S. (2010). An overview of ecolabels and sustainability certifications in the global marketplace. Corporate Sustainability Initiative at Duke University and the Sustainability Consortium - Interim Report Document (Vol. \#2010-10-1).

Gomes, N. S., \& Júnior, E. F. C. (2016). O conhecimento e o ponto de vista de consumidores a respeito da rotulagem ambiental de produtos. Sustentabilidade Em Debate, 7(3), 7990. http://doi.org/10.18472/SustDeb.v7n3.2016.19273

Greenhouse Gas Protocol. (2016). Product Life Cycle Accounting and Reporting Standard. Retrieved April 1, 2016, from http://www.ghgprotocol.org/standards/product-standard

Grunert, K. G., Hieke, S., \& Wills, J. (2014). Sustainability labels on food products: consumer motivation, understanding and use. Food Policy, 44, 177-189. http://doi.org/10.1016/j.foodpol.2013.12.001

Guéneau, S., \& Carneiro, M. (2016). Evaluation of the FSC forest certification scheme in Brazil: a three level approach. In Agri-chains \& sustainable development. Montpellier.

Gupta, S., Rudd, J., \& Lee, N. (2014). Business sustainability through successful integration of marketing and operations. Industrial Marketing Management, 43(1), 3-5. http://doi.org/10.1016/j.indmarman.2013.10.004

Guzman, D. de. (2010). Bioplastic development increases with new applications. Retrieved January 3, 2017, from 
http://www.icis.com/resources/news/2010/10/25/9402443/bioplastic-developmentincreases-with-new-applications/

Hakansson, H., \& Ford, D. (2002). How should companies interact in business networks? Journal of Business Research, 55, 133-139. http://doi.org/10.1016/S01482963(00)00148-X

Ham, C. (2007). Green labelling: investigation into the marketing of FSC certified timber along the domestic timber value chain in South Africa. University of Stellenbosch.

Hamza, K. M., \& Dalmarco, D. de A. S. (2012). As Certificações Sustentáveis e Sua Relevância Para o Consumo Consciente e os Negócios. Reunir: Revista de Administração, Contabilidade E Sustentabilidade, 2, 1-20. http://doi.org/http://dx.doi.org/10.18696/reunir.v2i2.67

Hartikainen, H., Roininen, T., Katajajuuri, J. M., \& Pulkkinen, H. (2014). Finnish consumer perceptions of carbon footprints and carbon labelling of food products. Journal of Cleaner Production, 73(c), 285-293. http://doi.org/10.1016/j.jclepro.2013.09.018

Hartlieb, S., \& Jones, B. (2009). Humanising business through ethical labelling: Progress and paradoxes in the UK. Journal of Business Ethics, 88(3), 583-600. http://doi.org/10.1007/s10551-009-0125-x

Henion, K. E. (1972). The Effect of Ecologically Relevant Information on Detergent Sales. Journal of Marketing Research, 9(1), 10-14.

Hesse-Biber, S. N., \& Leavy, P. (2011). The practice of qualitative research (2nd editio). Thousand Oaks: Sage publications.

Hoekstra, A. Y., Chapagain, A. K., Aladaya, M. M., \& Mekonnen, M. M. (2011). Manual de Avaliação da Pegada Hídrica.

Holthaus, E. (2016). Our Planet's Temperature Just Reached a Terrifying Milestone. Retrieved March 15, 2016, from http://www.slate.com/blogs/future_tense/2016/03/01/february_2016_s_shocking_global_ warming_temperature_record.html

Horne, R. E. (2009). Limits to labels: The role of eco-labels in the assessment of product sustainability and routes to sustainable consumption. International Journal of Consumer Studies, 33(2), 175-182. http://doi.org/10.1111/j.1470-6431.2009.00752.x

Ideia Sustentável. (2010a). Dossiê - greenwashing no Brasil. Retrieved April 15, 2016, from http://www.ideiasustentavel.com.br/2010/10/greenwashing-no-brasil/

Ideia Sustentável. (2010b). Rótulos, selos e certificações verdes: uma ferramenta para o consumo consciente. Dossiê conhecimento para a sustentabilidade - 7.

Iles, A., \& Martin, A. N. (2013). Expanding bioplastics production: sustainable business innovation in the chemical industry. Journal of Cleaner Production, 45, 38-49. http://doi.org/10.1016/j.jclepro.2012.05.008

Intergovernmental Panel on Climate Change. (2014). Climate Change 2014 Synthesis Report Summary Chapter for Policymakers. Ipcc.

Iseal Alliance. (2010). The ISEAL 100. Retrieved from http://www.isealalliance.org/sites/default/files/ISEAL100.pdf

Iseal Alliance. (2016). Webinar: Top Trends in Sustainability Standards. Retrieved from http://www.isealalliance.org/online-community/resources/webinar-top-trends-insustainability-standards

Jaung, W., Putzel, L., Bull, G. Q., Guariguata, M. R., \& Sumaila, U. R. (2016). Estimating demand for certification of forest ecosystem services: A choice experiment with Forest Stewardship Council certificate holders. Ecosystem Services, 22(January), 193-201. http://doi.org/10.1016/j.ecoser.2016.10.016

Kangun, N., Carlson, L., \& Grove, S. J. (1991). Environmental advertising claims: a preliminary investigation. Journal of Public Policy \& Marketing, 10(2), 47-58. 
Kebker, V. W. (1943). Will grade labeling pay? The Journal of Marketing, 8(2), 185-188.

Kimberly-Clark. (2010). Relatório de Sustentabilidade.

Kimberly-Clark. (2011). Relatório de Sustentabilidade.

Kimberly-Clark. (2012). Relatório de Sustentabilidade.

Kimura, A., Wada, Y., Kamada, A., Masuda, T., Okamoto, M., Goto, S., ... Dan, I. (2010). Interactive effects of carbon footprint information and its accessibility on value and subjective qualities of food products. Appetite, 55(2), 271-278. http://doi.org/10.1016/j.appet.2010.06.013

Kohlrausch, A. K., Campos, L. M. de S., \& Selig, P. M. (2004). O comportamento do consumidor de produtos orgânicos em Florianópolis: uma abordagem estratégica. Revista Alcance, 11(1), 157-177.

Kruter, G. E., Barcellos, M. D. de, \& Silva, V. S. da. (2012). As atitudes dos consumidores em relação ao plástico verde. Revista de Gestão Ambiental E Sustentabilidade, 1(1), 1946. http://doi.org/10.5585/geas.v1i1.8

Lacy, P. (2013). It's complicated: consumers, companies and sustainability. Retrieved from http://www.theguardian.com/sustainable-business/complicated-consumers-companiessustainability

Laroche, M., Bergeron, J., \& Barbaro-Forleo, G. (2001). Targeting consumers who are willing to pay more for environmentally friendly products. Journal of Consumer Marketing, 18(6), 503-520. http://doi.org/10.1108/EUM0000000006155

Leire, C., \& Thidell, A. (2005). Product-related environmental information to guide consumer purchases - A review and analysis of research on perceptions, understanding and use among Nordic consumers. Journal of Cleaner Production, 13(10-11), 1061-1070. http://doi.org/10.1016/j.jclepro.2004.12.004

Loureiro, M. L., \& Lotade, J. (2005). Do fair trade and eco-labels in coffee wake up the consumer conscience? Ecological Economics, 53(1), 129-138. http://doi.org/10.1016/j.ecolecon.2004.11.002

Luchs, M., Walker Naylor, R., L. Rose, R., Jesse, R. C., Gau, R., Sommer, K., ... Weaver, T. (2011). Toward a sustainable marketplace: Expanding options and benefits for consumers. Journal of Research for Consumers, (19), 1-12.

Maimon, D. (1994). Eco-Estratégia nas Empresas Brasileiras : realidade ou discurso? RAE Revista de Administração Empresarial, 34(4), 119-130. http://doi.org/10.1590/S003475901994000400013

Maranzato, F. P. (2006). Tabela Ambiental : da concepção à evolução. Retrieved April 1, 2016, from http://inter.natura.net/Campus/arquivos/Tabela Ambiental_Felipe.pdf

Marconi, M. de A., \& Lakatos, E. M. (2005). Fundamentos da metodologia científica (6ed ed.). São Paulo: Atlas.

Market Analysis. (2016). Que selo é esse? Revista Do Idec, 25-27.

Marshall, C., \& Rossman, G. B. (2015). Designing qualitative research (6th ed.). Thousand Oaks: Sage publications.

Marshall, D., McCarthy, L., McGrath, P., \& Claudy, M. (2015). Going above and beyond: how sustainability culture and entrepreneurial orientation drive social sustainability supply chain practice adoption. Supply Chain Management: An International Journal, 20(4), 434-454. http://doi.org/10.1108/SCM-08-2014-0267

Mason, J. (2002). Qualitative researching (2nd ed.). Thousand Oaks: Sage Publications.

Mathiyazhagan, K., Govindan, K., NoorulHaq, A., \& Geng, Y. (2013). An ISM approach for the barrier analysis in implementing green supply chain management. Journal of Cleaner Production, 47, 283-297. http://doi.org/10.1016/j.jclepro.2012.10.042

McAllister, P. (2009). Assessing the valuation implications of the eco-labelling of commercial property assets. Journal of Retail and Leisure Property, 8(4), 311-322. 
http://doi.org/10.1057/rlp.2009.12

Miles, M. B., \& Huberman, A. M. (1984). Qualitative data analysis: a sourcebook of new methods. California: Sage Publications.

Mores, G. de V. (2013). Inovação e sustentabilidade na cadeia produtiva do plástico verde. Universidade Federal do Rio Grande do Sul.

Morris, J. (1997). Green goods? Consumers, product labels and the environment. London: IEA Environment Unit.

Morris, L. A., Hastak, M., \& Mazis, M. B. (1995). Consumer comprehension of environmental advertising and labeling claims. Journal of Consumer Affairs, 29(2), 328350.

Mossman, F. H. (1943). Grade labeling for canned fruits and vegetables. Journal of Marketing, 7(3), 241-244.

Muduli, K., Govindan, K., Barve, A., \& Geng, Y. (2013). Barriers to green supply chain management in Indian mining industries: A graph theoretic approach. Journal of Cleaner Production, 47, 335-344. http://doi.org/10.1016/j.jclepro.2012.10.030

Mülhaupt, R. (2013). Green polymer chemistry and bio-based plastics: dreams and reality. Macromolecular Chemistry and Physics, 214(2), 159-174. http://doi.org/10.1002/macp.201200439

Natura. (2010). Relatório Anual 2010.

Natura. (2011). Relatório Anual 2011.

Natura. (2015). Relatório Anual 2015.

Nebel, G., Quevedo, L., Bredahl Jacobsen, J., \& Helles, F. (2005). Development and economic significance of forest certification: The case of FSC in Bolivia. Forest Policy and Economics, 7(2), 175-186. http://doi.org/10.1016/S1389-9341(03)00030-3

Neff, J. (2010). Has Green Stopped Giving? Advertising Age, pp. 1-5.

Neutzling, D. M., \& Nascimento, L. F. (2015). Sustainability management in brazilian supply chains: a multiple case study. In XVIII Simpósio de Administração da Produção, Logística e Operações Internacionais (pp. 1-17).

Nilsson, H., Tunçer, B., \& Thidell, $\AA$. (2004). The use of eco-labeling like initiatives on food products to promote quality assurance - is there enough credibility? Journal of Cleaner Production, 12(5), 517-526. http://doi.org/10.1016/S0959-6526(03)00114-8

Nordic Ecolabelling. (2016). Nordic Ecolabelling. Retrieved April 13, 2016, from http://www.nordic-ecolabel.org/

Odebrecht. (2014). Plástico verde da Braskem chega às embalagens de pães integrais. Retrieved January 2, 2017, from http://www.odebrecht.com/pt$\mathrm{br} /$ comunicacao/releases/plastico-verde-da-braskem-chega-embalagens-de-paes-integrais

Orosk, F. D. A., Alves, F. C., \& Bomtempo, J. V. (2014). Bioplastics Tipping Point: drop-in or non-drop-in? Journal of Business Chemistry, 11(1), 43-50.

Orsiolli, T. A. E., \& Nobre, F. S. (2016). Empreendedorismo sustentável e stakeholders fornecedores: criação de valores para o desenvolvimento sustentável. $R A C, 20(4), 502-$ 523. http://doi.org/10.1590/1982-7849rac2016150031

Ottman, J. A., Stafford, E. R., \& Hartman, C. L. (2006). Avoiding green marketing myopia. Environment, 48(5), 11-15.

Overdevest, C., \& Rickenbach, M. G. (2006). Forest certification and institutional governance: An empirical study of forest stewardship council certificate holders in the United States. Forest Policy and Economics, 9(1), 93-102. http://doi.org/10.1016/j.forpol.2005.03.014

Parkinson, T. L. (1975). The Role of Seals and Certifications of Approval in Consumer Decision-Making. Journal of Consumer Affairs, 9, 1-13. http://doi.org/10.1111/j.17456606.1975.tb00545.x 
Patton, M. Q. (2002). Qualitative research and evaluation methods (3rd ed.). Thousand Oaks: Sage Publications.

Pedersen, E. R., \& Neergaard, P. (2006). Caveat Emptor - Let the buyer beware! Environmental labelling and the limitations of "Green" consumerism. Business Strategy and the Environment, 15(1), 15-29. http://doi.org/10.1002/bse.434

Perron, G. M. (2005). Barriers to Environmental Performance Improvements in Canadian SMEs. ... , Canada, (JANUARY 2005). Retrieved from http://ecoefficiency.management.dal.ca/Files/Research/Barriers_to_Environmental_Performance.p df

Pickett-Baker, J., \& Ozaki, R. (2008). Pro-environmental products: marketing influence on consumer purchase decision. Journal of Consumer Marketing, 25(5), 281-293. http://doi.org/10.1108/07363760810890516

Pinto, S. H. B., \& Granja, C. P. (2013). Análise Crítica Da Certificação Florestal BarsileiraCerflor E a Forest Stewardship Council- Fsc : Um Estudo De Múltiplos Casos. Análise Crítica Da Certificação Florestal Brasileira-CEFLOR E a Aorest Stewardship CouncilFSC: Um Estudo de Múltiplos Casos.

Piotrowski, R., \& Kratz, S. (2005). Eco-labelling in the Globalised Economy. In Challenges of globalization: new trends in international politics and society (pp. 217-37). New Jersey: Transaction Publishers.

Point-of-Purchase Advertising International - POPAI. (2014). The Power of Marketing at Retail. Retrieved March 15, 2016, from http://www.popai.com/industry-resources/thepower-of-marketing-at-retail-popai-textbook

Polonsky, M., Bailey, J., \& Baker, H. (1998). Communicating environmental information: are marketing claims on packaging misleading? Journal of Business Ethics, 17(3), 281-294. http://doi.org/10.1023/A:1005731914135

Pozzebon, M., \& Petrini, M. de C. (2013). Critérios para condução e avaliação de pesquisas qualitativas de natureza crítico-interpretativa. In A. R. W. Takahashi (Ed.), Pesquisa Qualitativa em Administração: fundamnetos, métodos e usos no Brasil. (pp. 51-72). São Paulo: Atlas.

Proteste. (2016a). Conar reitera punição à Bombril por esponja de aço se anunciar como "100\% ecológica." Retrieved December 10, 2016, from https://www.proteste.org.br/institucional/imprensa/press-release/2016/conar-reiterapunicao-a-bombril-por-esponja-de-aco-se-anunciar-como-100-ecologica

Proteste. (2016b). PROTESTE pede providências ao Conar sobre produtos que fazem maquiagem ambiental. Retrieved April 22, 2016, from https://www.proteste.org.br/institucional/imprensa/press-release/2016/proteste-pedeprovidencias-ao-conar-sobre-produtos-que-fazem-maquiagem-ambiental

Prothero, A. (1997). Communicating greener strategies: a study of "on pack" communication. Business Strategy and the Environment, 6, 74-82.

Prothero, A., Dobscha, S., Freund, J., Kilbourne, W. E., Luchs, M. G., Ozanne, J., \& Thøgersen, J. (2011). Sustainable Consumption: Opportunities for Consumer Research and Public Policy. Journal of Public Policy and Marketing, 30(1), 31-38. http://doi.org/10.1509/jppm.30.1.31

Rex, E., \& Baumann, H. (2007). Beyond ecolabels: what green marketing can learn from conventional marketing. Journal of Cleaner Production, 15(6), 567-576. http://doi.org/10.1016/j.jclepro.2006.05.013

Rickenbach, M., \& Overdevest, C. (2006). More than Markets : Assessing Forest Stewardship Council ( FSC ) Certification as a Policy Tool. Journal of Forestry, 104(May), 143-147.

Roberts, J. A. (1996). Green Consumer in the 1990: Profile and Implications for Advertising. Journal of Business Research, 36-3, 2963(95), 217-232. http://doi.org/10.1016/0148- 
2963(95)00150-6

Roberts, J. A., \& Bacon, D. R. (1997). Exploring the subtle relationships between environmental concern and ecologically conscious consumer behavior. Journal of Business Research, 40, 79-89. http://doi.org/10.1016/S0148-2963(96)00280-9

Rodrigues, D. B., Dalmarco, D. D. A. S., Aoqui, C., \& Marinho, B. de L. (2016). The meaning of the organic certification label for the consumer: a cluster analysis. REGE Revista de Gestão, 23(4), 316-325. http://doi.org/10.1016/j.rege.2016.08.001

Roger, S. (2015). Acordo do clima na COP-21 é sucesso ainda a ser confirmado. Retrieved March 15, 2016, from http://noticias.uol.com.br/internacional/ultimas-noticias/lemonde/2015/12/29/cop21-um-sucesso-ainda-a-ser-confirmado.htm

Rubik, F., Scheer, D., \& Iraldo, F. (2008). Eco-labelling and product development: Potentials and experiences. International Journal of Product Development, 6(3-4), 393-419. http://doi.org/10.1504/IJPD.2008.020401

Sarkis, J. (2003). A strategic decision framework for green supply chain management. Journal of Cleaner Production, 11(4), 397-409. http://doi.org/10.1016/S09596526(02)00062-8

Scammon, D., \& Mayer, R. (1995). Agency review of environmental marketing claims: caseby-case decomposition of the issues. Journal of Advertising, XXIV(2), 33-43. http://doi.org/10.1080/00913367.1995.10673474

Selltiz, C., Wrightsman, L. S., \& Cook, S. W. (1987). Métodos de pesquisa nas relações sociais (2nd ed.). São Paulo: EPU.

Seuring, S., \& Müller, M. (2008). From a literature review to a conceptual framework for sustainable supply chain management. Journal of Cleaner Production, 16(15), 16991710. http://doi.org/10.1016/j.jclepro.2008.04.020

Siggelkow, N. (2007). Persuasion with case studies. Academy of Management Journal, 50(1), 20-24. http://doi.org/10.5465/AMJ.2007.24160882

Silva, F. C., Shibao, F. Y., \& Santos, M. R. dos. (2016). Hierarquização das barreiras para implementação da gestão da cadeia de suprimentos verde na visão de um fornecedor da indústria automotiva brasileira. In Simpósio de Administração da Produção, Logística e Operações Internacionais.

Sønderskov, K. M., \& Daugbjerg, C. (2011). The state and consumer confidence in ecolabeling: organic labeling in Denmark, Sweden, The United Kingdom and The United States. Agriculture and Human Values, 28(4), 507-517. http://doi.org/10.1007/s10460010-9295-5

Srivastava, S. K. (2007). Green supply-chain management: A state-of-the-art literature review. International Journal of Management Reviews, 9(1), 53-80. http://doi.org/10.1111/j.1468-2370.2007.00202.x

Stern, P. C. (1999). Information, Incentives, and Proenvironmental Consumer Behavior. Journal of Consumer Policy, 22, 461-479. http://doi.org/10.1023/A:1006211709570

SustainAbility. (2011). Signed, Sealed ... Delivered? Behind Certifications and Beyond Labels.

TerraChoice. (2010). The Sins of Greenwashing - Home and Family Edition. Underwriters Laboratories, 1-31.

The Blue Angel. (2016). The Blue Angel Environmental Label Jury. Retrieved April 13, 2016, from https://www.blauer-engel.de/en

Thøgersen, J. (2000). Psychological determinants of paying attention to eco-labels in purchase decisions: Model development and multinational validation. Journal of Consumer Policy, 23(3), 285-313. http://doi.org/10.1023/A:1007122319675

Thøgersen, J. (2005). How May Consumer Policy Empower Consumers for Sustainable Lifestyles? Journal of Consumer Policy, 28(2), 143-177. http://doi.org/10.1007/s10603- 
005-2982-8

Thøgersen, J., Haugaard, P., \& Olesen, A. (2010). Consumer responses to ecolabels. European Journal of Marketing, 44(11/12), 1787-1810. http://doi.org/10.1108/03090561011079882

Thun, J.-H., \& Müller, A. (2010). An empirical analysis of green supply chain management in the German automotive industry. Business Strategy and the Environment, 19(January 2009), 119-132. http://doi.org/10.1002/bse

Timberland. (2016). Timberland Greenindex. Retrieved March 1, 2016, from http://greenindex.timberland.com/

Tsoulfas, G. T., \& Pappis, C. P. (2006). Environmental principles applicable to supply chains design and operation. Journal of Cleaner Production, 14(18), 1593-1602. http://doi.org/10.1016/j.jclepro.2005.05.021

UL Environment. (2016). The sins of greenwashing. Retrieved April 18, 2016, from http://sinsofgreenwashing.com/index.html

UN Global Compact, \& Accenture. (2013). The UN Global Compact-Accenture CEO Study on Sustainability - Architects of a Better World. UN Global Compact Reports.

United Nations [UN]. (1992). United Nations Conference on Environment \& Development Agenda 21.

United Nations Environmental Programme - UNEP. (2015a). Product sustainability information.

United Nations Environmental Programme - UNEP. (2015b). Sustainable consumption and production - a handbook for policymakers.

Upham, P., Dendler, L., \& Bleda, M. (2011). Carbon labelling of grocery products: Public perceptions and potential emissions reductions. Journal of Cleaner Production, 19(4), 348-355. http://doi.org/10.1016/j.jclepro.2010.05.014

US Environmental Protection Agency - EPA. (1998). Environmental Labeling Issues, Policies, and Practices Worldwide. Retrieved July 8, 2015, from http://www2.epa.gov/sites/production/files/2015-09/documents/wwlabel3.pdf

Van Amstel, M., Driessen, P., \& Glasbergen, P. (2008). Eco-labeling and information asymmetry: a comparison of five eco-labels in the Netherlands. Journal of Cleaner Production, 16(3), 263-276. http://doi.org/10.1016/j.jclepro.2006.07.039

Vark, C. van. (2016). Behind the label: can we trust certification to give us fairer products? Retrieved October 11, 2016, from https://www.theguardian.com/sustainablebusiness/2016/mar/10/fairtrade-labels-certification-rainforest-alliance

Vilchez, V. F., Darnall, N., \& Correa, J. A. A. (2016). Stakeholder influences on the design of firms' environmental practices. Journal of Cleaner Production. http://doi.org/10.1016/j.jclepro.2016.10.129

Walker, H., \& Jones, N. (2012). Sustainable supply chain management across the UK private sector. Supply Chain Management: An International Journal, 17(1), 15-28. http://doi.org/10.1108/13598541211212177

Wander, A. E., Lacerda, A. C. V., Freitas, F. C. De, Didonet, A. D., \& Didonet, C. C. G. M. (2007). Alimentos orgânicos - Oportunidades de mercado e desafios. Revista de Política Agrícola, 2, 44-55.

Webster, Jr., F. E. (1975). Determining the Characteristics of the Socially Conscious Consumer. Journal of Consumer Research, 2(3), 188. http://doi.org/10.1086/208631

Wolford, E. J. (2015). Biopolymers in packaging — some hurdles, but strong signs of growth. Retrieved January 2, 2017, from http://www.packworld.com/sustainability/bioplastics/biopolymers-packaging-somehurdles-strong-signs-growth

WRI, W. R. I.-, \& Ecolabel Index. (2010). Global Ecolabel Monitor. 
Yin, R. K. (1994). Case study research: design and methods (2nd ed.). Thousand Oaks: Sage Publications.

Zaabi, S. Al, Dhaheri, N. Al, \& Diabat, A. (2013). Analysis of interaction between the barriers for the implementation of sustainable supply chain management. International Journal of Advanced Manufacturing Technology, 68(1-4), 895-905. http://doi.org/10.1007/s00170-013-4951-8

Zabkar, V., \& Hosta, M. (2013). Willingness to act and environmentally conscious consumer behaviour: Can prosocial status perceptions help overcome the gap? International Journal of Consumer Studies, 37(3), 257-264. http://doi.org/10.1111/j.14706431.2012.01134.x

Zambanini, M. E., Bresciani, L. P., Pereira, R. da S., Souza, D. A., \& Ortega, G. (2014). Sustentabilidade e inovacão: um estudo sobre o plástico verde. Revista Em Agronegócios E Meio Ambiente, 7(2), 429-452.

Zhu, Q., Sarkis, J., \& Geng, Y. (2005). Green supply chain management in China: pressures, practices and performance. International Journal of Operations \& Production Management, 25(5), 449-468. http://doi.org/10.1108/01443570510593148 


\section{APÊNDICES}

Apêndice A - sites das certificações listadas nos tópicos 2.1.1 e 2.1.5

Apêndice B - e-mail convite para participação na pesquisa

Apêndice $\mathbf{C}$ - termo de consentimento informado

Apêndice D - roteiro de entrevista: empresa B2C que não adota certificações

Apêndice E - roteiro de entrevista: empresa B2C que adota certificações

Apêndice F - roteiro de entrevista: empresa B2B

Apêndice G - roteiro de entrevista: FSC

Apêndice $\mathbf{H}$ - roteiro de entrevista: Imaflora

Apêndice I - roteiro de entrevista: Braskem 


\section{APÊNDICE A - Sites das certificações}

Sites dos selos internacionais:

http://www.blauer-engel.de/en/index.php

http://www.ecologo.org/en/

http://www.ecomark.jp/english/

http://www.greenseal.org/

http://www.svanen.se/en/

http://ec.europa.eu/environment/ecolabel/

\section{Sites das instituições internacionais:}

http://www.carbontrust.com/certification

http://www.c2ccertified.org

http://www.earthisland.org

http://www.ecocert.com

http://www.fairtrade.net

http://www.fsc.org.br

http://www.friendofthesea.org

http://www.certifiedhumanebrasil.org

http://www.certifiedhumane.org

http://www.ibd.com.br

http://www.maff.go.jp/e/policies/standard/jas/index.html

http://www.usgbc.org

http://www.msc.org

http://www.pefc.org

http://www.rainforest-alliance.org

http://www.responsiblesoy.org

http://www.rspo.org

http://www.ethicalbiotrade.org

http://www.unesco.org

http://www.usda.gov

\section{Sites das instituições nacionais:}

http://www.abicalcados.com.br

http://www.assintecal.org.br

http://www.abnt.org.br

http://www.anc.org.br

http://www.fadc.org.br

http://www.braskem.com

http://www.eletrobras.gov.br

http://www.gruposustentax.com.br

http://www.ibd.com.br

http://www.ibdn.org.br

http://www.institutochaovivo.com.br

http://www.ifbauer.org.br

http://www.institutolife.org 
http://www.inmetro.gov.br

http://www.institutototum.com.br

http://www.sosma.org.br

http://www.maxambiental.com.br

http://www.agricultura.gov.br

http://www.petrobras.com

http://www.suframa.gov.br

http://www.fucapi.br

Sites das organizações responsáveis pelos selos:

http://www.bombril.com.br

http://www.cocacolabrasil.com.br

http://www.dupont.com.br

http://www.ehcosmeticos.com.br

http:// www.bimbobrasil.com.br

http://www.kimberly-clark.com.br

http://www.natura.com.br 


\section{APÊNDICE B - E-mail convite para participação na pesquisa}

Olá!

Meu nome é Denise de Abreu Sofiatti Dalmarco e eu faço mestrado em Administração de Empresas na Faculdade de Economia, Administração e Contabilidade da Universidade de São Paulo (FEA/USP). Minha pesquisa final do curso tem como tema as certificações sustentáveis - mais especificamente os selos FSC e I'm Green, e meu objetivo é analisar os entraves para utilização de insumos sustentáveis certificados, sob a ótica dos gestores envolvidos nesse processo.

Peguei seu contato com meu colega XXXX (Explicar indicação de nome).

Gostaria de conversar com alguém da empresa envolvido com as certificações sustentáveis para compreender melhor qual o posicionamento institucional da mesma a respeito do tema. Você conseguiria me indicar alguém que possa me ajudar, por favor?

A entrevista seria realizada pessoalmente, com duração aproximada de 1 hora.

A princípio, gostaria de divulgar o nome e empresa dos entrevistados, mas caso prefiram fazer sua contribuição de forma sigilosa, seriam revelados apenas o cargo do respondente e segmento de atuação da empresa.

Aguardo seu retorno e, desde já, agradeço a atenção dispensada!

Um abraço,

Denise Sofiatti Dalmarco

Obs.: se quiser conhecer um pouco mais sobre meu currículo acadêmico, você pode acessar o site do CNPq: http://lattes.cnpq.br/4748505562516873 


\section{APÊNDICE C - Termo de consentimento informado}

Antes de tomar a decisão sobre sua colaboração, não hesite em fazer todas as perguntas que julgar necessárias.

Declaro, por meio deste termo, que concordei em participar da entrevista para a pesquisa da mestranda em Administração Denise de Abreu Sofiatti Dalmarco, aluna da Faculdade de Economia, Administração e Contabilidade da Universidade de São Paulo (FEA/USP), cujo objetivo é levantar as vantagens e os entraves na utilização de insumos sustentáveis certificados, sob a ótica dos gestores envolvidos nesse processo.

Eu sei que posso me recusar a responder uma ou outra das questões, se eu assim decidir. Entendo também que eu posso pedir o cancelamento da entrevista, o que anulará o meu aceite de participação e proibirá o pesquisador de utilizar as informações obtidas comigo até então.

A fim de ser transcrita literalmente, autorizo o uso do gravador e o uso dos dados transmitidos em sua totalidade, incluindo meu nome e empresa em que atuo, ciente de que a transcrição da entrevista será enviada para mim para aprovação antes da utilização dos dados pela pesquisadora e de que todas as informações serão utilizadas apenas pela pesquisadora, a fim de cumprir com o objetivo dessa pesquisa, e para fins acadêmicos.

Fui informado que a pesquisa é orientada pelos Professores Doutores Andres Rodriguez Veloso (veloso@usp.br) e Kavita Miadaira Hamza (kavita@usp.br), a quem poderei contatar, se achar necessário.

Afirmo que aceitei participar voluntariamente, sem receber incentivo financeiro, a fim de colaborar com o sucesso desta pesquisa acadêmica.

\section{Participação na entrevista}

\begin{tabular}{|l|l|}
\hline Entrevistado & Entrevistador \\
\hline Nome: & Nome: Denise Sofiatti Dalmarco \\
CPF: & CPF: $109.821 .018-21$ \\
Assinatura: & Assinatura: \\
\hline Local: & Data: \\
\hline
\end{tabular}


APÊNDICE D - Roteiro de entrevista: empresa B2C que não adota as certificações

UNIVERSIDADE DE SÃO PAULO

Faculdade de Economia, Administração e Contabilidade

Departamento de Administração

Pós-Graduação

\section{ROTEIRO ENTREVISTA}

Boa tarde,

Obrigada por aceitar o convite para participar desta pesquisa.

Meu nome é Denise Sofiatti Dalmarco, e eu faço mestrado em Administração na Faculdade de Economia, Administração e Contabilidade da Universidade de São Paulo (FEA/USP)

Meu objetivo é analisar as vantagens e os entraves na utilização de insumos sustentáveis certificados, com foco nos insumos com selos FSC e I'm Green (polietileno verde), sob a ótica dos diversos stakeholders envolvidos nesse processo.

Para que eu possa acompanhar toda a sua manifestação, sem perder qualquer parte, pediria licença para gravar a entrevista, a fim de que posteriormente eu possa transcrevê-la na íntegra e, junto com as demais que estarei realizando, traçar o panorama objetivado nesse estudo. A entrevista transcrita lhe será enviada para que possa ser assegurada a fidedignidade da transcrição.

Se possível, gostaria de contar com sua autorização para publicar seu nome, cargo e empresa em que atua, com o objetivo de conferir maior credibilidade para os dados levantados. Caso você prefira fazer sua contribuição de forma sigilosa, serão revelados apenas seu cargo e setor da empresa/instituição em que atua.

(entregar termo de consentimento de entrevista) 


\section{Caracterização do entrevistado (caso aceite divulgação)}

1. Nome:

2. Cargo:

3. Principais responsabilidades:

4. Tempo de empresa:

5. Formação:

\section{Caracterização da empresa e ambiente de negócios}

6. Atuação:

7. Ano de criação da empresa:

8. País de origem:

9. Ano de início da operação no Brasil (caso multinacional):

10. Número de marcas no Brasil:

11. Número de funcionários no Brasil:

12. Faturamento bruto da empresa no Brasil:

13. Missão:

14. Principais concorrentes:

15. Número de produtos disponíveis no Brasil:

16. A empresa tem política de sustentabilidade?

17. Política de produtos - embalagens:

\section{Certificações sustentáveis}

Agora vamos falar sobre as certificações sustentáveis.

18. Gostaria de começar a entrevista pedindo que você me conte o que conhece sobre certificações sustentáveis

> (Caso entrevistado não conheça nada, fazer breve explicação)

19. Você já ouviu falar sobre o assunto? Qual sua opinião a respeito?

20. Em sua opinião, quais os objetivos das certificações sustentáveis? Quais benefícios e vieses elas podem oferecer ao seu negócio?

21. Algumas pesquisas mostram que os produtos certificados, além de beneficiar o meio ambiente e determinados grupos sociais, também agrega valor à empresa, perante seus clientes. No entanto, outros estudos mostram que ainda são poucas as empresas que utilizam tais selos. Por que você acha que isso acontece?

22. Você conhece alguma certificação sustentável? Qual? O que ela significa?

23. Você já considerou usar alguma certificação sustentável em sua linha de produtos, ou em algum produto específico? 
> Caso positivo para P22:

24. Qual? Como foi o processo de análise da certificação? Como ficou sabendo sobre a certificação? Você foi abordado por alguma empresa?

>> Caso negativo para P22:

25. Se não considerou, quais as principais razões?

\section{Cerificação FSC}

26. Você conhece o selo FSC? Já o viu? Sabe o que ele significa?

>> Caso positivo para $\mathrm{P} 22$ :

27. Você em algum momento considerou adotar o selo FSC nas embalagens de sua linha de produtos?

>> Caso positivo para P23:

28. Quais motivações a levaram a considerar adotar o selo FSC? Que diferenciais ele oferece?

29. Como foi este processo? Por que não deu certo? Quanto tempo levou para se chegar à definição pela não adoção do selo? (explorar barreiras)

30. Quais profissionais e áreas da empresa foram envolvidos nesta definição? Vocês envolveram algum fornecedor? Qual foi o posicionamento dele?

31. Você pretende tentar adotar o selo novamente? Por que?

\section{>> Caso negativo para P23:}

32. Quais motivos levaram você a nunca considerar utilizar o selo FSC nas embalagens de sua linha de produtos? (explorar barreiras)

33. Em sua opinião, que diferenciais o selo FSC poderia oferecer aos seus produtos? (se houver)

34. Supondo que um dia você decida adotar o selo FSC, quais profissionais e áreas da empresa deveriam ser envolvidos nesta definição? E fornecedores?

35. Que tipo de informação você acha que seria necessária para suportar esta decisão?

36. Que mudanças internas você acha que deveriam ser feitas para que obter tal aprovação?

37. Quanto tempo você acha que levaria para se chegar a uma definição pela implementação ou não do selo?

\section{> Caso negativo para P22:}

(explicar o que é selo, mostrar produto com o mesmo)

38. Em sua opinião, quais seriam os motivos para o seu não conhecimento deste selo?

39. Você acha que usar este selo em suas embalagens poderia oferecer algum diferencial para a sua linha de produtos? Por que? 
40. Supondo que um dia você decida adotar o selo FSC, quais profissionais e áreas da empresa deveriam ser envolvidos nesta definição? E fornecedores?

41. Que tipo de informação você acha que seria necessária para suportar esta decisão?

42. Quanto tempo você acha que levaria para se chegar a uma definição pela implementação ou não do selo?

\section{I'm Green}

Agora vamos falar sobre o selo I'm Green

43. Você conhece o selo I'm Green? Já o viu? Sabe o que ele significa?

> Caso positivo para P38:

44. Você em algum momento considerou adotar o selo I'm Green nas embalagens de sua linha de produtos?

> Caso positivo para P39:

45. Quais motivações a levaram a considerar adotar o selo I'm Green? Que diferenciais ele oferece?

46. Como foi este processo? Por que não deu certo? Quanto tempo levou para se chegar à definição pela não adoção do selo? (explorar barreiras)

47. Quais profissionais e áreas da empresa foram envolvidos nesta definição? Vocês envolveram algum fornecedor? Qual foi o posicionamento dele?

48. Você gostaria de tentar adotar o selo novamente?

\section{>> Caso negativo para P39:}

49. Quais motivos levaram você a nunca considerar utilizar o selo I'm Green nas embalagens de sua linha de produtos? (explorar barreiras)

50. Em sua opinião, que diferenciais o selo I'm Green poderia oferecer aos seus produtos? (se houver)

51. Supondo que um dia você decida adotar o selo I'm Green, quais profissionais e áreas da empresa deveriam ser envolvidos nesta definição? E fornecedores?

52. Que tipo de informação você acha que seria necessária para suportar esta decisão?

53. Que mudanças internas você acha que deveriam ser feitas para que obter tal aprovação?

54. Quanto tempo você acha que levaria para se chegar a uma definição pela implementação ou não do selo?

>> Caso negativo para P38:

(explicar o que é selo, mostrar produto com o mesmo)

55. Em sua opinião, quais seriam os motivos para o seu não conhecimento deste selo?

56. Você acha que usar este selo em suas embalagens poderia oferecer algum diferencial para a sua linha de produtos? Por que? 
57. Supondo que um dia você decida adotar o selo I'm Green, quais profissionais e áreas da empresa deveriam ser envolvidos nesta definição? E fornecedores?

58. Que tipo de informação você acha que seria necessária para suportar esta decisão?

59. Quanto tempo você acha que levaria para se chegar a uma definição pela implementação ou não do selo?

\section{Geral}

60. Em sua opinião, como os consumidores finais enxergam os produtos com uma certificação sustentável? Você acredita que os consumidores levam esses selos em consideração no momento da compra? Por quê? Há um nicho de mercado (de consumidores) para estes selos? Se sim, quem seriam?

61. Você acha que estes selos são considerados de maneiras diferentes dependendo da categoria de produtos em que são utilizados? Quais categorias você acha que seriam mais aderentes à proposta de utilização destas certificações?

62. Pensando em relação a tendências de mercado, você acredita que estas certificações podem ser mais demandadas pelos consumidores no futuro?

63. Em sua opinião, de quem é a responsabilidade por uma maior divulgação das certificações sustentáveis? Certificadora? Produtor da embalagem? Fabricante do produto final? Varejista? Mídia em geral?

64. Além das certificações mencionadas (FSC e I'm Green), a empresa utiliza alguma outra?

65. Se sim, qual?

66. Se não, você acha que existem outras que poderiam ser utilizadas em suas linhas de produtos? Quais?

67. Você gostaria de adicionar mais algum comentário?

68. Você poderia me indicar fornecedores da empresa para realização de entrevista?

Muito obrigada pela sua participação. Quando a pesquisa for finalizada, enviarei uma cópia para que você tenha acesso aos resultados alcançados. 
APÊNDICE E - Roteiro de entrevista: empresa B2C que adota certificações

UNIVERSIDADE DE SÃO PAULO

Faculdade de Economia, Administração e Contabilidade

Departamento de Administração

Pós-Graduação

\section{ROTEIRO ENTREVISTA}

Boa tarde,

Obrigada por aceitar o convite para participar desta pesquisa.

Meu nome é Denise Sofiatti Dalmarco, e eu faço mestrado em Administração na Faculdade de Economia, Administração e Contabilidade da Universidade de São Paulo (FEA/USP)

Meu objetivo é analisar as vantagens e os entraves na utilização de insumos sustentáveis certificados, com foco nos insumos com selos FSC e I'm Green (polietileno verde), sob a ótica dos diversos stakeholders envolvidos nesse processo.

Para que eu possa acompanhar toda a sua manifestação, sem perder qualquer parte, pediria licença para gravar a entrevista, a fim de que posteriormente eu possa transcrevê-la na íntegra e, junto com as demais que estarei realizando, traçar o panorama objetivado nesse estudo. A entrevista transcrita lhe será enviada para que possa ser assegurada a fidedignidade da transcrição.

Se possível, gostaria de contar com sua autorização para publicar seu nome, cargo e empresa em que atua, com o objetivo de conferir maior credibilidade para os dados levantados. Caso você prefira fazer sua contribuição de forma sigilosa, serão revelados apenas seu cargo e setor da empresa/instituição em que atua.

(entregar termo de consentimento de entrevista) 


\section{Caracterização do entrevistado (caso aceite divulgação)}

1. Nome:

2. Cargo:

3. Principais responsabilidades:

4. Tempo de empresa:

5. Formação:

\section{Caracterização da empresa e ambiente de negócios}

6. Atuação:

7. Ano de criação da empresa:

8. País de origem:

9. Ano de início da operação no Brasil (caso multinacional):

10. Número de marcas no Brasil:

11. Número de funcionários no Brasil:

12. Faturamento bruto da empresa no Brasil:

13. Missão:

14. Principais concorrentes:

15. Número de produtos disponíveis no Brasil:

16. A empresa tem política de sustentabilidade?

17. Política de produtos - embalagens:

\section{Certificações sustentáveis}

Agora vamos falar sobre as certificações sustentáveis.

18. Gostaria de começar a entrevista pedindo que você me conte o que conhece sobre certificações sustentáveis

19. Em sua opinião, quais os objetivos das certificações sustentáveis? Quais benefícios e vieses elas podem oferecer ao seu negócio?

20. Algumas pesquisas mostram que os produtos certificados, além de beneficiar o meio ambiente e determinados grupos sociais, também agrega valor à empresa, perante seus clientes. No entanto, outros estudos mostram que ainda são poucas as empresas que utilizam tais selos. Por que você acha que isso acontece?

21. Quais certificações sustentáveis você conhece? O que elas significam?

\section{Cerificação FSC}

Agora vamos falar sobre a certificação FSC. 
22. Você se lembra como foi que conheceram a certificação FSC? O que ela significa? Vocês avaliaram outras certificações similares? (buscar compreender que área ou pessoa foi a responsável por trazer a ideia da implementação do selo)

23. Quais motivações levaram a empresa a adotar a certificação FSC? Que diferenciais ele oferece?

24. Como foi o processo de adoção do selo FSC nas linhas de produtos? Quando ele se iniciou? Quanto tempo levou para que a empresa pudesse utilizar os cartuchos certificados? Qual o custo envolvido nessa operação? E o prazo para retorno desse investimento?

25. Quais profissionais e áreas da empresa foram envolvidos nesta implementação?

26. Como foi a negociação com os fornecedores para que utilizassem o novo insumo? Vocês tiveram contato direto com a FSC ou com as certificadoras? (explorar dificuldades internas, área que liderou "projeto", dificuldades técnicas, relação com stakeholders envolvidos)

27. Quais impactos (tanto positivos quanto negativos) o uso do selo FSC trouxe para a empresa? (checar custos e viabilidade técnica)

28. Quantos produtos da empresa utilizam o selo FSC hoje? Por que alguns produtos carregam o selo e outros não? Há planos de expansão da utilização deste insumo?

29. Em sua opinião, os consumidores sabem o que o selo significa?

\section{I'm Green}

Agora vamos falar sobre o selo I'm Green

30. Você se lembra como foi que conheceram o PE Verde da Braskem? O que ele significa? Vocês avaliaram outras certificações similares? (buscar compreender que área ou pessoa foi a responsável por trazer a ideia da implementação do selo)

31. Quais motivações a levaram a adotar o PE verde? Que diferenciais ele oferece?

32. Como foi o processo de adoção do PE verde na linha de produtos da Natura? Quando ele se iniciou? Quanto tempo levou para que a Natura pudesse utilizar este insumo? Qual o custo envolvido nessa operação? E o prazo para retorno desse investimento?

33. Quais profissionais e áreas da empresa foram envolvidos nesta implementação? (explorar dificuldades internas, área que liderou "projeto", dificuldades técnicas)

34. Como foi a negociação com os fornecedores para que utilizassem o novo insumo? Vocês tiveram contato direto com a Braskem? (relação com stakeholders envolvidos)

35. Quais impactos (tanto positivos quanto negativos) o uso do PE verde trouxe para o negócio? (checar custos e viabilidade técnica)

36. Quantos produtos da empresa utilizam o PE verde hoje? Há planos de expansão da utilização deste insumo?

37. O que você acha do selo I'm Green? Ele agrega valor ao produto? Os consumidores sabem o que ele significa?

38. Por que a Natura adotou um logotipo próprio nas embalagens que usam o plástico verde? Qual vantagem de ter um selo exclusivo? Vocês continuam usando este selo? Sabe dizer qual foi a receptividade dos consumidores para o selo? 


\section{Geral}

30. Em sua opinião, como os consumidores finais enxergam os produtos com uma certificação sustentável? Você acredita que os consumidores levam esses selos em consideração no momento da compra? Por quê? Há um nicho de mercado (de consumidores) para estes selos? Se sim, quem seriam?

31. Você acha que estes selos são considerados de maneiras diferentes dependendo da categoria de produtos em que são utilizados? Quais categorias você acha que seriam mais aderentes à proposta de utilização destas certificações?

32. Pensando em relação a tendências de mercado, você acredita que estas certificações podem ser mais demandadas pelos consumidores no futuro?

33. Em sua opinião, de quem é a responsabilidade por uma maior divulgação das certificações sustentáveis? Certificadora? Produtor da embalagem? Fabricante do produto final? Varejista? Mídia em geral?

34. Além das certificações mencionadas (FSC e I'm Green), a empresa utiliza alguma outra?

35. Se sim, qual?

36. Se não, você acha que existem outras que poderiam ser utilizadas em suas linhas de produtos? Quais?

37. Você gostaria de adicionar mais algum comentário?

38. Você poderia me indicar fornecedores da empresa para realização de entrevista?

Muito obrigada pela sua participação. Quando a pesquisa for finalizada, enviarei uma cópia para que você tenha acesso aos resultados alcançados. 
APÊNDICE F - Roteiro de entrevista: empresa B2B

UNIVERSIDADE DE SÃO PAULO

Faculdade de Economia, Administração e Contabilidade

Departamento de Administração

Pós-Graduação

\section{ROTEIRO ENTREVISTA}

Boa tarde,

Obrigada por aceitar o convite para participar desta pesquisa.

Meu nome é Denise Sofiatti Dalmarco, e eu faço mestrado em Administração na Faculdade de Economia, Administração e Contabilidade da Universidade de São Paulo (FEA/USP)

Meu objetivo é analisar as vantagens e os entraves na utilização de insumos sustentáveis certificados, com foco nos insumos com selos FSC e I'm Green (polietileno verde), sob a ótica dos diversos stakeholders envolvidos nesse processo.

Para que eu possa acompanhar toda a sua manifestação, sem perder qualquer parte, pediria licença para gravar a entrevista, a fim de que posteriormente eu possa transcrevê-la na íntegra e, junto com as demais que estarei realizando, traçar o panorama objetivado nesse estudo. A entrevista transcrita lhe será enviada para que possa ser assegurada a fidedignidade da transcrição.

Se possível, gostaria de contar com sua autorização para publicar seu nome, cargo e empresa em que atua, com o objetivo de conferir maior credibilidade para os dados levantados. Caso você prefira fazer sua contribuição de forma sigilosa, serão revelados apenas seu cargo e setor da empresa/instituição em que atua.

(entregar termo de consentimento de entrevista) 


\section{Caracterização do entrevistado (caso aceite divulgação)}

1. Nome:

2. Cargo:

3. Principais responsabilidades:

4. Tempo de empresa:

5. Formação:

\section{Caracterização da empresa e ambiente de negócios}

6. Atuação:

7. Ano de criação da empresa:

8. País de origem:

9. Ano de início da operação no Brasil (caso multinacional):

10. Número de marcas no Brasil:

11. Número de funcionários no Brasil:

12. Faturamento bruto da empresa no Brasil:

13. Missão:

14. Principais concorrentes:

15. Número de produtos disponíveis no Brasil:

16. A empresa tem política de sustentabilidade?

17. Política de produtos - embalagens:

\section{Certificações sustentáveis}

Agora vamos falar sobre as certificações sustentáveis.

18. Gostaria de começar a entrevista pedindo que você me conte o que conhece sobre certificações sustentáveis

>> (Caso entrevistado não conheça nada, fazer breve explicação)

19. Você já ouviu falar sobre o assunto? Qual sua opinião a respeito?

20. Em sua opinião, quais os objetivos das certificações sustentáveis? Quais benefícios e vieses elas podem oferecer ao seu negócio?

21. Algumas pesquisas mostram que os produtos certificados, além de beneficiar o meio ambiente e determinados grupos sociais, também agrega valor à empresa, perante seus clientes. No entanto, outros estudos mostram que ainda são poucas as empresas que utilizam tais selos. Por que você acha que isso acontece? 


\section{Cerificação FSC}

22. Você se lembra como foi que conheceram o selo FSC? O que ele significa? Vocês avaliaram outras certificações similares? (buscar compreender que área ou pessoa foi a responsável por trazer a ideia da implementação do selo)

23. Quais motivações levaram a empresa a adotar o selo FSC nas embalagens que produz? Que diferenciais ele oferece?

24. Como foi o processo de adoção do selo FSC? Quando ele se iniciou? Quanto tempo levou para que a empresa pudesse utilizar o selo? Qual o custo envolvido nessa operação? E o prazo para retorno desse investimento?

25. Quais profissionais e áreas da empresa foram envolvidos nesta implementação? Vocês tiveram contato direto com a certificadora e/ou com o escritório do FSC no Brasil? (explorar dificuldades internas, área que liderou "projeto", dificuldades técnicas, relação com stakeholders envolvidos)

26. Quais impactos (tanto positivos quanto negativos) o uso da certificação FSC trouxe (ou você espera que trará) para o seu negócio?

27. Os produtos com selo FSC são mais caros que os das demais linhas? Poderia mencionar quanto?

28. Quais os principais benefícios que os seus clientes veem na utilização dos produtos com selo FSC?

29. E o que os seus clientes costumam usar de justificativa para a não utilização de produtos com o selo FSC?

30. Qual o \% de clientes de vocês que compram embalagens certificadas? E em termos de faturamento? Em sua opinião, como está a tendência do uso das certificações FSC entre seus clientes e potenciais clientes?

31. Vocês sempre oferecem os produtos com selo FSC para os clientes?

\section{I'm Green}

32. Você se lembra como foi que conheceram o PE Verde da Braskem? O que ele significa? Vocês avaliaram outros insumos similares? (buscar compreender que área ou pessoa foi a responsável por trazer a ideia da implementação do selo)

33. Quais motivações a levaram a adotar o PE verde? Que diferenciais ele oferece?

34. Como foi o processo de adoção do PE verde na empresa? Quando ele se iniciou? Quanto tempo levou para que pudessem utilizar este insumo? Qual o custo envolvido nessa operação? E o prazo para retorno desse investimento?

35. Quais profissionais e áreas da empresa foram envolvidos nesta implementação? (explorar dificuldades internas, área que liderou "projeto", dificuldades técnicas)

36. Como foi a negociação com o fornecedor deste novo insumo? (relação com stakeholders envolvidos)

37. Quais impactos (tanto positivos quanto negativos) o uso do PE verde trouxe para o negócio? (checar custos e viabilidade técnica)

38. Quantos clientes da empresa utilizam o PE verde hoje? Há planos de expansão dessa carteira? Vocês sempre oferecem os produtos com PE verde para os clientes? E como 
está a tendência do uso do PE verde (aumento ou queda), entre seus clientes e potenciais clientes?

39. Os produtos com PE verde são mais caros que os similares com plástico de petróleo? Poderia mencionar quanto?

40. Quais os principais benefícios que os seus clientes veem na utilização de produtos com PE verde?

41. E o que os seus clientes costumam usar de justificativa para a não utilização dos PE verde?

42. O que você acha do selo I'm Green? Ele agrega valor ao produto? Os consumidores sabem o que ele significa?

\section{Geral}

43. Em sua opinião, como os consumidores finais enxergam os produtos com uma certificação sustentável? Você acredita que os consumidores levam esses selos em consideração no momento da compra? Por quê? Há um nicho de mercado (de consumidores) para estes selos? Se sim, quem seriam?

44. Você acha que estes selos são considerados de maneiras diferentes dependendo da categoria de produtos em que são utilizados? Quais categorias você acha que seriam mais aderentes à proposta de utilização destas certificações?

45. Pensando em relação a tendências de mercado, você acredita que estas certificações podem ser mais demandadas pelos consumidores no futuro?

46. Em sua opinião, de quem é a responsabilidade por uma maior divulgação das certificações sustentáveis? Certificadora? Produtor da embalagem? Fabricante do produto final? Varejista? Mídia em geral?

47. Além das certificações mencionadas (FSC e I'm Green), a empresa utiliza alguma outra?

48. Se sim, qual?

49. Se não, você acha que existem outras que poderiam ser utilizadas em suas linhas de produtos? Quais?

50. Você gostaria de adicionar mais algum comentário?

51. Você poderia me indicar fornecedores da empresa para realização de entrevista?

Muito obrigada pela sua participação. Quando a pesquisa for finalizada, enviarei uma cópia para que você tenha acesso aos resultados alcançados. 
APÊNDICE G - Roteiro de entrevista: FSC

UNIVERSIDADE DE SÃO PAULO

Faculdade de Economia, Administração e Contabilidade

Departamento de Administração

Pós-Graduação

\section{ROTEIRO ENTREVISTA - FSC}

Boa tarde,

Obrigada por aceitar o convite para participar desta pesquisa.

Meu nome é Denise Sofiatti Dalmarco, e eu faço mestrado em Administração na Faculdade de Economia, Administração e Contabilidade da Universidade de São Paulo (FEA/USP)

Meu objetivo é analisar as vantagens e os entraves na utilização de insumos sustentáveis certificados, com foco nos insumos com selos FSC e I'm Green (polietileno verde), sob a ótica dos diversos stakeholders envolvidos nesse processo.

Para que eu possa acompanhar toda a sua manifestação, sem perder qualquer parte, pediria licença para gravar a entrevista, a fim de que posteriormente eu possa transcrevê-la na íntegra e, junto com as demais que estarei realizando, traçar o panorama objetivado nesse estudo. A entrevista transcrita lhe será enviada para que possa ser assegurada a fidedignidade da transcrição.

Se possível, gostaria de contar com sua autorização para publicar seu nome, cargo e empresa em que atua, com o objetivo de conferir maior credibilidade para os dados levantados. Caso você prefira fazer sua contribuição de forma sigilosa, serão revelados apenas seu cargo e setor da empresa/instituição em que atua.

(entregar termo de consentimento de entrevista) 


\section{Caracterização do entrevistado (caso aceite divulgação)}

1. Nome:

2. Cargo:

3. Principais responsabilidades:

4. Tempo de empresa:

5. Formação:

\section{Caracterização da empresa e ambiente de negócios}

6. Atuação:

7. Ano de criação da instituição:

8. País de origem:

9. Ano de início da operação no Brasil (caso multinacional):

10. Número de funcionários no Brasil:

11. Faturamento no Brasil:

12. Missão:

13. Principais concorrentes:

\section{Certificações sustentáveis}

Agora vamos falar sobre as certificações sustentáveis de uma forma geral

14. Gostaria de começar a entrevista pedindo que você me fale sua opinião sobre certificações sustentáveis de uma forma geral

15. Em sua opinião, quais os objetivos das certificações sustentáveis? Quais benefícios e vieses elas podem oferecer aos negócios?

16. Que outras certificações sustentáveis você conhece? O que elas significam?

17. Qual sua opinião em relação à quantidade de selos/certificações existentes hoje?

18. Qual sua opinião em relação à quantidade de empresas que utilizam os selos sustentáveis? São poucas? Muitas? Por que você acha que isso acontece?

19. Em sua opinião, como os consumidores finais enxergam os produtos com uma certificação sustentável? Você acredita que os consumidores levam esses selos em consideração no momento da compra? Por quê?

20. Você acha que estes selos são considerados de maneiras diferentes dependendo da categoria de produtos em que são utilizados? Quais categorias você acha que seriam mais aderentes à proposta de utilização destas certificações?

21. Pensando em relação a tendências de mercado, você acredita que estas certificações podem ser mais demandadas pelos consumidores no futuro? 


\section{FSC}

39. Que diferenciais o selo FSC oferece a empresas quem o adotam? Quais os principais benefícios que ele gera ao negócio?

(Qual retorno eles recebem em relação à receptividade do material certificado pelos consumidores?)

40. O selo FSC é um dos mais conhecidos mundialmente, e também no Brasil. Por que?

41. Como é feita a divulgação do selo FSC? Que canais de comunicação são utilizados pela organização?

42. Em sua opinião, de quem é a responsabilidade por uma maior divulgação do selo FSC? Da própria organização? Das certificadoras? Produtores de embalagem? Fabricantes de produto final? Varejistas? Mídia em geral?

43. Há uma agência de comunicação contratada pela organização no Brasil? Vocês tem flexibilidade para desenvolver ações locais ou devem seguir sempre diretrizes globais?

44. No plano estratégico 2015-2020 há um objetivo de ampliar reconhecimento da marca e do conceito FSC em todos os elos da cadeia produtiva florestal até o consumidor final. Isso não era um objetivo até então?

45. Existe uma área voltada para prospecção de novos "clientes" do FSC? Isso é responsabilidade de quem? Há algum tipo de interação com as certificadoras a fim de gerar mais certificações?

46. O FSC não tem área de Marketing. Alguém da equipe é responsável por fazer análise de mercado dos selos de manejo florestal e/ou de certificações como um todo? Se não houver responsável por isso, acha que seria interessante ter esse tipo de profissional na organização?

47. Poderia comentar sobre os perfis de consumidores que são o target de comunicação da organização: Green Indeed e Glamour Green. Quais outros perfis existem?

48. Há controle para checar se empresas estão usando selo de forma ilegal?

\section{Cadeia de custódia}

49. Em geral, quanto tempo demora para que uma empresa obtenha a certificação FSC cadeia de custódia? Vocês tem alguma influência nesse processo?

50. Saberia dizer quais as principais justificativas utilizadas pelas empresas de bens de consumo que não adotam o selo FSC? Quais as principais barreiras para utilização de insumos com certificado FSC? Como elas geralmente são contornadas??

51. O custo de um papel certificado é mais caro do que um sem certificação? Vocês tem algum controle sobre isso?

52. As empresas que obtem o selo geralmente renovam sua certificação anualmente? Vocês monitoram o turnover das empresas com selo? Conseguem levantar os motivos para a não renovação?

53. Como está a tendência do uso das certificações FSC no Brasil? 


\section{Relação com stakeholders}

54. Como é a relação do FSC com as certificadoras?

55. Como é a relação do FSC com as empresas (B2B e B2C)?

56. O FSC tem algum tipo de contato com as empresas que são certificadas ou somente com as certificadoras?

57. Como é a relação do FSC com outros donos de selos?

58. Como é a relação do FSC com o governo?

59. Como é a relação do FSC com o consumidor final?

60. Como é a relação do FSC com ONGs ambientalistas?

61. O FSC é um membro do ISEAL Alliance. Que benefícios isso traz para sua atuação? Qual o papel dessa organização? Como ela apoia as certificadoras?

62. E o GEN? Vocês também fazem parte desta organização?

\section{Geral}

63. Você gostaria de adicionar mais algum comentário?

Muito obrigada pela sua participação. Quando a pesquisa for finalizada, enviarei uma cópia para que você tenha acesso aos resultados alcançados. 
APÊNDICE H - Roteiro de entrevista: Imaflora

UNIVERSIDADE DE SÃO PAULO

Faculdade de Economia, Administração e Contabilidade

Departamento de Administração

Pós-Graduação

\section{ROTEIRO ENTREVISTA - IMAFLORA}

Boa tarde,

Obrigada por aceitar o convite para participar desta pesquisa.

Meu nome é Denise Sofiatti Dalmarco, e eu faço mestrado em Administração na Faculdade de Economia, Administração e Contabilidade da Universidade de São Paulo (FEA/USP)

Meu objetivo é analisar as vantagens e os entraves na utilização de insumos sustentáveis certificados, com foco nos insumos com selos FSC e I'm Green (polietileno verde), sob a ótica dos diversos stakeholders envolvidos nesse processo.

Para que eu possa acompanhar toda a sua manifestação, sem perder qualquer parte, pediria licença para gravar a entrevista, a fim de que posteriormente eu possa transcrevê-la na íntegra e, junto com as demais que estarei realizando, traçar o panorama objetivado nesse estudo. A entrevista transcrita lhe será enviada para que possa ser assegurada a fidedignidade da transcrição.

Se possível, gostaria de contar com sua autorização para publicar seu nome, cargo e empresa em que atua, com o objetivo de conferir maior credibilidade para os dados levantados. Caso você prefira fazer sua contribuição de forma sigilosa, serão revelados apenas seu cargo e setor da empresa/instituição em que atua.

(entregar termo de consentimento de entrevista) 


\section{Caracterização do entrevistado (caso aceite divulgação)}

1. Nome:

2. Cargo:

3. Principais responsabilidades:

4. Tempo de empresa:

5. Formação:

\section{Caracterização da empresa e ambiente de negócios}

6. Atuação:

7. Ano de criação da instituição:

8. País de origem:

9. Ano de início da operação no Brasil (caso multinacional):

10. Número de funcionários no Brasil:

11. Faturamento no Brasil:

12. Missão:

13. Principais concorrentes:

\section{Certificações sustentáveis}

Agora vamos falar sobre as certificações sustentáveis de uma forma geral

14. Gostaria de começar a entrevista pedindo que você me fale sua opinião sobre certificações sustentáveis de uma forma geral

15. Em sua opinião, quais os objetivos das certificações sustentáveis? Quais benefícios e vieses elas podem oferecer aos negócios?

16. Que outras certificações sustentáveis você conhece? O que elas significam?

17. Qual sua opinião em relação à quantidade de selos/certificações existentes hoje?

18. Qual sua opinião em relação à quantidade de empresas que utilizam os selos sustentáveis? São poucas? Muitas? Por que você acha que isso acontece?

19. Em sua opinião, como os consumidores finais enxergam os produtos com uma certificação sustentável? Você acredita que os consumidores levam esses selos em consideração no momento da compra? Por quê?

20. Você acha que estes selos são considerados de maneiras diferentes dependendo da categoria de produtos em que são utilizados? Quais categorias você acha que seriam mais aderentes à proposta de utilização destas certificações?

21. Pensando em relação a tendências de mercado, você acredita que estas certificações podem ser mais demandadas pelos consumidores no futuro? 


\section{FSC (foco em bens de consumo, não na madeira)}

22. Quais os principais benefícios que os seus clientes veem na utilização de produtos com selo FSC? Qual retorno eles recebem em relação à receptividade do material certificado pelos consumidores? Que diferenciais ele oferece?

23. O selo FSC é um dos mais conhecidos mundialmente, e também no Brasil. Por que?

24. Você saberia me dizer como é feita a divulgação do selo FSC? Que canais de comunicação são utilizados pela organização?

25. Em sua opinião, de quem é a responsabilidade por uma maior divulgação do selo FSC? Da própria organização? Das certificadoras? Produtores de embalagem? Fabricantes de produto final? Varejistas? Mídia em geral?

26. Como está a tendência do uso das certificações FSC no Brasil?

\section{Gestão Imaflora}

27. Como é realizado o processo de certificação de cadeia de custódia, desde o início até a empresa estar liberada para usar o selo? Quanto tempo demora? As empresas já iniciam o processo de forma mais organizada para receber a auditoria, ou há muito retrabalho?

28. Que áreas das empresas são normalmente envolvidas num processo de certificação de cadeia de custódia? Com quem vocês tem contato?

29. Existe uma área voltada para prospecção de novos "clientes"? Isso é responsabilidade de quem? Qual responsabilidade da área comercial? Como vocês buscam aumentar o seu impacto?

30. O Imaflora tem uma área de Marketing? Costuma fazer pesquisas de mercado? Alguém da equipe é responsável por fazer análise de mercado dos selos de manejo florestal e/ou de certificações como um todo? Se não houver responsável por isso, acha que seria interessante ter esse tipo de profissional na organização?

31. Existe uma equipe de comunicação no Imaflora - quais são suas atribuições?

32. Como é a relação do Imaflora com as empresas que obtém a certificação? Há uma manutenção da relação após a certificação? De que forma?

33. As empresas geralmente renovam sua certificação anualmente? Vocês monitoram o turnover das empresas com selo? Conseguem levantar os motivos para a não renovação?

34. Há controle para checar se empresas estão usando selo de forma ilegal?

35. Quais as principais justificativas utilizadas pelas empresas de bens de consumo que não adotam o selo FSC? Quais as principais barreiras para utilização de insumos com certificado FSC? Em sua opinião, como essas barreiras poderiam ser contornadas?

36. Em sua opinião, o custo da certificação impede que empresas pequenas tenham acesso ao selo FSC? (fundo social)

37. O custo de um papel certificado é mais caro do que um sem certificação? Vocês tem algum controle sobre isso?

38. Toda certificação gera um selo? Porque algumas empresas fazem a certificação mas não usam o selo? 


\section{Relação com stakeholders}

39. Como é a relação do Imaflora com o FSC?

40. Como é a relação do Imaflora com outros donos de selos? (fairtrade, friend of the sea, life $\mathrm{BR})$

41. Como é a relação do Imaflora com outras certificadoras?

42. Como é a relação do Imaflora com o governo?

43. Como é a relação do Imaflora com as empresas (B2B e B2C)?

44. Como é a relação do Imaflora com o consumidor final?

45. Como é a relação do Imaflora com ONGs ambientalistas?

\section{Geral}

46. Você gostaria de adicionar mais algum comentário?

Muito obrigada pela sua participação. Quando a pesquisa for finalizada, enviarei uma cópia para que você tenha acesso aos resultados alcançados. 
APÊNDICE I - Roteiro de entrevista: Braskem

UNIVERSIDADE DE SÃO PAULO

Faculdade de Economia, Administração e Contabilidade

Departamento de Administração

Pós-Graduação

\section{ROTEIRO ENTREVISTA - BRASKEM}

Olá!

Obrigada por aceitar o convite para participar desta pesquisa.

Meu nome é Denise Sofiatti Dalmarco, e eu faço mestrado em Administração na Faculdade de Economia, Administração e Contabilidade da Universidade de São Paulo (FEA/USP)

Meu objetivo é analisar as vantagens e os entraves na utilização de insumos sustentáveis certificados, com foco nos insumos com selos FSC e I'm Green (polietileno verde), sob a ótica dos diversos stakeholders envolvidos nesse processo.

Para que eu possa acompanhar toda a sua manifestação, sem perder qualquer parte, pediria licença para gravar a entrevista, a fim de que posteriormente eu possa transcrevê-la na íntegra e, junto com as demais que estarei realizando, traçar o panorama objetivado nesse estudo. A entrevista transcrita lhe será enviada para que possa ser assegurada a fidedignidade da transcrição.

Se possível, gostaria de contar com sua autorização para publicar seu nome, cargo e empresa em que atua, com o objetivo de conferir maior credibilidade para os dados levantados.

(entregar termo de consentimento de entrevista) 


\section{Caracterização do entrevistado (caso aceite divulgação)}

1. Nome:

2. Cargo:

3. Principais responsabilidades:

4. Tempo de empresa:

5. Formação:

\section{Caracterização da empresa e ambiente de negócios}

6. Atuação:

7. Ano de criação da empresa:

8. País de origem:

9. Ano de início da operação no Brasil (caso multinacional):

10. Número de marcas no Brasil:

11. Número de funcionários no Brasil:

12. Faturamento bruto da empresa no Brasil:

13. Missão:

14. Principais concorrentes:

15. Número de produtos disponíveis no Brasil:

16. A empresa tem política de sustentabilidade?

17. Política de produtos - embalagens:

\section{Certificações sustentáveis}

Agora vamos falar sobre as certificações sustentáveis de uma forma geral

18. Gostaria de começar a entrevista pedindo que você me conte o que conhece sobre certificações sustentáveis e sua opinião a respeito do tema

19. Em sua opinião, quais os objetivos das certificações sustentáveis? Quais benefícios e vieses elas podem oferecer ao seu negócio?

20. Quais certificações sustentáveis você conhece? O que elas significam?

21. Qual sua opinião em relação à quantidade de empresas que utilizam as certificações sustentáveis? São poucas? Muitas? Por que você acha que isso acontece?

22. Em sua opinião, como os consumidores finais enxergam os produtos com uma certificação sustentável? Você acredita que os consumidores levam esses selos em consideração no momento da compra? Por quê? Há um nicho de mercado (de consumidores) para estes selos? Se sim, qual seria?

23. Você acha que estes selos são considerados de maneiras diferentes dependendo da categoria de produtos em que são utilizados? Quais categorias você acha que seriam mais aderentes à proposta de utilização destas certificações? 
24. Pensando em relação a tendências de mercado, você acredita que estas certificações podem ser mais demandadas pelos consumidores no futuro

25. Em sua opinião, de quem é a responsabilidade por uma maior divulgação das certificações sustentáveis? Certificadora? Produtor da embalagem? Fabricante do produto final? Varejista? Mídia em geral?

\section{PE VERDE}

26. Ano de lançamento do produto:

27. Ano de lançamento em escala industrial e do selo I'm Green:

28. Investimento:

29. Atuação:

30. Principais clientes:

31. Quais foram as primeiras empresas que utilizaram o PE Verde? Como foi feita a oferta do insumo a essas empresas e como foi a aceitação do mesmo?

32. Em geral, quanto tempo demora para que uma empresa consiga utilizar o PE verde em sua linha de produtos? Que áreas são envolvidas nesta implementação? Como é o processo de mudança para o novo insumo?

33. Quais os principais benefícios que os seus clientes veem na utilização de produtos com $\mathrm{PE}$ verde? Qual retorno eles tem recebido em relação à receptividade do novo material pelos consumidores?

34. E o que os seus clientes costumam usar de justificativa para a não utilização dos PE verde? Quais as principais barreiras enfrentadas na utilização deste material por parte das empresas?

35. Em algumas entrevistas realizadas durante minha pesquisa, algumas pessoas relataram o alto custo do insumo como uma barreira para sua utilização. Apesar de mencionarem que o custo já caiu um pouco desde o lançamento, dizem que ainda é muito mais alto que o PE normal. Por que o preço é mais alto? É apenas uma questão de volume, ou o custo deste insumo sempre será mais caro que seu similar não-renovável?

36. Outro ponto levantado se refere a dúvidas sobre capacidade produtiva em atender altas demandas. Como está a utilização da capacidade produtiva da fábrica do PE verde? Vocês ainda conseguem atender um alto volume de produção, caso a demanda aumente?

37. Uma última barreira listada é relacionada ao risco de o insumo ser fornecido por apenas uma empresa. Como vocês poderiam contornar essa questão?

38. Quais ações de marketing e/ou comerciais são desenvolvidas pela empresa a fim de divulgar o PE verde e prospectar novos clientes? Qual principal público-alvo de vocês? Convertedores, Indústrias, Varejo e/ou Governo (compras públicas)

39. Dentro das empresas, quais são as áreas procuradas para apresentar o produto?

40. São feitas ações de divulgação para consumidores finais e/ou para entidades de classe? (públicos que não são compradores diretos mas que podem ter alguma influencia na demanda)

41. E a divulgação do selo I'm Green? Existe um plano de marketing para fazer com que seja mais conhecido e valorizado pelos consumidores? São ações separadas? 
42. Como está a tendência do uso do PE verde no Brasil? E no exterior?

43. Quanto o PE verde representa no total das venda de PE da Braskem?

44. O volume de vendas de PE verde hoje é maior no Brasil ou no exterior? Quanto o Brasil representa no total de vendas? A marca I’m Green já é reconhecida na europa também?

\section{SELO I'M GREEN}

Objetivo do selo I'm Green: criar valor e identificar todos os seus polímeros produzidos a partir de matérias-primas renováveis. O selo foi construído para ser simples e direto na comunicação com os diversos públicos e concebido para proporcionar aos clientes mais valor ao seu produto.

"Com a criação do selo estamos estendendo os benefícios da aplicação de uma resina de fonte renovável para o consumidor final".

O desenvolvimento do selo, que é auto referenciável e não apresenta barreiras culturais, vem para realçar a identidade de produtos que têm em sua essência a relação com a natureza, além de transferir valor para a marca e para o consumidor que busca inserir, em seu dia a dia, a prática do consumo sustentável.

(informações obtidas no site da empresa)

45. Há pesquisa de mercado para avaliar se os consumidores e demais stakeholders reconhecem o selo I'm Green? O fato de estar em inglês não poderia comprometer a aceitação do mesmo pelos consumidores brasileiros? Vocês chegaram a avaliar a utilização do termo em português?

\section{Finalização}

46. Você gostaria de adicionar mais algum comentário?

Muito obrigada pela sua participação. Quando a pesquisa for finalizada, enviarei uma cópia para que você tenha acesso aos resultados alcançados. 